\title{
Treatment of haemophilia and its complications
}

Citation for published version (APA):

Santagostino, E. (2000). Treatment of haemophilia and its complications: a focus on safety aspects.

[Doctoral Thesis, Maastricht University]. Universiteit Maastricht. https://doi.org/10.26481/dis.20001110es

Document status and date:

Published: 01/01/2000

DOI:

10.26481/dis.20001110es

Document Version:

Publisher's PDF, also known as Version of record

\section{Please check the document version of this publication:}

- A submitted manuscript is the version of the article upon submission and before peer-review. There can be important differences between the submitted version and the official published version of record.

People interested in the research are advised to contact the author for the final version of the publication, or visit the DOI to the publisher's website.

- The final author version and the galley proof are versions of the publication after peer review.

- The final published version features the final layout of the paper including the volume, issue and page numbers.

Link to publication

\footnotetext{
General rights rights.

- You may freely distribute the URL identifying the publication in the public portal. please follow below link for the End User Agreement:

www.umlib.nl/taverne-license

Take down policy

If you believe that this document breaches copyright please contact us at:

repository@maastrichtuniversity.nl

providing details and we will investigate your claim.
}

Copyright and moral rights for the publications made accessible in the public portal are retained by the authors and/or other copyright owners and it is a condition of accessing publications that users recognise and abide by the legal requirements associated with these

- Users may download and print one copy of any publication from the public portal for the purpose of private study or research.

- You may not further distribute the material or use it for any profit-making activity or commercial gain

If the publication is distributed under the terms of Article $25 \mathrm{fa}$ of the Dutch Copyright Act, indicated by the "Taverne" license above, 


\section{Treatment of haemophilia and its complications. A focus on safety aspects}

Elena Santagostino

FOR EVERY ACTION THERE IS AN EQUAL AND OPPOSITE REACTION (NEWTON'S THIRD LAW OF MOTION) 
Elena Santagostino

\section{Treatment of haemophilia and its complications. A focus on safety aspects}

ISBN: 88-87052-07-7

Cover: Tibetan hanging painting, XII century (detail). 


\section{Treatment of haemophilia and its complications. A focus on safety aspects}

PROEFSCHRIFT

ter verkrijging van de graad van doctor aan de

Universiteit Maastricht op gezag van de

Rector Magnificus, Prof. Dr. A.C. Nieuwenhuijzen Kruseman, volgens het besluit van het College van Decanen, in het openbaar te verdedigen op

vrijdag 10 november 2000 om 10.00 uur

door

Elena Santagostino

Geboren op 08 juni 1962 te Milaan 
Promotores:

Prof. Dr. H.C. Hemker

Prof. Dr. P.M. Mannucci (University of Milan)

Beoordelingscommissie:

Dr. K. Hamulyak (voorzitter)

Prof. Dr. R. Donckerwolcke

Dr. P. Giangrande (Churchill Hospital, Oxford)

Prof. Dr. A. Gringeri (Maggiore Hospital, Milan)

Prof. Dr. W.Th. Hermens

This thesis has been prepared at Angelo Bianchi Bonomi Hemophilia and Thrombosis Center, IRCCS Ospedale Maggiore, University of Milan, Italy.

Financial support by Istituto Sierovaccinogeno Italiano - ISI S.p.A., Castelvecchio Pascoli (Lu), Italy, for the publication of this thesis is gratefully acknowledged. 


\title{
Chapter 1
}

General introduction

\section{Chapter 2}

\section{Treatment of chronic hepatitis $\mathrm{C}$ and its complications}

M.G.Rumi, E.Santagostino, M.Morfini, A.Gringeri, G.Tagariello, A.Chistolini, P.Pontisso, A.Tagger, M.Colombo, P.M.Mannucci and the Hepatitis Study Group of the Association of Italian Hemophilia Centers. A multicenter controlled, randomized, open trial of interferon $\alpha 2 b$ treatment of anti-human immunodeficiency virus-negative hemophilic patients with chronic hepatitis $\mathrm{C}$. Blood 89: 3529-3533, 1997.

E. Santagostino, M. Colombo, D. Cultraro, M. Muça-Perja, A. Gringeri, P.M. Mannucci. High prevalence of serum cryoglobulins in multitransfused hemophilic patients with chronic hepatitis $\mathrm{C}$. Blood 92: $516-5 / 9,1998$.

\section{Chapter 3}

\section{HIV infection in hemophiliacs}

E.Santagostino, A.Gringeri, D.Cultraro, F.Tradati, L.Siracusano, A.Marinoni, P.M.Mannucci. Factors associated with progression to AIDS and mortality in a cohort of HIV-infected patients with hemophilia followed up since seroconversion. Cellular and Molecular Biology 41: 371-380,1995.

E.Vicenzi, P.Bagnarelli, E.Santagostino, S.Ghezzi, M.Alfano, M.S.Sinnone, G.Fabio, L.Turchetto, G.Moretti, A.Lazzarin, A.Mantovani, P.M.Mannucci, M.Clementi, A.Gringeri, G.Poli. Hemophilia and nonprogressing human immunodeficiency virus type 1 infection. Blood 89: 191-200, 1997.

D. Zagury, A. Lachgar, V. Chams, L.S. Fall, J. Bernard, J.F. Zagury, B. Bizzini, A. Gringeri, E. Santagostino, J. Rappaport, M. Feldman, S.J. O’Brien, A. Burny, R.C. Gallo. C-C chemokines, pivotal in protection against HIV type 1 infection.

Proceeding of the National Academy of Sciences USA 95: 3857-3861, 1998.

\section{Chapter 4}

Non-lipid enveloped viruses: transmission by factor concentrates

\author{
E.Santagostino, P.M.Mannucci, A.Gringeri, A.Azzi, M.Morfini, \\ R.Russo, R.Santoro, M.Schiavoni. \\ Transmission of parvovirus B19 by coagulation factor concentrates exposed \\ to $100^{\circ} \mathrm{C}$ heat after lyophilization. \\ Transfusion 37: 517-522, 1997
}




\section{Chapter 5 \\ Development of inhibitors}

E.Santagostino, A.Gringeri, L.Tagliavacca, P.M.Mannucci.

Inhibitors to factor VIII in a family with mild hemophilia:

molecular characterization and response to factor VIII and desmopressin.

Thrombosis and Hacmostasis 74: 619.621. 1995.

page 104

C.R.M. Hay, C.A. Ludlam, B.T. Colvin, F.G.H. Hill, F.E. Preston, N. Wasseem,

R. Bagnall, I.R. Peake, E. Berntorp, E.P. Mauser Bunschoten, K. Fijnvandraat,

C.K. Kasper, G. White, E. Santagostino.

Factor VIII inhibitors in mild and moderate-severity haemophilia A.

Thrombosis and Hacmostasis 79: 762-766. 1998.

C.R.M.Hay, J.N.Lozier, C.A.Lee, M.Laffan, F.Tradati, E.Santagostino,

N.Ciavarella, M.Schiavoni, H.Fukui, A. Yoshioka, J.Teitel, P.M.Mannucci, C.K.Kasper.

Safety profile of porcine factor VIII and its use as hospital and home-therapy

for patients with hemophilia A and inhibitors: the results of an international survey.

Thrombosis and Haemostasis 75: 25-29, 1996.

E. Santagostino, A. Gringeri, P.M. Mannucci.

Home treatment with recombinant activated factor VII in patients with

factor VIII inhibitors: the advantages of early intervention.

British Journal of Haematology 104: 22-26, 1999.

page 1.36

\section{Chapter 6}

Summary and prospectives

ACKNOWLEDGEMENTS

page 151

Curriculum Vitae 


\section{Chapter 1}

General Introduction 


\section{Hemophilia and replacement treatment}

Hemophilia $A$ and hemophilia $B$ are the most severe and the most important congenital disorders of blood coagulation. Hemophilia $A$ is the commonest of the inherited bleeding diseases that affects one in 10.000 males and hemophilia $B$ cases are about 1/5-1/6 of hemophilia A cases (1). Both are inherited as X-linked recessive conditions. The severity of bleeding is related to the nature of the underlying gene mutation that is responsible for the deficiency of factor VIII coagulant activity in hemophilia A or of FIX coagulant activity in hemophilia B. Severely affected patients with low factor VIII or IX levels in plasma $(<1-2 \mathrm{IU} / \mathrm{dl})$ tend to bleed frequently and spontaneously into joints and muscles. It is not possible to distinguish hemophilia A from hemophilia B clinically. In both conditions bleeding manifestations may occur at various sites and after surgery, but, the most prominent feature is repeated haemarthrosis leading to the chronic arthropathy that represents the major cause of morbidity in hemophiliacs.

Coagulation factor replacement has been the cornerstone of hemophilia management and has resulted in a dramatic increase in both the longevity of patients and their quality of life $(2,3)$. The evolution of therapeutic materials available for hemophilia treatment started with the introduction of cryoprecipitate in 1964, which led to plasma being superseded by coagulation factor concentrates during the 1970 s. Replacement treatment was fostered by the availability of these lyophilized concentrates derived from pooled donations of thousand of donors but, on the other hand, these therapeutic preparations were responsible for the transmission of viral infections to a large proportion of patients.

\section{Hepatitis $\mathrm{C}$ virus infection}

Before the introduction of virucidal methods in 1985 practically all patients with hemophilia developed non-A non-B hepatitis after the first infusion of concentrate $(4,5)$. Since identification of the hepatitis $C$ virus (HCV) as the principal cause of non-A non-B hepatitis, all of them have been recognized to be positive for anti HCVantibody (6-8).

With stored sera it was possible to detect retrospectively anti-HCV seroconversion after the infusion of non-virus inactivated concentrate and to follow the events in acute HCV infection in hemophiliacs. The median time to seroconversion was 11 weeks (9) and the median time to development of hepatitis was only 4 weeks. This shorter incubation period of hepatitis $\mathrm{C}$ in hemophiliacs compared to the period in recipients of blood transfusion probably reflects the greater inoculum in pooled concentrates than in single units of blood. Assuming that each patient became infected at the time of the first concentrate infusion, the duration of hepatitis $C$ can be precisely 
established in hemophiliacs. For this reason, the study of the natural history of HCV infection in this cohort has provided interesting data on the progression of liver disease and on the long-term complications.

Only approximately $20 \%$ of patients eliminate the virus after acute infection, with loss of detectable HCV-RNA from the blood and liver $(10,11)$, all the remaining hemophiliacs are at risk of developing chronic hepatitis.

Initial clinical studies appeared to indicate that post-transfusion hepatitis in hemophilic patients would not result in serious illness (12). It is now clear that hemophiliacs evaluated at that time had probably been infected only a few years before and were in the early stages of the natural history of chronic infection. During the following decades histological studies (13-15) have shown evidence of chronic active hepatitis or cirrhosis in about $10-20 \%$ of hemophiliacs, with poor correlation between serum transaminase levels and histological findings. In a UK cohort, the risk of hepatic decompensation 20 years after the first exposure was estimated to be $10.8 \%$ (16). In a study carried out in UK hemophiliacs the mortality rate from liver disease was 16.7 times that of the general population and the mortality rate from liver cancer 5.6 times (17).

In a large, international survey of multitransfused hemophiliacs the crude rate of hepatocellular carcinoma was 30 times the background incidence of the tumor in the countries of origin of the patients and it was invariably associated with the presence of cirrhosis (18). It was also observed that even annual ultrasound and alpha fetoprotein screening was not sufficiently sensitive to pick up early signs of malignancy (19).

$\mathrm{HCV}$ is classified into six major genotypes (20) with regional and ethnic variations in distribution. The HCV genotypes in hemophilic patients correspond to those of the infected donations used to manufacture concentrates or cryoprecipitate. A comprehensive study of $\mathrm{HCV}$ genotype distribution in hemophiliacs showed that the majority of patients were infected with type 1 (64\%), type $3(19 \%)$ and type 2 (12\%), which predominate in North America and Northern Europe (21). The HCV genotype is of clinical importance in the management of hemophiliacs because significantly more patients with type $1 \mathrm{HCV}$ infection progress to hepatic decompensation, with higher serum HCV-RNA levels and a poorer response to interferon than patients with type $3 \mathrm{HCV}$ infection (21).

Recently, persistent HCV infection has been associated with a number of extrahepatic conditions, such as arthritis, glomerulonephritis, keratoconjunctivitis sicca, porphyria cutanea tarda, cryoglobulinemia and B-cell non-Hodgkin lymphoma (2224). Long-term prospective surveillance is needed to better define the clinical importance of these HCV-related disorders in hemophiliacs. 


\section{Hepatitis $B$ virus infection and coinfection by multiple hepatotropic viruses}

The majority of intensively treated older hemophiliacs have serological evidence of previous hepatitis $\mathrm{B}$ virus (HBV) infection. A few patients have become chronic carriers of $\mathrm{HBsAg}$ and the prevalence of this condition amongst severe hemophiliacs in developed countries is now $<3 \%(15,16)$. HBV transmission has largely been stopped by the introduction of virucidal methods into the concentrate manufacturing process, but hepatitis $B$ vaccination is still recommended for hemophiliacs $(25,26)$. In addition, HBV vaccination confers protection against hepatitis D virus (HDV), which requires the presence of $\mathrm{HBV}$ for its own replication. Hemophiliacs with HDV infection appear to have rapidly progressive liver disease (27).

A peculiar feature of liver disease in hemophiliacs is that its course may be influenced by multiple virus infections. Coinfection with hepatotropic viruses may lead to complex interactions and has the potential to complicate the diagnosis and management of chronic hepatitis in these patients. Some data suggest that active HCV replication may suppress HBV (28), supporting the existence of viral interference between HCV and HBV in hemophiliacs. Therefore, detailed virological and serological evaluation is needed during and after antiviral treatment of hepatitis $C$ in patients with HBV coinfection to monitor for possible reactivation of $\mathrm{HBV}$ replication.

Virus inactivation procedures have also been successful in reducing the risk of transmitting the blood-borne hepatitis $\mathrm{G}$ virus ( $\mathrm{HGV}$ ) and the reported prevalence of anti-HGV seropositivity in hemophiliacs is about $15 \%(29,30)$. The HGV hepatitis resolved in most cases and caused chronic viremia in only a small number of patients, without biochemical evidence of persistent liver damage (30).

\section{Human immunodeficiency virus (HIV) infection}

The acquired immunodeficiency syndrome (AIDS) has been devastating in the hemophilic population. The first example of transfusion-induced AIDS was diagnosed in a patient with hemophilia who died of Pneumocystis carinii pneumonia in 1982 (31). In early 1985, when reliable tests for HIV antibodies became available, the prevalence of HIV seropositivity among severe hemophiliacs in USA was found to range between $60 \%$ and $90 \%(32-34)$. Serial stored serum samples from a large number of hemophiliacs made it possible to estimate the seroconversion date in this high risk population with reasonable precision. The majority of seroconversions occurred in 1981-1982, but several were detected in sera from as early as 1979 and a few were observed world wide in sera from 1986, whereas no new seroconversions have been reported in hemophiliacs since 1986, following the introduction of heat- 
treated concentrates in 1985 (35). Although hemophiliacs have been exposed to HIV for a limited period of time, their life expectancy has significantly changed. In the UK the death rate in HIV-infected hemophiliacs rose steeply from $8 / 1,000$ in 1985 1992 to $81 / 1,000$ in 1991-1992 (36). On the other hand, a prospective evaluation of HIV-infected hemophiliacs showed that in about half of them HIV disease had not progressed from seroconversion for more than 12 years and CD4 cell counts had been maintained above $500 / \mathrm{cmm}$ (37). Recently, in all risk categories including hemophiliacs a minority of infected individuals with non progressive HIV infection have been recognized (38), but the mechanisms of slow progression of HIV disease are not well understood and are the goal of current research.

Longitudinal studies of the natural history of HIV infection in hemophiliacs provided detailed information not only on survival, progression to AIDS and clinical manifestations, but also on cofactors that affect the clinical outcome. The clinical manifestations of AIDS are roughly similar in different risk groups. However, of the HIV-related malignancies in hemophiliacs, Kaposi sarcoma is very rare, while nonHodgkin lymphoma is the most frequent and its incidence rises with the increasing duration of HIV infection with no association with CD4 cell depletion, suggesting there are other cofactors for development of this tumor (35).

Patients with hemophilia have special features that are not exclusively related to the epidemiological characteristics of the HIV epidemic in this cohort but also to the impact of coagulation factor concentrates on the immune system and to the concomitant infections with other blood-borne viruses. The results of a number of clinical studies suggested that highly purified concentrates had a beneficial effect on the decline of CD4 cell counts in HIV-positive hemophiliacs $(39,40)$. Thus, they were recommended for these patients (25). The advantage brought about by purer concentrates in terms of CD4 lymphocyte preservation is now considered to be irrelevant in hemophiliacs (26) since the recent adoption of highly active antiretroviral treatments (HAART) that has had a substantial impact on HIV disease progression, making HIV viremia undetectable, increasing CD4 cell counts and slowing progression to AIDS (41).

The effect of coinfection with HIV on the natural history of HCV infection in hemophiliacs was documented by the significantly higher prevalence of liver failure (9\%) after a latent period of 10-20 years in coinfected patients than in patients not infected with HIV (42). Higher serum HCV-RNA levels in coinfected hemophiliacs were also reported, suggesting that HIV-induced immune deficiency may enhance $\mathrm{HCV}$ replication (43). In UK hemophiliacs the cumulative risk of death from liver disease 25 years after the first concentrate infusion was $6.5 \%$ for HIV-infected patients is $1.4 \%$ for HIV-negative patients (17). 


\section{Transmission of non-lipid-enveloped viruses through factor concentrates}

Current virucidal procedures (dry heating, vapor heating, pasteurization and solvent/detergent treatment) have virtually ensured safety against $\operatorname{HIV}(44,45)$ and greatly improved that against $\operatorname{HBV}$ and $\operatorname{HCV}(46,47)$. However, the outbreaks of hepatitis A among hemophiliacs in the early $1990 \mathrm{~s}(48,49)$ have given rise among all hemophilia treaters to concern about non-enveloped viruses. Hepatitis A virus (HAV) was responsible for acute hepatitis in patients infused with solvent/detergent treated concentrates, because this virucidal procedure is not effective for inactivating viruses which do not have a lipid envelope, such as HAV. No new cases of hepatitis A have been reported in hemophiliacs since hepatitis A vaccination has been adopted for these patients and alternative or additional inactivation procedures have been used in the manufacturing process of coagulation factor concentrates.

Current virucidal methods are not effective against the non-enveloped, highly thermoresistant human parvovirus B $19(50,51)$, which has only minor clinical consequences in immunocompetent individuals, but may produce chronic infection and severe aplastic anemia in immunocompromised hosts (52). Human parvovirus B 19 is called a "sentinel" virus because its transmission through the concentrates is considered to be an indicator of potential, residual infectivity of the plasma-products.

Recently, a new non-enveloped, blood-borne virus, TTV, has been detected in patient sera in association with transaminase elevation, raising the possibility that TTV may be a new hepatotropic virus (53). TTV has also been detected in multitransfused hemophilic patients and its potential for causing hepatitis in this population is still under examination, as well as its sensitivity to virucidal procedures $(54,55)$.

\section{Other pathogenic agents potentially transmissible to hemophiliacs}

The concern that there may be other pathogenic viruses that might be transmitted by concentrates despite current virucidal methods has prompted the manufacturers to new approaches, such as ultrafiltration and nanofiltration techniques, and to combined inactivation procedures. The development in the 1990s of factor VIII and factor IX produced by recombinant DNA technology is the most important progress in hemophilia replacement therapy. Currently licensed recombinant products offer a greater margin of safety than plasma-derived concentrates with regard to viral infections $(25,26)$. Nevertheless, there are still theoretical concerns about the possibility of contamination by transmissible agents of heterologous origin in products manufactured from mammalian cell cultures, murine monoclonal antibodies or other animal proteins. As of now, there is no evidence to support this hypothesis. 
The theoretical possibility of transfusional transmission of the agent(s) causing Creutzfeld-Jacob disease (CJD) and new variant (nvCJD) with blood components and blood derivatives is still under examination, even though an association between CJD or nvCJD and hemophilia has never been demonstrated.

\section{Development of inhibitor: epidemiology and clinical management}

A subset of hemophilia patients produce inhibitor antibodies raising an immune response to coagulation factor infusions that can become strong enough to render further administrations ineffective and to be responsible for increased morbidity and mortality due to uncontrolled bleeding. Even with the availability of the most technologically advanced products, development of inhibitor remains today the main complication of hemophilia treatment, and so far we have no reason to postulate that the forthcoming gene therapy will reduce this risk. Inhibitors are distinguished into two types: lowresponding and high-responding. Low-responding inhibitor patients usually have inhibitor titers below $5 \mathrm{BU} / \mathrm{ml}$ and, when given factor concentrate, do not mount an anamnestic response. These inhibitors are not a challenge to treatment because they can be easily overcome by increasing the dosage of factor concentrate. In addition, they may be transient and disappear spontaneously over time. High-responding patients often have titers greater than $10 \mathrm{BU} / \mathrm{ml}$, which increase further to higher levels anamnestically after administration of concentrate, making attainment of adequate hemostasis highly problematic. Early retrospective studies $(56,57)$ showed that development of inhibitor was more frequent in patients with severe hemophilia A (15-25\% is $10-12 \%$ in all hemophilia $A$ patients) and most common before the age of five. More recently, prospective studies carried out with frequent and regular inhibitor assays in children with severe hemophilia A. previously untransfused and followed up during exclusive treatment with recombinant factor VIII, reported an inhibitor incidence of $25-28 \%(58,59)$, similar incidence values being reported after treatment with intermediate purity concentrates $(60,61)$. These studies demonstrated that if the inhibitor did not appear before the age of 2 , or 50 exposure days. the risk of its development was very small. Interestingly, about $30 \%$ of inhibitors subsequently resolved spontaneously. These data also demonstrated that the type of concentrate does not appear to influence development of inhibitor.

Sudden increases in development of inhibitor in multitransfused hemophiliacs, at low risk, have been reported in association with the introduction of new factor VIII concentrates (62. 63). It appears that the manufacturing method and/or the virucidal procedure adopted may lead to neo-antigenicity of the factor VIII and subsequent inhibitor formation. Thus, careful surveillance is very important when a new product is introduced in clinical practice. 
Variables which have been claimed to be relevant to inhibitor development include the type of exposure to concentrate, intrauterine exposure to maternal factor and age at first exposure, but these need to be studied further in prospective trials. Among host-related factors, HLA haplotypes are unlikely to have a major influence, and the only well established risk factor remains the mutation type. Current data show that patients with such severe gene defects as nonsense point mutations, large deletions or inversions are more prone to produce inhibitors $(64,65)$, perhaps due to the absence of circulating factor VIII and therefore the lack of immune tolerance induction. However, it has to be kept in mind that some patients develop inhibitor but others, even with the same factor VIII gene mutation, do not. The hypothesis of a genetic predisposition to develop inhibitor is supported by the observations of an increased inhibitor risk in hemophilic brother pairs and in African-Americans (66).

Inhibitors are rare in hemophilia B, occurring in approximately $1.5-3 \%$ of patients with severe disease. There is a strong association of inhibitor development with large gene deletions or loss of coding information secondary to stop codons or nonsense mutations (67).

The therapeutic approach to hemophiliacs with high-responding inhibitors is complex, particularly if there is a life-threatening bleeding or emergency surgery is required. Laboratory coagulation monitoring and prompt availability of various therapeutic products are necessary to care for these patients. Methods for by-passing the need for factor VIII replacement involve giving prothrombin complex concentrate (PCC) or activated PCC. These products appear to be effective in approximately $50-65 \%$ of bleeding episodes in patients with inhibitor (68). PCC and aPCC only rarely cause an anamnestic response, since they contain no factor VIII. Dosing is empirical and efficacy can be judged only clinically. The response to treatment is not universal or predictable. These products are associated with an increased risk of thrombotic complications (69).

More recently, another by-passing agent, human recombinant activated factor VII ( $\mathrm{FVVIIa)}$ has been used in diverse types of hemorrhages and surgical procedures with successful clinical responses in $60 \%-90 \%$ of treatment courses (70). Its mode of action, initiating hemostasis only at the site of tissue injury, minimizes systemic activation of coagulation, as demonstrated by a good safety record with regard to thromboembolic events (71). Other advantages of rFVIIa include viral safety and no anamnestic response, whereas the main disadvantages are its cost, the short half-life, the current paucity of data on optimal dose regimen and the need for laboratory monitoring.

Porcine factor VIII concentrate is an effective therapeutic option in high-responding hemophiliacs because antibodies to human factor VIII usually have low cross-reactivity towards the porcine molecule. Nevertheless, the anti-porcine factor VIII titer needs to be determined in order to evaluate this treatment option and monitoring of plasma factor 
VIII levels is required during therapy. Anamnestic responses may occur after 7-14 days of treatment; allergic reactions and thrombocytopenia are sometimes associated with porcine factor VIII infusion (72). Another alternative for treatment of high-titer inhibitors is to use high-dose human factor VIII after plasmapheresis and immunoadsorption to staphylococcal protein A to remove the $\mathrm{IgG}$ antibodies.

The choice of the treatment strategy for high-responding inhibitor patients mainly

Treatment of acute bleeding in high-responding inhibitor hemophiliacs
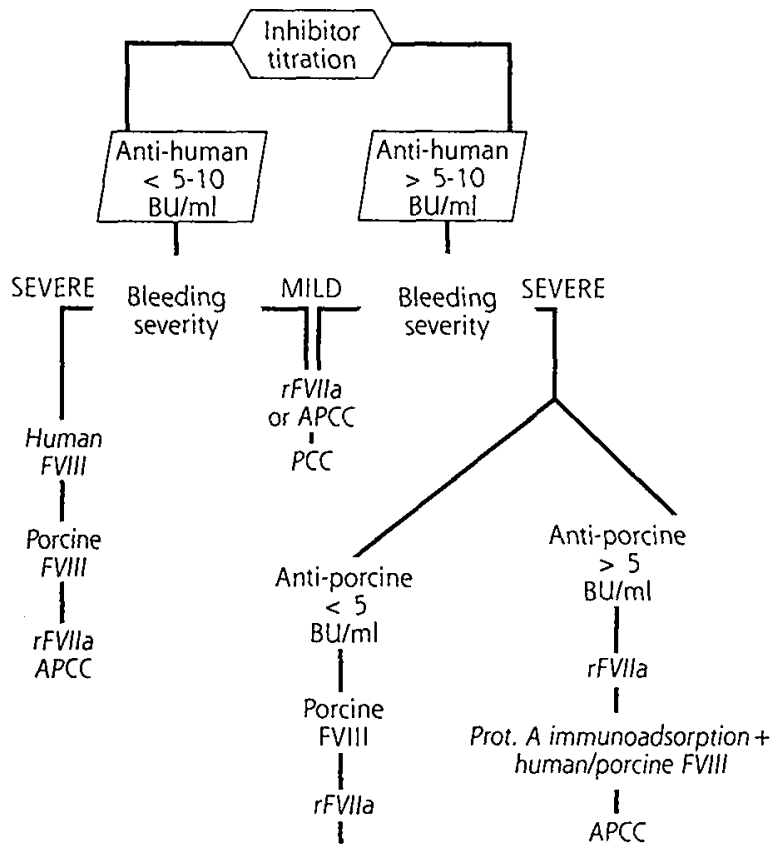

Prot. A immunoadsorption+

human/porcine FVIII

\rfloor$_{A P C C}$ depends on the severity of the hemorrhage and it is summarized in the flow chart. Suppressing inhibitor production and establishing a state of immune tolerance remain major goals. The more than 20-year experience with immune tolerance induction has included the use of both high $(\geq 200$ $\mathrm{U} / \mathrm{Kg} /$ day) and low doses (25 $\mathrm{U} / \mathrm{Kg} /$ day) of factor VIII concentrate and the overall success rates for immune tolerance therapy in hemophilia $A$ have been similar (63-83\%) while mean time for successful eradication has been variable (1.2-24 months) (73). There are still many questions about the optimal therapeutic regimen and predictors of outcome. Also, the role of adjuvant immunosuppressive agents has not been ascertained. Maintenance regimens are not uniform and the incidence of recurrence is not well established. Prospective randomized trials are now underway to compare therapeutic regimens with respect to efficacy, safety and cost effectiveness.

A recently described serious complication of replacement therapy is the occurrence of anaphylaxis simultaneously or following the development of inhibitors in hemophilia B patients (67). This unique complication poses clinical management problems, since acute bleeding cannot be treated with any factor IX-containing products, including PCC and 
aPCC. In addition, inhibitor patients with allergy to factor IX have a poor success rate with immune tolerance treatment associated with an extremely high complication rate of nephrotic syndrome. Recombinant factor Vila seems to be the most appropriate hemostatic trealment for these calses (67).

\section{Aims and structure of this thesis}

The purpose of the work described in this thesis was to gain more insight into the clinical, epidemiological and pathophysiological aspects of the main complications associated with hemophilia replacement therapy: blood-borne viral infections and development of inhibitor. The experience in the clinical management of these complications is reponted. especially with respect to the safety and the efficacy of the therapeutic interventions. Coagulation factor products have been evaluated for saffety. not only with respect to viral transmission, but also to other adverse effects that condition the feasibility of home therapy.

Treatment and complications of chronic hepatitis $\mathrm{C}$ are reported in Chapter 2. In order to evaluate the impact of interferon alpha therapy on chronic hepatitis $\mathrm{C}$ in the hemophilia population. a controlled. randomized trial was carried out in paltients not coinfected with HIV, since impaired immunity could weaken the response to treatment. Virologic characterization of the hemophiliacs in the study was performed to look for potential predictive factors for responsiveness to interferon in this population. Lymphoproliferative disorders have been described in pattients with chronic HCV infection, but little is known about their role in the natural history of liver disease. We have been the first to report the occurrence of serum cryoglobulins among hemophiliacs. assessing the prevalence of this HCV-relatted complication and finding a correlation between duration of hepatitis $\mathrm{C}$ and risk of developing cryoglobulinemia.

The hemophilia cohor regularly followed-up al our Center since HIV seroconversion hats enabled us to investigate specific aspects of the HIV infection (Chapter 3). Reliable retrospective data were available for detailed epidemiological analysis and significant factors affecting survival and HIV disease progression have been recognized. A group of hemophiliacs with non-progressive HIV infection and a comparable group with progressive infection have been identified and their virologic characteristics compared to ascertain the role of viral features in the pathogenicity of HIV disease. Other patients belonging to the same hemophilia cohort have been investigated because they have remained uninfected after multiple infusions of a large amount of HIV-contaminated concentrates. The mechanisms of natural resistance to HIV infection in this interesting group of hemophiliacs have been studied. looking for host factors which might play a protective role. especially. the early production of chemokines. the initial effectors of cellular immune response. 
Viral safety of coagulation factor concentrates needs to be established in appropriately designed, prospective clinical studies in previously untreated hemophiliacs who have been exposed only to the study concentrate. An example of this strict approach to safety assessment is the investigation on the double-inactivated factor VIII and IX products reported in Chapter 3. Serologic and virologic evaluation was carried out with special attention to non-lipid-enveloped viruses, such as parvovirus B 19 and HAV.

Our experience of the clinical management of inhibitor patients is reported in Chapter 5. The detection of high-responding inhibitor in a mild hemophilia A family and the therapeutic challenge associated with this rare condition prompted us to clinical and molecular characterization of this special hemophilia phenotype. Very few cases of inhibitor development in mild hemophiliacs, usually arising during adulthood, have been fully described in the literature. The collection of data from these reports indicates an association with high risk, single point mutations in the factor VIII gene. Data on safety and efficacy of therapeutic options for treatment of high-responding inhibitor patients are also provided in Chapter 5 , in particular with respect to the use of porcine factor VIII in different regimens for hospital and home treatment, and of recombinant factor VIIa in the home setting.

\section{References}

1. Tuddenham EGD, Cooper DN: The molecular genetics of hemostasis and its inherited disorders. Oxford University Press, 1994.

2. Rizza CR. Spooner RJD: Treatment of haemophilia and related disorders in Britain and Northern Ireland during 1976-80: report on behalf of the directors of haemophilia centres in the United Kingdom. Br Med $J 1983 ; 286$ : 929-93.3.

3. Smit C. Rosendaal FR, Varekamp I, BrockerVriends AHJT, van Dijck $H$, Suurmeijer TPBM. Briet E: Physical condition, longevity and social performance of Dutch haemophiliacs 1972-85. Br Med J 1989; 298: 235-238.

4. Fletcher ML, Trowell JM, Craske J, Pavier K. Rizza CR: Non-A, non-B hepatitis after transfusion of factor VIII in unfrequently treated patients. Br Med J 1982: 287: 1754-7. 5. Kernoff PBA. Lee CA, Karayanis P. Thomas

HC: High risk of non-A, non-B hepatitis after a first exposure to volunteer or commercial clotting factor concentrates: effects of prophylactic immune serum globulin. $\mathrm{Br} J$ Haematol 1985:

60: $469-79$.

6. Rumi MG, Colombo M. Gringeri A, Mannucci PM: High prevalence of antibody to hepatitis $C$ virus in multitransfused hemophiliacs with normal transaminase levels. Ann Intern Med 1990; 112: 379-80. 7. Makris M, Preston FE, Triger DR, Underwood JCE, Choo QL, Kuo G, Houghton $\mathrm{M}$ : Hepatitis $\mathrm{C}$ antibody and chronic liver disease in haemophilia. Lancet 1990:335: 1117-1119.

8. Watson HG. Ludlam CA, Rebus S, Zhang LQ. Peutherer JF, Simmonds P: Use of several second generation assays to determine the 
true prevalence of hepatitis $\mathrm{C}$ infection in haemophiliacs exposed to non-virus inactivated factor VIII and IX concentrates. Br.I Hae'matol 1992; 80: 514-518.

9. Lim SG, Lee CA. Charman H. Tilsed G, Griffiths PD, Kemolf PBA: Hepatitis C antibody assay in a longitudinal study of haemophiliacs. Br. Hacmatol 1991: 78: 398-402. 10. Alter $\mathrm{HJ}$ : To $\mathrm{C}$ or not to $\mathrm{C}$ : these are the questions. Blood 1995; 85: 1681-1095.

11. Mauser-Bunschoten EP. Bresters D, van Drimmelen AAJ, Roosendaal G, Cuypers HTM, Reesink HW, van der Poel CL, van den Berg HM, Lclie PN: Hepatitis $C$ infection and viremia in Dutch hemophilia patients. $J$ Med Virol 1995: 45: 241-246.

12. Mannucci PM, Capitanio A. Del Ninno E, Colombo M, Pareti F, Ruggeri Z:

Asymptomatic liver disease in haemophiliacs. J Clin Parhol 1975; 28: 620-624.

13. Hay CRM, Preston FE, Triger DR, Underwood JCE: Progressive liver disease in haemophilia: an understated problem. Lancet 1985; i: 1495-1498.

14. Schimpf $K$ : Liver disease in haemophilia. Lancet 1986; i: 323 (letter).

15. Makris M, Preston FE, Rosendaal FR, Underwood JCE, Rice KM, Triger DR: The natural history of chronic hepatitis $C$ in hemophiliacs. Blood 1996: 94: 746-752.

16. Telfer $P$, Sabin $C$, Devereux $H$, Scott $F$, Dusheiko G, Lee CA: The progression of $\mathrm{HCV}$-associated liver disease in a cohort of haemophilic patients. Br.I Haemarol 1994; 87: $555-561$

17. Darby SC. Ewart DW, Giangrande PLF, Spooner RJD, Rizza CR, Dusheiko GM, Lee CA. Ludlam CA, Preston FE, for the UK Haemophilia Centre Directors' Organisation: Mortality from liver cancer and liver disease in haemophilic men and boys given blood products contaminated with hepatitis $\mathrm{C}$. Lancet 1997: 350: 1425-1431.
18. Colombo M, Mannucci PM, Brettler DB. Girolami A, Lian ECY, Rodeghiero F, Scharrer I. Smith PS, White GC: Hepatocellular carcinoma in hemophilia. Am.J Hematol 1991; 37: 243.

19. Tradati F. Colombo M, Mannucci PM, Rumi MG, De Fazio C, Gamba G, Ciavarella N, Rocino A, Morfini M, Scaraggi A, Taioli E, and the Siudy Group of the Association of Italian Hemophilia Centres: A prospective multicenter study of hepatocellular carcinoma in italian hemophiliacs with chronic hepatitis $\mathbf{C}$. Blood 1998; 91: 1173-1177.

20. Simmonds P, Alberti A. Alter HJ, Bonino F, Bradley DW, Brecho C, Brouwer JT, Chan SW, Chayama K, et al: A proposed system for the nomenclature of hepatitis $\mathrm{C}$ viral genotypes. Hepatology 1994; 19: 1321-1324.

21. Telfer PT, Devereux H, Savage $K$ et al. Chronic hepatitis $C$ virus infection in haemophilic patients: clinical significance of viral genotype. Thromb Haemost 1995; 74 : 1259-1264.

22. Misiani R, Bellavita L, Fenili D. Vicari O, Marchesi D, Sironi PL, Zilio P, Vernocchi A, Massazza $M$, et al: Interferon alfa-2a therapy in cryoglobulinemia associated with hepatitis C virus. New' Engl I Med 1994: 330: 75/-756. 23. Pawlotsky JM, Ben Yahia M, Andre C, Voisin MC, Intrator L, Roudot-Thoraval F, Desforges L, Duvoux P, Zafrani ES, et al: Immunologic disorders in $\mathrm{C}$ virus chronic active hepatitis: a prospective case-control study. Hepatology 1994: 19:841-848.

24. Zuckerman E, Zuckerman T, Levine AM, Douer D, Gutekunst K, Mizokami M, Qian DG, Vielanker $M$, Nathwani BN, Fong TL:

Hepatitis $C$ virus infection in patients with $B$ cell lymphoma. Ann Intern Med 1997: 127: 423-428.

25. United Kingdom Haemophilia Centre Directors' Organisation Executive Committec: Guidelines on therapeutic products to treat 
haemophilia and other hereditary coagulation disorders. //ac'meph/rilia 1997: i: 0.3-77.

26. Santagostino f: Mannucei PM: Guidelines on replacement therapy for haemophilia and inherited coagulation disorders in Italy.

Hacmeph hilia 200(0): 6): 1-10).

27. Colombo M. Rumi MGi. CiringeriA.

Manucci PM: Etiology and outcome of chronic viral hepatitis in multitransfused haemophilic patients. in Pathophysiolegy of the

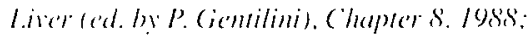

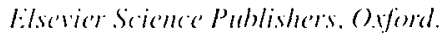

28. Hanley JP. Dolan (i. Daty S. et al: Interaction of hepatitis $B$ and hepatitis $C$ infection in haemophilia. $B r . /$ /lacmatol /993: $8.5: 0 / 1-0 / 2$

29. Jarvis I.M. Davidson F. Hanley JP. Yap PL. 1.udlam CA. Simmonds P: Infection with hepatitis $\mathrm{G}$ among recipients of plasma pro-

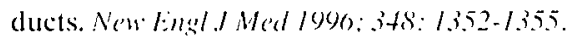
30. De Filippi F. Colombo M. Rumi MG. Tradau F, Prati D. Zanella A, Mannucei PM: High rates of hepatitis $G$ virus infection in multitransfused patients with hemophilia. Bhosed 1997: 90: 40.3t-46.37.

31. Pneumocystis carinii pneumonia among persons with hemophilia A. MMWR Merh Morfal Wh/y R(p) /982: : 1/:36.5-3607.

32. (iallo RC. Salahuddlin S\%. Popovic M. Shearer (iM. Kaplan M. Haynes BF. Palker TJ. Recilield R. Oleske J. el al: Frequent detection and isolation of cytopathic retroviruses (HTLV-IIl) from patients with AIDS and at risk for AIDS. Srience 1984: 224: $50(1)-503$. 33. Ciocdert JJ. Samgadharan MG. Eyster ME. Weiss SHI. Bodner AJ. (iallo RC. Blattuer WA: Antibodies reactive with human $T$ cell leukemia viruses in the serum of hemophiliacs receiving factor VIII concentrate. Blood $19.55: 0.5: 492.495$.

34. Evatt BL. Comperts ED, MeDougal JS. R:mnsey RB: Coincidental appearance of L.AV/HTI.V-III antibodies in hemophiliacs and the onset of the AIDS epidemic. Now lingl I Med /985: 3/2: 483-486.

35. Lee CA: Transfusion transmitted diseases. In Bailliere's Clinical hae'matology: Imernational Practice and research. Hacmophilia, vol. 9 (ed by Bailliese Tïndall) Chapler 11. 1996; London.

36. Darby SC. Ewart DW, Giangrande PLF. Dolin PJ. Spooner RJD. Rizaa CR. on bebalf of the UK Hatemophilial Centre Directors" Organisation: Mortality before and after HIV infection in the complete UK population of haemophiliacs. Nature 1995: 377: 79-82. 37. Phillips AN. Elford J. Sabin C. Bofill M. Janossi G. Lee CA: Immunodeficiency and the risk of death in HIV infection. Iama 1992: 268: 2002-2006.

38. Easterbrook PJ: Non-progression in HIV infection. A/DS $199+: S: 1 / 79$.

39. Seremetis SV. Aledort LM. Bergman GE. et al: Three-year randomised study of highpurity or intermediate-purity factor VIII concentrates in symptom-free HIV seropositive haemophiliacs: effects on immune status. Lance' 1993: 342: 700)-3.

40. De Biasi R. Rocino A. Miraglia E. Mastrullo L. Quirino AA: The impact of a very high purity factor VIII concentrate on the immune system of human immunodeficiency virus-infected hemophiliacs: a randomized, prospective, two-year comparison with an intermediate purity concentrate. Bloed 1991: 78: 1919-22.

41. Merry C. McMahon C. Ryan M. O Shea E. Mulcahy F. Smith OP: Successful use of protease inhibitors in HIV-infected haemophilia patients. Br.J Ha'muatol 199S: 101: $175-9$. 42. Eyster ME, Diamondstone LS. Lien JM. Elumam C. Quan S. Goedent JJ, for the Multicenter Hemophilia Cohort Study: Natural history of hepatitis $\mathrm{C}$ infection in multitransfused hemophiliacs: effect of coinfection with human immunodeficiency virus. $I A I D S$ 
1993:0:002-610.

43. Eyster ME. Fried MW. Di Bisceglie AM. Goedert JJ. for the Multicenter Hemophilia Cohort Study: Increasing hepatitis $C$ virus RNA levels in hemophiliacs: relationship to human immunodeficiency virus infection and liver discase. B/oed / 1994: $54: 1020-1023$.

44. Schimpl K. Brackmann HH, Kreuz W. clal: Absence of anti-human immunodeficiency virus types 1 and 2 seroconversion after the treatment of hemophilia $A$ or von

Willebrand's discase with pasteurized factor VIII concentrate. $N$ lingl I $M_{c^{\prime}} / / 989: 321$ : $1 / 48-52$.

45. Di Paolantonio T. Mariani G. Ghirardini A. et al: Low risk of transmission of the human immunodeficiency virus by a solvent-detergent-treated commercial factor VIII concentrate. I Med lïol 1992: 36: 7/-4.

46. Mannucci PM. Schimpt K. Brenler DB. et al. and the International Sudy Group: Low risk for hepatitis $C$ in hemophiliaes given a highpurity, pasteurized factor VIII concentrate. Amlintern Med 1990: 11.3: 27-.32.

47. Mannucei PM. Schimpf K. Abe T, et al, and the International Study Group: Low risk of viral infection after administration of vapourheated factor VIII concentrate. Trams/usion $1992: 32: 134-8$.

48. Peerlinck K. Vermylen J: Acute hepatitis A in patients with haemophilia A. Lanc' (199.?: ifl: 179 .

49. Mannucci PM. Gdovin S. Gringeri A. el al: Transmission of hepatitis $A$ to patients with hemophilia by factor VIII concentrates treated with organic solvent and detergent to inactivate viruses. Ann /

50. Azzi A. Ciappi S. Zakvrewska K. Mortini M. Mariani G. Mannucei PM: Human parvovirus $B 19$ infection in hemophiliacs first infused with two high-purity, virally attenuated. factor VIII concentrates. Am I Hemalol 1992 : $39: 228-30$.
51. Santagostino E. Mannucci PM. Gringeri $A$. Arzi A. Mortini M: Eliminating parvovirus B19 from blood products. Lance / 1994 : it. 798 .

52. Frickhoten N. Abkowit\% II. Salford $\mathrm{Met}$ a): Persistent $B 19$ parvovirus infection in patients infected with human immunodeficiency virus type 1 (HIV-1): a treatable cause of ancmia in AIDS. $1 / 1 \mathrm{~m} / \mathrm{me} / \mathrm{m}$. Med 1990 : 11.3: 920.9.3.

53. Nishizawa T. Okamou H. Konishi K. Yoshizawa H. Miyakawa Y. Mayumi M: A novel IDNA virus (TTV) associated with elevated transaminase levels in posttransfusion hepatitis of unknown etiology. Biw $/$ Biophys Res Comm 1997: 241: 92.

54. Simmonds P. Davidson F. Lycen C. Prescont LE. MacDonald DM. Ellender J. Yap PL.

Ludlam CA. Haydon CiH el al: Detection of a novel DNA virus (TTV) in blood donors and blood products. Lemeel 1998: $352: 191$

55. Chen BP. Rumi MG. Colombo M. Lin YH. Ramaswamy L. Luna J. Liu JK. Prati D). Manmucei PM: TT virus is present in a high frequency in italian hemophilic patients transfuse with plasma derived clotting factor concentrates. Blood 1999: 94: 43.3.4.36.

56. Lusher JM: Factor VIIl inhibitors : etiology, charcaterization, natural history and management. Amn NY Acod Soic 1987: 509 S9. 102 .

57. McMillan CW. Shapiro SS. Whitchurst I). et al: The natural history of factor VIII inhibitorsin patients with hemophilia $A$ : a national

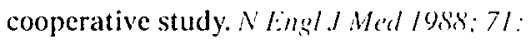
ift-ifs.

58. Lusher JM. Arkin S. Abildgalud CF. el al: Recombinant factor VIII for the treatment of previously untreated patients with hemophilia A - safety, efficacy, and development of inhibitors. $N$ Engl / Med 1993: 328: 453-9. 59. Bray GL. Comperts ED. Courter S. el al: A multicenter study of recombinant factor VII] 
(recombinate): safety, efficacy, and inhibitor risk in previously untreated patients with hemophilia A. Blood 1994; $83: 2428-35$. 60. Addiego JE, Jr., Gomperts E, Liu SL, et al: Treatment of hemophilia A with a highly purified factor VIII concentrate prepared by anti-FVIII immunoaffinity chromatography. Thromb Hacmost 1992; 67: 19-27.

61. Ehrenforth S, Kreuz W, Scharrer 1, et al: Incidence of development of factor VIII and factor IX inhibitors in haemophiliacs. Lancet 1992: 339: 594-8.

62. Peerlinck K. Arnout J, Gillies JG, SaintRemy JM. Vermylen J: A higher than expected incidence of factor VIII inhibitors in multitransfused haemophilia A patients treated with an intermediate purity pasteurized factor VIII concentrate. Thromb Haemost 1993; 69: $115-8$.

63. Peerlinck K, Anout J, Di Giambattista M, et al: Factor VIII inhibitors in previously treated haemophilia A patients with a double virus-inactivated plasma derived factor VIII concentrate. T/homb Haemost 1997; 77: 80-6.

64. Tuddenham EGD, Schwaab R, Sechafer J, Millar DS, Gitschier J, Higuchi M,

Bidichandani S. Conor JM, et al: Haemophilia A: database of nucleotide substitutions, deletions, insertions and rearrangements of the factor VIII gene, second edition. Nucl Acids Res 1994: 22:351/-3533.

65. Antonarakis SE, Rossiter JP. Young M. Horst J, de Moerloose P. Sommer SS, Ketterling RP, Kazazian $\mathrm{HH}$, et al: Factor VIII gene inversions in severe hemophilia $\mathrm{A}$ : results of an international consortium study. Blood 1995; 86: 2206-22/2.

66. Addiego J, Kasper C. Abildgaard C et al: Increased frequency of inhibitors in AfricanAmerican hemophilia A patients. Blood 1994: 84: $239 a$.

67. Warrier I: Management of haemophilia B patients with inhibitors and anaphylaxis.

Haemophilia 1998: 4: 574-576.

68. Lusher JM, Shapiro SS, Palascak JE, Rao AV, Levine PH, Blatt PM, for the Hemophilia Study Group: Efficacy of prothrombin-complex concentrates in hemophiliacs with antibodies to factor VIII : a multicenter therapeutic trial. $N$ Engl J Med 1980: 303: 42 I-425. 69. Schimpf K, Zeltsch C. Zeltsch P:

Myocardial infarction complicating activated prothrombin complex concentrate substitution in a patient with haemophilia A. Lancet 1982: ii: 1043 .

70. Lusher JM, Ingerslev J, Roberts H, Hedner $\mathrm{U}$ : Clinical experience with recombinant factor VIla. Blood Coagul Fibrinol 1998; 9: 119. 128.

71. Hedner U, Glazer S: Management of hemophilia patients with inhibitors.

HematollOncol Clin North Am 1992; 6: 1035 1046.

72. Gringeri A, Santagostino E, Tradati F, Giangrande PLF, Mannucci PM: Adverse effects of treatment with porcine FVIII. Thromb Haemost 1991: 65: 245-247.

73. Di Michele DM: Immune tolerance: a synopsis of the international experience. Haemophilia 1998: 4: 568-573. 


\section{Chapter 2}

\section{Treatment of chronic hepatitis $C$ and its complications}

- A multicenter controlled, randomized, open trial of interferon $\alpha 2 b$ treatment of anti-human immunodeficiency virus-negative hemophilic patients with chronic hepatitis $\mathrm{C}$. Blood 89: 3529-3533,1997

- High prevalence of serum cryoglobulins in multitransfused hemophilic patients with chronic hepatitis $\mathrm{C}$.

Blood 92: 516-519,1998 


\section{A multicenter controlled, randomized, open trial of interferon $\alpha 2 \mathrm{~b}$ treatment of anti-human immunodeficiency virus-negative hemophilic patients with chronic hepatitis $C$}

M. G. Rumi'. E. Santagostino', M. Morfini', A. Gringeri', G. Tagariello', A. Chistolini'. P. Pontisso". A. Tagger". M. Colombo'. P.M. Mannucci', and the Hepatitis Study Group of the Association of Italian Hemophilia Centers

I Insitute of Internal Medicine and Angelo Bianchi Bonomi Hemophilia and Thrombesis C'mter, University of Milan, IRCCS Maggione IIospital, Milan. Italy: 2Department of Hematolog! and I lemophilia C'nter, Careggi Hospital, Florence. Italy:

"I. Tosatti Hemophitia Center. Castelfrancen Veneto Hospial, Treriso, Italy:

+ Department of Biopathology: La Sapiensa Universits: Rome. Inaly:

s Clinica Medica 2. University of Padora. Padora, Laly;

"Institute of Virologn: University of Milan. Milan, Italy: 


\begin{abstract}
There is limited information about the long-term efficacy of prolonged therapy (more than 6 months) with interferon $\alpha$ in hemophilic patients with chronic hepatitis $\mathrm{C}$ who are not coinfected with the human immunodefieiency virus (HIV-1). One hundred and seven hemophiliacs were randomly assigned to 3 million $U$ of interferon $\alpha 2 b$ three times weekly for 12 months or no therapy. The patients were followed up for at least 12 months posttreatment. Response was assessed by both serial alanine aminotransferase (ALT) levels and hepatitis C virus (HCV)-RNA measured by reverse transcribed polymerase chain reaction (RT-PCR) method. Before treatment, serum levels of HCV-RNA were measured quantitatively by second-generation branched-DNA assaly and the HCV genotype was determined by RT-PCR. Serum HGV-RNA. a marker of infection with the hepatitis $G$ virus, was also measured by RT-PCR. Nomalization of ALT was sustained and serum HCV-RNA was cleared in 6 of 45 treated patients, compared with none of the 50 untreated controls $(13 \%, 10 \%, \mathrm{P}<.01)$. Low pretreatment viremia was the only feature that was associated with an increased likelihood of sustained response $(\mathrm{P}<. .01)$. This study shows that multitransfused hemophiliacs with chronic hepatitis $C$ not coinfected with HIV-I respond at low rates to prolonged interferon therapy.
\end{abstract}

\title{
Introduction
}

Most hemophilic patients. who in the past have been treated with large-pool plasmaderived clotting factor concentrates, are persistently infected with the hepatitis $\mathrm{C}$ virus (HCV), a condition that entails a high risk of morbidity and mortality. 1.2 In $15 \%$ to $25 \%$ of nonhemophilic patients with chronic hepatitis $C$. interferon $\alpha$ therapy has been shown to suppress HCV replication and nomalize serum alanine aminotransferase (ALT) long-term. ${ }^{35}$ Whether this also happens in hemophilic patients is unclear. The few. small pilot studies in hemophilia performed thus far have given disappointingly low rates $(0 \%-8 \%)$ of sustained virologic responses to interferon. ${ }^{-4}$ Treatment failures were thought to result from specific epidemiologic and virologic characteristics of hemophilic patients, as well as from coinfection with the human immunodeficiency virus (HIV-1). HIV-I is present in $30 \%$ to $50 \%$ of the patients with hepatitis $\mathrm{C}$. and this might weaken the anti-HCV activity of interferon $\alpha$ by impairing host immunity. thus facilitating multiplication of HCV and hastening the patients' deaths.7.9-11 A demonstration that interferon can stop hepatitis $\mathrm{C}$ in the hemophilic patients who are not coinfected with HIV-I woukd have important clinical implications. since in many hemophilia centers patients with hepatitis $\mathrm{C}$ uninfected with HIV-I outnumber those who are concurrently infected with HCV and HIV-1.12-14 We have carried out a multicenter, randomized. controlled trial to assess the efficacy and tolerability of interferon $\alpha 2 b$ in antiHIV seronegative hemophilic patients with chronic hepatitis $C$. We chose to treat 
patients for 12 months instead of the standard 6-month period, because several studies in nonhemophilic patients have suggested that prolonging interferon therapy should increase the rates of responses to treatment.5.15 A subsidiary aim of this study was to assess whether HCV genotype and/or pretreatment serum HCV-RNA might predict response to interferon.

\section{Materials and Methods}

Study Design. This multicenter trial was designed as a randomized, controlled, open study. Nine Italian Centers participated: "Angelo Bianchi Bonomi" Hemophilia and Thrombosis Center, University of Milan; Department of Hematology and Hemophilia Center, Careggi Hospital, Florence; Department of Biopathology, La Sapienza University, Rome; Department of Hematology, Nuovo Pellegrini Hospital, Naples; Hemophilia and Thrombosis Center, Policlinico Hospital, Bari; Department of Internal Medicine, University of Pavia; Hemophilia Center, Hematology Division, Pugliese Hospital, Catanzaro; "E. Tosatti" Hemophilia Center, Castelfranco Veneto Hospital; Pediatric Division, G. Gaslini Hospital, Genoa. The study conformed to international standards of good clinical practice and was approved by the Institutional Review Board of each hospital. All patients gave their written informed consent according to the Declaration of Helsinki.

Between December 1992 and February 1994, 107 patients were enrolled. Random assignment was conducted by a computer-generated list kept by the principal investigator (MC) blind to the clinical data. Patients were randomly assigned to 3 million units of recombinant interferon $\alpha 2 b$ (Intron A, Schering-Plough, Milan, Italy) by subcutaneous injections thrice weekly for 6 months or to no therapy. Patients showing a biochemical response to treatment continued to take the same dose of interferon for 6 additional months (total duration of treatment $=12$ months). Patients who did not respond to therapy at month 6 or who had a permanent breakthrough during therapy discontinued interferon but continued with follow-up until the end of the study. All patients, treated and untreated, were followed up for at least 12 months after cessation of treatment (total duration of follow-up: 24 months).

Patient Selection. Patients with congenital bleeding disorders (Hemophilia A and $B$, von Willebrand disease) were included if they were older than 14 years and had serum anti-HCV, HCV-RNA detected by RT-PCR method and ALT values greater than two times the upper limit of normal range, on three consecutive occasions 6 months apart before enrollment. Patients were not included if they had serum HBsAg or HBV-DNA in the presence of isolated anti-HBc. Additional criteria for exclusion were serum anti-HIV, serum organ and nonorgan specific autoantibodies, white blood cell counts less than $3,000 / \mathrm{mm}^{3}$, platelet counts less than $100,000 / \mathrm{mm}^{3}$, abnormal 
tests of thyroid function, decompensated cirrhosis, liver cell cancer, an ethanol intake greater than $80 \mathrm{~g} / \mathrm{die}$, or previous treatments with either interferon or steroids.

Patient Monitoring. The following parameters were assessed before beginning treatment: anti-HCV, HCV-RNA, HBsAg and HBV-DNA, liver function tests, urea, creatinine, complete blood counts, and abdominal ultrasound. In the same pretreatment sera, quantitative serum levels of HCV-RNA, virus genotypes, and HGV-RNA were assessed retrospectively. RT-PCR for HCV-RNA and abdominal ultrasound were repeated at the end of treatment (month 12) and follow-up (month 24). Liver function and routine chemistry tests were performed at monthly intervals during the 12 months of therapy, then at 3-month intervals until the end of follow-up.

Definition of Response. A primary response to treatment was complete normalization of serum ALT and aspartate aminotransferase (AST) values during the first 6 months of interferon administration. Cases with partial reduction in transaminases were considered nonresponders. In the primary responders, a breakthrough was any increase in serum transaminases occurring during interferon administration. Nonresponse was persistence of serum transaminase values above the normal limits during the first 6 months of therapy. A complete response was a negative RT-PCR result for serum HCV-RNA and normal transaminase values at the end of the 12month treatment period. Patients showing a complete response at the end of the treatment period and at the end of the follow-up (month 24) were considered to have sustained complete response. A relapse was defined as an increase in serum transaminase values above the upper limit of normal occurring at any time after treatment had been completed.

Measurements. ALT and AST were measured by automated optimized colorimetry at $37^{\circ} \mathrm{C}$. Commercially available enzyme immunoassays were used to determine serum HBsAg, anti-HBs, anti-HBc, anti-HIV-l (Abbott Laboratories, Chicago, IL), anti-HCV (EIA-2 Ortho Diagnostic System, Raritan, NJ), and levels of thyrotropin (Boehringer Mannheim, Mannheim, Germany). Factor VIII inhibitor was assayed by the Bethesda method and expressed as BU/mL. Antibodies to nuclear, smooth muscle, mitochondrial, and liver-kidney microsomal antigens were detected on rat liver and kidney cryostat sections by immunofluorescence. HBV-DNA was detected by dot-blot hybridization, with a previously described method. "HCV-RNA was detected by nested RT-PCR, using specific primers from the 5' noncoding region as previously described. ${ }^{17}$ The minimum detectable level of HCV-RNA was calculated to be approximately 50 virus particles/mL. HCV-RNA was quantitated in the pretreat ment serum specimens with a branched DNA signal amplification assay (bDNA, Quantiplex, HCV-RNA 2.0 Assay; Chiron Co, Emeryville, CA). ${ }^{1 \mathrm{~T}}$ The sensitivity threshold for bDNA was calculated to be 0.2 million equivalents per $\mathrm{mL}(\mathrm{MEq} / \mathrm{mL})$. 
HCV genotypes were identified by nested PCR amplification with type-specific primers of the core and NS5b regions." Newly designed type-specific primers in both core and NS5b regions were used in the second round of PCR. HGV-RNA was detected in serum by RT-PCR amplification with nested primers from the highly conserved 5 untranslated region.2" First-strand cDNA synthesis was primed with G362 antisense primer (5'-GTC AAG AGA GAC ATT GAA GGG-3'.nt 362 to 342 ). The resulting cDNA was amplified by PCR with primers G97 (5'-GAC CGG CCA AAA GGT GGT GG-3․ nt 97 to 116) and G362. The

Table 1. Virological characteristics and ALT pattern of the hemophilic patients attending the nine participanting centers

$\begin{array}{lrl}\text { Patients } & n \text { (\% of total) } \\ \text { All } & 2,411 & (100) \\ \mathrm{HCV}+ & 1.977 & (82) \\ \mathrm{HCV}+\text { /HIV- } & 1.398 & (58) \\ \mathrm{HCV}+/ H I V-/ A L T * & 435 & (18) \\ \text { Above, with HCV-RNA } & 404 \quad(17) \\ \text { * ALT values greater than two times the upper limit of normal }\end{array}$
product from the first amplification was subjected to a second round of nested PCR amplification using primers $\mathrm{G} 120)^{\circ}\left(5^{\circ} \mathrm{GGT}\right.$ GAT GAC AGG GTT GGT AG-3*, nt 120 to 139$)$ and $\mathrm{G} 340\left(5^{\circ}-\mathrm{GAC}\right.$ GTG GAC CGT ACG TGG G-3․ nt 340 to 322). Analysis wats performed in duplicate for each specimen. Specimens that gave positive results were confirmed by RT-PCR analysis with two sets of nested primers derived from the putative NS3 helicase region.

Cirrhosis was established on the basis of clinical signs of portal hypertension (platelets fewer than $150.000 \mathrm{~mm}$, albumin less than $3.5 \mathrm{~g} / \mathrm{L}$. serum cholinesterase activity less than $4.500 \mathrm{U} / \mathrm{L}$ ). endoscopic signs (presence of esophageal varices, portal hypertensive gastropathy), and/or by abdominal ultrasound (irregular margins of the liver. dilated portal vein axis, splenomegaly).

Statistical Analysis. Continuous vartiables were expressed as mean values and standard deviations. Categorical variables were expressed as frequency and percent values.

Univariate analysis was applied to each variable to assess any association with response to treatment. Chi-square analysis or Fisher's exact tests were used for categorical variables.

Wilcoxon rank-sum test was used for continuous variables. The median values were compared by the median test for two samples.

\section{Results}

Baseline Characteristics of the Patients. Two thousand four hundred eleven patients attended the nine participating centers. Fifty-eight percent (1.398) were serum anti-HCV positive but anti-HIV negative. Of these, 435 (18\% of total) hatd ALT values greater than two times the upper limit of normal range on three consecu- 
tive checkups (Table 1). One hundred seven patients were eligible for the study: 101 accepted to be enrolled. The patients" characteristics at entry are summarized in Table 2. Fifty patients were allocated to trealment. and 51 to the untreated group. At the start of therapy, the two groups were comparable in terms of age, severity of clotting defect. serum levels of ALT, prevalence of cirrhosis, genotype distribution, and prevalence of HGV-RNA. By converse, treated patients were found to have higher pretreatment viremiat than control patients ( 1.5 is 1.1 $\mathrm{MEq} / \mathrm{mL} . \mathrm{P}<0.03)$. Of

the 101 pa-tients included, live in the treatment group and one untreated control dropped out. Reasons for dropping were onset of severe flu-like symptoms on day 15 ( 1 calse); refusal to continue therapy ( 3 cases) at months 1,3 , and 4 , and interrupted follow-up at months 6 and 15. Only one of these patients showed a primary response. The characteristics of the 6 patients who dropped out from the study were similar to those of the 95 patients (45 treated. 50 controls) who completed the study.

Response to Treatment. Twenty (44\%) treated patients hat a primary response to interteron: however, five $(11 \%)$ of them had breakthroughs 4 to 10 months after the onset of treatment. Thus. only $15(33 \%)$ patients had a biochemical persistent response to interferon. Considering the five patients with breakthrough, $30(67 \%)$ patients were nonresponders. The corresponding figures for the 50 untreated patients were $2(4 \%)$ primaly responses, o breakthroughs, and $48(96 \%)$ nonresponses. At the end of the treatment. $12(27 \%)$ treated patients and none of the untreated controls
Table 2. Characteristics of the 101 hemophilic patients included in the study

\begin{tabular}{|c|c|c|c|c|c|}
\hline \multirow[b]{2}{*}{ Age $(y r)^{*}$} & \multicolumn{2}{|c|}{ Treated $(n=50)$} & \multicolumn{2}{|c|}{ Untreated $(n=51)$} & \multirow{2}{*}{$\begin{array}{l}P \text { Value } \\
\text { NS }\end{array}$} \\
\hline & 33 & $(14-54)$ & 34 & $(14-61)$ & \\
\hline \multicolumn{6}{|l|}{ Hemophilia A } \\
\hline Mild & 7 & $(14 \%)$ & 10 & $(20 \%)$ & \\
\hline Moderate & 7 & $(14 \%)$ & 6 & $(12 \%)$ & \\
\hline Severe & 26 & $(52 \%)$ & 26 & $(51 \%)$ & NS \\
\hline $\begin{array}{l}\text { Hemophilia B } \\
\text { von Willebrand }\end{array}$ & 7 & $(14 \%)$ & 6 & $(12 \%)$ & \\
\hline disease & 3 & $(6 \%)$ & 3 & $(6 \%)$ & \\
\hline $\operatorname{ALT}(I \mathrm{U} / \mathrm{L})^{\star}$ & 125 & $(27-455)$ & 135 & $(34-312)$ & NS \\
\hline Cirrhosis & 3 & $(6 \%)$ & 2 & $(4 \%)$ & NS \\
\hline \multicolumn{6}{|l|}{ HCV-RNA } \\
\hline $\mathrm{MEq} / \mathrm{mL}^{\circ}$ & 1.5 & $(<0.2-11.0)$ & 1.1 & $(<0.2-13.9)$ & $<.03$ \\
\hline \multicolumn{6}{|l|}{ No. with } \\
\hline genotype la & 26 & $(52 \%)$ & 19 & $(37 \%)$ & \\
\hline $1 b$ & 10 & $(20 \%)$ & 9 & $(18 \%)$ & \\
\hline 2 & 3 & $(6 \%)$ & 9 & $(18 \%)$ & \\
\hline $3 a$ & 11 & $(22 \%)$ & 14 & $(27 \%)$ & \\
\hline HGV-RNA pos & 5 & $(10 \%)$ & 3 & $(6 \%)$ & NS \\
\hline
\end{tabular}


Table 3. Response to interferon therapy in 95 patients

$\begin{array}{lrrl}\text { Responses } & \text { Treated } n=45 & \text { Untreated } n=50 & \text { PValue } \\ \begin{array}{l}\text { During treatment } \\ \text { Primary responders }\end{array} & 20(44 \%) & 2(4 \%) & <.002 \\ \begin{array}{l}\text { Breakthroughs } \\ \text { Nonresponders }\end{array} & 5(11 \%) & 0 & <.05 \\ \begin{array}{l}\text { End of treatment } \\ \text { Complete responders }\end{array} & 12(56 \%) & 48(96 \%) & <.001 \\ \begin{array}{l}\text { End of follow-up } \\ \text { Complete responders }\end{array} & 6(13 \%) & 0 & <.001 \\ \end{array}$

Complete response means normal transaminase values and negative RT-PCR for HCV-RNA

Table 4. Characteristics of the sustained complete responders versus nonresponders and transient responders

\begin{tabular}{|c|c|c|c|c|c|}
\hline \multirow{2}{*}{$\begin{array}{l}\text { Features Value } \\
\text { Age }(y r)^{\star}\end{array}$} & \multicolumn{2}{|c|}{$\begin{array}{l}\text { Sustained Complete } \\
\text { Responders }(n=6)\end{array}$} & \multicolumn{2}{|c|}{$\begin{array}{l}\text { Nonresponders } \\
\text { and Transient } \\
\text { Responders }(n=39)\end{array}$} & $P$ \\
\hline & 40 & $(29-52)$ & 33 & $(14-54)$ & NS \\
\hline ALT (IU/L)* & 110 & $(27 \cdot 234)$ & 132 & $(38-455)$ & NS \\
\hline Cirrhosis & 0 & & 3 & $(8 \%)$ & NS \\
\hline b-DNA $(\mathrm{MEq} / \mathrm{mL})^{\circ}$ & & $(<0.2-1.4)$ & 2.0 & $(0.3-11)$ & $<.01$ \\
\hline \multicolumn{6}{|l|}{ Genotype } \\
\hline $1 a$ & 4 & $(67 \%)$ & 20 & $(51 \%)$ & \\
\hline $1 b$ & 1 & $(17 \%)$ & 8 & $(21 \%)$ & NS \\
\hline 2 & 0 & & 2 & $(5 \%)$ & \\
\hline $3 a$ & 1 & $(17 \%)$ & 9 & $(23 \%)$ & \\
\hline HGV-RNA pos & 0 & & 5 & $(13 \%)$ & NS \\
\hline
\end{tabular}

had a complete biochemical and virologic response. At the end of the follow-up, six (13\%) treated patients and none of the controls had sustained complete re-sponses. All the differences in the response rates between treated and untreated patients were statistically significant (Table 3).

Adverse Effects. During the study, interferonrelated adverse events were sought for by both open inquiry and by inquiry about specific effects. One $(2 \%)$ patient dropped out of the study following grade 3 fever at month 1 and four (8\%) required dose reduction for thrombocytopenia, fatigue, and leukopenia, between month 3 and month 6. An influenzalike syndrome was reported by $82 \%$ of the patients accompanied by headache in one, myalgias in four, and arthralgias in one. One patient had mild psychological depression and one developed alopecia.

Correlation Studies. The characteristics of the six patients who showed sustained complete responses to treatment and those of the 39 who transiently responded or did not respond at all are summarized in Table 4 . Univariate analysis revealed a correlation between pretreatment viremia and response to therapy $(0.5 \mathrm{MEq} / \mathrm{mL}$ v $2.0 \mathrm{MEq} / \mathrm{mL}, \mathrm{P}<.01)$. 


\section{Discussion}

Anti-HIV negative hemophilic patients with chronic hepatitis $\mathrm{C}$ are at risk of significant liver-related morbidity and mortality. Hepatomegaly or clinical signs of advanced liver disease were detected in at least one third of all anti-HIV negative hemophiliacs with HCV who were followed-up for longer than 10 years.9.21 In a cohort study of 138 patients, 22 years after $\mathrm{HCV}$ infection, $19 \%$ developed cirrhosis and $9 \%$ developed liver failure. 22 Hepatitis $\mathrm{C}$ progressed to endstage liver disease in both the $36 \mathrm{HIV}$-infected patients and the 102 HIV-negative ones.22 Liver disease was a major cause of morbidity and mortality in HIV-uninfected hemophilic patients.

This is the first randomized controlled study of interferon therapy that has enrolled exclusively hemophilic patients with chronic hepatitis $\mathrm{C}$ not coinfected with HIV-1. We chose these patients to avoid potential confounding with HIV-related treatment failures. Among other factors, HIV-1 is thought to be implicated in the poor treatment outcomes observed in the previous studies in hemophiliacs. $6^{-8}$ Moreover, in this study for the first time, interferon treatment was extended to 12 months instead of the standard period of 6 months, since previous studies in nonhemophilic patients showed that increasing the duration of treatment might also increase the chances of a sustained response. $5,1,5$

In our study, interferon treatment of anti-HIV seronegative hemophiliacs with chronic hepatitis $\mathrm{C}$ led to sustained clearance of serum HCV-RNA and normalization of ALT values in six (13\%) patients, compared with none in the control group, a difference that was statistically significant $(\mathrm{P}<.01)$. However, these figures are lower than those reported in studies of nonhemophilic patients treated with a similar schedule of interferon. A recent study of 61 Italian nonhemophilic patients treated for 1 year with 3 million $\mathrm{U}$ of interferon $\alpha$ showed $25 \%$ rates of sustained complete responses. ${ }^{5}$

The low rates of sustained responses to interferon that we observed suggest that factors other than HIV-1 may interfere with treatment outcome in hemophilia. In our patients, poor responsiveness to interferon could be due to excess virus load as is suggested by the pretreatment levels of viremia that we detected with the bDNA assay. In agreement with a previous study, we found that hemophilic patients had fairly high levels of HCV-RNA (1.3 MEq/mL), which may result from several factors, including impaired patient immunocompetence due to repeated exposures to allogenic serum proteins ${ }^{23}$ and accumulation of multiple virus strains (quasispecies), resulting from repeat infusions with infected clotting factor concentrates. ${ }^{24.25}$ Unfortunately, the small number (six) of patients showing sustained responses to interferon prevents us from assessing with multivariate analysis the potential predictive power of viremia. However, in at least three studies in nonhemophilic patients with chronic hepatitis $C$, 
multivariate analysis showed a clear-cut correlation between high pretreatment viremia and increased risk of nonresponse to interferon. $26.2 \mathrm{x}$

Poor responsiveness to interferon in hemophiliacs could be due also to the long duration of $\mathrm{HCV}$ infection, another weli-recognized predictor of poor response in nonhemophilic patients. ${ }^{20}$ Our patients were 33 years old. on the average, suggesting a corresponding long duration of their $\mathrm{HCV}$ infections, because it is very likely that $\mathrm{HCV}$ was first transmitted at the time of the first infusion with unsterilized factor concentrates." In these patients, the high prevalence $(63 \%)$ of genotype 1 infection could be another factor accounting for hyporesponsiveness to interferon. This HCV strain is less sensitive to interferon than types 2 and 3.3 .3$. At present, it is not clear whether genotype 1 differs in terms of intrinsic sensitivity to interferon from other $\mathrm{HCV}$ genotypes. or whether it preferentially segregates with more prolonged infections and/or more advanced liver disease, another factor known to be associated with poor responsiveness to interferon. ${ }^{3.1}$

There was no correlation belween response to interferon and coinfection with HGV, a novel member of the Flaviridae family. which can be cotransmitted with clotting factor concentrates. ${ }^{2}$ In our patients. the overall prevalence of serum HGV-RNA was low $(8 \%)$. suggesting that this virus plays a marginal role in the hepatitis of hemophilic patients.

Finally, the low rates of primary responses $(30 \%)$ observed in our patients could have been due to inadequate initial doses of interferon therapy, which in turn could be another factor accounting for unsatisfactory long-term therapeutic results. However. results of studies in nonhemophilic patients suggest that the advantage of administering initial high doses is to increase durability of the responses, not to recruit more primary responses. In a prospective study, patients treated with initial doses of 6 million $U$ of interferon $\alpha$ for 4 months followed by a 3 million $U$ dose for 8 months had similar rates $(73 \%)$ of primary responses but higher rates of sustained responses $(42 \%$ vs $25 \%$ ) than patients treated with the same treatment schedule used for our patients. In our study, treatment was well tolerated; none of the patients developed inhibitors to the deficient clotting factors and only one (2\%) treatment had to be interupted because of severe flu-like symptoms occurring during the first 2 weeks of the study. For four patients $(8 \%$ ) the dose had to be reduced by $50 \%$ between months 3 and 6 because of the onset of moderate leukopenia, thrombocytopenial, or fatigue. These figures overlap with those for nonhemophilic patients treated by the same schedule of therapy, $\$, 5$

In conclusion, this study demonstrates that only $13 \%$ of anti-HIV seronegative hemophilic patients benefited longterm from prolonged interferon therapy. Since hemophilic patients with hepatitis $\mathrm{C}$ who escaped HIV infection have a long prospect 
of survival, they should be offered all chances for suppressing HCV. One approach for obtaining this could be to increase the durability of the response by administering high initial doses of interferon and treating with more cycles of interferon those patients in whom hepatitis relapsed after discontinuation of treatment.

\section{Appendix}

Members of the Hepatitis Study Group are as follows: A. Alberti. Clinica Medica 2, University of Padova; N. Ciavarella. M. Schiavoni. Hemophilia and Thrombosis Center, Policlinico Hospital, Bari; R. de Biasi, A. Rocino. Department of Hematology. Nuovo Pellegrini Hospital, Naples; G. Gamba. Department of Internal Medicine, University of Pavia, P.G. Mori. Pediatric Division. G. Gaslini Hospital. Genoa; G. Iannaccaro, G. Muleo. Hemophilia Center. Pugliese Hospital. Catanzaro; A. Russo, Epidemiology Unit, Aviano Cancer Center; R. Soffredini. Institute of Internal Medicine, University of Milan, IRCCS Maggiore Hospital, Milan.

\section{References}

1. Rumi MG. Colombo M. Gringeri A. Mannuci PM: High prevalence of antibody to hepatitis $C$ virus in multitransfused hemophiliacs with normal transaminase levels. Ann Intern Med $112: 379,1990$

2. Triemstra M. Rosendaal FR. Smit C. Van der Ploeg HM. Briet E: Mortality in patients with hemophilia. Changes in a Dutch population from 1986 to 1992 and 1973 to $1986 . A m n$ Imern Med 123:823.1995

3. Saracco G. Rosina F, Abate ML. Chiandussi L. Gallo V, Cerutti E. Di Napoli A, Solinas A, Deplano A. Tocco A, Cossu P. Chien D. Kuo G. Polito A. Weiner AJ, Houghton M, Verme G, Bonino F, Rizzetto M: Long-term follow-up of patients with chronic hepatitis $C$ treated with different doses of interferon- $\alpha 2 \mathrm{~b}$. Hepatology 18:1300, 1993

4. Poynard T, Bedossa P. Chevallier M, Mathurin P. Lemonnier C, Trepo C, Couzigou P. Payen JL. Sajus M. Costa JM. Vidaud M.
Chaput JC. and the Multicenter Study Group: A comparison of three interferon alfa- $2 \mathrm{~b}$ regimens for the long-term treatment of chronic non-A, non-B hepatitis. $N$ Engl I Med 332:1457. 1995

5. Chemelto L. Bonetti P. Cavalletto L. Talato F. Donadon V. Casarin P. Belussi F. Frezza M. Noventa F. Pontisso P. Benvegnu L. Casarin C. Alberti $A$, and the TriVeneto Viral Hepatitis Group: Randomized trial comparing three different regimens of alpha-2a-interferon in chronic hepatitis C. Heputology 22:700. 1995 6. Peerlinck K. Willems M, Sheng L. Nevens F. Fevery J, Yap SH, Vermylen J: Rapid clearance of hepatitis $C$ virus RNA in peripheral blood mononuclear cells of patients with clotting disorders and chronic hepatitis $C$ treated with alpha-2b interferon is not a predictor for sustained response to treatment. $B r . J$ Hacmatol 86:810. 1994

7. Telfer P. Devereux H, Colvin B. Hayden S. 
Dusheiko G. Lee C: Alpha interferon for hepatitis $\mathrm{C}$ virus infection in haemophilic patients. Hacmophilia 1:54. 1995

8. Hanley JP, Jarvis LM, Andrews J, Dennis R. Hajes PC. Piris J, Lee R, Simmonds P, Ludlam $C A$ : Interferon treatment for chronic hepatitis $\mathrm{C}$ infection in hemophiliacs. Influence of virus load, genotype, and liver pathology on response. Bloced $87: 1704.1996$

9. Eyster ME. Diamondstone LS, Lien JM. Ehmann WC. Quan S. Goedert JJ, for the Multicenter Hemophilia Cohort Study: Natural history of hepatitis $\mathrm{C}$ virus infection in multitransfused hemophiliacs: Effect of coinfection with human immunodeficiency virus. $J A I D S S$ $0: 602,1993$

10. Wright TL. Hollander H. Pu X. Held MJ. Lipson P, Quan S. Polito A. Thaler MM. Bacchetti P. Scharschmidt BF: Hepatitis $C$ in HIV-infected patients with and without AIDS: Prevalence and relationship to patient survival. Hepatology 20:1152, 1994

11. Marcellin P. Martinot-Peignoux M. Elias A. Branger $M$, Courtois $F$, Level $R$, Erlinger $S$. Benhamou JP: Hepatitis $C$ virus (HCV) viremia in human immunodeficiency virus-seronegative and seropositive patients with indeterminate $\mathrm{HCV}$ recombinant immunoblot assay. I Infect Dis 170:433, 1994

12. Rosendial FR. Smil C. Varekamp 1, BrockerVriends A. Suurmeijer TPBM. Briet E: AIDS and hacnrophilia: A study among Dutch haemophiliacs on the psychological impact of the AIDS threat, the prevalence of HIV antibodies and the adoption of measures to prevent HIV transmission. Haemestasis 18:73.1988 13. Gringeri A. Mannucei PM: National survey of HIV infection in Italian hemophiliacs. Ric Clin Lab /8:75. 1988

14. Evensen SA, Ulstrup J. Skaug K. Froland SS, Glomstein A, Rollag H: HIV infection in Norwegian haemophiliacs: The prevalence of antibodies against HIV in haemophiliacs trea- ted with lyophilized cryoprecipitate from volunteer donors. Eur.J Hematol 39:44. 1987 15. Reichard O, Foberg U, Fryden A. Mattsson L. Norkrans G. Sonnerborg A, Wejstal R, Yun $\mathrm{ZB}$, Weiland $\mathrm{O}$ : High sustained response rate and clearance of viremia in chronic hepatitis $\mathrm{C}$ after treatment with interferon- $\alpha 2 \mathrm{~b}$ for $\mathbf{6 0}$ weeks. Hepatology 19:2801994

16. Rumi MG. Colombo M, Romeo R, Colucci

G. Gringeri A. Mannucci PM: Serum hepatitis $B$ virus DNA detects cryptic hepatitis $B$ virus infections in multitransfused hemophiliac patients. Blood 75:16.54.1990

17. Rumi MG. Del Ninno E, Parravicini ML. Romeo R. Solfredini R. Donato MF, Zahm F, Colombo $M$ : Long-term titrated recombinant interferon- $(x) 2 \mathrm{a}$ in chronic hepatitis $\mathrm{C}$ : A randomized controlled trial. J Viral Hep 2:73. 199.5

18. Detmer J, Lagier R, Flym J, Zayati C. Kolberg J, Collins M, Urdea M, SanchezPescador R: Accurate quantification of $\mathrm{HCV}$ RNA from all $\mathrm{HCV}$ genotypes using branched-DNA (bDNA) technology. I Clin Microbiol 34:901.1996

19. Tagger A, Ribero ML, Tremolada F, Casarin C. Rapicetta M, Cristiano K. Fasola M. Pregliasco F. Profeta ML: Hepatitis C viremia and serologic profile in post-transfusion nonA, non-B hepatitis, in Nishioka K, Suzuki $H$, Mishiro S, Oda T (eds): Viral Hepatitis and Liver Disease. Tokvo. Japan. Springer-Verlag. 1994.p 56.5

20. Linnen J. Wages J. Zhang-Keck ZY. Fry KE, Krawezynski KZ. Alter H. Koonin E, Gallagher M. Alter M. Hadziyannis S, Karayiannis P. Fung K. Nakatsuji Y, Shih JW, Young L, Piatak M, Hoover C. Fernandez J, Chen S, Zou JC, Morris T. Hyams KC. Ismay S, Lifson JD, Hess G. Foung SKH. Thomas H, Bradley D. Margolis $H$, Kin JP: Molecular cloning and disease association of hepatitis $G$ virus: A transfusiontransmissible agent. Science 271:505, 1996 
21. Tigaricllo G. Pontisso P. Divoli PG. Ruvoletto MG. Traldi A. Alberti A: Hepatitis C virus genotypes and severity of chronic liver disease in haemophiliacs. $\mathrm{Br} / \mathrm{H}$ (to'mat 91:708. 1995

22. Makris M. Preston FE, Rosendaal FR. Underwood JCE. Rice KM. Triger DR: The natural history of chronic hepatitis $\mathrm{C}$ in haemophiliacs. Br.J Hacmalol 94:740. 1996

23. Mannucci PM: Effects of factor VIII concentrates on the immune system of patients with hemophilia. Thromb Haemostas $74: 4,37$. 1995

24. Jarvis LM. Watson HG, McOmish F. Peutherer JF. Ludlaun CA. Simmonds P: Frequent reinfection and reactivation of hepatitis $\mathrm{C}$ virus genotypes in multitransfused hemophiliacs. I Infect Dis 170:10/8. 1997 25. Devereux H. Telfer P. Brown D. Morris A. Dusheiko G. Emery V. Lee C: Longitudinal genotype analysis and quantification of hepatitis $\mathrm{C}$ virus in haemophilic patients receiving interferon-a therapy. I Viral Hop 3.43, 1996

26. Yamada G. Takatani M. Kishi F. Takahashi M. Doi T. Tsuji T. Shin S. Tanno M. Urdea MS. Kolberg JA: Efficacy of interferon alfa therapy in chronic hepatitis $C$ patients depends primarily on hepatitis C virus RNA level. Heparology 22:135/.1995

27. Nousbaum JB, Pol S. Nalpas B. Landais P. Berthelot P. Brechot C. the Collaborative Study Group: Hepatitis C virus type $1 \mathrm{~b}$ (II) infection in France and Italy. Am Imtem $M e d / 22: 161$. 199.5

28. Rumi MG, Del Nimo E. Parravicini ML, Romeo R, Soffredini R, Donato MF. Wilber J, Russo A. Colombo M: A prospective randomized trial comparing lymphoblastoid to recombinant alpha $2 \mathrm{a}$ interferon as therapy of chro- nic hepatitis C. Hepolology 24:1.360. 1996 29. Pagliaro L. Craxi A. Cammaà C. Tiné F. Di Matco V. Lo lacono O. Almasio P: Interferon-ce for chronic hepatitis $C$ : An analysis of pretreatment clinical predictors of response. Hepafology 19:820. 1994

30. Fletcher ML. Trowell JM. Craske J, Pavier K. Rizza CR: Non-A, non-B hepatitis after transfusion of factor VIII in infrequently treated patients. $\mathrm{Br}$ Med.I 287:17.54. 1983

31. Tsubota A. Chayama K. Ikeda K. Yasuji A. Koida I. Saitoh S. Hashimoto M. Wasaki S. Kobayashi M, Hiromitsu K: Factors predictive of response to interferon- $\alpha$ therapy in hepatitis $\mathrm{C}$ virus infection. Heparology 19:108S8, $199+4$

32. Matsumoto A. Tanaka E, Suzuki T, Ogata H. Kiyosawa K: Viral and host factors that contribute to efficacy of interferon- $\alpha$ 2a therapy in patients with chronic hepatitis C. Dis Dis Sci 39:1273. 1994

33. Telter PT, Devereux H, Savage K, Scolt F. Dhillon AP. Dusheiko G, Lee CA: Chronic hepatitis $C$ virus infection in haemophilic patients: Clinical significance of viral genotype. Thromb Hacmostas 74:1259.1995

34. Zein NN. Rakela J. Krawiu EL. Reddy KR. Tominaga T. Persing DH. the Collaborative Sudy Group: Hepatitis C virus genotypes in the United States: Epidemiology, pathogenicity, and response to interferon therapy. $\mathrm{I} m \mathrm{~m}$ Imern Med 125:0.34. 1996

35. Fattovich G. Giustina G, Favarato S. Ruol A. Investigators of the Ialian Association for the Siudy of the Liver: A survey of adverse events in 11241 patients with chronic viral hepatitis

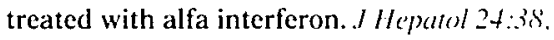
1996 


\title{
High prevalence of serum cryoglobulins in multitransfused hemophilic patients with chronic hepatitis $\mathbf{C}$
}

\author{
E. Santagostino, M. Colombo, D. Cultraro, M. Muça-Perja, \\ A. Gringeri, P.M. Mannucci \\ Angelo Bianchi Bonomi Hemophilia and Thrombosis Center and the Department \\ of Internal Medicine, IRCCS Maggiore Hospital and University of Milan, Milan, Italy.
}

Blood 92:516-519, 1998. 


\section{Abstract}

The prevalence, clinical relevance, and risk factors of serum cryoglobulins in hemophilic patients with chronic hepatitis $\mathrm{C}$ virus ( $\mathrm{HCV}$ ) infection are unknown. We studied 135 consecutive hemophilic patients (median age, 31 years; range, 10 to 69 years) with chronic hepatitis $\mathrm{C}$, exposed to the virus for 10 to 41 years. A total of 67 patients were coinfected with the human immunodeficiency virus (HIV), and 3 (2\%) had signs of cirrhosis. Serum samples were tested for the presence of cryoglobulins, hepatitis B virus (HBV) markers, including HBV-DNA by hybridization assay, and antibody to HCV by enzyme immunoassay (EIA). Serum HCV-RNA was tested by polymerase chain reaction and typed with a hybridization technique. Samples were also tested for antitissue antibodies, immunoglobulins, rheumatoid factor, and $\mathrm{C}_{3}$ and $\mathrm{C}_{4}$ proteins of complement. Forty-two hemophiliacs $(31 \%)$ circulated cryoglobulins (median levels, $166 \mathrm{mg} / \mathrm{L}$; range, 66 to 480 ) predominantly type III (62\%; and $29 \%$ type II). None of the patients had clinical signs or symptoms of systemic vasculitis. Cryoglobulinemic patients had more often serum HCV-RNA $(95 \% \vee 80 \%, \mathrm{P}<.05)$, rheumatoid factor $(20 \% \vee 6 \%, \mathrm{P}<.05)$, higher levels of $\mathrm{IgG}$ $(2,354 \pm 682 \mathrm{mg} / \mathrm{dL}$ v $1,928 \pm 557 \mathrm{mg} / \mathrm{dL}, \mathrm{P}<.0005)$ and $\operatorname{IgM}(323 \pm 226 \mathrm{mg} / \mathrm{dL} v$ $244 \pm 243 \mathrm{mg} / \mathrm{dL}, \mathrm{P}<.05)$, and lower levels of serum $\mathrm{C}_{4}(19 \pm 8 \mathrm{mg} / \mathrm{dL} \vee 24 \pm 8$ $\mathrm{mg} / \mathrm{dL}, \mathrm{P}<.05$ ) than patients without cryoglobulins. The risk of producing cryoglobulins was greater for 114 patients circulating HCV-RNA than for 21 nonviremic patients (odds ratio $[O R]=4.9,95 \%$ confidence interval $[\mathrm{CI}]=1.1$ to 22.0 ) and for the 31 patients with longer exposure to $\mathrm{HCV}$ (more than 26 years) than for the 24 patients with shorter ( 17 years or less) exposure ( $\mathrm{OR}=4.495 \% \mathrm{CI}=1.1$ to 18.0 ). In conclusion a large number of multitransfused hemophiliacs with chronic HCV infection circulated serum cryoglobulins but none had clinical signs or symptoms of vasculitis. The risk of developing cryoglobulins parallels the duration of exposure to HCV.

\section{Introduction}

Serum cryoglobulins, consisting of polyclonal IgG and either polyclonal or monoclonal (IgM) rheumatoid factor (mixed cryoglobulinemia) have been detected in $19 \%$ to $54 \%$ of patients with chronic hepatitis C virus (HCV) infection. ${ }^{1-5}$ In $10 \%$ to $42 \%$ of the cases cryoglobulins were associated with a systemic vasculitic disorder with such clinical signs as palpable purpura, arthropathy, peripheral neuropathy, or Raynaud phenomenon.,.6 The prevalence, clinical relevance, and risk factors of serum cryoglobulins in patients with chronic hepatitis $\mathrm{C}$ are not well established. Cross-sectional studies of $\mathrm{HCV}$-infected patients showed a predominance of serum cryoglobulins in women, older patients, and 
patients with longlasting and severe hepatitis. ${ }^{6.8}$ Other studies found a correlation between serum cryoglobulins and infection with HCV genotype $2 \mathrm{a} / \mathrm{c}$," genotype $1 \mathrm{~b}, 10$ or any genotype." Studying serum cryoglobulins in hemophilic patients with chronic hepatitis $\mathrm{C}$ may be clinically important because the prevalence and clinical significance of cryoglobulins in these patients are unknown. Moreover, multitransfused hemophiliacs offer a unique model to evaluate the relationship between cryoglobulins and the duration of hepatitis C. The duration of hepatitis $\mathrm{C}$ can be established precisely in these patients, because they have beenexposed to $\mathrm{HCV}$ at the time of their first infusion with non-virus-inactivated clotting factor concentrates.12-14 Therefore, we chose to study 135 multitransfused hemophilic patients with chronic hepatitis $\mathrm{C}$ who were consecutively recruited in this study during their periodic medical check-up at the Hemophilia Center (Milan, Italy).

\section{Materials and Methods}

Patients. From June 1995 to July 1996, we studied 135 consecutive anti-HCV antibody-positive hemophiliacs (134 men; 123 with hemophilia A and 12 with hemophilia B). who were regularly attending the Angelo Bianchi Bonomi Hemophilia and Thrombosis Center (Milan, Italy) for their annual medical check-up. The duration of $\mathrm{HCV}$ infection was calculated assuming that the first infusion with blood, plasma, or non-virus-inactivated concentrates manufactured from large pools of plasma had transmitted the virus C. 12.13 According to this criterion, 128 hemophiliacs have been infected with $\mathrm{HCV}$ for 10 to 41 years (median, 23 years). Their main epidemiological and clinical features are shown in Table 1. In each patient serum alanine aminotransferase (ALT) values had been measured every year since 1979 and were classified as persistently normal (<40 U/L), intermittently elevated, and persistently elevated. HCV genotype distribution was $1 \mathrm{a}$ in $39 \%, 1 \mathrm{~b}$ in $35 \%$, la plus $\mathrm{lb}$ in $3 \%, 2 \mathrm{~b}$ in $4 \%, 2 \mathrm{a} / \mathrm{c}$ in $2 \%, 3$ in $10 \%, 4$ in $2 \%$, and not performed in $5 \%$. Sixty-seven hemophiliacs $(50 \%)$ had serum antibody to human immunodeficiency virus (anti-HIV) for 11 to 14 years (median, 13 years); 35 $(52 \%)$ had signs of disease progression, with $\mathrm{CD}_{4}$ cell counts less than $200 / \mathrm{cmm}$ and/or full-blown acquired immunodeficiency syndrome. These patients were receiving antiretroviral therapy. None of the patients had received treatment with interferon or steroids in the previous 12 months.

Study Profile. Clinical history and physical examination, liver and kidney function, and routine chemistry tests were obtained in all patients. Special attention was given to the search for signs and symptoms of cirrhosis and for cryoglobulinemic syndrome. Cirthosis was diagnosed clinically on the basis of laboratory signs of liver failure, ie, platelet count less than $150.000 / \mathrm{mL}$, serum albumin less than $3.5 \mathrm{~g} / \mathrm{L}$, serum cholinesterase activity less than $4.500 \mathrm{U} / \mathrm{L}$. endoscopic signs of portal hypertension (presence of esophageal varices and hypertensive gastropathy), and/or by abdominal ultrasound 
(irregular margins of the liver, dilated portal vein, and splenomegaly). All patients were also examined for signs and symptoms referable to serum cryoglobulins, ie, palpable purpura, active or healed skin ulcers, peripheral neuropathy, Ray-naud's phenomenon, sicca syndrome, or re-nal complications. Joint pain or damage were not considered among possible symptoms of cryoglobulinemia be-cause hemophilic arthropathy may be a confounder.

Serum Assays. Cryo-globulins were precipitated from serum stored for up to 8 days at $4^{\circ} \mathrm{C}\left(0.1 \mathrm{~g} / \mathrm{L}\right.$ sodium azide). The precipitates were washed five times at $4^{\circ} \mathrm{C}$ with 0.15 $\mathrm{mol} / \mathrm{L} \mathrm{NaCl}$. A fraction of washed cryoglobulins was then diluted in $0.1 \mathrm{~mol} / \mathrm{L} \mathrm{NaOH}$, and concentration was measured by reading the absorbance at $280 \mathrm{~nm}$. Values less than $50 \mathrm{mg} / \mathrm{L}$ were considered negative. Washed cryoglobulins were tested for lg composition by immunoblotting according to Musset et al. ${ }^{15}$ According to Brouet et al, ${ }^{16}$ cryoglobulins were classified as type 11 (if rheumatoid factor was monoclonal) or type III (if rheumatology factor was polyclonal). Serum antinuclear antibodies, antimitochondrial antibodies, antismooth muscle antibodies, and anti-liver-kidney-micro-some antibodies were tested for by indirect immunofluorescence. A titer equal or greater than 1:40 was considered positive. The serum $\mathrm{Ig}$, rheumatoid factor, and $C_{3}$ and $C_{4}$ complement fraction levels were measured by routine nephelometric assays. The upper limit of the normal levels of the rheumatoid factor was $60 \mathrm{IU} / \mathrm{mL}$.

Anti-HCV was detected with a third-generation enzyme-linked immunosorbent assay (ELISA; Ortho Diagnostics System, Raritan, NJ). HCV-RNA was detected by a polymerase chain reaction (PCR) technique (Amplicor, Roche Diagnostics, Nutley, NJ). HCV genotypes were determined by a reverse hybridization assay (LiPA; Innogenetics, Brussels, Belgium). ${ }^{17}$ Hepatitis B virus (HBV)-related markers were detected by using commercially available kits (Abbott Laboratories, North Chicago, IL). HBV-DNA was detected by a capture hybridization assay (Digene, Beltsville, MD). Anti-HIV-1 was detected by using a commercially available ELISA and confirmed by Western blot (Abbott Laboratories).

Statistical Analysis. Continuous variables were expressed as mean values and standard deviations. Discrete variables were expressed as median values and ranges. Categorical values were expressed as frequency and percent values. The $t$-test was used to compare means. Logarithmic transformation was used when distribution was not normal. Logistic regression was used to calculate the risk of cryoglobulinemia in patients with serum HCV-RNA, HIV coinfection, and different duration of HCV infection. The periods of $\mathrm{HCV}$ infection duration were chosen on the basis of the distribution quartiles of the cohort ( 10 to 17,18 to 21,22 to 26 , and greater than 26 years), and the first quartile was used as reference. The results were expressed as odds ratio and $95 \%$ confidence intervals $(\mathrm{CI})$. 


\section{Results}

Forty-1wo patients ( $31 \%)$ circulated cryoglobulins, with concentrations ranging between 66 and $480 \mathrm{mg} / \mathrm{L}$ (median, $166 \mathrm{mg} / \mathrm{L}$ ). Cryoglobulins were type III in 26 patients $(62 \%)$ and type II in $12(29 \%)$. In 4 patients (9\%) cryoglobulins were not typed. Although in patients with type-II cryoglobulin there was a tendency for less severe liver disease (as expressed by the prevalence of persistently elevated ALT), differences were not statistically significant ( $35 \%$ v $50 \%$ in type III). Age, severity of hemophilia, pattern of serum ALT, preva-

Table 1. Epidemiological and clinical features of the 135 hemophilic patients with chronic hepatitis $\mathrm{C}$ according to the presence or absence of serum cryoglobulins

\begin{tabular}{|c|c|c|c|}
\hline Features & $\begin{array}{l}\text { All patients } \\
n=135\end{array}$ & $\begin{array}{l}\text { Cryo. } \\
\text { globulins }(t) \\
n=42\end{array}$ & $\begin{array}{l}\text { Cryo- } \\
\text { globulins (-) } \\
n=93\end{array}$ \\
\hline Age, median (range) & $31(10-69)$ & $32(14-69)$ & $31(10-66)$ \\
\hline \multicolumn{4}{|l|}{ Hemophilia } \\
\hline Severe & $112(83 \%)$ & $38(90 \%)$ & $74(80 \%)$ \\
\hline Mild/moderate & $23(17 \%)$ & $4(10 \%)$ & $19(20 \%)$ \\
\hline \multicolumn{4}{|l|}{ Serum ALT } \\
\hline Persistently normal & $14(10 \%)$ & $2(4 \%)$ & $12(13 \%)$ \\
\hline Intermittently high & $69(51 \%)$ & $20(48 \%)$ & $49(53 \%)$ \\
\hline Persistently high & $52(39 \%)$ & $20(48 \%)$ & $32(34 \%)$ \\
\hline Cirrhosis & $3(2 \%)$ & 0 & $3(2 \%)$ \\
\hline
\end{tabular}

Abbreviations: NS, not significant; ALT, alanine aminotransferase lence of cirrhosis, antitissue antibodies, anti$\mathrm{HCV}, \mathrm{HBsAg}, \mathrm{HBV}-$ DNA, anti-HIV, and HIV disease progression were similar in patients with or without serum cryoglobulins (Table 1 and 2). There were no differences in HCV genotype distribution between cryoglobulinemic and noncryoglobulinemic patients (data not shown).

Conversely, prevalence of serum HCV-RNA $(95 \% \vee 80 \%, \mathrm{P}<.05)$ and of rheumatoid factor $(20 \% \vee 6 \%$, $\mathrm{P}<.05)$, mean serum levels of $\operatorname{lgG}(2,354 \pm 682 \mathrm{mg} / \mathrm{dL} \vee 1,928 \pm 557 \mathrm{mg} / \mathrm{dL}$, $\mathrm{P}<.0005)$, and $\operatorname{IgM}(323 \pm 226 \mathrm{mg} / \mathrm{dL} \vee 244 \pm 243 \mathrm{mg} / \mathrm{dL}, \mathrm{P}<.05)$ were higher in patients with cryoglobulins than in those without. Instead, the mean serum levels of $\mathrm{C}_{4}$ were lower in the cryoglobulinemic patients $(19 \pm 8 \mathrm{mg} / \mathrm{dL} \vee 24 \pm 8 \mathrm{mg} / \mathrm{dL}$, $\mathrm{P}<.05$; Table 2). None of the patients had or has had signs of palpable purpura, healed or active skin ulcers, peripheral neuropathy, kidney failure, sicca syndrome, or Raynaud phenomenon. In patients with serum HCV-RNA the risk of developing serum cryoglobulins was $4.9(95 \% \mathrm{CI}, 1.1$ to 22$)$ times that for nonviremic patients and it remained significantly higher after adjusting for HIV infection (Table 3). Compared with patients with 10 to 17 years exposure to $\mathrm{HCV}$, the risk of developing cryoglobulins was $2.4(95 \% \mathrm{Cl}, 0.6$ to 10.8$)$ for patients with 18 to 21 years exposu- 
Table 2. Virological and immunological features of the 135 hemophilic patients with chronic hepatitis $\mathrm{C}$ according to the presence or absence of serum cryoglobulins

$\begin{array}{lllll}\text { Serum Markers } & \begin{array}{l}\text { All patients } \\ (n=135)\end{array} & \begin{array}{l}\text { Cryoglobulins }(+) \\ (n=42)\end{array} & \begin{array}{l}\text { Cryoglobulins }(-) \\ (n=93)\end{array} & \begin{array}{l}\text { P. Value * } \\ \text { Anti-HCV }\end{array} \\ \text { HCV-RNA } & 135(100 \%) & 42(100 \%) & 93(100 \%) & \text { NS } \\ \text { HBSAg } & 114(84 \%) & 40(95 \%) & 74(80 \%) & <.05 \\ \text { HBV-DNA } & 9(7 \%) & 7(17 \%) & 2(2 \%) & \text { NS } \\ \text { Anti-HIV } & 14(10 \%) & 2(5 \%) & 12(13 \%) & \text { NS } \\ \text { Antitissue antibodies (titer } \geq 1: 40) & 31 / 123(25 \%) & 8 / 38(21 \%) & 23 / 85(27 \%) & \text { NS } \\ \text { Rheumatoid factor }>60 \mathrm{Ul} / \mathrm{ML} & 13 / 129(10 \%) & 8 / 40(20 \%) & 5 / 89(6 \%) & <.05 \\ \operatorname{lgG}(\mathrm{mg} / \mathrm{dL})^{\circ} & 2,066 \pm 630 & 2,354 \pm 682 & 1.928 \pm 557 & <.0005 \\ \operatorname{lgM}(\mathrm{mg} / \mathrm{dL})^{\circ} & 269 \pm 240 & 323 \pm 226 & 244 \pm 243 & <.05 \\ C_{4}(\mathrm{mg} / \mathrm{dL})^{\circ} & 22 \pm 8 & 19 \pm 8 & 24 \pm 8 & <.05\end{array}$

Abbreviations: NS, not significant; * Cryoglobulins (+) vs Cryoglobulins (-)

- Data are mean \pm standard deviation

re to $\mathrm{HCV}, 3.7(95 \% \mathrm{Cl}$, 1.0 to 14.4) for those with 22 to 26 years exposure, and 4.4 (95\% CI, 1.1 to 18.0) for those with longer than 26 years exposure. A similar trend was observed after adjusting for HIV infection. The odds ratio of developing serum cryoglobulins in antiHIV-positive pa-tients was $1.6(95 \% \mathrm{CI}, 0.8$ to
Table 3. Risk of developing cryoglobulins in relation to serum HCV-RNA, length of exposure to HCV, and serum anti-HIV in hemophiliacs

$\begin{array}{clll}\begin{array}{c}\text { Risk factor } \\ \text { Patients }\end{array} & \begin{array}{l}\text { No. of } \\ \text { Odds Ratio } \\ (95 \% \mathrm{Cl})\end{array} & \begin{array}{l}\text { Odds Ratio } \\ \text { Adjusted for HIV } \\ (95 \% \mathrm{CI})\end{array} \\ \begin{array}{l}\text { HCV exposure } \\ 10-17 \mathrm{yr}\end{array} & 114 & 4.9(1.1-22.0) & 4.5(1.0-20.7) \\ 18-21 \mathrm{yr} & 27 & 1 & 1 \\ 22-26 \mathrm{yr} & 46 & 2.4(0.6-10.8) & 2.3(0.5-10.3) \\ >26 \mathrm{yr} & 31 & 3.7(1.0-14.4) & 3.4(0.9-13.8) \\ \text { Anti-HIV }(+) & 67 & 4.4(1.1-18.0) & 4.0(0.9-17.2) \\ & & 1.6(0.8-3.2) & -\end{array}$

3.2) compared with anti-HIV-seronegative patients (Table 3). Serum levels of cryoglobulins and type of cryoglobulin distribution were similar in anti-HIV-positive and negative patients (data not shown). Anti-HIV-positive patients had higher serum levels of $\operatorname{IgG}(2,406 \pm 608 \mathrm{mg} / \mathrm{dL} \vee 1,720 \pm 435 \mathrm{mg} / \mathrm{dL}, \mathrm{P}<.001)$ and $\operatorname{IgM}(295 \pm$ $208 \mathrm{mg} / \mathrm{dL} \vee 243 \pm 267 \mathrm{mg} / \mathrm{dL}, \mathrm{P}<.05)$ than anti-HIV seronegative patients. 


\section{Discussion}

This is the first study evaluating the prevalence, clinical relevance, and risk factors of serum cryoglobulins in multitransfused hemophilic patients with chronic $\mathrm{HCV}$ infection. Approximately one third of the patients circulated serum cryoglobulins, which were predominantly type III with polyclonal rheumatoid factor. Further confirming the strict association between HCV replication and appearance of serum cryoglobulins, serum HCV-RNA was more often detected in patients with cryoglobulins than in those without $(95 \%$ v $80 \%, \mathrm{P}<.05)$. Interestingly, despite the relatively high serum levels of circulating cryoglobulins, none of the patients had clinical signs or symptoms of systemic vasculitic disorders.

Three previous studies in nonhemophilic patients with HCV-related chronic hepatitis or cirrhosis found similar rates $\left(35 \%\right.$ to $37 \%$ ) of serum cryoglobulins. ${ }^{2-4}$ Another study reported a $54 \%$ rate in patients with chronic hepatitis C. 1 These studies showed a tendency for higher rates to occur in women, older patients, and those with longlasting HCV-related infection or cirrhosis. Perhaps the fact that all except one of our hemophilic patients were men and had a median age of 31 years, and that only few of them had clinical signs of cirrhosis, would account for the relatively low rate $(31 \%)$ of serum cryoglobulins that we observed. Studies in nonhemophilic patients suggested an association between serum cryoglobulins and genotype $2 \mathrm{a} / \mathrm{c}$ or $1 \mathrm{~b}$ of HCV.,10 We could not assess whether any HCV genotype was pathogenetically relevant as to cryoglobulinemia, because most of our patients were chronically infected with the coagulation concentrate-related genotype 1 of HCV.18-20 The low rates of genotype $2 \mathrm{a} / \mathrm{c}$ could be another factor contributing to the relatively low rates of serum cryoglobulin found in these patients. Finally, it must be pointed out that this study was not prospective and was based on the evaluation of one serum sample only. It is possible that cryoglobulins may have appeared and disappeared over time in hemophilic patients with hepatitis $\mathrm{C}$.

The most important finding of this study was the positive correlation existing between duration of hepatitis $\mathrm{C}$ and risk of producing serum cryoglobulins. The existence of such a correlation is difficult to show in nonhemophilic patients, because most of them have community-acquired hepatitis in which the starting point of infection is difficult to assess. Another important finding was the absence of clinical signs of systemic vasculitis in hemophiliacs with cryoglobulins. These data contrast with those obtained in nonhemophilic patients, showing signs and symptoms of vasculitis in $10 \%$ to $50 \%$ of patients. 2.6 .20 .21 Perhaps such factors as the young age of our patients and the male sex, which seem to influence negatively the production of serum cryoglobulins, are also influencing the risk of vasculitis. Preliminary data indicate that patients infected with $\mathrm{HCV}$ later in life are at higher risk of cirrhosis 
and liver cancer than those infected earlier.22-24 Assuming that this holds true also for the risk of developing serum cryoglobulin-related sequelae, hemophiliacs could be at low risk of vasculitis because they were predominantly infected by HCV early in life at the time of the first infusion with blood products.

Similar prevalences and amounts of serum cryoglobulins were found in patients with serum anti-HIV and those without, indicating that there is no obvious association between HIV infection and cryoglobulins. However, association studies in HIVinfected hemophilic patients should be interpreted with caution. HIV/HCV-coinfected hemophiliacs could have more serious HCV-related sequelae than HIV-uninfected patients, but this is difficult to show by retrospective studies because of the shortened survival of patients with serum anti-HIV.25.26

In conclusion, a significant number of hemophilic patients with chronic hepatitis $\mathrm{C}$ circulated cryoglobulins, but they had no clinical sign of vasculitis. Because the risk of developing serum cryoglobulins seems to increase with the duration of exposure to $\mathrm{HCV}$, a prospective study is necessary to establish whether or not in these patients serum cryoglobulinemia will remain asymptomatic or become a clinically relevant complication of HCV infection.

\section{References}

1. Lunel F, Musset L, Cacoub P, Frangeul L. Cresta P, Perrin M, Grippon P, Hoang C, Piette JC, Huraux JM. Opolon P: Cryoglobulinemia in chronic liver disease: Role of hepatitis $C$ virus and liver damage. Gastroenterology 106:1291, 1994

2. Pawlotsky JM, Ben Yahia M, Andre C, Voisin $M C$, Intrator L, Roudot-Thoraval F, Deforges L. Duvoux C. Zafrani ES, Duval J, Dhumeaux D: Immunological disorder in $\mathrm{C}$ virus chronic active hepatitis: A prospective case-control study. Heparology 19:841, 1994

3. Van Thiel DH, Fagiuoli S. Caraceni P, Wright HI. Nadir A, Gavaler JS, Zuhdi N:

Cryoglobulinemia: A cause for false negative polymerase chain reaction results in patients with hepatitis $\mathrm{C}$ virus positive chronic liver disease. I Hepatol 22:464. 1995

4. Tanaka K, Aiyama T, Imai J. Morishita Y,
Fukatsu T, Kakumu S: Serum cryoglobulin and chronic hepatitis $\mathrm{C}$ virus disease among Japanese patients. Am I Gastroenterol 90:1847. 1995

5. Wong SV, Egner W. Elsey T. Brown D, Alexander GJM: Incidence, character and clinical relevance of mixed cryoglobulinaemia in patients with chronic hepatitis $\mathrm{C}$ virus infection. Clin Exp Immunol 104:25, 1996

6. Cacoub P, Frangeul L, Lunel F, et al: Mixed cryoglobulinemia and hepatitis $C$ virus infection: A multivariate analysis. Eur J Intern Med 6.54a. 1995 (abstr; suppl)

7. Hartmann H, Schott P, Polzien F. Mihm S, Ramadori G: Cryoglobulinemia in chronic hepatitis $\mathrm{C}$ virus infection: Is cross-reactivity of anti-HCV IgM to IgG a pathogenetic mechanism? J Hepatol 25:WP 1/05. 1995 (abstr; suppl I)

8. Kakumu S. Alyama T, Yoshioka K, et al: 
Cryoglobulinemia and chronic hepatitis $\mathrm{C}$ virus disease among Japanese patients. Inern Hepatol Commun 3:S49. 1995 (suppl)

9. Zignego AL, Ferri C, Giannini C, Monti M. La Civita L, Careccia G, Longobardo G, Lombardini F, Bombardieri S, Gentilini P: Hepatitis $C$ virus genotype analysis in patients with type II mixed cryoglobulinemia. Ann Intern Med 124:31, 1996

10. Galli M, Zehender G, Monti G, Ballare M, Saccardo F, Piconi S, De Maddalena C, Bertoncelli MC. Rinaldi G, Invernizzi F, Monteverde A: Hepatitis C virus RNA in the bone marrow of patients with mixed cryoglobulinemia and in subjects with non-cryoglobulinemia chronic hepatitis type C. J Infect Dis $71.672,1995$

11. Pawlotsky JM, Roudot-Thoraval F, Simmonds P. Mellor J, Ben Yahia MB, Andre C, Voisin MC, Intrator L, Zafrani ES, Duval J. Dhumeaux D: Extrahepatic immunologic manifestations in chronic hepatitis $\mathrm{C}$ and hepatitis $\mathrm{C}$ virus serotypes. Ann Intern Med 122:169, 1995

12. Fletcher ML. Trowell JM, Craske J, Pavier K, Rizza CR: Non-A, non-B hepatitis after transfusion of factor VIII in infrequently treated patients. Br Med J 287:/754, 1983

13. Kernoff PBA, Lee CA, Karayiannis $P$, Thomas HC. High risk of non- $A$, non-B hepatitis after a first exposure of volunteer or commercial clotting factor concentrates: Effect of prophylactic immune serum globulin. $B r . J$ Haematol 60:469, 1985

14. Watson HG, Ludlam CA, Rebus S, Zhang LQ. Peutherer JF, Simmonds P: Use of several second generation assays to determine the true prevalence of hepatitis $\mathrm{C}$ infection in haemophiliacs treated with non-virus inactivated factor VIII and IX concentrates. Br I Haematol 80:514. 1992

15. Musset L, Diemert MC. Taibi F. Thi Huong Du L, Cacoub P Leger JM, Boissy G, Gaillard O, Galli J: Characterization of cryoglobulins by immunoblotting. Clin Chem 38:798, 1992

16. Brouet JC, Clauvel JP, Danon F, Klein M, Seligmann M: Biologic and clinical significance of cryoglobulins. Am .J Med 57:775, 1974

17. Stuyver L, Rudi R, Wyseur A, Duhamel M, Vanderborght B, Van Heuverswyn H, Maertens $\mathrm{G}$ : Typing of hepatitis $\mathrm{C}$ virus isolates and characterization of new subtypes by using a line probe assay. I Gen Virol 74:1093, 199.3

18. Preston FE. Jarvis LM, Makris M, Philp L, Underwood JCE, Ludlam CA, Simmonds P: Heterogeneity of hepatitis $C$ virus genotypes in hemophilia: Relationship with chronic liver disease. Blood 85:1259. 1995

19. Rumi MG, Santagostino E, Morfini M, Gringeri A. Tagariello G, Chistolini A, Pontisso P, Tagger A, Colombo M, Mannucci PM, and the Hepatitis Study Group of the Association of Italian Hemophilia Centers: A multicenter controlled, randomized, open trial of interferon a2b treatment of anti-human immunodeficiency virus-negative hemophilic patients with chronic hepatitis C. Blood 89:3529, 1997 20. Gorevic PD, Kassab HJ, Levo Y, Kohn R, Meltzer M, Prose PH, Franklin EC: Mixed cryoglobulinemia: Clinical aspects and long-term follow-up of 40 patients. Am J Med 69:287, 1980

21. Monti G, Galli M, Invernizzi F, Pioltelli P, Saccardo F, Monteverde A, Pietrogrande M, Renoldi P, Bombardieri S, Bordin G, Candela M, Ferri C, Gabrielli A, Mazzaro C, Migliaresi S, Mussini C, Ossi E, Quintiliani L, Tirri G, Vacca A: Cryoglobulinaemias: A multi-centre study of the early clinical and laboratory manifestations of primary and secondary disease. $Q J$ Med 88:1/5, 1995

22. Tradati F, Colombo M, Mannucci PM, Rumi MG, De Fazio C, Gamba G, Ciavarella N, Rocino A, Morfini M, Scaraggi A, Taioli E, and The Study Group of the Association of Italian Hemophilia Centers: A prospective multicenter study of hepatocellular carcinoma in Italian 
hemophiliacs with chronic hepatitis C. Blood 91:1173. 1998

23. Poynard T, Bedossa P, Opolon OPSVIRC, METAVIR, CLINIVIR, and DOSVIRC groups: Natural history of liver fibrosis progression in patients with chronic hepatitis C. Lancet 349:825, 1997

24. Darby SC, Ewart DW, Giangrande PLF, Spooner RJD, Rizza CR, Dusheiko GM, Lee CA. Ludlam CA, Preston FE, for the UK Haemophilia Centre Directors' Organisation: Mortality from liver cancer and liver disease in haemophilic men and boys in UK given blood products contaminated with hepatitis C. Lancet 350:1425. 1997

25. Triemstra M, Rosendaal FR, Smit $C$, Van del Ploeg HM. Briet E: Mortality in patients with hemophilia. Changes in a Dutch population from 1986 to 1992 and 1973 to 1986 . Am $/ \mathrm{mtern}$ Med 123:823,1995

26. Chorba TL, Holman RC, Strine TW, Clarke MJ, Evat BL: Changes in longevity and death among persons with hemophilia A. Am.J Hematol 45:1/2, 1994 


\section{Chapter 3}

\section{HIV infection in hemophiliacs}

- Factors associated with progression to AIDS and mortality in a cohort of HIV-infected patients with hemophilia followed up since seroconversion.

Cellular and Molecular Biology 41: 371-380, 1995

- Hemophilia and nonprogressing human immunodeficiency virus type 1 infection.

Blood 89: 191-200, 1997

- C-C chemokines, pivotal in protection against HIV type 1 infection.

Proceeding of the National Academy of Sciences

USA 95: 3857-3861, 1998 


\section{Factors associated with progression to AIDS and mortality in a cohort of HIV-infected patients with hemophilia followed up since seroconversion}

E. Santagostino, A. Gringeri, D. Cultraro, F. Tradati, L. Siracusano,

A. Marinoni and P.M. Mannucci

A. Bianchi Bonomi Hemophilia and Thrombosis Center, Institute of Internal Medicine, IRCCS Maggiore Hospital, University of Milan, Milan, Italy

Cellular and Molecular Biology 41:371-380, 1995 


\section{Abstract}

Progression to AIDS and death were evaluated in 112 patients, 84 with hemophilia $A$ and 28 with hemophilia B. Seroconversion period and age at seroconversion were similar in both groups. $36 / 112$ patients died: $21 / 84$ with hemophilia A (25\%) and 15/28 (54\%) with hemophilia B. Mean survival time was 11.7 years. The 10 year cumulative survival was $75.8 \%$. It was lower in hemophilia B (56.2\%) compared to hemophilia A patients $(82.4 \% ; \mathrm{p}=0.002)$. 37 patients $(33 \%)$ developed fullblown AIDS: 26 with hemophilia A (31\%) and 11 with hemophilia B (39\%). Mean AIDS-free survival time was 11.4 years. The 10 -year cumulative AIDS-free survival was $71.2 \%$. It was $74.8 \%$ in hemophilia $A$ and $60.3 \%$ in hemophilia B patients. CD4 counts lower than $200 / \mathrm{cmm}$ occured in 62 patients $(56 \%)$ : 45 with hemophilia $A$ (54\%) and 17 with hemophilia B (63\%). The mean time to CD4 counts lower than 200 was 9.4 years. Mean survival time in older seroconverters ( 35 year old or more) was shorter than in younger (9.5 i's 11.7 years, $\mathrm{p}<0.05$ ). Mean CD4 cell counts at seroconversion were similar in hemophilia $\mathrm{A}$ and $\mathrm{B}$ patients and in different age classes at seroconversion. CD 4 cell counts at seroconversion affected the survival: $90 \%$ seroconverters with CD4 cell counts of $800 / \mathrm{cmm}$ or more were alive at 10 years vs. $60 \%$ of seroconverters with CD4 cell counts lower than $800(p<0.05)$.

\section{Introduction}

The natural history of HIV infection might be influenced by the route of transmission, intensity and frequency of viral exposure, risk behaviors and coinfections. The progression of HIV disease should be characterized in each risk group because this information might affect the decisions concerning the clinical management. Patients with hemophilia constitute a risk group with peculiar features. They have been exposed to HIV for a limited period of time, during which they were infused with contaminated clotting factor concentrates produced from large pools of plasma (Verani et al., 1986). Since virucidal methods were introduced in manufacturing procedures of plasma-derived concentrates and blood-donor screening was adopted in July 1985, only three seroconversions in 1986 and no new cases in the next years were reported in Italian patients with hemophilia (Gringeri et al., 1988). The prevalence of HIV seropositivity in this risk group was $23 \%$ and it was higher in patients with severe hemophilia (39\%) who received larger amount of the concentrate (Gringeri et al., 1988).

The type of concentrate used seems to influence the immunological parameters of these patients. Particularly, the use of high-purity concentrates has been associated to a slower decline of CD4 cell counts (Seremitis et al., 1993). Coinfections with other blood-borne viruses, such as hepatitis $B$ and $C$ viruses and cytomegalovirus, are 
common findings in this population and they could also play a role in the development of AIDS (Webster et al., 1992). In this risk group, complete information on clinical events, therapeutical interventions and laboratory data, including the seroconversion period, is commonly available because hemophilia patients have regularly been followed up at the treatment centers since the diagnosis of hemophilia.

In this retrospective study, HIV disease progression, survival and putative cofactors affecting the outcome were evaluated in the cohort of HIV-infected patients with hemophilia followed-up at our center since seroconversion.

\section{Subjects and methods}

Patients. The study deals with data from records and stored serum samples collected in the period from 1 January 1979 to 30 April 1994. AIDS patients were defined according to the 1987 revised US Centers for Disease Control (CDC) case definition of AIDS (Centers for Disease Control, 1987). Progression to severe immunodeficiency at high risk of developing AIDS was identified by CD4 cell count decline below 200/cmm (Phillips et al., 1992a).

Of overall 512 patients with hemophilia attending our Center since 1975, 329 patients have undergone periodic regular examination every 6-12 months. Of 329 patients, 209 of 271 with hemophilia $A$ and 45 of 58 with hemophilia B presented with a severe coagulation factor defect (plasma factor VIII or IX level lower than $2 \%$ ). HIV infection was detected in 112 of 329 patients (34\%), all with severe hemophilia. Patients with severe hemophilia B had a significantly higher prevalence of HIV seropositivity $(28 / 45,62 \%)$ compared to those with severe hemophilia A $(84 / 209,40 \%$; Chi-square $4.56, \mathrm{p}<0.05)$. Anti-hepatitis $\mathrm{C}$ virus $(\mathrm{HCV})$ antibodies were detected in all HIV-infected patients.

Treatments. All patients had been given the FVIII and FIX concentrates commercially available in Italy (AIMA Derivati, Castelvecchio P., Italy; Baxter Italia, Roma, Italy; Immuno Italia, Pisa, Italy; Sclavo, Siena, Italy). Patients were treated at home or as in-patients or out-patients when bleedings occurred. Patients have received virus-inactivated concentrates since June 1985. Monoclonally-purified concentrate (Hemofil-M, Baxter Italia, Roma, Italy) has been available only for hemophilia A patients and only since July 1993.

Since July 1988 antiretroviral therapy has been given to all patients with HIV-related symptoms and CD4 cell counts lower than 400 cells/cmm or with CD 4 cell counts lower than 250 cells $/ \mathrm{cmm}$ in 2 consecutive occasions irrespective of the presence of symptoms. Zidovudine (Retrovir, Wellcome Foundation, London, UK) was initially given at the dosage of $1 \mathrm{~g}$ a day, then shifted to $0.5 \mathrm{~g}$ a day. More recently, when intolerance or resistance occurred, didanosine (Videx, Bristol-Myers Squibb, 
Evansville, IN, USA) at $400 \mathrm{mg}$ a day or zalcitabine (Hoffmann-La Roche, Basel, Switzerland) al $2.1 \mathrm{mg}$ a day were used, alone or in combination with zidovudine. Pneumocystis carinii pneumonia (PCP) primary prophylaxis with aerosolized pentamidine (Pentacarinat, Roger Bellon, Neuilly-sur-Seine, France) (300 mg a month) has been initiated since 1989 in patients with CD4 cell counts below 200 cells $/ \mathrm{cmm}$, according to the recommendations of Morbidity and Mortality Weekly Report (Morbidity and Mortality Weekly Report, 1989). Subsequently, since 1993, patients have been given cotrimoxazole (Bactrim, Hoffmann-La Roche, Basel, Switzerland) (160/800 mg a day) plus folinic acid, if tolerant. Fluconazole (Diflucan, Roerig Pfizer, New York, NY, USA) has been administered at the dosage of 50-100 $\mathrm{mg}$ a day for candidiasis prophylaxis in patients with CD4 cell counts lower than $100 / \mathrm{cmm}$, since 1990 .

Laboratory Methods. Anti-HIV-l antibody was detected using a commercially available ELISA and confirmed by Western blot on frozen stored serum samples. Lymphocyte subsets were evaluated by flow cytometry (Ortho Spectrum, Ortho Diagnostic, Raritan, NJ, USA) using commercially available monoclonal antibodies. Absolute CD4 lymphocyte counts have been monitored since April 1983.

Statistical Analysis. The date of HIV seroconversion was considered as being the midpoint in time between the last negative and the first positive samples (Kroner ef al., 1994) in 67\% patients. In the remaining patients, in whom the last negative samples were not available, the date of the first possible exposure to HIV was considered as the last negativity. The earliest HIV-positivity found in serum samples of Italian hemophilia patients wats dated December 1979 according to the finding in the U.K. hemophilia cohort (Darby et al., 1989). Therefore, the date of the first possible exposure to HIV was arbitrarily referred to July Ist, 1979 or to the date of the first plasma product infusion if it had been administered after July 1 st, 1979.

CD4 cell counts at HIV seroconversion were considered all those performed within 6 months from the estimated dates of seroconversion. Because T-cell phenotypes have been evaluated only since April 1983, CD4 cell counts at seroconversion of patients who seroconverted earlier than November 1982 were not available.

The Kaplan-Meyer survival analysis (Kaplan et al., 1958) was used to calculate cumulative incidence of the following events: CD4 cell count decline below 200 cells/cmm and 50 cells/cmm, full-blown AIDS and death. Groups were compared with the log rank test. The rate of each event was the number of events divided by the number of patient-years in each considered group. Ninety-five percent confidence intervals (95\% CI) were calculated using standard formulas (Machin et al., 1988). Analysis of variance was used to compare ages and CD4 cell counts at seroconversion in the different groups. 


\section{Results}

Effect of Type of Hemophilia. This hemophilia cohort seroconverted after 1980 and within 1986 (median 1983) at the median age of 18 years (range: $3-56$ ). No difference in seroconversion period and age at seroconversion was found belween patients with hemophilia $A$ and $B$. CD4 cell counts at seroconversion were evaluated in 62 of 112 patients and the mean value was 807 cells/cmm (standard deviation, SD, 335).

Patients with hemophilia $A$ and $B$ showed similar mean CD4 counts at seroconversion: 821 (SD 354 ) and 762 (SD 269) cells/cmm. respectively.

Death occurred in 36 he-mophilia patients of the cohort (32\%); it was AIDS-related in $25(69 \%)$, due to liver failure in $7(19 \%)$, haemorrhages in $2(6 \%)$ and unknown caluses in $2(6 \%)$ of 36 paticnts. Twenty-one deaths (15 AIDS-related) occurred among patients with hemophilia A $(21 / 84.25 \%)$ whereas 15 deaths (10 AIDS-related) occurred in those with hemo-philia B $(15 / 28,54 \%)$. The mortality rate in the cohort was 2.74 deaths per hundred patient-years of observation: the different rates in subjects with hemophilia A and B are shown in Table 1.

The overall mean survival time was 11.7 years (95\% CI 11.2-12.2) (Table 2). The 10-year cumulative survival wats $75.8 \%(95 \% \mathrm{Cl} 67.6-84.0)$ and it was
Fig. 1. Kaplan-Meyer estimation of cumulative probability of surviving by type of hemophilia according to the number of years from seroconversion

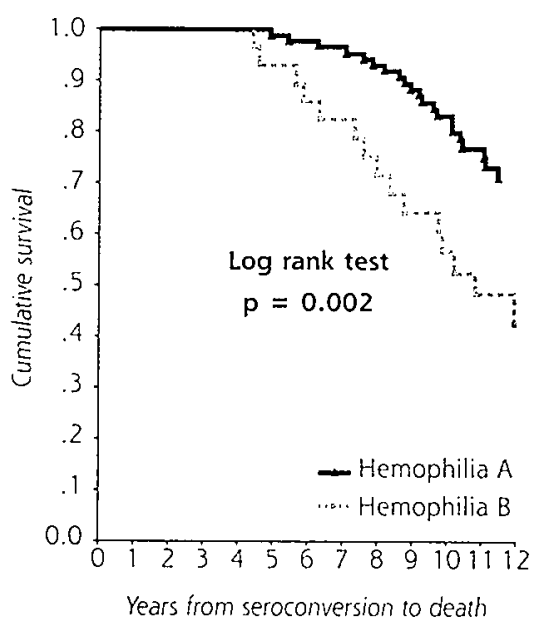


Table 2. Effect of type of hemophilia on survival and progression towards advanced stages of HIV disease

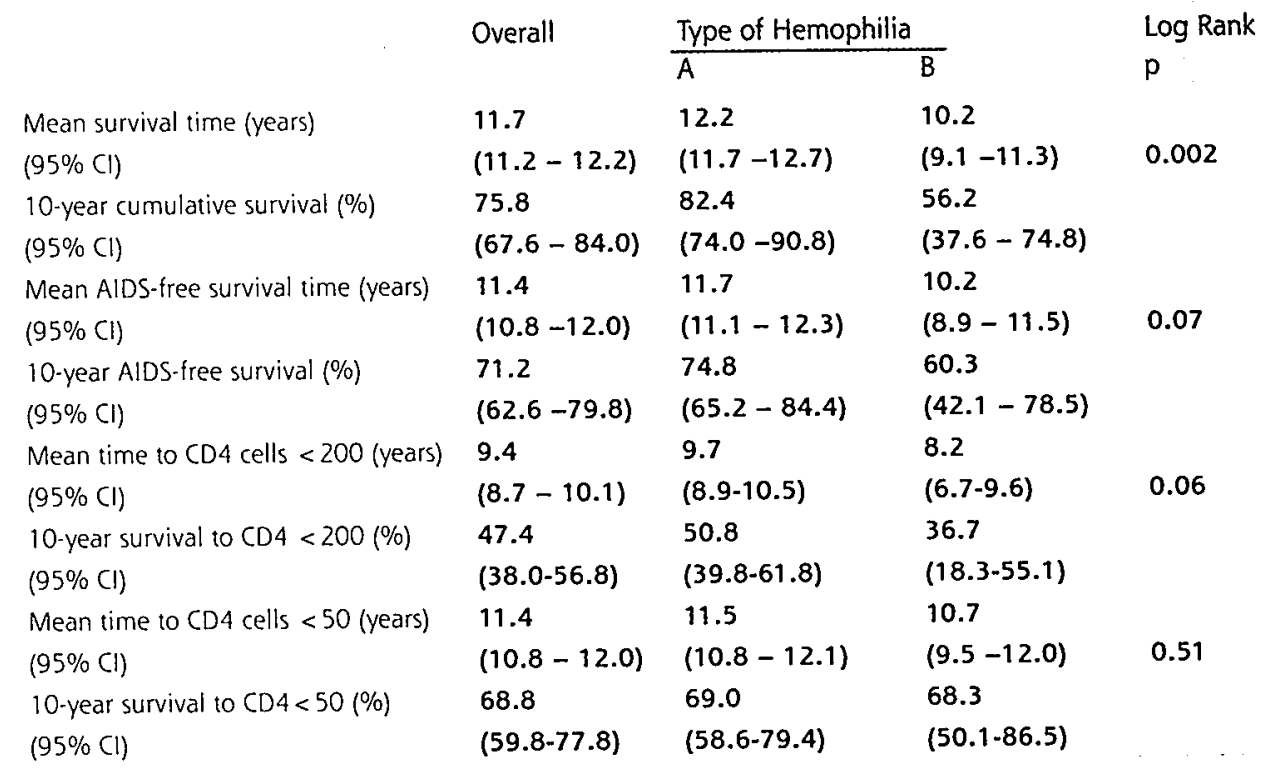

Fig. 2. Kaplan-Meyer estimation of cumulative probability of AIDS-free surviving by type of hemophilia according to the number of years from seroconversion

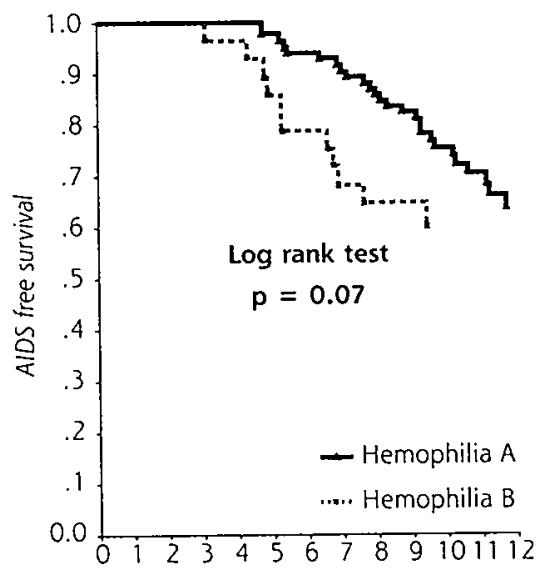

Years from seroconversion to AIDS significantly higher in patients with hemophilia $\mathrm{A}$ than in those with hemophilia $\mathrm{B}: 82.4 \%$ vs. $56.2 \%$ ( $p<0.01$ ) (Table 2 and Fig. 1).

Progression to full-blown AIDS, referred to CDC group IV Cl or D, was observed in 37 patients of the cohort $(33 \%)$ and 25 of them died $(68 \%)$. Among the 84 patients with hemophilia A 26 AIDS cases (31\%) were detected and death occurred in 15 . Eleven patients with hemophilia B $(39 \%)$ developed AIDS and 10 died. The rate of progression to AIDS in the cohort was 2.90 cases per 100 patient-years (Table 1). Mean AIDS-free survival times in the cohort and in patients with hemophilia $A$ and $B$ are reported in table 2. The 10-year cumulative AIDS-free survival in the cohort was $71.2 \%(95 \% \mathrm{CI} 62.6-79.8)$ and differences were found between patients with hemophilia $A$ and $B(p=0.07)$ (Table 2 and Fig. 2). 
Table 3. Effect of age at seroconversion on survival and progression towards advanced stages of HIV disease

\begin{tabular}{|c|c|c|c|c|}
\hline & \multicolumn{3}{|c|}{ Age at Seroconversion } & \multirow{2}{*}{$\begin{array}{l}\log \text { Rank } \\
p\end{array}$} \\
\hline & $<12$ & $13-34$ & $>35$ & \\
\hline Mean survival time (years) & 11.8 & 11.7 & 9.5 & \\
\hline$(95 \% \mathrm{CI})$ & $(10.8-12.8)$ & $(11.2-12.2)$ & $(8.0-11.0)$ & 0.016 \\
\hline 10-year cumulative survival (\%) & 76.1 & 80.4 & 50.0 & \\
\hline$(95 \%$ Cl) & $(60.6-91.6)$ & $(70.8-90.0)$ & $(21.8-78.2)$ & \\
\hline Mean AIDS-free survival time (years) & 11.2 & 11.2 & 10.7 & \\
\hline$(95 \%$ (I) & $(9.9-12.4)$ & $(10.6-11.8)$ & $(8.9-12.6)$ & 0.81 \\
\hline 10-year AIDS-free survival (\%) & 66.7 & 72.9 & 71.4 & \\
\hline$(95 \%$ Cl) & $(49.8-83.6)$ & $(62.1-83.7)$ & $(43.2-99.6)$ & \\
\hline Mean time to CD4 cells $<200$ (years) & 9.2 & 9.4 & 8.6 & \\
\hline$(95 \% \mathrm{CI})$ & $(7.8-10.4)$ & $(8.5-10.2)$ & $(6.4-10.8)$ & 0.86 \\
\hline 10-year survival to $C D 4<200(\%)$ & 47.6 & 50.8 & 43.6 & \\
\hline$(95 \%(\mathrm{Cl})$ & $(38.0-57.2)$ & $(38.8-62.8)$ & $(12.8-74.0)$ & \\
\hline Mean time to CD4 cells $<50$ (years) & 11.2 & 11.1 & 11.1 & \\
\hline$(95 \% \mathrm{CI})$ & $(10.1-12.4)$ & $(10.4-11.7)$ & $(9.6-12.5)$ & 0.89 \\
\hline 10-year survival to CD4 $<50(\%)$ & 63.7 & 71.1 & 68.2 & \\
\hline$(95 \% \mathrm{Cl})$ & $(45.7-81.7)$ & $(60.1-82.1)$ & $(38.0-98.4)$ & \\
\hline
\end{tabular}

CD4 cell count decline below $200 / \mathrm{cmm}$ occurred in 62 patients (56\%): 45 among subjects with hemophilia $A(54 \%)$ and 17 among those with hemophilia $B$ $(63 \%)$. The rates of progression to CD4 cell count lower than $200 / \mathrm{cmm}$ in the cohort and in the 2 groups of hemophilia patients are shown in Table 1. The mean time from seroconversion to development of the CD4 cell decline was 9.4 years $(95 \% \mathrm{CI} 8.7$ 10.1 ) and 10-year cumulative survival before reaching this immunodeficiency condition was $47.4 \%$ (95\% CI 38.0-56.8); the different findings for type of hemophilia are reported in Table 2.

Drastic CD4 cell depletion (CD4 cell count lower than $50 / \mathrm{cmm}$ ) was observed in 37 hemophilia patients (34\%), 28 of those with hemophilia A (34\%) and 9 with hemophilia B (33\%) (Table 1). The mean time for developing CD4 cell depletion was 11.4

Fig. 3. Kaplan-Meyer estimation of cumulative probability of surviving by age at seroconversion according to the number of years from seroconversion

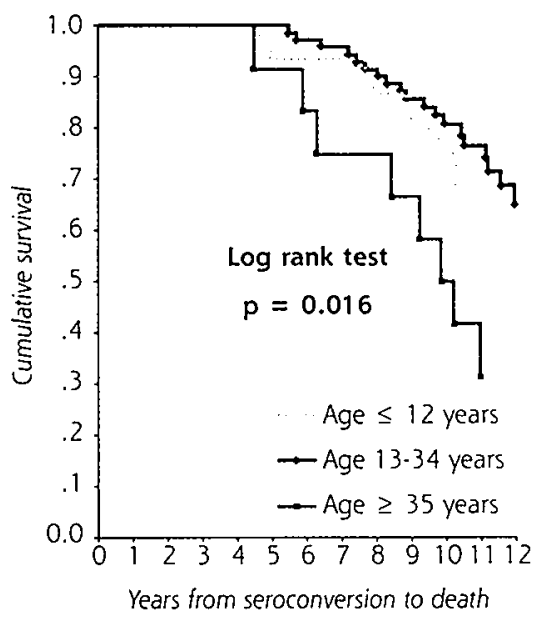


Table 4. Effect of CD4 cell counts at seroconversion on survival and progression towards advanced stages of HIV disease

\begin{tabular}{|c|c|c|c|}
\hline & CD4 Cell Cou & it Seroconversion & Log Rank \\
\hline & $<800 / \mathrm{cmm}$ & $>800 / \mathrm{cmm53}$ & $p$ \\
\hline Mean survival time (years) & 10.5 & 11.7 & \\
\hline$(95 \%$ Cl) & $(9.6-11.4)$ & $(11.0-12.3)$ & 0.03 \\
\hline 10-year cumulative survival $(\%)$ & 60.0 & 90.2 & \\
\hline$(95 \% \mathrm{Cl})$ & $(41.2-78.8)$ & $(79.6-100.0)$ & \\
\hline Mean AIDS-free survival time (years) & 10.6 & 11.2 & \\
\hline$(95 \%(1)$ & $(9.6-11.7)$ & $(10.3-12.0)$ & 0.46 \\
\hline 10-year AIDS-free survival (\%) & 72.3 & 72.7 & \\
\hline$(95 \% \mathrm{CI})$ & $(55.8-88.8)$ & $(56.2-89.2)$ & \\
\hline Mean time to CD4 cells < 200 (years) & 8.2 & 9.6 & \\
\hline$(95 \% \mathrm{Cl})$ & $(7.0-9.4)$ & $(8.4-10.7)$ & 0.11 \\
\hline 10-year survival to CD $4<200(\%)$ & 35.0 & 53.00 & \\
\hline$(95 \%(1)$ & $(17.4-52.6)$ & $(34.8-71.2)$ & \\
\hline Mean time to CD4 cells $<50$ (years) & 10.7 & 11.6 & \\
\hline$(95 \%$ Cl) & $(9.8-11.7)$ & $(10.9-12.2)$ & 0.26 \\
\hline 10-year survival to CD4 $<50(\%)$ & 65.9 & 79.3 & \\
\hline$(95 \% \mathrm{Cl})$ & $(46.1 .85 .7)$ & $(64.4-94.2)$ & \\
\hline
\end{tabular}

years $(95 \% \mathrm{CI}$ 10.8-11.9), 10-year cumulative survival to CD4 cell depletion was $68.8 \%$ (95\% CI 59.8-77.8) and no statistically significant difference was recorded between patients with hemophilia $A$ and $B$ (Table 2).

Effect of Age at Seroconversion. To evaluate the effect of age at se-roconversion on survival, mean survival time and 10-year cumulative survival by age classes at seroconversion were compared (Table 3 and Fig. 3 ). Survival of patients infected at the age of 35 years or more was significantly shorter than that shown by younger seroconverters $(p<0.05)$. Older and younger seroconverters similarly progressed to AIDS. severe immunodeficency (CD4 cell counts below 200/cmm) and extreme CD4 cell depletion (CD4 cell counts below $50 / \mathrm{cmm}$ ) (Table 3 ).

Effect of CD4 Cell Count at Seroconversion. Survival of the cohort was affected by CD4 cell counts at seroconversion: ten years after seroconversion $90 \%$ of he-mophilia patients with CD4 counts at seroconversion of $800 / \mathrm{cmm}$ or more were alive compared to $60 \%$ of patients with CD4 counts at seroconversion lower than $800 / \mathrm{cmm}(p<0.05)$ (Fig. 4 and Table 4). No statistically significant difference 
in progression to AIDS, severe im-munodeficiency and CD4 cell depletion was observed between the two groups of patients with different CD4 cell counts at seroconversion (Table 4).

Mean CD4 cell counts at seroconversion were similar in the seroconverters of different age classes: 794 (SD 351) cells/cmm in the patients aged 12 years or younger, 815 (SD 333) cells/cmm in those aged between 13 and 34 years, and 803 (SD 358) in those who were at least 35 years old at seroconversion.

\section{Discussion}

Cumulative survival after seroconversion in our cohort was longer than in other series of hemophilia patients: a survival of $48 \%(95 \% \mathrm{CI} 31-65)$ after 12 years was reported in 111 British patients with hemophilia (Phillips et al., 1992b) compared to $63 \%$ (95\% CI 52-73) in our patients. This discrepancy can partially be explained by differences in the patient populations, among which age at seroconversion may play a role. In fact, British patients were older at seroconversion than our patients (median age 25 is 18 years). Older seroconverters (age $\geq 35$ years) in the lalian cohort showed a shorter survival compared to younger patients. Others authors (Ehmann ct al.. 1994) reported that age higher than 18 years at seroconversion is a significant factor predicting shorter survival among HIV-infected hemophilia patients. Several studies evaluated the effect of age at seroconversion on progression to AIDS and showed a strong association between older age and faster disease progression (Darby et al., 1989; Eyster et al., 1987; Goedert et al., 1989; Sabin et al., 1993; Schinaia et al. 1991), supporting the hypothesis that a higher storage of CD4 precursor cells in younger people could account for a longer maintenance of the asymptomatic condition (Ragni et al., 1989). On the contrary, our data showed that age at seroconversion influenced only survival, whilst it did not have any effect on progression, either in terms of development of full-blown AIDS or in terms of CD4 cell depletion. On the other hand, this study showed that CD4 cell counts at seroconversion were similar in different age classes, they did not in-fluence the occurrence of symptomatic disease and CD4 cell decline, whereas higher $\mathrm{CD} 4$ cell counts in seroconverters were associated with longer survival. To our knowledge, this is the first study evaluating the impact of CD4 cell counts at seroconversion on the natural history of HIV disease.

Rate of progression to AIDS at 7-9 years from seroconversion in our patients was similar to that reported in larger multicentric studies in the U.K. (Darby et al.. 1989) and the USA (Goedert et al., 1989) as well as in the italian multicentric study (Schinaia et al., 1991). Comparing our data to those of the British cohort (Sabin et al., 1993) followed up for a longer period of time, cumulative progression rate at 12 years seems to be lower in our patients (37.5\% vis. $45.0 \%$ ). 
AIDS-free survival and time to CD4 cell counts lower than 50 cells/cmm are virtually identical in our cohort (11.4 years), whereas a CD4 cell decline below $200 / \mathrm{cmm}$ preceded the occurrence of AIDS of about 2 years.

The Italian multicentric studies showed a higher prevalence of HIV infection in patients with hemophilia B compared to those with hemophilia A (Gringeri et al., 1988) and a strong association between faster progression to AIDS and hemophilia B (Schinaia et al., 1994). In our cohort, HIV infection was more prevalent in patients with hemopbilia $B$, but only survival rate was significantly affected by the type of hemophilia, whilst AIDS-free survival and time to development of CD4 cell counts below $200 / \mathrm{cmm}$ appear less likely to be influenced. Our patients with hemophilia $\mathrm{A}$ and $B$ were exposed to HIV-infected concentrates derived from plasma obtained from paid American plasmapheresis donors between 1980 and 1986, at similar ages and at the same period of time. CD4 cell counts at seroconversion were also similar in both groups of patients.

The main distinctive feature between patients with hemophilia A and B is the type of clotting factor concentrate used. Viral load and/or HIV variant strains in the infected batches of factor VIII and factor IX concentrates, before the introduction of virucidal methods, and, afterwards, as well as the presence of proteic contaminants may represent possibe biological factors for explaining different findings in the two groups of patients with hemophilia. On the other hand, high purity, monoclonally-purified concentrates, thought to be effective in slowing down CD4 cell decline (Seremitis et al., 1993), which were available in Italy only for factor VIII recipients, have been licenced only since July 1993 and could hardly affect the natural history of HIV infection in these patients. Follow-up of our cohort for a longer time could reconcile the different data from our study and the Italian multicentric one. Opportunistic infection prophylaxis, more extensively used over the last years, and the progressive loss of efficacy of antiretroviral treatments oyer time might have delayed occurrence of symptomatic disease in our cohort, whereas survival time does not seem to be related to therapy. In conclusion, the type of hemophilia and age at seroconversion were found to be strongly associated with survival of HIV-infected hemophilia patients. The effect of these factors on survival were not related to corresponding effects on progression to full-blown AIDS or severe CD4 cell depletion. These outcomes are probably more influenced by anti-retroviral therapy and prophylaxis for opportunistic infections. Only the specific type of hemophilia seems to have some influence on progression to AIDS, as previously reported (Schinaia et al., 1994). CD4 cell counts at seroconversion were identified for the first time with a significant factor predicting survival in patients with hemophilla, whereas it was not related to progression to advanced stages of HIV disease. 


\section{References}

1. Centers for Disease Control, Revision of the CDC surveillance case definition for acquired immunodeficiency syndrome. Morlid. Mortal. neek. Rep. 1987, 30: 1S-15.5.

2. Darby S, Rizza CR, Doll R, Spooner RJD, Stratton, IM and Thakrar B: Incidence of AIDS and excess of mortality associated with HIV in haemophiliacs in the United Kingdom: report on behalf of the directors of the haemophilia centres in the United Kingdom. Br: med J. 1989. 298:106t-1068.

3. Ehmann WC, Eyster ME, Wilson SE. Andes WA and Goedert JJ. (For the Multicenter Hemophilia Cohort Study): Relationship of CD4 lymphocyte counts to survival in a cohort of hemophiliacs infected with HIV.I. acc.imm. Defic: Sindr: 1994, 7:1095-1098.

4. Eyster ME, Gail MH, Balliurd JO, Al-Mondhiry $\mathrm{H}$ and Goedert JJ: Natural history of human immuno-deficiency virus infection in haemophiliacs: effects of $\Upsilon$ subsets, platelet counts and age. Anm. intrn. Med. 1987, 107: 1-6.

5. Goedert JJ, Kessler CM, Aledort LM. Biggar RJ, Andes WA, White GC. Drummond JE, Vaidya K. Maun DL, Eyster ME, Ragni MV. Lederman MM. Cohen AR. Bray GL. Rosenberg PS. Friedman RM, Hilgartner MW, Blattner WA. Kroner B and Gail MH: A prospective study of human immuno-deficiency virus type 1 infection and the development of AIDS in subjects with hemophilia. N. Engl.J. Med. 1989. 321: $1141-1148$.

6. Gringeri A. Mannucci PM and the MedicalScientific Committee of the Fondazione dell'Emofilia: National survey of HIV infection in Italian hemophiliacs: 1983-1987. Ric. clin. Lab. 1988, 18: 275-280.

7. Kaplan EL and Meier P: Nonparametric estimation from incomplete observations. J. am Stat. Assoc. 1958. 53: 457-481.

8. Kraner BL. Rosenberg PS. Aledort LM. Alvord WG and Goeden JJ (For the Multicenter
Hemophilia Cohort Study): HIV-l infection incidence among persons with hemophilia in the United States and Western Europe, 1978-1990. J. ucq.imm. Defic. Sỵdr: 1994. 7: 279-286.

9. Machin D and Gardner MJ: Calculating confidence intervals for survival time analyses. $B r$. med.J. 1988.296: 1.369-1.371.

10. Morbidity and Mortality Weekly Report, Guidelines for prophylaxis against Pneumocystis carinii pneumonia for patients infected with human immunodeficiency virus. Morbid. Morral week. Rep. 1989. 38: 1-9.

11. Phillips AN, Elford J, Sabin C. Bofill M, Janossy $G$ and Lee $C A$ : Immunodeficiency and the risk of death in HIV infection. JAMA $1992 \mathrm{~b}$. 268: 2602-2660.

12. Phillips AN. Lee CA. Elford J. Janossy G and Kernoff PBA: The cumulative risk of AIDS as the CD4 lymphocyte count declines. J. acq. $\mathrm{imm}$. Defic. Sindr: 1992a.5: 148-152.

13. Ragni MV, Kingsley LA, Justice AC. Feinstein $A R$ and Wells CK: Importance of age in prognostic staging system for AIDS (letter). N. Engl. I. Med. 1989, 321: 1408-1409.

14. Sabin C. Phillips A. Elford J. Griffiths P. Janossay $\mathrm{G}$ and Lec $\mathrm{C}$ : The progression of HIV disease in a haemophilic cohort followed for 12 years. Br.l. Hacmatol. 1993.83:330-333.

15. Schinaia N, Ghirardini A, Chiarotui F. Gringeri A. Mannucci PM and the Italian Group:

Progression to AIDS among Italian HIV-seropositive haemophiliacs. AIDS 1991.5:385-391. 16. Schinaia N. Ghirardini AMG. Mazzucconi MG. Tagariello G. Morfini M. Chiarotti $F$ and the G.I.C.C: Clinjcal factors associated with progression to AIDS in the Italian cohort of HIVpositive bemophiliacs. Thromb. Haemost. 1994. 72: $33-38$.

17. Serenitis S.. Aledort LM. Bergman GE. Bona R. Bray G. Brettler D. Eyster ME. Kessler C. Lau TS. Lusher J and Rickles F: Three-year randomized study of high-purity or interme- 
diate-purity factor VIII concentrates in symptom-free HIV-seropositive haemophiliacs: effects on immune status. Lancet 1993. 342: 700-703.

18. Verani P, Mariant G, Mannucci PM. De Rossi G, Nicoletti L. Titti F, Falcione E, Pasqualcti D. Ammassari M, Gringeri A, Mandelli F and Rossi GB: Prevalence of HTLV-III/LAV antibodies in Italian asympto- matic hemophiliacs given commercial concentrates of factors VIII and IX.J. med Virol 1986, 19: 143-149.

19. Webster A, Phillips AN, Lee CA, Janossy G Kernoff $\mathrm{PB}$ and Griffiths PD: Cytomegalovirus (CMV) infection, CD4+ lymphocytes counts and the development of AIDS in HIV-I-infected haemophiliac patients. Clin. exp. Immunol 1992, 88: 6-9 


\title{
Hemophilia and nonprogressing human immunodeficiency virus type 1 infection
}

\author{
E. Vicenzi', P. Bagnarelli², E. Santagostino', S. Ghezzi', \\ M. Alfano', M.S. Sinnone', G. Fabio', L. Turchetto, \\ G. Moretti", A. Lazzarin', A. Mantovani', P.M. Mannucci ${ }^{3}$, \\ M. Clementi ${ }^{7}$ A. Gringeri ${ }^{3}$, G. Poli ${ }^{1}$ \\ 'AIDS Immunopathogenesis Unit, DIBIT, Department of Infectious Diseases, and \\ Laboratory of Analytical Chemistry, San Raffaele Scientific Institute, Milan; \\ 2Institute of Microbiology, University of Ancona, Ancona; \\ 3.'A. Bianchi Bonomi" Hemophilia and Thrombosis Center, Maggiore Hospital, Milan; \\ +/nstiture of Clinical Immumology and Infectious Diseases, University of Milan, Milan; \\ s Deparment of Immunology and Cell Biology, "Mario Negri" \\ Institute for Pharmacological Research, Milan; \\ 'Instiute of Pathology, University of Brescia, Brescia; \\ ${ }^{7}$ Department of Biomedical Sciences, University of Trieste, Trieste, Italy.
}

Blood 89: 191-200, 1997

Grant support: This study was supported by a grant from the 1995 AIDS Project of the Istituto Superiore di Sanita, Rome, Italy 


\section{Abstract}

Seven of 112 hemophiliacs infected with human immunodeficiency virus type-1 (HIV-1) before 1986 through contaminated plasma products are currently healthy, with CD4 T-cell counts above 500 cells/ $\mu \mathrm{L}$, and have never received antiretroviral therapy (long-term nonprogressors [LTNPs]). Seven age and sex-matched hemophiliacs infected in the same period but who have progressive HIV disease (progressors) and one additional slow-progressing individual were also studied. One hundred-fold, 20-fold, and 10fold lower levels of full-length HIV RNA in plasma, peripheral blood mononuclear cells (PBMCs), and proviral DNA in PBMCs, respectively, were found in LTNPs compared with progressors. Plasma and cell-associated HIV RNA and proviral DNA were lower in LTNPs who tested negative for viral isolation from PBMCs or who were positive only after removal of CD8+ cells. No substantial differences were observed in the in vitro production of chemokines including RANTES, MIP-1 $\alpha$, MIP-1 $\beta$, MCP-1, and interleukin- 8 (IL-8) in supernatants of activated PBMCs or CD8-depleted PBMCs of LTNPs, even when HIV isolation was simultaneously accomplished exclusively after removal of CD8+ cells. Low levels of HIV load and replication in peripheral blood are the strongest correlates of nonprogression in this small number of infected hemophiliacs.

\section{Introduction}

Human Immunodeficiency virus type-1 (HIV-1) infection leads to a defined pattern of disease progression in most infected individuals. After primary infection, manifesting in some individuals as an acute clinical syndrome, a prolonged period of clinical latency and then clinically overt disease characterized by emergence of opportunistic infections and tumors occurs with an average time of 9 to 10 years. ${ }^{1}$ During primary infection, several infected CD4+ $T$ cells and a large amount of plasma-associated virus are found in the blood stream. ${ }^{2 \cdot 5}$ Then, the amount of circulating virus and viral expression in peripheral blood mononuclear cells (PBMCs) rapidly decline as the humoral and cellular immune responses increase ${ }^{5.7}$ marking the beginning of the clinically latent period. The onset of disease coincides with a steeper loss of circulating CD4+ $T$ cells and an increase in cellassociated HIV expression and plasma viremia. I However, in this scenario, a minority of infected individuals with nonprogressive infection and belonging to all risk categories ${ }^{x .9}$ have emerged and have been variably defined as long-term nonprogressors (LTNPS), long-term survivors, or long-term asymptomatics. LTNPs are characterized by stable or even increasing CD4+ T-cell counts above 500 cells/ $\mu \mathrm{L}$ blood and by strong immune responses, as shown by a high frequency of cytotoxic $\mathrm{T}$ lymphocytes against HIV proteins and presence of anti-HIV neutralizing antibodies. ${ }^{\text {10.12 }}$ Although substantial agreement exists in describing lower levels of viral replication in LTNPs, remarkable differences in the quantitative levels of plasma-associated HIV RNA have been reported by different 
investigators, suggesting that LTNPs may indeed represent a heterogeneous group of individuals. A role of human MHC genes in HIV disease progression is highly debated and supported by some studies. ${ }^{3.14}$ The hypothesis that some LTNPs may possess peculiar immune responses capable of selecting strains of HIV with attenuated pathogenicity or that they had been infected by some of these strains has been suggested in the case of a single LTNP hemophiliac ${ }^{15}$ and a cohort of a blood donor and six recipients carrying a predominant species of HIV-1 with large deletions in the nef gene. ${ }^{16}$ These findings reinforce the hypothesis of a crucial role of nef in in vivo viral replication and progression of HIV disease, as previously described in macaques infected with simian immunodeficiency viruses carrying similar deletions. ${ }^{17}$

Hemophiliacs represent a peculiar population among risk groups, and provide a unique opportunity to investigate progression to AIDS. In fact, they have been exposed to HIV for the limited period during which they were infused with contaminated clotting factor concentrates derived from large pools of plasma. Most hemophiliacs in Italy could have been infected until virus-inactivation methods were introduced in the purification of concentrates in July 1985. ${ }^{1 \times .1 \%}$ The prevalence of HIV seropositivity in Italian hemophiliacs is $23 \%, 19$ additional HIV seroconversions due to transfusions are unlikely to occur, providing a stable cohort. The majority of these patients are evaluated on a frequent and regular basis by the medical staff of a limited number of centers specialized in the treatment of hemophilia. For these reasons, complete information on clinical events, therapeutic interventions, and laboratory parameters are more easily available and study drop-outs are less common than in other risk categories. Furthermore, hemophiliacs are less exposed to sexually transmitted diseases compared with other populations at risk for HIV. Their seroconversion dates are precisely documented because repeated serum samples were collected on a regular schedule before and throughout the period of exposure to HIV infection.

We have examined the virologic state of seven individuals with characteristics of LTNPS selected from a well-characterized cohort of HIV-infected hemophiliacs. These individuals have been matched for sex, age, and duration of infection with seven hemophiliacs with CD4+ T-cell counts less than 200 cells/ $\mu \mathrm{L}$ blood and in different stages of disease progression. An additional individual with characteristics of a long-term progressor (LTP), ie, with CD4+ cell counts that had been stable for 12 years but who unequivocally showed signs of disease progression at study entry, was also studied. The infectious capacity of the HIV was measured by viral isolation from plasma, PBMCs, or CD8-depleted PBMCs. Levels of HIV replication in vivo were defined in terms of both plasma and cellassociated viral RNA. The HIV proviral DNA load in PBMCs was quantified in both progressors and LTNPS. Finally, production of chemokines, some of which have been recently shown to suppress HIV replication, ${ }^{31.2 \mathrm{x}}$ during HIV isolation has been determined in some LTNPs. 
Table 1. Hemophiliac LTNPs and progressors

\begin{tabular}{|c|c|c|c|c|c|c|c|c|c|}
\hline Patient & Age $(\mathrm{Vr}) \mathrm{J}$ & Hemophilia & $1 \mathrm{st}$ & $\mathrm{CD} 4^{+}$ & $\mathrm{CD}^{+}+$ & $C D C$ & Start Anti-HIV & \multicolumn{2}{|l|}{ HLA Type } \\
\hline No. & Sex & Type & $\begin{array}{l}\text { Anti-HIV+ } \\
(y r)\end{array}$ & $\begin{array}{l}\text { Count } \\
(\text { Cells } / \mu \mathrm{L})^{*}\end{array}$ & $\begin{array}{l}\text { Count } \\
(\text { Cells } / \mu L)^{*}\end{array}$ & Group & Therapy (yr) & Class I & Class II \\
\hline LTNPS & & & & & & & & & \\
\hline 1 & $20 / M$ & B & 1984 & 1.135 & 1,841 & & & $\begin{array}{l}\mathrm{A} 11,30 ; B 14,38 \\
\text { Cw6; Bw 4, 6DQ1 }\end{array}$ & DR 10 \\
\hline 2 & $33 / \mathrm{M}$ & A & 1983 & 600 & 1.607 & & & $\begin{array}{l}A 2,32 ; B 35,51 \\
C w 3,4 ; 8 w 4,6\end{array}$ & $\begin{array}{l}\text { DR11, 14,52 } \\
\text { DQ } 1.7\end{array}$ \\
\hline 3 & $29 / \mathrm{M}$ & A & 1984 & 1.047 & 1,806 & & & $\begin{array}{l}\mathrm{A} 3,11 ; 813,35 \\
\text { Cw6; Bw4, 6DQ1, } 2\end{array}$ & DR $1,7,53$ \\
\hline 4 & $18 / F$ & B carrier & 1984 & 905 & 988 & & & $\begin{array}{l}\mathrm{A} 1 ; \mathrm{B} 51,57 \mathrm{DR} 4,52 \\
\mathrm{C} w 1,6 ; \mathrm{B} w \text { 4DQ1, }\end{array}$ & 2.53 \\
\hline 5 & $46 / \mathrm{M}$ & B & 1985 & 619 & 1,164 & & & $\begin{array}{l}\mathrm{A} 2 ; \mathrm{B} 50,57 \mathrm{DR} 1,3, \\
\text { Cw6; Bw4,6DQ1, } 2\end{array}$ & \\
\hline 6 & $18 / \mathrm{M}$ & A & 1985 & 630 & 680 & & & $\begin{array}{l}\mathrm{A} 3,33 ; \mathrm{B} 13,14 \\
\text { Cw6; Bw4, 6DQ1, } 2\end{array}$ & DR1, 7, 53 \\
\hline 7 & $26 / \mathrm{M}$ & A & 1983 & 669 & 1.155 & & & $\begin{array}{l}\mathrm{A} 3,11 ; \mathrm{B} 44,51 \\
\mathrm{Bw4} \quad \mathrm{DQ2}\end{array}$ & DR7 \\
\hline Progres: & sors & & & & & & & & \\
\hline 8 & $42 / \mathrm{M}$ & $A$ & 1984 & $445^{\wedge}$ & 1.886 & $A 2$ & NA & $\begin{array}{l}A 2,26 ; B 35,57 \\
C w 4 ; B w 4,6 D Q 1,7\end{array}$ & DR2, 11, 52 \\
\hline 9 & $36 / M$ & A & 1984 & 162 & 1.002 & $\mathrm{C} 2$ & 1991 & $\begin{array}{l}A 25,28 ; B 18,35 \\
C w 3,4: B w 4,6\end{array}$ & $\begin{array}{l}\text { DR4, } 15,53 \\
\text { DQ } 1,3\end{array}$ \\
\hline 10 & $27 / M$ & A & 1985 & 105 & 603 & B2 & 1993 & $\begin{array}{l}A 1,2 ; B 35,49 \\
C w 4,7 ; B w 4,6\end{array}$ & $\begin{array}{l}\text { DR1, } 7,53 \\
\text { DQ1, } 2\end{array}$ \\
\hline 11 & $22 / \mathrm{M}$ & A & 1983 & 139 & 1,201 & $\mathrm{C} 2$ & 1992 & $\begin{array}{l}A 2,26 ; B 35,51 \\
C w 2,4 ; B w 4,6\end{array}$ & $\begin{array}{l}\text { DR } 1,13,52 \\
\text { DQ5 }\end{array}$ \\
\hline 12 & $49 / M$ & A & 1984 & 122 & 1,314 & $A 2$ & 1992 & $\begin{array}{l}A 28,34: B 8,14 \\
C w 7 ; B w 6 D Q 1,2\end{array}$ & DR 1.3 .52 \\
\hline 13 & $35 / \mathrm{M}$ & A & 1983 & 56 & 479 & B2 & 1993 & $\begin{array}{l}A 24,29 ; B 7,44 \\
C w 6,7: B w 4,6\end{array}$ & $\begin{array}{l}D R 3,7,52,53 \\
D Q 1,2\end{array}$ \\
\hline 14 & $33 / \mathrm{M}$ & B & 1983 & 69 & 712 & $A 2$ & NA & $\begin{array}{l}A 24,32 ; B 62 D R 12,5 \\
C w 1,7 ; B w 4,6\end{array}$ & 52 \\
\hline 15 & $35 / \mathrm{M}$ & $B$ & 1983 & 31 & 459 & 82 & NA & $\begin{array}{l}\text { A3, 33; B14DR1, 52 } \\
\text { Cw7; Bw6DQ1, } 3\end{array}$ & \\
\hline
\end{tabular}

Abbreviations: NA, not applicable.

* At study entry.

- CD4 cell counts of patient no. 8 decreased to 350/ $\mu \mathrm{L}$ shortly after beginning the study 


\section{Subjects and methods}

HIV-Infected Individuals. LTNPS. HIV seroconversion was retrospectively analyzed on stored serum samples of 329 hemophiliacs reporting regularly to the A. Bianchi Bonomi Hemophilia and Thrombosis Center in Milan.

Seroconversion occurred between 1980 and 1986 in 112 individuals (34\%) who were affected by severe hemophilia, ${ }^{, "}$ seven of whom $(6.2 \%)$ fit the definition of LTNPs according to the following criteria: infection lasting for at least 10 years, absence of HIV-associated symptoms, CD4+ T-cell counts of at least 500 cells $/ \mu \mathrm{L}$ blood (Fig lA), and no antiretroviral therapy. The main characteristics of these LTNPs are shown in Table 1. Four men are affected by severe hemophilia $A$ (patients no. 2, 3,6, and 7) and two by hemophilia B (no. 1 and 5); one woman (no. 4) is a hemophilia B carrier. The median age of these subjects is 26 years (range, 18 to 46 ), and their HIV seropositivity was first detected between 1983 and 1985. All LTNPs had chronic hepatitis C virus (HCV) infection. From seroconversion to study entry, the seven patients had always been asymptomatic with undetectable HIV-1 p24 Gag antigen in the plasma as determined by an immunoenzymatic commercial method (Abbott Laboratories, North Chicago, IL). Their CD4+ T-cell counts have been stable for at least 10 years of observation (Fig_1A), and the mean CD4+ and CD8+ lymphocyte counts at study entry were 801 (range, 600 to 1,135) and 1,320 (range, 680 to 1,841 ) cells per microliter of blood, respectively (Table 1). All LTNPs are in a stable healthy condition with no loss of CD4+ T lymphocytes thus far.

Progressors. Among patients attending the A. Bianchi Bonomi Center, seven hemophiliacs who were comparable to the LTNPs for age (median, 35 years; range, 22 to 49), sex, and duration of HIV infection but who showed signs of disease progression were studied in parallel. Their CD4+ T-cell counts have been persistently less than 200 cells/ $\mu \mathrm{L}$ blood. One additional LTP (patient no. 8) had characteristics of LTNPs up to a few months before the beginning of the study. Unfortunately, he showed a consistent loss of CD4+ T cells in subsequent determinations at 1 -month intervals (from 445 cells/ $\mu \mathrm{L}$ at study entry to 333 and 350 cells/ $\mu \mathrm{L} ;$ Fig 1 ), although with undetectable plasma p24 antigen (Ag) and no clinical signs of HIV-related disease. For these reasons, patient no. 8 was added separately to the control group. Table 1 shows the characteristics of these eight individuals with variably progressing HIV disease. The first HIV seropositivity was dated between 1983 and 1985 . All progressors, like LTNPs, are affected by chronic HCV infection. At the beginning of the study, the controls had mean CD4+ T-cell counts of 141 (range, 31 to 445) and CD8+ T-cell counts of 957 (range, 459 to 1,886) cells per microliter of blood, respectively. Values less than $200 \mathrm{CD} 4+$ cells/ $\mu \mathrm{L}$ were constantly observed during the past 1 to 5 years (median, 2), with the exception of patient no. 8 (Fig 1B). Plasma levels of p24 Ag have been undetectable in all patients, with the exception of patient no. 11 (maximal peak, 62 $\mathrm{pg} / \mathrm{mL}$ ). The year of seroconversion in both LTNPs and controls was retrospectively deter- 
Fig. 1. Circulating levels of CD4 $+T$ lymphocytes in hemophilic LNTPs (A). Two peculiar infected hemophiliacs have been included (B). Patient no. 9 showed relatively stable level of CD4+T cells over the last 4 years, whereas patient no. 8 has demonstrated a LTNP-like profile up to 11 years since infection, when both the CD4 count and clinical condition have begun to deteriorate (long-term progressor).

A
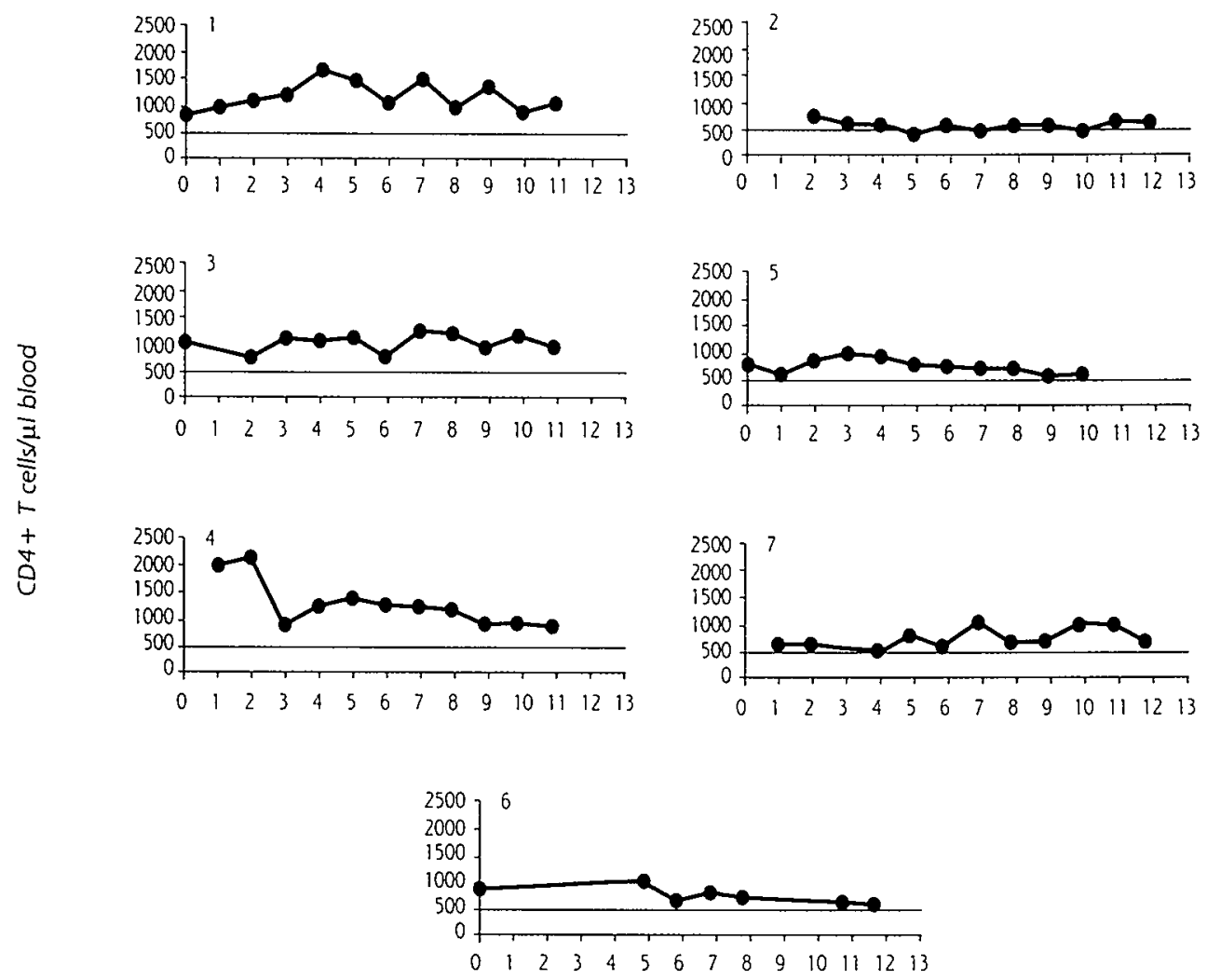

B
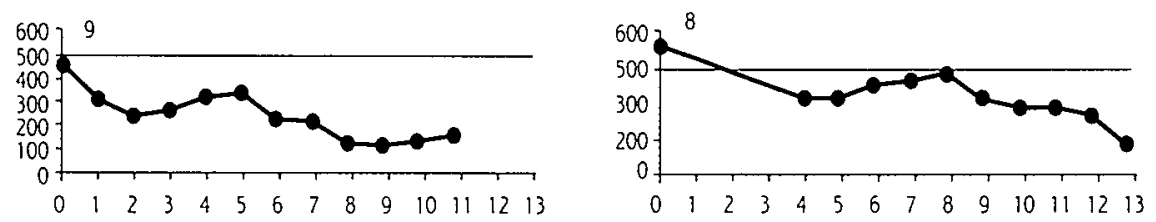

Years since seroconversion 
mined by Westem blot analysis of frozen sera collected beween 1980 and 1985. The seroconversion time was determined as the midpoint between the last negative and first positive Western blot determination. Two progressors had developed AIDS (C2 in the classilication of the Centers for Discase Control"1) between 1993 and 1995.

Extrapumonary Mycohacterium tuherenlesis infection occurred in patticnt no. 11, and Pnetumocystis carinit pneumonia in patient no. 9. Three of eight progressors (no. 12, 14. and 8) had remained AIDS-free and without signs of other HIV-related discalse.(CDC-A2) until the beginning of the study. No individuals hat ongoing acute discalses when virologic examinations were performed at study entry. Six months after the beginning of the study. full-blown AIDS occurred in two additional pattents: progressive multifocal leukoenkephalopathy in no. 14 and $P$ carimii pneumonia in no. 1.5. Antiretroviral therapy and prophylaxis for $P$ carinii pneumonia had been administered after the decline of CD4t T cells to less than 300 cells/uL in all but two controls (no. 14 and 15). Both progressors and LTNPs with hemophilia $A$ have been receiving monoclonally purified, high-purity factor VIII concentrate since July 1993, when this product became available in Italy.

PBMCs and CD8-Depleted PBMCs From HIV-Infected Individuals. Peripheral venous blood was collected on both heparin and EDTA. Platsmal wals prepared by two rounds of centrifugation at $560 \mathrm{~g}$ at $4^{\circ} \mathrm{C}$ for 10 minutes, and it was stored in small aliquots at $-80^{\circ} \mathrm{C}$. PBMCs were prepared by centrifugation on a Ficoll-Hypacque density gradient (Pharmacia Biotech. Uppsala, Sweden). Aliguots of $1 \times 10^{\prime \prime}$ cells were washed wice with phosphate-buffered saline. and pellets were obtained by centrifugation at $1 .(8.3 \mathrm{~g}$ for 10 minutes and frozen at $-80^{\circ} \mathrm{C}$ for proviral DNA and viral RNA measurements. PBMCs were washed three times with medium and immediately used for viral isolation. To improve the efficiency of HIV replication. CD8+ cells (mostly $T$ lymphocytes and natural killer cells) were depleted from patients" PBMC.s by immunomannelic beads (Dy'natech: Dynal. Oslo. Norway). Freshly isolated PBMCs were resuspended at 20) $\times 10^{\circ} / \mathrm{mL}$ and incubated with $1 \mathrm{~mL}$ immunomagnetic beads conjugated with an anti-CD8 monoctonal antibody at a ratio of one PBMC per seven beads, as recommended by the manufacturer. After 30 minutes of incubation on ice, cell suspensions were depleted of the CD8+ fraction by a magnet. Cells were washed twice with phosphate-buffered saline containing $2 \%$ fetal call serum. and phenotype was analyzed after immunostaining with CD3/CD4. CD 3/CD8. CD14. and CD16 monoclonal antibody (Coulter Corp). Hialeah. FL) by an Epics Elite cell sorter (Coulter). CD8-depleted PBMCs contaned less than 2\% CD8+ cells after a single round of purification (data not shown).

HIV Isolation. Virus was recovered by cocultivation of patients PBMCs or CD8depleted PBMCs with phytohemagglutinin $5 \mu \mathrm{g} / \mathrm{mL}$ of (PHA-P: Sigma Chemical Corp. St Louis, MO)-activated PBMCs from uninfected individuals. Two per 10" PBMCs or CD8depleted PBMCs were cocultivated with a 1:1 mixture of $6 \times 10$ " PHA blasts from lwo dif- 
ferent donors, and resuspended in $12 \mathrm{~mL}$ RPMI 1640 (Bio- Whittaker, Verviers, Belgium) medium containing $10 \%$ fetal calf serum (Sigma) and $20 \mathrm{U} / \mathrm{mL}$ recombinant interleukin-2 (|IL-2| Boehringer, Mannheim, Germany: complete medium) in T25 flasks (Falcon; Becton Dickinson Labwatre, Lincoln Park, NJ). Five milliliters of culture supernatants were collected twice per week and stored at $-80^{\circ} \mathrm{C}$. Fresh complete medium was replaced on a weekly basis, and the cultures were evaluated for a total of 4 weeks. $\mathrm{Mg}^{2 \pm}$ dependent reverse transcriptase (RT) activity was measured in the culture supernatants. ${ }^{31}$ At peak RT activity, small aliquots of the culture supernatants were stored at $-80^{\circ} \mathrm{C}$ (primary $\mathrm{HIV}$ isolates). Supematants from cocultures that were negative for RT activity were tested for the presence of HIV-1 p24 Ag by a commercially available kit (Coulter). Viral isolation was also attempted from fresh plasma samples collected in the presence of heparin within 30 minutes of isolation. Four milliliters of plasma was added to a $1: 1$ mixture of $6 \times 10^{\text {h }} \mathrm{PHA}$ blasts from two different uninfected individuals and the cultures were maintained for 4 weeks, as already described for viral isolation from PBMCs.

Virus Phenotype.The ability of primary HIV isolates to induce syncytia was tested on the human T-lymphotropic virus-1-transformed MT-2 cell line. ${ }^{22}$ One hundred microliters of viral stocks were used to infect MT-2 cells in 24-well plates (Falcon) containing $2 \times 10^{4}$ cells in $1 \mathrm{~mL}$ RPMI 1640 supplemented with 10\% fetal calf serum. One hundred microliters of a positive control generated by transfection of the infectious molecular clone pNL4-3 in HeLa cells ${ }^{31}$ was tested on MT-2 cells in parallel with the patients' isolates. Cultures were monitored daily for syncytia by an inverted light microscope (Olympus Optical Co, Europa, Hamburg, Germany), and RT activity was measured in the culture supernatant to validate whether the absence or presence of syncytia was correlated with a productive infection. Full concordance was observed between the ability of HIV to induce syncytia in MT-2 cells and to give rise to a productive infection as determined by RT or p24 Ag determination (data not shown).

Quantitation of Proviral HIV-1 DNA Molecules. Cellular DNA was obtained from pellets of $10^{\circ}$ PBMCs by lysis in a saline solution containing proteinase $\mathrm{K}$ and detergents." Absolute quantitation of the proviral copies present in 10 PBMCs was performed by competitive polymerase chain reaction (PCR) using the plasmid pSKAN, which contains an 18-bp deleted fragment of the gag region amplified by the primers SK38 and SK39.34 Cell-associated HIV DNA was amplified in the presence of different concentrations of competitor DNA (namely 2,500, 500, 100 and 20 copies) in separate tubes. Amplification and quantitation were performed as previously described.

Quantitation of Genomic Viral RNA in PBMCs and Plasma. Specific HIV-1 transcripts were directly extracted from pellets of 1 to $2 \times 10^{\prime \prime}$ PBMCs by a previously described single-step method." Genomic HIV-1 RNA present in plasma samples was obtained after ultracentrifugation at $4^{\circ} \mathrm{C}$ for 1 hour at $30,000 \mathrm{rpm}$ (rotor TFT 65.13 ; Kontron, 
Milan, Italy), and extraction of pelleted virions was performed as previously described ${ }^{33}$ RNA pellets were resuspended in $100 \mu \mathrm{L}$ diethyl pyrocarbonate-treated water, and the nucleic acid concentration in $10^{5}$ PBMCs or $100 \mu \mathrm{L}$ plasma was measured. Quantitation of viral transcripts and cell-free viral genomes was achieved by competitive RT-PCR using the pSKAN-derived RNA competitor. ${ }^{35}$ Wild-type RNA was mixed with different concentrations of competitor RNA $(6,250,1,250,250,50$. and, in some cases, 10 copy numbers) in separate tubes. Of note, RNA plasma samples from hemophilic controls had to be diluted to achieve optimal competition. Reverse transcription, PCR amplification, post-PCR procedures, and quantitative analysis of PCR products were performed as described elsewhere. ${ }^{3,3}$

Cell Activation and Chemokine Determination. PBMCs or CD8-depleted PBMCs from some LTNPs were resuspended in RPMI 1640 plus $10 \%$ fetal calf serum, stimulated by PHA plus IL-2 $(20 / \mathrm{U} \mathrm{mL})$, and seeded at $1 \times 10^{\circ}$ cells in 24 -well plates (Falcon). Culture supernatants were collected 3 days after stimulation and stored at $-80^{\circ} \mathrm{C}$ until tested for the presence of chemokines. Chemokine concentrations were measured either by commercially available enzyme-linked immunosorbent assay (ELISA) kits (R\&D Systems Inc, Minneapolis, MN) in the case of RANTES, MIP-1 $\alpha$, and MIP- $1 \beta$ or by a noncommercial ELISA based on anti-MCP-1 or anti-IL-8 monoclonal antibody-coated plastic plates. ${ }^{36,37}$

\section{Results}

HLA Typing in LTNPs and Controls. HLA class I and II phenotypes were determined by standard serologic typing in LTNP and control HIV-infected hemophiliacs (Table $1)$.

Given the small number of individuals studied, no conclusions can be drawn on the potential role of $\mathrm{MHC}$ genes in determining lack of disease progression, as suggested by other studies. $^{13,14}$

Viremia and Cell-associated RNA and Proviral DNA. A broad range of viremia levels (between 9,147 and 1,499,843 copies of HIV-1 RNA/mL plasma) characterized individuals with progressing HIV disease. Approximately 300,000 copies $/ \mathrm{mL}$ were associated with this condition in this cross-sectional analysis (Table 2). In sharp contrast, LTNPs were characterized by levels of HIV-1 viremia consistently less than 10,000 genome molecules/mL plasma as determined by quantitative PCR (between 10 and 8,108 copies), with an approximate mean of 2,500 copies (Table 2). These results are consistent with those reported by Cao et $a l$," who indicated a range between less than 630 and 11,549 HIV RNA copies/mL plasma in LTNP homosexuals and intravenous drug users.

We also compared levels of HIV expression in the peripheral blood compartment (number of copies of full-length HIV RNA per $10^{4}$ cells) and viral load (number of copies of provi- 
al DNA per 10 cells) in PBMCs obtained from LTNPs and progressors. As observed in terms of viremia, a clear-cul difference was observed for both of these parameters between the wo groups of individuals. Approximately 800 copies of full-length HIV transcripts per 10 cells were found in progressors. in contrast to about 36 copies in equivalent numbers of PBMCs from LINPS. The proviral DNA load was 10-fold lower in PBMCs of LINPs than in cells of progressors (Table 2). Of note, the ratio between the level of HIV transcripts and proviral DNA in PBMCs of LTNPs differed substantially from that of progressors. An average ratio of 0.9 (range, 0.1 10 1.3 ) was found in

Table 2. Viral load in LTNP and progressor hemophiliacs

\begin{tabular}{|c|c|c|c|c|}
\hline \multirow{2}{*}{ Patient No } & \multirow{2}{*}{$\begin{array}{l}\text { Plasma* } \\
\text { RNA }\end{array}$} & \multicolumn{3}{|c|}{$\mathrm{PBMC}^{\circ}$} \\
\hline & & RNA & Proviral DNA & RNAVDNA \\
\hline \multicolumn{5}{|l|}{ LTNPS } \\
\hline 1 & 1.750 & 13 & 11 & 1.2 \\
\hline 2 & 3.840 & 76 & 37 & 2.0 \\
\hline 3 & 8,108 & 144 & 110 & 1.3 \\
\hline 4 & 149 & 2 & 17 & 0.1 \\
\hline 5 & 1.280 & 12 & 28 & 0.4 \\
\hline 6 & 2.120 & 3 & 17 & 0.2 \\
\hline 7 & 10 & 1 & 1 & 1.0 \\
\hline Mean & 2.465 & 36 & 32 & 0.9 \\
\hline \multicolumn{5}{|c|}{ Progressors } \\
\hline 8 & 100.654 & 50 & 137 & 0.4 \\
\hline 9 & 9.149 & 78 & 18 & 4.3 \\
\hline 10 & $1,499,843$ & 1,933 & 397 & 4.9 \\
\hline 11 & 40.537 & 512 & 346 & 1.5 \\
\hline 12 & 18.300 & 292 & 251 & 1.2 \\
\hline 13 & 164.352 & 951 & 753 & 1.3 \\
\hline 14 & 78.870 & 1,978 & 574 & 3.5 \\
\hline 15 & 364,467 & 678 & 300 & 2.3 \\
\hline Mean & 284.521 & 809 & 347 & 2.4 \\
\hline
\end{tabular}

Number of copies calculated per ml plasma ${ }^{*}$ or per $10^{5}$ total PBMCs. PBMCs of LTNPs, whereas progressing individuals had a mean ratio of 2.4 (ringe, 0.4 to 4.9 ), with seven of eight subjects showing a positive value (Table 2).

HIV Isolation and Phenotype. The results of our attempts to isolate virus from total PBMCs or CD8depleted PBMCs of LTNPs and progressors are shown in Table 3 . Supernatants from the coculture were first tested for the presence of RT activity, in that this enzyme is $99 \%$ particle-associated and its measurement is therefore a reliable index of virion production. "twis However. this method is substantially less sensitive than determination of p24 Ag by commercially available kits. We therefore performed p24 Ag determinations on culture supernatants that were negative for RT activity. PBMC-associated virus could be successfully recovered from eight of eight individuals with progressive disease but only from iwo of seven LTNPs (patients no. 2 and 6), as measured by RT activity. Virus isolation from PBMCs was demonstrated by $24 \mathrm{Ag}$ determination in one additional LTNP (no. 3. Table 3). Depletion of CD8+ T cells from PBMCs was performed on cells that did not produce virus during cocultivation with PHA blasts. By this approach. two additional LTNP isolates were obtained, as demonstrated either by RT activity (patient no. 5) or p24 
$\mathrm{Ag}$ (no. 7) detection (Table

3). Plasma-associated HIV was isolated from six of eight progressors, whereas no isolates were obtained from LTNP plasma (Table 3).

HIV isolates from progressors and LTNPS were studied for the capacity to replicate and fom syncytia in MT-2cells." Four of live HIV isolates obtained from PBMCs or CD8-depleted PBMCs of LTNPs neither replicated nor induced syncytia. and were therefore classified as NSI (Table 3). Four of eight isolates obtained from progressors PBMCs were also NSI (Table 3), in agreement with previous studies. "Five of six isolates from progressors" plasma samples were found to be NSI. Of note, in
Table 3. Isolation and phenotype of primary HIV isolates obtained from plasma, PBMCs, and CD8-depleted PBMCs of LTNP and progressor hemophiliacs

\begin{tabular}{|c|c|c|c|c|c|c|}
\hline \multirow{2}{*}{$\begin{array}{l}\text { Patient } \\
\text { No. }\end{array}$} & \multicolumn{2}{|c|}{ Plasma } & \multicolumn{2}{|c|}{ PBMCs } & \multicolumn{2}{|c|}{ CD8-Depleted PBMCS } \\
\hline & RT & $\overline{p 24 \mathrm{Ag}}$ & RT & p24 Ag & $\mathrm{RT}$ & p24Ag \\
\hline \multicolumn{7}{|l|}{ LTNPS } \\
\hline 1 & - & - & - & - & - & - \\
\hline 2 & - & - & SI & & & \\
\hline 3 & - & - & - & NSI & & \\
\hline 4 & - & - & - & - & - & - \\
\hline 5 & - & - & - & - & NSI & \\
\hline 6 & - & - & NSI & & & \\
\hline 7 & - & - & - & - & - & NSI \\
\hline \multicolumn{7}{|c|}{ Progressors } \\
\hline 8 & NSI & & NSI & & & \\
\hline 9 & - & - & NSI & & & \\
\hline 10 & - & - & NSI & & & \\
\hline 11 & NSI & & NSI & & & \\
\hline 12 & NSI & & SI & & & \\
\hline 13 & NSI & & SI & & & \\
\hline 14 & s! & & SI & & & \\
\hline 15 & NSI & & SI & & & \\
\hline
\end{tabular}

Viral isolation was attempted by cocultivation of either plasma or cells from HIV-infected individuals with a mixture of PHA blasis of 2 independent donors. Viral phenotype observed by cultivation of MT-2 cells with HIV isolates. 3 ? certain cases (no. 12,13, and 15), a different and more in vitro aggressive (SI) isolate was obtained from PBMCs compared with plasma (Table 3).

HIV Isolation from PBMCs and Other Virologic Parameters in LTNPS. Although the number of LTNPs in our study is small, we have investigated whether the ability to isolate HIV from their total PBMCs (therefore encompassing CD8+ cells with inhibitory capacity for HIV replication $)^{50.41 .11}$ was associated with higher levels of viral load and replication. LTNPs with a positive HIV isolation from unfactionated PBMCs (Table 2) had approximately sixfold higher amounts of HIV RNA in the plasma compared with LTNPs who were either negative for HIV isolation or who were positive only after depletion of CD8+ cells (Fig 2). Eleven-fold and four fold higher levels of expression of cell-associatted HIV RNA and proviral DNA load. respectively. were also associated with a positive HIV isolation from unfactionated PBMCs of LTNPs (Fig 2). Due to the small number of 
Fig. 2. Correlation between HIV replicative parameters and viral isolation from unfractionated PBMCs of LTNP hemophiliacs.
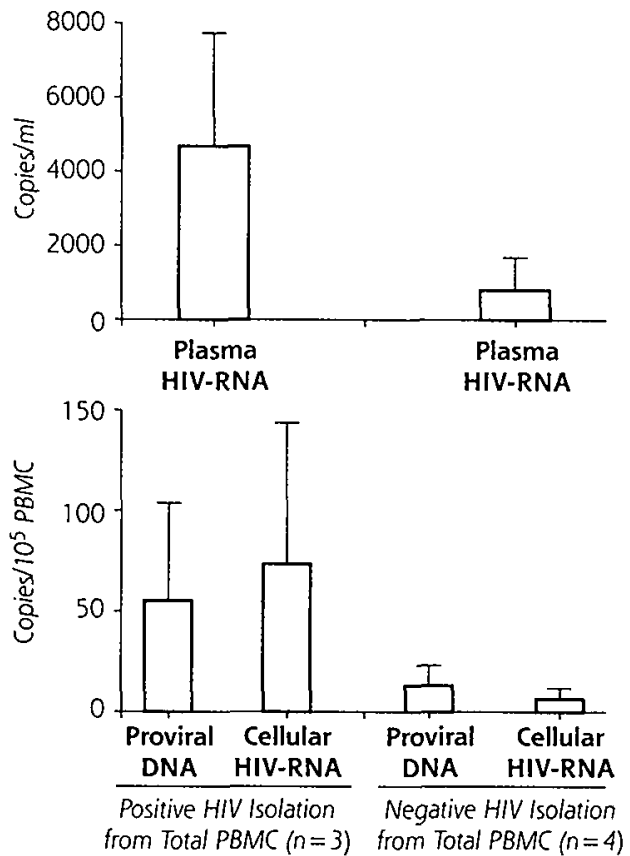

Individuals who either were negative for HIV isolation from total PBMCs or became positive only after depletion of $C D 8+$ cells showed lower levels of virus replication in plasma and PBMCs and a smaller number of proviral DNA copies than subjects who were positive for viral isolation from unfractionated PBMCS.
LTNPS (three isolation-positive $v$ four isolation-negative), statistical analysis was not performed.

In vitro Chemokine Production from PBMCs and CD8-depleted PBMCS of LTNPS. Certain chemokines of the $\mathrm{C}-\mathrm{C}$ family, such as RANTES, MIP- $1 \alpha$, and MIP- $1 \beta$, have been recently shown to be produced by activated $\mathrm{CD} 8+\mathrm{T}$ cells $\mathrm{s}^{20}$ and to suppress HIV replication both in the PMI cell line and in primary cells infected in vitro with HIV: ${ }^{212 \times 2 x}$ Based on these findings, their role as the predominant mediator of the previously described phenomenon of CD8-dependent nonlytic suppression of HIV replication ${ }^{* 2,31}$ has been claimed. ${ }^{20}$ In addition, increased in vitro secretion of these three chemokines has been observed in CD8-depleted cells of some individuals who had remained HIV-negative despite multiple sexual exposures to the virus, and has been correlated with a relative resistance of the $\mathrm{CD} 4+\mathrm{T}$ cells to in vitro infection by NSI viruses. ${ }^{21}$ We therefore have evaluated the concentrations of RANTES, MIP- $1 \alpha$,

and MIP- $1 \beta$, as well as the $\beta$-chemokine MCP- 1 and the $\alpha$-chemokine IL- 8 , after activation of both PBMCs and CD8-depleted PBMCs of some LTNPs by PHA plus IL-2. No substantial differences were observed in the concentrations of these different chemokines in the presence or absence of CD8+ lymphocytes, even in cases (no. 5 and 7) where HIV isolation was simultaneously accomplished exclusively by removal of CD8+ cells (Fig 3). Because our patients, LTNPS and progressors, were all chronically infected with HCV and because whether HCV infection may affect chemokine production is currently unknown, we cannot rule out the possibility that the results shown here have been influenced directly or indirectly by this second pathogen. 


\section{Discussion}

In the present study, we describe the virologic characteristics of a homogeneous group of HIV-infected individuals affected by hemophilia and with progressive or nonprogressive (LTNP) infection. LTNPS showed significantly lower viral load and replication as determined by quantitative PCR, with 100-fold, 20-fold, and 10-fold lower levels of HIV plasma viremia, PBMC-associated full-length HIV-1 RNA, and proviral DNA, respectively, compared with progressors. HIV was never rescued from LTNP plasma, whereas six plasma isolates were obtained from controls. HIV was isolated from unfractionated PBMCs of all progressors, and from three of seven LTNPs. The ability to isolate HIV from PBMCs of LTNPs was correlated with higher in vivo le-vels of HIV load and replication.

Two additional isolates were obtained from PBMCs of two LTNPs after depletion of CD8+ cells. Several chemokines, including those re-

Fig. 3. Chemokine concentrations in supernatants of PBMCs and CD8-depleted PBMCs of LTNPs stimulated with PHA (5 $\mu \mathrm{g} / \mathrm{mL})$ for 72 hours of culture.
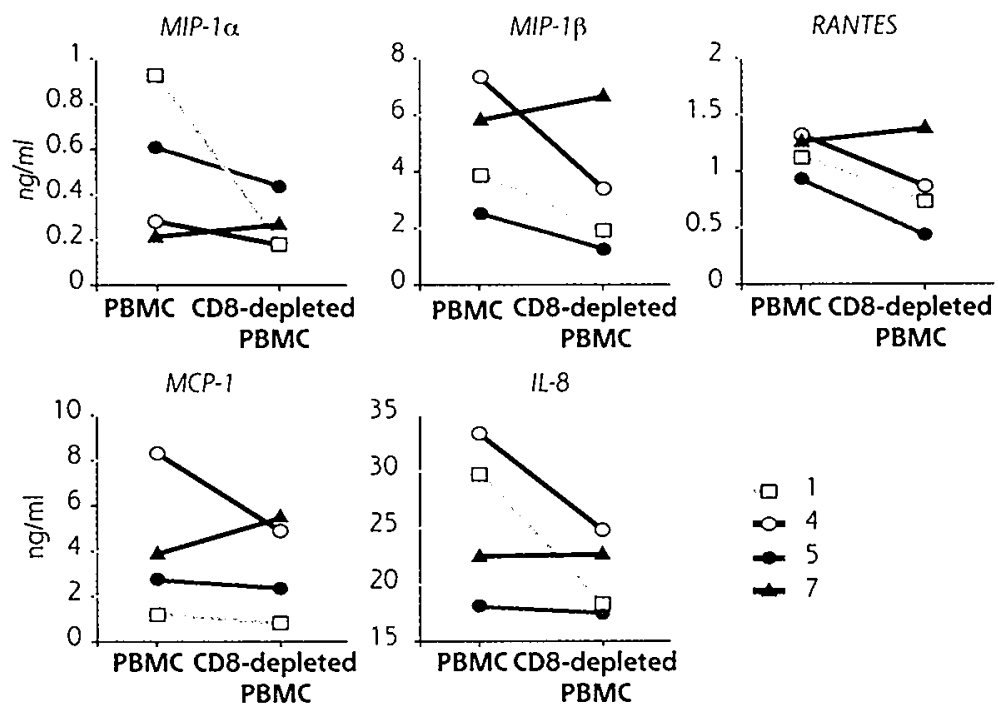

Open symbols, HIV isolation positivity from total PBMCs; closed simbols, HIV isolation negativity from unfractionated PBMCs, which either became positive after removal of CD8+ cells (no. 5 and 7$)$, or remained negative (no. 4). No specific patterns of chemokine accumulation in the presence or absence of $C D 8+$ cells were observed. Lower levels of chemokines were observed in cultures of LTNP hemophiliacs afier 6 days of culture, whereas comparable levels of chemokines were produced in stimulated PBMC cultures established from uninfected donors. cently reported to act as CD8-derived HIV-suppressor factors, ${ }^{\text {"1 }}$ were detectable in supernatants of cultures established from both PBMCs and CD8-depleted PBMCs of LTNPs. However, no obvious correlations between culture supernatant-associated chemokine levels and the presence or absence of CD8+ cells were observed, even in cases where HIV isolation was accomplished exclusively after removal of this PBMC subset. 
LTNPs have been described in all risk categories of HIV-infected individuals. At present. the nature of the relatively apathogenic infection in LTNPs remains elusive. However, a 2()(-bp deletion of the nef gene has been reported both in a single hemophiliac and in a cohort of one denor and six transfusion recipients. all showing nonprogressive disease." resembling the attenuated virologic and clinical features of macaques infected with nefdeleled SIV." In contrast. no gross deletions of the nef gene have been reported in PBMCassociated proviral DNA oblained from several other LTNPS."-

Some virologic features are consistent among LTNPs belonging to different risk categories evaluated by different investigators in different areas of the world. Substantially lower levels of HIV load in the plasma, likely reflecting virus produced in lymphoid tissue. have been observed in LTNPs compared with progressors. In this regard, a threshold of approximately 10.000 copies of full-length HIV RNA/mL plasma characterizes our population of LTNPs, in close similarity to the population described in a previous study." whereas substantially higher levels $(70.00()$ copies $/ \mathrm{mL}$ ) of HIV were indicated in the study by Pantaleo e't al." Because the quantitative PCR techniques for estimating HIV RNA in plasma and PBMCs in our study and the latter study are identical. it is more likely that these differences truly reflect distinct populations of infected individuals. In this regard. we have selected a homogeneous group of LTNPs in that most of the patients had a history of more than 12 years since seroconversion. in close similarity to the LTNPs described by Cao et al." Similar considerations can be made by comparison of the viral load and full-length HIV RNA detected in PBMCs in our study and previous studies.

Despite the fact that HIV RNA was present in the plasma of LTNPs. viral isolation was consistently negative. It is unclear at present whether this finding can be considered an indication that defective HIV predominates in LTNPS, or whether it simply reflects a relattively poor sensitivity of the current methods for isolating HIV in comparison to PCRbased technicjues. We could isolate HIV from the plasma of a progressor (patient no. 8) who began to show signs of disease progression at study entry (Fig 1B): of note, this individual had approximately 10 to 50 -fold higher levels of HIV RNA than most LTNPs before disease progression. Another patient (no. 9) was characterized by CD4+ T-cell counts of approximately $20(0 /, 1 \mathrm{~L}$ over the last 4 years and therefore could be defined a slow progressor (Fig 1B). Quantiation of his plasmat-associated HIV showed less than 10.000 copies/mL (Table 2), and HIV isolation from plasma has been repeatedly unsuccessful (Table 3). The virologic state of his PBMCs has confirmed a situation of relative quiescence. with 18 and 78 copies of proviral DNA and transcripts per $10^{\circ}$ PBMCs. respectively (Table 2), although HIV could be isolated by coculivation of unf ractionated PBMCs with allogeneic blasts (Table 3). These two cases (no. 8 and 9) highlight the fact that no absolute distinction can be made between LTNPs and individuals with progressing HIV disease based exclusively on virologic parameters. supporting the view that a continuum exists 
between these two otherwise strikingly diverse outcomes of HIV infection. In contrast to plasma, infectious HIV could be easily obtained from PBMCs of three of seven LTNPS, whereas it was accomplished in a minority of LTNPs described by Cao el al." exclusively after CD8 depletion. Viral isolation was accomplished in seven of seven LTNPs studied by Pantaleo et al." when lymph node mononuclear cells were cocultivated with allogeneic PHA blasts. Unfortunately. no data were reponted in this latter study on the ability to isolate HIV from PBMCs of the same individuals. Our observation that progressor patient no. 8 had a still relatively quiescent virologic state at the PBMC level but high levels of plasma-associated culturable virus supports the view that pathogenic events driven by infectious HIV were occurring in anatomic districts other than the peripheral blood compartment. such as the lymphoid tissue. ${ }^{45}$ A close virologic follow-up study of patient no. 8 will also investigate whether PBMCs will also present evidence of active viral replication (cxpression of full-length HIV RNA) and/or sprcading (proviral DNA copy number) at subsequent determinations.

Of interest, most PBMCs of LTNPs showed RNA/DNA ratios less than or equal to 1. whereas all but one progressor had positive values indicating an active state of virus expression in the PBMCs (Table 2). In this regard. it has been proposed that a state of "true microbial latency" does not exist in HIV infection, ${ }^{\text {s4 }}$ and that the finding of cells infected and not actively expressing HIV may simply reflect the kinetics of the virus life cycle in infected CD4+ T lymphocytes. ${ }^{\text {th }}$ In contrast, other studies ${ }^{\text {t7 }}$ have estimated that the pool of infected cells not expressing HIV at a given time in lymphoid organs, where several factors are in place for favoring viral replication, largely exceeds that of cells actively expressing virus. Our finding that a state of relative quiescent HIV infection characterizes the PBMCs of LTNPs. unlike those of individuals with progressive disease, provides additional evidence of a direct pathogenic link between the extent of virus replication detectable in the peripheral blood compartment and development of AIDS. This concept has found strong supportive evidence in the study by Mellors $e t$ al: ${ }^{\text {sh }}$ showing the power of a single plasma-associated HIV RNA quantitation in predicting the clinical outcome of the patient.

CD8+ cell depletion from the PBMCs of LTNPs has resulted in the rescue of two additional isolates, rcinforcing the observation that these $T$ cells often exert a potent suppressive effect on HIV replication. ${ }^{3(1+1) .11}$ The nature of the suppressive effect has remained elusive for several years, although recent study has begun to shed light on potential mediators. Certain $\beta$-chemokines, namely RANTES, MIP- $1 \alpha$, and MIP-1 $\beta$, are produced by activated $C D 8+T$ cells and cell lines (as well as by many other cell type ${ }^{2 t+14}$ ) and suppressed HIV replication both in the PMI T-cell line and in T-cell blasts of seronegative individuals infected in vitro with different HIV and SIV strains. ${ }^{21}$ The mechanism of action is explained by the ability of certain chemokine receptors to act as coreceptors together with CD4 
for HIV entry. ${ }^{2.2 x}$ In addition, IL-16 has been associated with CD8 nonlytic suppression of virus replication in African green monkeys infected with SIV $_{\text {ugm. }}{ }^{50}$ In light of these findings, we have determined the presence of chemokines in the supernatants of PBMC cultures and CD8-depleted PBMCs of some LTNPs. All three HIV-suppressive chemokines, as well as MCP-1 (belonging to the same family of $\beta$-molecules) and IL- 8 (of the $\alpha$-group of chemokines), were present in detectable amounts in PBMC cultures of LTNPs either directly stimulated by PHA (Fig 3) or cocultivated with allogeneic blasts (not shown). However, no obvious correlations were observed between the presence or absence of CD8+ cells and chemokine concentrations in culture supernatants, and also in those cases where viral isolation was simultaneously accomplished exclusively by removal of CD8+ cells. These results, with the important caveat of noting the small number of individuals who have been evaluated, do not assign a clear-cut role to endogenous chemokines as mediators of CD8-dependent nonlytic suppression of HIV expression during viral isolation. In this regard, PHA-induced production of RANTES, MIP- $1 \alpha$, and MIP- $1 \beta$, at levels higher and more sustained than those herein reported for LTNPs, was demonstrated in supernatants of CD8-depleted PBMCs of two exposed uninfected individuals who were resistant to in vitro infection by NSI HIVs."

The ability to isolate HIV from LTNP PBMCs was inversely correlated with the three virologic parameters investigated in the present study. LTNPs who tested negative for HIV isolation from their PBMCs or who became positive only after CD8+ cell depletion had substantially lower levels of HIV load and replication (cell-associated transcripts) in PBMCs than LTNPs who tested positive (Fig 2). These results reinforce the hypothesis that LTNPs represent a heterogeneous group of individuals, and that virologic markers may represent the best predictors of rapid or slow disease evolution. ${ }^{4 x}$ Molecular analysis of the HIV quasi-species present in vivo and obtained in vitro from this group of hemophiliacs is in progress, with particular focus on the potential presence of variants of the HIV-1 nef allele. ${ }^{15 \cdot 17}$

In conclusion, our study has demonstrated that hemophiliacs with nonprogressive HIV disease are characterized by substantially lower levels of HIV load and replication in the peripheral blood compartment than a matched group of hemophiliacs with progressing HIV disease. Although our study confirms the view that the extent of HIV replication in vivo likely is "the major determinant of pathogenicity," ${ }_{1.43-6,+8.85}$ the immunologic and virologic components involved in either pathogenic or relatively apathogenic HIV infection remain uncovered.

\section{Acknowledgment}

We thank Sergio Bernasconi for the quantitation of MCP-I and IL-8 in culture supernatants. 


\section{References}

1. Fauci AS: Multifactorial nature of human immunodeficiency virus disease: Implications for therapy. Science 262:1011, 1993

2. Clark SJ, Saag MS, Don Decker W, CambellHill S, Roberson JL. Veldkamp PJ, Kappes JC, Hahn BH, Shaw GM: High titers of cytopathic virus in plasma of patients with symptomatic primary HIV-1 infection. $N$ Engl J Med $324: 961,1991$

3. Piatak M, Saag MS, Yang LC, Clark SJ, Kappes JC. Luk KC, Hanh BH, Shaw GM, Lifson JD: High levels of HIV-1 in plasma during all stages of infection determined by competitive PCR. Science 259:1749, 1993

4. Daar ES, Moudgil T, Mcycr RD, Ho DD: Transient high levels of viremia in patients with primary human immunodeficiency virus type 1 infection. N Engl I Med 324:954, 1991

5. Graziosi C. Pantaleo G. Butini L, Demarest JF, Saag MMS. Shaw GM, Fauci AS: Kinetics of human immunodeficiency virus type 1 (HIV-1) DNA and RNA synthesis during primary HIV-1 infection. Proc Narl Acad Sci USA 90:6405.1993

6. Clementi M, Bagnarelli $P$, Menzo S, Valenza A. Manzin A, Varaldo PE: Clearance of HIV-1 viremia after seroconversion. Lancet 341:315, 1993

7. Phillips AN: Reduction of HIV concentration during acute infection: Independence from a specific immune response. Science 271:497. 1996

8. Buchbinder SP, Katz MH. Hessol NA. O'Malley PM. Holmberg SD: Long-term HIV1 infection without immunologic progression. AIDS 8:1/2.3. 1994

9. Easterbrook PJ: Non-progression in HIV infection. AIDS 8:1179. 1994

10. Cao Y, Qin L, Zhang L. Safrit J, Ho DD: Virologic and immunologic characterization of long-term survivors of human immunodefi- ciency virus 1 infection. $N$ Engl. $/$ Med $332: 201,1995$

11. Pantaleo G. Menzo $S$, Vaccarezza $M$. Graziosi C, Cohen OJ, Demarest JF, Montefiori D. Orenstein JM, Fox C, Schrager LK, Margolick JB, Buchbinder S, Giorgi JV, Fauci AS: Studies in subjects with long-term nonprogressive human immunodeficiency virus infection. N Engl I Med 332:209. 1995

12. Klein MR, van Balalen CA. Holwerda AM, Kerkhof Garde SR. Bende RJ, Keet IPM, Eeftinck-Schattenkerk JKM, Osterhaus ADME, Schuitemaker H, Miedema F: Kinetics of Gagspecific cytotoxic $T$ lymphocyte responses during the clinical course of HIV-1 infection: A longitudinal analysis of rapid progressors and long term asymptomatics. $J$ Exp Med 181:1365, 1995

13. Itescu S, Rose S, Dwyer E. Winchester R: Certain HLA-DR5 and DR6 major histocompatibility complex class II alleles are associated with a CD8 lymphocytic host response to human immunodeficiency virus type I characterized by low lymphocyte viral strain heterogeneity and slow disease progression. Proc Nall Acad Sci USA 91:11472, 1994

14. Kaslow RA, Carrington M. Apple R, Park L, Munoz A. Saah AJ, Goedert JJ, Wimkler C, O'Brien SJ, Rinaldo C, Detels R. Blattner W, Phair J, Erlich H, Mann DL: Influence of combinations of human major histocompatibility complex genes on the course of HIV-1 infection. Nat Med 2:405, 1996

15. Kirchhoff F, Greenough TC, Brettler DB, Sullivan JL. Desrosiers RC: Brief report: Absence of intact nef sequences in a longterm survivor with nonprogressive HIV-1 infection. N Engl J Med 332:228, 1995

16. Deacon NJ. Tsykin A, Solomon A, Smith K, Ludford-Menting M, Hooker DJ, McPhee DA, Greenway AL, Ellett A, Chatfield C, Lawson 
VA, Crowe S. Maem A. Sonza S. Learmont J. Sullivan JS, Cunningham A. Dwyer D. Dowion D. Mills J: Genomic structure of an attenuated quasi species of HIV-1 from a blood transfusion donor and recipients. Science $270: 988$. 199.5

17. Kestler HW III. Ringler DJ. Mori K. Panicali DL. Schgal PK. Danicl MD. Desrosier R: Importance of the nef gene for maintenance of high virus loads and for development of AlDS. Cell 6.5:0.51. 1991

18. Verani P. Mariant G. Mannucci PM. De Rossi G. Nicoletti L. Titti F. Falcione E. Pasqualetti D. Ammassari M. Gringeri A. Mandelli F. Rossi GB: Prevalence of HTLVIII/LAV antibodies in Italian asymptomatic hemophiliacs given commercial concentrates of factors VIII and IX. I Med Virol /9:/43. 1980

19. Gringeri A. Mannucei PM. MedicalScientific Committee of the Fondazione dell'Emofilia: National Survey of HIV Infection in Italian Hemophiliacs: 1983-1987. Ric Clin Lab /8:75, 1988

20. Coechi F. DeVico AL, Garzino-Demo A. Arya SK. Gallo RC. Lusso P: Identification of RANTES, MIP-1 $\alpha$, and MIP- $1 \beta$ as the major HIV-suppressive factors produced by $\mathrm{CD} 8^{+} \mathrm{T}$ cells. Science 270:1811, 1995

21. Paxton WA, Martin SR. Tse D. O Brien TR. Skurnick J. VanDevanter NL. Padian N. Braun JF, Koller DP, Wolinsky SM, Koup RA:

Relative resistance to $\mathrm{HIV}-1$ infection of CD4 lymphocytes from persons who remain uninfected despite multiple high-risk sexual exposures. Nat Med 2:412.1996

22. Feng Y. Broder CC. Kennedy PE. Berger EA: HIV-1 entry cofactor: Cloning of a seventransmembrane $\mathrm{G}$ protein-coupled receptor. Science 272:872.1996

23. Deng H. Liu R. Eimeler W. Choe S. Unutmaz D. Burkhart M. Di Marzio P. Marmon S. Sutton RE. Hill CM. Davis CB. Pelper Holm-
SC. Schall TJ. Lituman DR. Landau NR: ldentification of a major co-receptor for primary isolates of HIV-1. Namure 381:661, 1996 24. Dragic T. Litwin V. Allaway GP, Martin SR. Huang Y. Nagashima KA. Cayanan C. Maddon PJ. Koup RA. Moore JP. Paxton WA: HIV-1 entry into $\mathrm{CD}^{+}$cells is mediated by the chemokine receptor CC-CKR-5. Nantre 351:667. 1996

25. Choc H. Farzan M. Sun Y. Sullivan N. Rollins B. Ponath PD. Wu L. Mackay CR. LaRosa G. Newman W. Gerard N, Gerard C. Sodroski J: The $\beta$-chemokine receptors CCR3 and CCR5 facilitate infection by primary HIV isolates. Cell 85:/135, 1996

26. Doranz BJ, Rucker J. Yi Y. Smyth RJ. Samson M. Peiper SC. Parmentier M. Collman RC. Dooms RW: A dual-tropic primary HIV-1 isolate that uses fusin and the b-chemokine receptors CKR-5, CKR-3, and CKR-2b as fusion cofactors. $C(1 / 85: 1 / 49,1996$

27. Alkhatib G, Combadiere C. Broder CC. Feng Y, Kennedy PE, Murphy PM. Berger EA: CC CKR5: A RANTES, MIP-1 $\alpha$, MIP-1 $\beta$ receptor as a fusion cofactor for macrophagetropic HIV-1. Science 272:1955. 1996

28. Ghezzi S. Alfano M. Delfanti F. Biswas P. Lazzarin A. Mantovani A. Poli G. Vicenzi E: Chemokines and HIV: More than just suppression. I ADDS (in press)

29. Santagostino E. Gringeri A. Cultraro D. Tradati F. Siracusano L. Marinoni A. Mannucci PM: Factors associated with progression to AIDS and mortality in a cohort of HIV-infected patients with hemophilia followed up since seroconversion. $\mathrm{Co} / \mathrm{MO} / \mathrm{Biol}+1: 37 /$. 1995

30. Centers for Discase Control and Prevention. Morb Mortal Weekly Rep 41:1. 1992

31. Vicenzi E. Dimitrov DS. Engleman A. Migone TS. Purcel! DFJ. Lconard J. Englund G. Martin MA: An integration defective US deletion mutant of $\mathrm{HIV}-1$ reverts by eliminating 
additional LTR sequences. I Virol 68:7879. 1994

32. Koot M. Vos AHV. Keet RPM. De Goede REY. Dercksen W. Terpstra FG, Coutinho RA. Miedema F. Tersmette M: HIV-1 biological phenotype in long term infected individuals, evaluated with an MT-2 cocultivation assay. AIDS 0.49 .1992

33. Bagnarelli P. Menzo S. Manzin A. Varaldo

PE. Montroni M. Giaccia M. Clementi M:

Detection of human immunodeficiency virus type-1 transcripts in peripheral blood lymphocytes by the polymerase chain reaction. I livol Methods.32:3/. 1991

34. Menzo S. Bagnarelli P. Giacea M. Manzin A. Varaldo PE. Clementi M: Absolute quantitation of viremia in human immunodeficiency virus infection by competitive reverse transcription and polymerase chain reaction. I Clin Microbiol 30:1752.1992

35. Bagnarelli P. Menzo S. Manzin A. Giacca $M$. Varaldo PE. Clementi M: Detection of human immunodeficiency virus type-1 genomic RNA by reverse-transcription polymerase chain reaction. I Med Virol i4:89.1995 36. Peri G. Milanese C. Matteucci C. Ruco L. Zhou D. Sozzani S. Coletta I. Mantovani A: A new monoclonal antibody (5D3-F7) which recognizes human monocyte-chemotactic protein-1 but not related chemokines. Development of a sandwich ELISA and in situ detection of producing cells. $/$ /mmmmol Methods 174:249, 1994

37. Bernasconi S. Cinque P. Peri G. Sozzani S. Vicenzi E. Crociati A, Lazzarin A. Poli G. Mantovani A: Selective elevation of monocyte chemotactic protein-1 (MCP-1) in the cerebrospinal fluid of AIDS patients with cytomegalovirus encephalitis. I Infect Dis (in press)

38. Fernie BF. Poli G. Fauci AS: Alpha interferon suppresses virion but not soluble human immunodeficiency virus antigen production in chronically infected T-lymphocytic cells. . Virol 65:968. 1991

39. Schuitemaker H. Koot M. Koostra NA. Dercksen MW, De Goede REY, Vin Steenwijk RP. Lange JMA, Eeltink Schattenkerk JKM. Miedemil F. Tersmette M: Biological phenotype of human immunodeficiency virus type 1 clones at different stages of infection: Progression of disease is associated with a shift from monocytotropic to $\mathrm{T}$ cell -tropic virus populations. I Virol 66:1354. 1992 40. Levy JA. Mackewic\% CE. Barker E: Controlling HIV pathogenesis: The role of noncytotoxic anti-HIV response of $\mathrm{CD}^{+} \mathrm{T}$ cells. Immmol Today 17:2/7. 1996

41. Walker CM, Moody DJ. Stites DP. Levy JA: $\mathrm{CD}^{+}$lymphocytes can control HIV infection in vitro by suppressing virus replication.

Science 2.34:1563.1986

42. Huang Y. Zhang L. Ho DD: Biological characterization of nef in long-term survivors of human immunodeficiency virus type 1 infection. J Virol 69:8142.1995

43. Wei X. Ghosh SK. Taylor ME. Johnson VA. Emini EA. Deutsch P. Lifison JD. Bonhoeffer S. Nowak MA. Hahn BH. Saag MS. Shaw GM: Viral dynamics in human immunodeficiency virus type 1 infection. Nature 373:117. 1995 44. Ho DD. Ncumann AU. Perelson AS. Chen W. Leonard JM.Markowitz M: Rapid turnover of plasma virions and CD4 lympho cytes in HIV-1 infection. Nature 373:123.1995

45. Pantaleo G. Graziosi C. Demarest JF. Butini L. Montroni M. Fox CH. Orenstein JM. Kotler DP. Fauci AS: HIV infection is active and progressive in lymphoid tissue during the clinically latent stage of disease. Nanure $362: 355$. 1993

46. Colfin JM: HIV population dynamics in vivo: Implication for genetic variation, pathogenesis, and therapy. Scicnce 267:483.1995 47. Embretson J. Zupancic M, Ribas JL. Burke A. Racz P. Tenner-Racz K. Haase AT: Massive 
covert infection of helper T lymphocytes and macrophages by HIV during the incubation period of AIDS. Nanure 362:359.1993

48. Mellors JW, Rinaldo CR Jr, Gupta P. White RM, Todd JA, Kingsley LA: Prognosis in HIV1 infection predicted by the quantity of virus in plasma. Science 272:1157,1996

49. Mantovani A, Sozzani S. Proost P. Van Damme J: The monocyte chemoattractant protein family, in Horuk R (ed):

Chemoattractant Ligands and Their

Receptors. Boca Raton, FL. CRC. 1996, pp

169-192

50. Baier M, Werner A. Bannert N, Metzner K, Kurth R: HIV suppression by interleukin-16. Nature 378:563, 1995

51. Paul $W$ : Can the immune response control HIV infection? Coll $\$ 2: 177,1995$ 


\section{$\mathrm{C}-\mathrm{C}$ chemokines, pivotal in protection against HIV type 1 infection}

'D. Zagury, 'A. Lachgar, 'V. Chams, 'L.S. Fall, 'J. Bernard, 'J.F. Zagury, 'B. Bizzini, 'A. Gringeri, 'E. Santagostino, ${ }^{4}$ J. Rappaport, ${ }^{5}$ M. Feldman, ${ }^{\circ}$ S.J. O'Brien, ${ }^{7}$ A. Burny, ${ }^{4}$ R.C. Gallo.

'Universitó Pierre et Marie Curie, Paris, France;

2Institut Jean Godinot, Reims, France;

${ }^{3}$ Hemophilia and Thrombosis Center Angelo Bianchi Bonomi,

IRCCS Maggiore Hospital and University of Milan, Italy;

${ }^{4}$ Center for Neuro Virology and Neuro Oncology, Allegheny

University of the Health Sciences, Philadelphia;

sWeizmamn Institute, Rehovot, Israel;

'National Cancer Institute, Frederick;

${ }^{7}$ Université Libre de Bruxelles, Bruxelles, Belgium;

'Institute of Human Virology, University of Maryland

Baltimore.

Proceeding of the National Academy of Sciences USA 95:3857-3861, 1998. 


\begin{abstract}
Exposure to HIV type 1 (HIV-1) does not usually lead to infection. Although this could be because of insufficient virus titer, there is now abundant evidence that some individuals resist infection even when directly exposed to a high titer of HIV. This protection recently has been correlated with homozygous mutations of an HIV-1 coreceptor, namely CCR5, the receptor for the $\beta$-chemokines. Moreover, earlier results already had shown that the same chemokines markedly suppress the nonsyncitial inducing variants of HIV-1. the chief virus type transmitted from person to person. CCR5 mutation, as a unique mechanism of protection. is. however, suspect because HIV-l variants can use other chemokine receptors as their coreceptor. Moreover, recent results have established that infection can indeed sometimes occur with such mutations. Here. we report on transient natural resistance over time of most of 128 hemophiliacs who were inoculated repeatedly with HIV-1-contaminated Factor VIII concentrate from plasma during 1980-1985 before the development of the HIV blood test. Furthermore, and remarkably, 14 subjects remain uninfected to this date. and in these subjects we found homozygous CCR5 mutations in none but in most of them overproduction of $\beta$-chemokines. In vitro experiments confirmed the potent anti-HIV suppressive effect of these chemokines.
\end{abstract}

\title{
Introduction
}

Some of the $\beta$ or $C-C$ chemokines, a subset of the relatively low molecular weight chemoattractant inflammatory cytokines, recently were found to be specific and potent inhibitors of HIV type I (HIV-1) (1) that likely account for the bulk. if not all, of the specific anti-nonsyncitial inducing (NSI) HIV-I suppressive factors secreted by activated immune cells from seropositive individuals (2). They are also produced by human $\mathrm{T}$ cell leukemia/lymphotropic virus type-I-transformed CD8 $T$ cell lines (1). Their protective antiviral effect is directed against most of the tested strains of HIV-1. HIV-2, and simian immunodeficiency virus but not most syncytium-inducing strains of $\mathrm{HIV}-1$ and not against other viruses (1). Subsequent but independent work by Feng et al. (3) showed that the second receptor for HIV-1 is a chemokine receptor (Fusin, CXCR4). a finding quickly confirmed and extended by others to CCR5 (4) and to a lesser extent to some other chemokine receptors (5). Evidence was presented that indicates that the mechanism does not act by interference with signal transduction but by blocking HIV-I interaction with these receptors (6). Recent results have shown that some high risk HIV-I-exposed people had homozygous mutations in the CCR5 receptor (7). suggesting that protection is due to the inability of HIV-1 to infect target cells in the absence of the receptor per se (8). However. recent studies have established that infection can sometimes occur with such mutations (9). Furthermore, as noted above, variants of HIV-I can use more than one co-receptor. These and the earlier results on chemokine suppression of HIV (1) prompted us to study 
the production of $\mathrm{C}$-C chemokines as an effector component of cellular activation and to investigate whether $\mathrm{C}$-C chemokines production or genetic abnormality of their receptors were linked with protection against HIV-I inlection.

\section{Materials and methods}

Reagents. Virus stock. HIV-I consisted of the supernatant (SN) of a permanent cell culture infected with a laboratory NSI virus isolate (Strain Z96. reverse transcriptase activity $\left.=800 \times 10^{2} \mathrm{cpm} / \mathrm{ml}\right)$ or, in some experiments. the $\mathrm{SN}$ of cocultures of peripheral blood mononuclear cells (PBMC) from the primary isolate (AUD) with nomal activated PBMC (reverse transcriptase activity $>3(0) \times 10^{\circ} \mathrm{cpm} / \mathrm{ml}$ ).

Antibodies (Abs). Neutralizing anti-macrophage inflammatory protein (MIP)-l $\ell$ antiMIP-1 $\beta$, and anti-RANTES (MMR) Abs were purchased from $R$ \& D Systems.

Cell Cultures. Cells. PBMC were isolated on Ficoll/Hypayue from heparinized blood. Cell activalion. PBMC (10" cell/ml) were activated for $48 \mathrm{~h}$ with phytohemagglutinin (PHA)-P $(3 \mu \mathrm{g} / \mathrm{ml})$. Culture SN then were collected and stored at $-80^{\circ} \mathrm{C}$.

HIV-1 infection. Forty eight-hour PHA-activated PBMC were pelleted and incubated at room temperature for 90 min with 1 ب 1 of a $1: 10$ dilution of virus stock (NSI strain Z96 or primary isolate AUD) and washed twice. These cells were cultured for 6 days in medium supplemented with interleukin $2(100$ units $/ \mathrm{ml})$.

Assays. Measure of $\mathrm{T}$ cell proliferation. $\mathrm{T}$ cell proliferation. used to evaluate immune activation of PHA-stimulated PBMC. was measured by $3 \mathrm{H}$-thymidine $(0.5 \mu \mathrm{Ci} /$ well $)$ incorporation assaly, which wals added $18 \mathrm{~h}$ before cell harvest. $3 \mathrm{H}$-thymidine incorporation was measured in a $\beta$-counter. All tests were carried out in triplicate. and results are expressed as crude cpm.

SSCP/HA analysis of CCR5 (formerly CKR5) among human genotypes. The CCR.5 primers were used to amplify $100 \mathrm{ng}$ of DNA in the presence of $\alpha_{-}:-\mathrm{P}-\mathrm{dCTP}$, in $10 \mathrm{\mu l}$. as described. The samples were digested by adding 10,11 of $2 X$ Hinfl restriction buffer and 10 units of Hinfl and digesting at $37^{\circ} \mathrm{C}$ for $1 \mathrm{~h}$. A 3-ul portion of the sample was run on a $5 \%$ acrylamide gel (37.5:1 acrylamide:bis-acrylamide) at $50 \mathrm{~W}$ for $3 \mathrm{~h}$ in a $4^{\circ} \mathrm{C}$ cold room. The gel was dried and exposed $10 x$-raly lilm for $16-72 \mathrm{~h}$. The PCR product was puritied from a 50-ul reaction to pCRscript vector (Stratagene), according to the manufacturer's protocol. Clones with inserts were checked by SSCP $(1 \times S S C P=120 \mathrm{mM} \mathrm{NaCl} / 5$ $\mathrm{mM}$ sodium citrate/20 $\mathrm{mM}$ sodium phosphate, $\mathrm{pH}$ 6.8) to identify the clones with altered alleles, and these clones were sequenced by using dye teminators and AmpliTac FS enzyme (Perkin-Elmer). Sequencing reactions were run on an Applied Biosystems 373 machine. The primers CCKF4 and CCKR4 (5'-CTTCTTCAT-CATCCTCCTGACA. TGTAGGGAGCCCAGAAGAGA) were used to amplify the portion of the gene containing the CCR5 532 deletion. Products were resolved on either $2 \%$ agarose gels or $6 \%$ 
Fig. 1. Production of C-C chemokines by PBMC from seronegative individuals

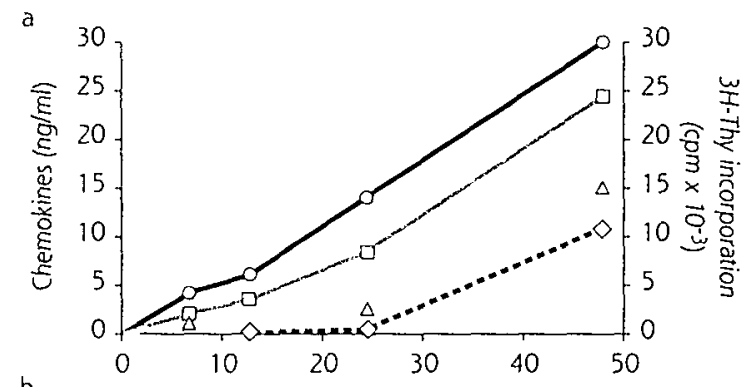

b
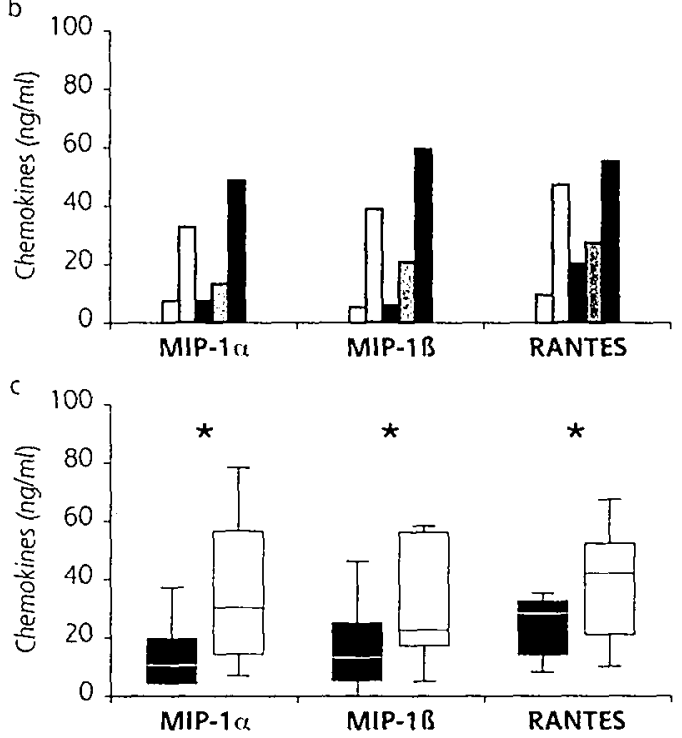

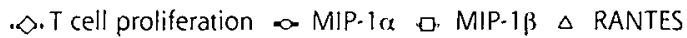

$T$ cell proliferation was assayed by $3 \mathrm{H}$-thymidine test, and C-C chemokine production was measured by ELISA in culture SN. (a) Kinetics of $T$ cell pro-

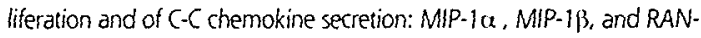
TES. Only background values of chemokines production $(<0.5 \mathrm{ng} / \mathrm{ml})$ and $T$ cell proliferation $(<500 \mathrm{cpm}$ ) were found for resting cells. A representative experiment is shown. (b) Variations of chemokines production by PBMC from five different seronegative donors. (C) Box plot analysis of C.C chemokines production in high risk HEH. HEH (white boxes) compared with control seronegative donors (black boxes). Box limits correspond to $50 \%$ percentile of each group, and the horizontal bar corresponds to the median. Asterisks refer to a statistical difference $(P=0.0063$ for $M P P-1 \alpha$, $P=0.0223$ for $M P P-1 \beta$, and $P=0.0361$ for RANTES). acrylamide gels.

Titration of C-C chemokines. MMR produced by activated cells were measured by ELISA (kits from R \& D Systems) in culture SN of PBMC after $48 \mathrm{~h}$ and of antigen presenting cells after $24 \mathrm{~h}$.

HIV-1 titration. HIV-1 production by in vitro-infected PBMC was assessed by p24 ELISA test.

\section{Results and discussion}

Human sera do not contain reliably measurable amounts of MMR because they aggregate, bind to glassware, stick to carbohydrate moieties present in blood, and are produced by platelets in varying amounts, which may be influenced by the method of blood withdrawal and use. However, their production by blood-derived cells can be assessed readily and reproducibly in culture by ELISA. Resting PBMC did not secrete C-C chemokines at measurable levels. By contrast, upon PHA activation, these cells release consistent amounts of MMR in the culture SN (Fig. 1a). This is also the case after immune activation with anti-CD3/interleukin 2, 1,4-phenylenedi-amine/tetanus toxoid, or Staphylococ-cus enterotoxin B. Thus, as reported for monocytes (U937) and T (Jurkatt) cell lines in which induction of MIP-la expression was obtained only upon cellular activation (10), the C-C chemokine secretion by $\mathrm{PBMC}$ from normal individuals, virtually absent at the resting stage, also 
was induced by cell activation. Levels of production, however, were dependent on the blood donor (Fig. Ib), the type of immune cells (PBMC, purified CD4 or CD8 T cells, antigen presenting cells), the culture conditions, and the mode of stimulation (data not shown). It is note-worthy that (i) $\mathrm{C}$-C chemokine secretion was an early and transient effector component of the cellular response to PBMC activation that preceded $\mathrm{T}$ cell proliferation.

Significant amounts of MIP- $1 \alpha$ and MIP- $1 \beta$ were found in the $12 \pm 6$-h culture SN, before DNA replication that occurred $24-48 \mathrm{~h}$ after activation, as measured by " $\mathrm{H}$-thymidine incorporation (Fig. 1a). After the peak of chemokine release, reached by 48 h, C-C chemokine secretion by activated PBMC (growing in the presence of interleukin 2) markedly dropped to background levels $\left(1-210^{3} \mathrm{mg} / \mathrm{\mu l}\right)$. (ii) Although the production levels of MMR were different in the same individual, they varied according to a similar trend from one subject to another, as if activation induced a coordinated cellular response of the three chemokines (Fig. 1b).

These initial studies demonstrated that reproducible results for quantitative comparison of C-C chemokine production by PBMC from different subjects could be obtained. To study the possible anti-HIV role played by $\mathrm{C}-\mathrm{C}$ chemokines in resistance to $\mathrm{HIV}-1$ infection, the production of MMR by 48-h PHA-activated PBMC from 14 seronegative hemophiliacs highly exposed (HEH) to HIV-l infection was investigated.

These subjects belong to a cohort of 128 hemophiliacs with follow-up at the Hemophilia Centre of Milan. Each subject of the cohort was infused with an average amount of $3,300,000$ units of factor VIII and factor IX concentrates manufactured from huge pools of hepatitis $\mathrm{C}$ virus and HIV-1-contaminated plasma from paid U.S. plasmapheresis donors (Cutter; Hyland, Costa Mesa, CA; and Immune, Austria). Between 1980 and 1985 [before the availability of the blood test (11) and virus inactivation procedures], each patient received multiple infusions ranging from 3,000 to 990,000 units (median 105,000 units) of commercially available contaminated concentrates. Following the very first infusions with contaminated concentrates of all 128 patients, including the 14 highly exposed and still uninfected hemophiliacs $(\mathrm{HEH})$, were hepatitis $\mathrm{C}$ virus-positive patients as described $(12,13)$, but only three became infected by HIV, as determined by both serum Abs (ELISA and Western blot analysis) and genomic PCR. However, the number of HIV-1-infected subjects progressively increased with additional contaminated infusions and reached 59 in 1982, 84 in 1983, 103 in 1984, and 114 in 1985. Remarkably, the 14 HEH escaped HIV-1 infection despite receiving the multiple infusions (20-300) of 52,000-990,000 units (median 166,000 units) of contaminated concentrates.

In preliminary and sporadic experiments, the levels of chemokine production were markedly higher in PBMC collected from uninfected $\mathrm{HEH}$ than in those from miscellaneous seronegative control subjects. To confirm this result and to eliminate any bias due to 
cell culure llutuations (sec above). the production of MMR by activated fresh PBMC from If uninfected HEH and $1+$ seronegative controls was investigated at the same time and under identical culture conditions. A control group consisted of 14 seronegative volunter donors from the blood bank of Hopital Saint-Antoine (Paris). The mean and median levels of MMR production by $\mathrm{PBMC}$ from

Table 1. Production of $\mathrm{C}-\mathrm{C}$ chemokines in actived cells from HEH

A

\begin{tabular}{|c|c|c|c|c|}
\hline & MIP-1 $\alpha$ & 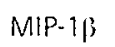 & RANTES & ${ }^{3} \mathrm{H}-\mathrm{T}$ \\
\hline Mean & 33.100 & 31.900 & 39.000 & 17,200 \\
\hline Median & 30,300 & 23,100 & 42,800 & 16.300 \\
\hline$n$ & 14 & 14 & 14 & 14 \\
\hline & \multicolumn{4}{|c|}{ Seronegative Controls } \\
\hline Mean & 15,000 & 16.500 & 24,700 & 19,000 \\
\hline Median & 11,400 & 14.200 & 19.000 & 17,500 \\
\hline . & 14 & 14 & 14 & 1 \\
\hline
\end{tabular}

Situdent's test $t=2.975 \quad t=2.430 \quad t=2.210 \quad$ Not significant $P<0.01 \quad P<0.05 \quad P<0.05$

$B$

N

$$
\text { HEH }
$$

Mean

Median

n

\begin{tabular}{|c|c|c|}
\hline \multirow[t]{2}{*}{$B$} & \multicolumn{2}{|l|}{ HEH } \\
\hline & MIP-1a & MIP-1B \\
\hline Mean & 38,800 & 41,300 \\
\hline tedian & 39,800 & 39,100 \\
\hline & 8 & 8 \\
\hline & \multicolumn{2}{|c|}{$\begin{array}{l}\text { Unexposed Mild } \\
\text { Hemophiliacs }\end{array}$} \\
\hline & MIP-1at & $M ! P-1 \beta$ \\
\hline
\end{tabular}

Mean

Median

n
18,300

12,000

17,900

8
10.500

8

\section{$\frac{\text { Seronegative Controls }}{\mathrm{MIP}-1 \mathrm{~K}} \mathrm{MIP-1 \beta}$}

16,800

16,600

15,900

$$
8
$$

14,800

Unexposed Severe

Hemophiliacs

\begin{tabular}{rr}
\hline MIP-1 & MIP-1 $\beta$ \\
16.900 & 16,300 \\
16,900 & 9.400 \\
8 & 8
\end{tabular}
the uninlected exposed hemo-philiacs were higher than those from the control. These differences were statistically significant (Student's $t$ test. $t=2.975$ with $\mathrm{P}=0.0063$ for MIPl $a, t=2.430$ with $\mathrm{P}=$ 0.0223 for MIP-1 $\beta$. and $t=$ 2.210 with $\mathrm{P}=0.0361$ for RANTES) (Table IA). It is important to note that the higher production found in the uninfected $\mathrm{HEH}$ did not appear to be the consequence of higher levels of activation/proliferation becaluse similar levels of cell replication were found in the two groups. The mean and median of ' $\mathrm{H}$-thymidine incorporation of 48 -h

PHA-activated PBMC were, respectively, 17.240 and $16.300 \mathrm{cpm}$ for the uninfected hemophiliacs and 19.080 and $17.450 \mathrm{cpm}$ for the control group.

In at second series of experiments also performed under identical culture conditions. chemokine production by PBMC from 8 of the $14 \mathrm{HEH}$ subjects randomly selected was compatred with that from PBMC of various seronegative controls. As shown in Table 1B, this experiment conlimed that MIP-l $\alpha$ production from HEH was over twotold higher than that from a new group of seronegative controls from Hôpital Saint Antoine, seronegatives with mild hemophilia who exhibit milder factor VIII defect and consequently did not need clotting concentrate infusion). or uninfected severe hemophiliacs who received only 
virus-inactivated or recombinant cloting factor concentrates. Levels of MIP-1P production in the different groups paralleled MIP-I a pattem (Table IB). The data of these two successive experiments (Table 1). which are represented statistically in a box plot (Fig. lc), clearly show that patients who resisted infection despite multiple exposures to HIV-1 expressed higher $\mathrm{C}-\mathrm{C}$ chemokine production than unexposed controls whether or not they were hemophiliacs.

Recent discoveries of natural mutations in the CCR5 coreceptor gene that affect both HIV-1 infection and progression 10 AIDS-defining illness (8. 14) prompted us to examine the coding genes for three chemokine receptors in these patients. A common 32-bp deficiency was discovered within the CCR5 locus in addition to several other point mutations at lower allele frequencies (8). The CCR5 $\triangle 32$ genotypes are illustrated in Fig. 2 , including $3+/ \triangle 32$ heterozygotes (PRET. RIUU, and GHGI). All other patients were homozygous for the common "normal" allele. A screen of the entire coding region using SSCP (15.16) did not reveal any other nucleotide sequence polymorphism among these patients. The other eight rare CCR5 alleles (<1\% in Caucasians) reported by Dean et al. ( 8 ) were not observed in these patients. A

Fig. 2. SSCP/HA analysis of CCR5 (formerly CKR5) among genotypes of 14 exposed uninfected individuals.

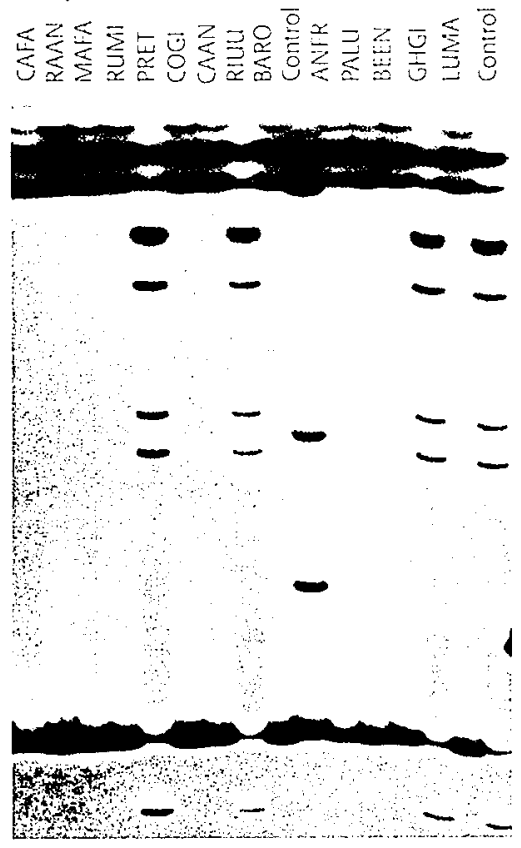

MIP-irs (ng/ml) MIP-1P (ng/ml) Rantes (ng/ml) $\begin{array}{ll}757 & 28333314145912 \cdot 2058174046\end{array}$ $606 \quad 21253919175718-1837106060$ $562122294848287044 \cdot 1841115754$ IFNa (IU/ml x10) 802.570404020 ND40 ND - 404054040

The central portion (347-753 bp) of CCR5 was amplified and run on anSSCP/HA gel. The gel resolves the single-stranded molecules (ss) and heteroduplexes (Het). and double-straded DNA is at the bottom of the gel. The heteroduplexes are formed in heterozygous individuals (PRET, RIUU, GHGl, and rt. control) by annealing of a strand of the wild-type allele with the complementary strand of the deletion allele. Lane 10 is a $+/ \mathrm{m}$ control with a point mutation; all other are homozygous CCRS $+/+$ similar heterozygous $\Delta 32$ deletion also was present in two individuals of the 12 tested controls. It is noteworthy that the three CCR $5+/ \Delta 32$ heterozygous hemophiliacs each produced high quantities of $C$ - $C$ che- 
mokines for MIP-l a equal to 33.49 , and $59 \times 10^{3} \mathrm{pg} / \mathrm{ml}$. Whether heterozygous $\triangle 32$ deletion determined the high level of chemokine secretion is presently unknown because elevated levels also were observed in multiply exposed but uninfected individuals homozygous for the normal CCR5 allele.

Primers were designed also to detect polymorphisms within $80 \%$ of the coding region of the CXCR4 locus. Polymorphism screens of several hundred individuals revealed a rare SSCP variant but no variation among the patients here screened. Finally, screens for mutations among CCR2B, a second coreceptor for macrophage-tropic HIV strains revealed a common variant that altered amino acid number 64 from valine to isoleucine. One patient (CAFA) was heterozygous for the CCR2B-1/2 genotype, and the rest were homozygous for the common " 1 " allele. The significance of this genotype on chemokine activity, HIV pathogenesis, or AIDS outcome presently is not understood.

To further confirm whether antiviral C-C chemokines or genetic heterozygote $\Delta 32$ abnormality play a role in HIV infection of immune cells, we infected activated PBMC from the three $\mathrm{HEH}$ with a $(+/ \triangle 32) \mathrm{CCR} 5$ heterozygotic abnomality, three $\mathrm{HEH}$ without the mutation, and three seronegative controls. PBMC from all of the individuals could be infected either by the laboratory NSI strain (Fig. 3) or by a primary isolate (AUD) of HIV1 as detected by p24 ELISA in culture SN (Fig. 3 b-d). However, when these PBMC were cultured in the presence of SN from 48-h PHA-activated autologous cells (which contain the $\beta$ chemokines) or with a mixture of recombinant MMR, viral infection was inhibited markedly (Fig. 3 a and b). The inhibition of viral infection was dose-dependent (Fig. 3c). Furthermore, when the MMR containing SN or MMR recombinant "cocktail" were preincubated with neutralizing anti-MMR Abs, their inhibitory effect was suppressed either markedly or totally (Fig. 3d).

The discovery of the anti-HIV-1 effect of some proinflammatory chemokines produced by immune cells (1) and the subsequent discovery of chemokine receptors as the second HIV-1 receptor $(4,5,17)$ initiated a series of studies to determine whether these anti-HIV1 cytokines or their receptor play a role during HIV-1 infection. Clarification of the specificity of the anti-HIV C-C chemokine effect has come from recent understanding of their mode of action. As indicated above, it recently has been shown that the HIV-1 second receptors are the chemokine receptors and belong to a family of seven transmembrane receptors $(5,18)$. Results in the original and subsequent reports $(6)$ on the magnitude of the antiviral effects by these chemokines already implied a dependency on the gp $120 \mathrm{~V} 3$ loop, believed to be involved in steps leading to the fusion of the virus and cell membranes after binding of the viral envelope to CD4. According to Wu et al. (19), a high affinity binding of gpl20 for CCR5, leading to membrane fusion and virus entry, involves the gp 120 V3 loop and follows HIV-1 attachment to CD4. The involvement of the V3 loop was established further by Trkola et al. (20), who showed that mAbs to the V3 loop inhibi- 
Fig. 3. HIV-1 infection of activated PBMC from HEH
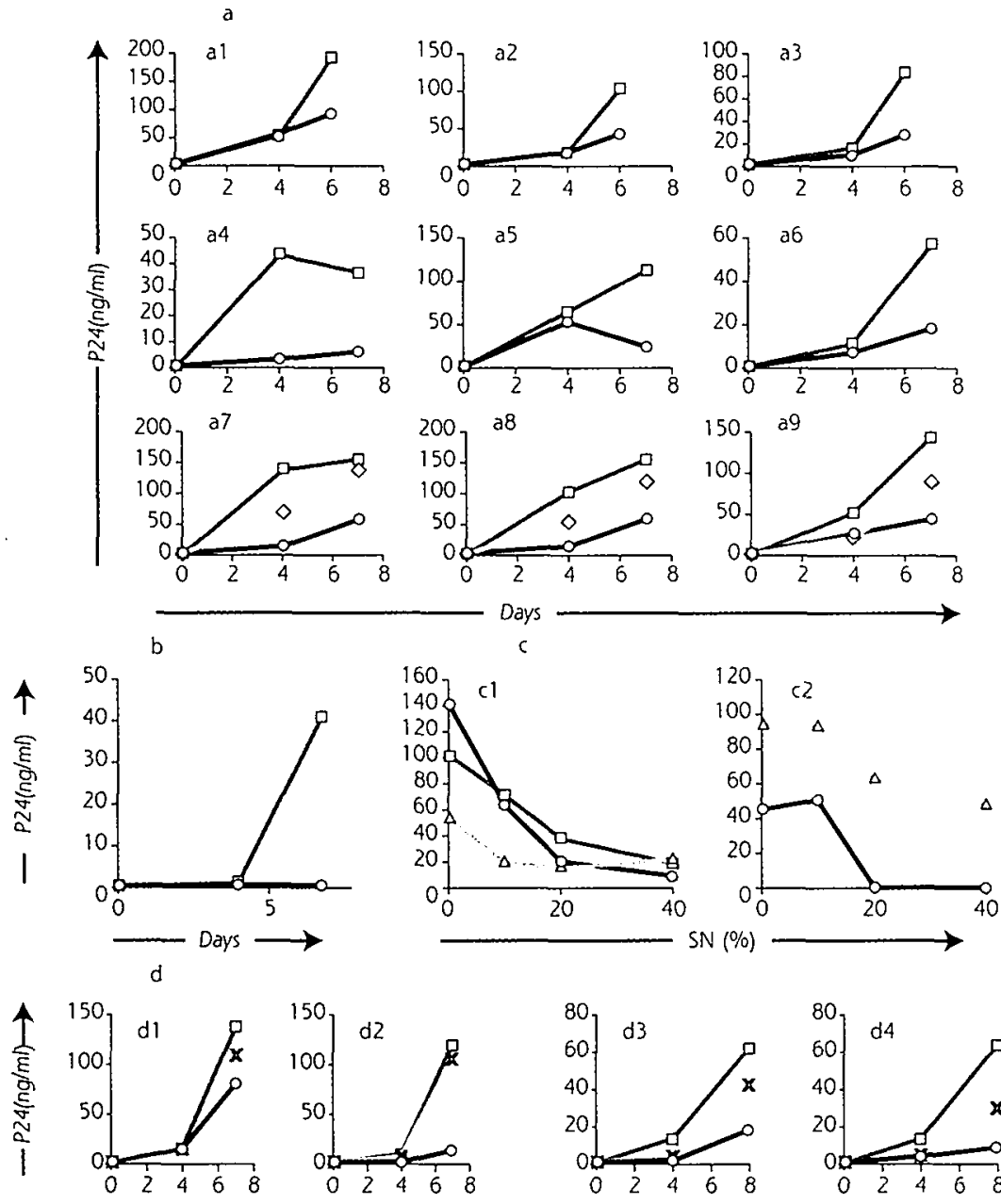

Days
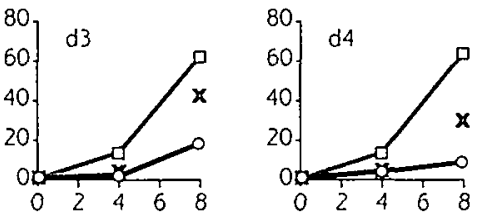

HIV-1 infection of PBMC in the presence of recombinant C-C chemokines (MMR) was assessed by P24 ELISA test. (a) Kinetics of HIV-linfection of seronegative cells by HIV-1 NSI, in the absence $(-\square)$ or presence $(-0-)$ of $40 \%$ of SN or of MMR ( $\diamond)$. The assay included cells from three control seronegative (a1-a3); $3 \mathrm{HEH}$ without $\triangle 32$ abnormality $(+1+)(a 4-a 6) ;$ and $3 \mathrm{HEH}$ with $\Delta 32$ abnormality $(\Delta 32 /+)(a 7-a 9)(a 7=R I U U ; ~ a 8=$ PRET; and a9 $=$ GHGIO).

(b) Kinetics of HIV-I infection by prymary isolate (AUD) in control cells in the absence (- - -) or presence $(-0-)$ of $S N$.

(c) Dose-dependent inhibition of HIV-1infection by autologous cell SN. This assay was performed for 7 days on cells from three HEH with $\triangle 32$ abnormality (-O-) RIUU; (- - -) PRET and $\left(\cdot \Delta_{--}\right)$GHGIO. Cells were infected with either HIV-1 296 (c1) or HIV-1 AUD (c2). (d) Effect of a mixture of neutralizing Abs to MMR on HIV-1 infection of PBMC from one HEH subject with $\Delta 32$ abnormality ( $\mathrm{d} l$ and $\mathrm{d} 2$ ) and one control donor (d3 and d4). Cells were infected with either HIV-1 Z96 (d1 and d3) or HIV-1 AUD (d2 and d4). Absence of SN (- - -); presence of SN (- - ); and presence of SN preincubated with neutralizing Abs ( $x$ ). 
ted the interaction of gP 120 with the CCR.5 second receptor, and by Cocchi et al. (6), who showed with HIV-I chimeras that the chemokine inhibitory effect was at least in part dependent on the V3 sequence.

Most hemophiliacs of the Milan cohort who repeattedly received infusions of contaminated factor. VIII and IX concentrates exhibited a natural resistance. though transient. to the inoculated HIV-I but not to hepatitis $\mathrm{C}$ virus. The resistance to HIV-1 initially observed varied from one individual to another because infection occurred for each subject of the cohory after a variable number $(6-2()))$ of infusions. Remarkably, the $\mathrm{HEH}$ who received over a median of 80 contaminated infusions $(20-300)$ remained uninfected to the present time. The immune cells of these seronegative HEH produced over twice the levels (mean and median) of MMR than other seronegative individuals whether hemophiliacs or not. athough there was no detectable difference in the activation (T cell proliferation) of HEH and control cells. Others have shown clevated production of these molecules by CD4+ T cells from two frequently sexually exposed but uninfected homosexual subjects (21).

Furthermore, because recent reports correlated protection with a variant form of chemokine receptor corresponding to mutation(s) or deletion(s) of the CCR5 structural gene $(8$. 22). this gene was analyzed in the uninfected HIV-1-exposed cohort. Genetic abnomalities were found in 3 of the 14 subjects (see Fig. 2). Of interest, these three individuals produced high levels of $\mathrm{C}-\mathrm{C}$ chemokines after cellular activation: $59.000,33,000$, and 49.000 $\mathrm{pg} / \mathrm{ml}$, respectively. Whether the chemokine response was related to the CCR5 genotype alteration or was coincidental remains to be shown. However, because five other subjects in the cohort without CCR.5 genetic abnormalities were also high producers of C-C chemokines, we can infer that other factors, either genetic. including other chemokine receptors $(3,5,17)$. or nongenetic. also may be involved in the increase of the chemokine secretion induced by immune cell activation. The protective direct effect of $\mathrm{C}$-C chemokine on HIV-I infection was verified by the last series of experiments that showed that $\mathrm{SN}$ from cultured PBMC oblained from the HEH cells (and known to contain the $\mathrm{C}$-C chemokines. MMR. or a cocktail of recombinant C-C chemokines) inhibited HIV-I infection. This inhibitory eflect wals dose-dependent and was abolished by anti-MMR neutralizing $\mathrm{Abs}$. The anti-HIV protective effect of C-C chemokine containing $\mathrm{SN}$ is also supported by experiments showing that in vitro PBMC from seronegative individuals become more resistant to HIV-I infection when these cells release large quantities of $\mathrm{C}-\mathrm{C}$ chemokines. i.e., al the initiation of activation rather than when they secrete basal levels, i.e., 3-6 days after activation. In a representative experiment using cells from a $\mathrm{HEH}$ subject (PRET). PBMC infection performed at the initiation of activation (with MIP- $1 \alpha$ release $=47$ $\mathrm{ng} / \mathrm{ml}$ ) was 11 -fold less effective than when viral treatment followed activation (with MIP-la release $=1.1 \mathrm{ng} / \mathrm{ml}$ ).

The clinical data related to natural resistance to HIV contamination. including those repor- 
ted in this study, corroborate the experimental results. It is well known that there is a small percentage of persons who remain uninfected in populations at high risk of HIV intection. This includes hemophiliacs who received contaminated blood products and individuals exposed to "unsafe" sexual activity with HIV-1-positive partners (23). Resistance to infection was correlated in exposed but uninfected Gambians with a higher specific activity of cytotoxic T lymphocyles (CTL) (23). whereas in the present study resistance in uninfected hemophiliacs was correlated with a higher production of $\mathrm{MMR}$. It seems that C-C chemokine secretion and differentiation of CTL are two effector processes of the same cellular arm of the immune reaction. the former acting as early as $12 \pm$ $6 \mathrm{~h}$ after initiation of the immune activation and before cell proliferation (Fig. 1) and the latter being effective 5-8 days after differentiation of effective anti-HIV-1 CTL from naive or memory precursor cells through a series of cell divisions. Confirmation of this assertion came from a set of experiments carried out on PBMC from five subjects of the HEH cohort and five nomal individuals. These cells, and not cells from seronegative controls, exhibited a memory cytotoxic activity directed against HIV-1 gpl60 antigens, which was reactivated by mixed lymphocyte cultures carried out in the presence of effector PBMC and irradiated autologous blasts infected by HIV-1. CTL activity was measured by lysis of target autologous B cell lines infected with gp 160 recombinant vaccinia and was HLA-restricted and dependent on the effector-to-target cell ratio in the range of 40:1-0.3:1 (not shown).

Exposure to HIV-1 may or may not result in infection. The outcome depends on viral (number of infectious particles; viral strain) but also host factors, including the cellular immune response to the infection. In this study, we showed that anti-HIV- I chemokines, released as an initial effector component of the cellular response, play a major role in determining resistance to HIV-I infection, at least in vitro (Fig. 3). We infer from this that resistance is due to their greater capacity to develop a stronger cellular immune response, including the early release of C-C chemokines. The few resistant individuals could be defined as "high responders" of the cellular arm of the immune response by analogy to the known high responder mice producing elevated levels of Abs in response to antigen stimulation (humoral arm) as described by Biozzi et al. (24).

To combat HIV-1, the host cellular immune defense possesses two specific weapons both resulting from the immune cell response to activation. In the initial line of defense, the $\mathrm{C}$ $C$ chemokines are produced very early, and in the second line of defense, CTL are strongly effective after several days of differentiation of naïve or memory precursor cells. In uninfected individuals, these anti-HIV-I effector components of the cellular response can prevent infection. particularly in the few "high cellular responders," such as the HEH of the Milan cohort. These effectors may be capable of containing HIV-1 until immune incompetence, triggered by HIV-1 through escape mutants and resultant higher produc- 
tion of pathogenic viral proteins, leads to uncontrolled viral growth and immune suppression (25). The escape mutants may arise by the development of SI variants from the earlier NSI variants, the chief virus type transmitted from person-to-person (26). The NSI variants are $\beta$ chemokine-sensitive, whereas the emerging SI variants are not sensitive (27). Increase of acute infection processes with highly replicating viruses (28) resulting from uncontrolled viral growth is a source of HIV-1 proteins, including gp 120 and extracellular Tat (29). These pathogenic proteins (30) should contribute to the dramatic immune suppression of uninfected T cells characterizing AIDS.

\section{References}

1. Cocchi F, DeVico AL, Garzino-Demo A, Arya SK. Gallo RC \& Lusso P. (1995) Science 270. $1811-1815$.

2. Walker CM, Moody DJ, Stites DP \& Levy JA (1986) Science 234, 503-506.

3. Feng Y, Broder CC, Kennedy PE \& Berger EA (1996) Science 272,872-877.

4. Alkhatib G. Combadiere C, Broder CC, Feng Y, Kennedy PE, Murphy PM \& Berger EA. (1996) Science 272, 1955-1958.

5. Deng H, Liu R, Ellmeier W, Choe S, Unutmaz D, Burkhart M, Di Marzio P, Marmom S, Sutton RE, Hill CM, et al. (1996) Nature (London) 381, 661-606.

6. Cocchi F, DeVico AL, Garzino-Demo A, Cara A, Gallo RC \& Lusso P(1996) Nat. Med. 2. 1244-1247.

7. Samson M, Libert F, Doranz BJ, Rucker J, Liesnard C. Farber CM, Saragosti S, Lapoumeroulie C, Cognaux J, Forceille C, et al. (1996) Nature (London) 382, 722-725.

8. Dean M, Carrington M, Winkler C, Huttley GA, Smith MW, Allikmets R, Goedert JJ, Buchbinder SP, Vitting-hoff E, Gomperts E, et al. (1996) Science 273. 1856-1862.

9. Biti R, French R, Young J, Bennetts B, Stewart G. \& Liang T. (1996) Science 272.1955-1958.

10. Ritter LM, Bryans M. Abdo O, Sharma V \& Wilkie NM. (1995) Mol. Cell Biol. 15, 3/l0-3/l8.
11. Sarngadharan MG, Popovic M, Bruch L. Schupbach J \& Gallo RC. (1984) Science 224. 506-508.

12. Fletcher ML, Trowell JM, Craske J, Pavier K \& Rizza CR. (1983) Br: Med.J. 287, 1754-1757.

13. Kernoff $P B$, Lee $C A$, Karayiannis $P$ \& Thomas HC. (1985) Br.J. Haematol. 60 . 469-479.

14. Huang Y, Paxton WA, Wolinsky SM, Neumann AU, Zhang L, He T, Kang S, Ceradini D, Jin Z, Yazdanbakhsh K, et al. (1996) Nat. Med. 2, 1240-1243.

15. White MB, Carvalho M, Derse D, O'Brien SJ \& Dean M. (1992) Genomics 12, 301-306.

16. Ravnik-Glavac M, Glavac D \& Dean M. (1994) Hum. Mol. Genet. 3, 801-807.

17. Choc H, Farzan M, Sun Y, Sullivan N, Rollins B, Ponath PD, Wu L, Mackay CR, LaRosa G. Newman W, et al. (1996) Cell 85, 1/35-1/48. 18. Dragic T, Litwin V, Allaway GP, Martin SR, Huang Y, Nagashima KA, Cayanan C, Maddon PJ, Koup RA, Moore JP. et al. (1996) Nature (London) 38I, 667-673.

19. Wu L, Gerard NP, Wyatt R, Choe H. Parolin C, Ruffing N, Borsetti A, Cardoso A A. Desjardin E. Newman W, cl al. (1996) Nature (London) 384 , 179-183.

20. Trkola A, Draagic T, Arthos J, Binley JM. Olson WC, Allaway GP, Cheng-Mayer C, 
Robinson J. Maddon PJ \& Moore JP (1996)

Nanure (London) 384, 184-187.

21. Paxton WA, Martin SR, Tse D, O'Briend TR, Skumick J, VanDevanter NL. Padian N. Braun JF, Kotler DP. Wolinsky SM, et al. (1996) Nat. Mod. $2,4 / 2-4 / 7$.

22. Liu R. Paxion WA, Choe S. Ceradini D, Martin SR, Horuk R. MacDonald ME, Stohlman H. Koup RA. \& Landau, N. (1996) Cell 86. $367-377$.

23. Rowland-Jones SL \& McMichacl A (1995) Curr: Opin. Immunol. 7, 448-455.

24. Biozzi G. Stiffel C, Mouton D, Bouthillier $Y$ \& Decreuse-fond C. (1972) J. E.xp. Med. 135. $1071-1094$.

25. Goulder PJ, Phillips RE, Colbert RA,
McAdam S, Ogg S, Nowak MA, Giangrande P, Luzzi G, Morgan B, Edwards A, et al. (1997) Nat. Med. 3, 2/2-2/7.

26. Balotta $C$, Vigano A, Riva C. Colombo MC, Salvaggio A, De Pasquale MP, Crupi L, Papagno L. Galli M, Moroni M, et al. (1996) AIDS Re's. Hum. Retrovinuses 12, 1247-1253.

27. Jansson M, Popovic M. Karlsson A, Cocchi F, Rossi P, Albert J \& Wigzell H (1996) Proc. Natl. Acad. Sci. USA 93, 15382-15387.

28. Coffin JM. (1995) Science 267. 483-489.

29. Ensoli B, Gendelman R. Markham P. Fiorelli V, Colombini S. Raffeld M, Cafaro A. Chang HK, Brady JN \& Gallo RC. (1994) Natwe (London) $371.674-680$.

30. Zagury, D. (1997) Nat. Med. 3. 156-157. 


\section{Chapter 4}

\section{Non-lipid enveloped viruses: transmission by factor concentrates}

- Transmission of parvovirus B19 by coagulation factor concentrates exposed to $100^{\circ} \mathrm{C}$ heat after lyophilization.

Transfusion 37: 517-522, 1997 


\section{Transmission of parvovirus B19 by coagulation factor concentrates exposed to $100^{\circ} \mathrm{C}$ heat after lyophilization}

E. Santagostino, P.M. Mannucci, A. Gringeri, A. Azzi. M. Morfini,

R. Musso, R. Santoro, M. Schiavoni.

Angelo Bianchi Bonomi Hemophilia and Thrombosis Center, IRCCS Maggiore Hospital and University of Milan, and The Study Group of the Association of Italian Hemophilia Center Directors, Italy.

Transfusion 37: 517-522, 1997

Grant support: This study was supported in part by instimutional grants from the IRCCS Maggiore Hospital, Milan, Italy 


\begin{abstract}
Background: Double-inactivation by solvent/detergent plus terminal heating at $100^{\circ} \mathrm{C}$ for $30 \mathrm{~min}$. has been adopted to improve viral safety of FVIII and FIX concentrates, particularly with respect to non-lipid-enveloped viruses. Aim of this study was to evaluate the safety of concentrates exposed to these virucidal methods.

Study Design and Methods: Twenty-six previously untreated hemophiliacs, 19 with FVIII and 7 with FIX deficiency, were investigated in a prospective multicenter study over a 12-month follow-up period using serological and virological markers for lipid- and non-lipid-enveloped viruses (HIV-1 and HIV-2, HBV, HCV, HAV and B 19 parvovirus antibodies and B 19 DNA). Overall , 270,000 U of FVIII and 102,000 U of FIX concentrate were administered during the study period.

Results: None of the 26 patients seroconverted for HIV or HCV. HBV markers remained negative in the 10 unvaccinated hemophiliacs. No HAV seroconversion occurred among 17 susceptible patients. B 19 seroconversion (IgM) and B 19 viremia were observed within 2 weeks from the first concentrate infusion in $8 / 15$ susceptible patients, $5 / 11$ treated with FVIII and $3 / 4$ with FIX concentrate.

Conclusion: This prospective study indicates that very high temperatures applied to lyophilized concentrates appear to prevent HAV transmission to hemophiliacs. However, B 19 parvovirus still contaminates concentrates despite the use of this robust virucidal method.
\end{abstract}

\title{
Introduction
}

The risk of transmission of blood-borne viral infections by plasma-derived factor VIII (FVIII) and factor IX (FIX) concentrates employed for hemophilia care is currently small'. The adoption of virucidal methods based upon heating the lyophilized concentrates at $80^{\circ} \mathrm{C}$, vapour-heating, pasteurization and chemical treatment with solvent/detergent has virtually assured safety for the human immunodeficiency virus (HIV) . $^{2.3}$ and greatly improved that for the hepatitis $\mathrm{B}$ and $\mathrm{C}$ viruses ( $\mathrm{HBV}$ and $\mathrm{HCV})^{4.7}$. Even though a few cases of $\mathrm{HCV}$ infection have occasionally occurred in patients treated with some of these virallyinactivated concentrates, (for review, see Mannuccil), none of them has been related to the use of concentrates inactivated with solvent/detergent, a virucidal method that is very efficacious against HCV. However, the outbreaks of hepatitis A that occurred in European patients treated exclusively with solvent/detergent FVIII concentrates ${ }^{\mathrm{s} .9}$ and the recent report from the USA of hepatitis A cases associated with similarly treated FVIII and FIX concentrates $^{10}$ have emphasized that complete viral safety is still far from being achieved with this virucidal method that, highly efficient in removing lipid-enveloped viruses, does not inactivate viruses with no lipid envelope, such as the hepatitis A virus (HAV) ${ }^{7}$. Also the B19 parvovinus, another "naked" and highly thermoresistant virus, is still transmitted 
by solvent/detergent and other virucidal methods adopted for concentrates currently used in the treatment of hemophiliar ${ }^{7.11 .12}$.

Evidence of concentrate-transmitted HAV and parvovirus B 19 infections indicates that there is a possibility of parenteral transmission of viruses that give short term viremia and that until recently were thought to be exceptionally transmitted by this route. For these reasons, concentrate manufacturers are attempting to increase viral safety using new approaches, such as heating the products at temperatures even higher than $80^{\circ} \mathrm{C}$, ultrafiltration through membranes with very small retaining pores and with the combination of different virucidal methods.

To achieve this goal, an Italian manufacturer has chosen to use a method based upon the addition of a step of terminal heating at $100^{\circ} \mathrm{C}$ for $30 \mathrm{~min}$. to solvent/detergent treated lyophilized concentrates. The virucidal efficacy of this method was first evaluated by spiking the concentrates in vitro with enveloped and non-enveloped model viruses and demonstrating a satisfactory degree of removal and inactivation ${ }^{13}$. Nevertheless, stringent evidence for viral safety can only be provided by prospective clinical studies ${ }^{14}$. Patients with hemophilia not previously exposed to any blood product and treated only with the study concentrate represent the most suitable clinical model for such studies, because they are at very high risk of developing post-transfusion viral infections. With the aim of evaluating the safety of FVIII and FIX concentrates double-inactivated using in combination the solvent/detergent method and terminal heating at $100^{\circ} \mathrm{C}$, a prospective multicenter study was carried out in previously untreated hemophiliacs. In these patients multiple serological and virological markers for blood-borne infections were used and a strict surveillance with respect to inhibitor development was implemented.

\section{Materials and methods}

Concentrates. The FVIII and FIX study products were commercial concentrates (Emoclot D.I. and Aimafix D.I., AIMA Derivati SpA, Bologna, Italy) purified from plasma by ion-exchange chromatography. No albumin was added. Final specific activities of the lots employed in this study were $95 \mathrm{IU}$ of FVIII/mg of total protein and $65 \mathrm{IU}$ of FIX/mg. The concentrates were virally-inactivated combining the solvent/detergent (TNBP/Tween 80) method with terminal heating of the lyophilized product at $100^{\circ} \mathrm{C}$ for 30 min. ${ }^{15}$. Twenty-five lots of FVIII concentrate and 15 lots of FIX concentrate were administered to patients between 1992 and 1996. Each lot was manufactured from plasma pooled from approximately 10,000 plasmapheresis donations from paid donors from the United States and unpaid donors from Italy. All plasma units were negative for hepatitis B surface antigen, anti-HCV and anti-HIV and had alanine aminotransferase (ALT) levels less than twice the upper normal limit.

Protocol. Patients eligible for this prospective study were selected according to the 
revised criteria recommended by the Scientific and Standardization Committee of the International Society for Thrombosis and Haemostasis for the evaluation of the viral salety of coagulation factor concentrates ${ }^{14}$. Therefore, they had no previous exposure to blood or blood products, normal baseline levels of ALT, no history or current evidence of liver disease and no serum markers for HIV, HCV and HBV infection (except for markers secondary to HBV and HAV vaccinations). Patients included in the trial received exclusively the study product during the scheduled 12-month follow-up. They underwent serological examinations to assess the virological status at study entry and after the first concentrate infusion at time points scheduled according to the known timing of seroconversion for blood-borne viral infections. Serological markers for hepatitis viruses (HBV. HCV and HAV) were determined every 4 weeks up to week 16 after the first infusion. HIV-1 and -2 antibodies were determined at week 0,8 and 16. These virological markers were determined again at weeks 26,38 and 52. Serum ALT levels were measured on baseline and after the first infusion, at 2-week intervals for 16 weeks and then at weeks 20,26. 38 and 52. B19 parvovirus antibodies and B19 DNA were determined at weeks $0,1,2,4$ and 12. These time intervals were chosen because viremia and anti-B $19 \mathrm{IgM}$ develop transiently and usually within 1-2 weeks of exposure to the virus, whereas anti-B 19 IgG develops later and persist longer ${ }^{11.2}$. Hemoglobin levels were monitored at the same time points, to detect any transient red cell hypoplasia that may be induced by $\mathrm{B} 19$ parvovirus. Inhibitor surveillance was conducted in all pattients performing the Bethesda assay at least every 12 weeks after the first infusion.

Patients. Eight Italian hemophilia centers enrolled 26 previously untreated patients who had accepted to be infused for one year exclusively with the study concentrate, had signed an informed consent and needed to be treated for the first time between October 1992 and February 1996. Demographic data and clinical characteristics of the patients are shown in Table 1. All patients were monitored for 12 months but two (patients 5 and 6) have not yet completed the scheduled follow-up period. with their latest evaluation performed 6 and 5 months after the first treatment. All patients (median age. 10.2 years: range 0.1-56), except one who had von Willebrand disease, had hemophilia (18 hemophilia A and 7 hemophilia B) with different severity degrees of the defect (Table 1). Patients with mild hemophilia A or von Willebrand disease were known to be unresponsive or poorly responsive to desmopressin. All 26 patients met the enrollment criteria and were therefore negative for HIV and HCV serum antibodies and markers for $\mathrm{HBV}$ infection. Among 26 patients, 16 had been previously vaccinated against HBV and 4 against HAV.

Assays. Alanine aminotransferase, hemoglobin and viral markers were determined with the methods currently adopted by each local laboratory, except for B 19 parvovirus antibody and DNA that were centrally tested in Florence (A.A.). HBV markers, HIV-1 
Table 1. Demographic, clinical and serological characteristics for 26 previously untreated patients given double-inactivated FVIII or FIX concentrate.

\begin{tabular}{|c|c|c|c|c|c|c|c|c|c|}
\hline \multirow{2}{*}{$\begin{array}{l}\text { Patient } \\
\text { code }\end{array}$} & \multirow{2}{*}{$\begin{array}{l}\text { Age/Sex } \\
\text { (years) }\end{array}$} & \multirow{2}{*}{$\begin{array}{l}\text { FVIII / FIX } \\
\text { level (\%) }\end{array}$} & \multirow[t]{2}{*}{ Diagnosis } & \multirow{2}{*}{$\begin{array}{l}\text { Follow-up } \\
\text { period (mth) }\end{array}$} & \multicolumn{5}{|c|}{ Susceptibility to Viral Infections* } \\
\hline & & & & & HIV & $\mathrm{HCV}$ & HBV & HAV & B19 \\
\hline 01 & $56 / M$ & 12 & Hem. A & 12 & Yes & Yes & Yes & No & No \\
\hline 02 & $4.3 / M$ & 5 & Hem. A & 12 & Yes & Yes & Yes & Yes & No \\
\hline 03 & $23 / \mathrm{M}$ & 23 & Hem. A & 12 & Yes & Yes & Vac. & Yes & No \\
\hline 04 & $2.5 / \mathrm{M}$ & 1.8 & Hem. B & 12 & Yes & Yes & Vac. & Vac. & Yes \\
\hline 05 & $1.1 / \mathrm{M}$ & $<1$ & Hem. A & 6 & Yes & Yes & Vac. & Vac. & Yes \\
\hline 06 & $0.8 / M$ & 1.7 & Hem. A & 5 & Yes & Yes & Vac. & Vac. & Yes \\
\hline 07 & $2.1 / \mathrm{M}$ & 6 & Hem. A & 12 & Yes & Yes & Vac. & Yes & Yes \\
\hline 08 & $6.4 / M$ & 10 & Hem. B & 12 & Yes & Yes & Vac. & Yes & Yes \\
\hline 09 & $0.9 / M$ & 26 & Hem. A & 12 & Yes & Yes & Vac. & No & Yes \\
\hline 10 & $4 / F$ & 40 & VWD & 12 & Yes & Yes & Yes & Yes & Yes \\
\hline 11 & $18 / M$ & 3 & Hem. A & 12 & Yes & Yes & Yes & Yes & Yes \\
\hline 12 & $14 / M$ & 4 & Hem. A & 12 & Yes & Yes & Yes & Yes & Yes \\
\hline 13 & $30 / M$ & 4 & Hem. A & 12 & Yes & Yes & Yes & Yes & No \\
\hline 14 & $25 / M$ & 3 & Hem. A & 12 & Yes & Yes & Yes & Yes & No \\
\hline 15 & $35 / M$ & 3 & Hem. A & 12 & Yes & Yes & Yes & Yes & No \\
\hline 16 & $0.9 / \mathrm{M}$ & 2 & Hem. A & 12 & Yes & Yes & Vac. & Yes & Yes \\
\hline 17 & $49 / M$ & 27 & Hem. A & 12 & Yes & Yes & Yes & No & Yes \\
\hline 18 & $1.7 / \mathrm{M}$ & $<1$ & Hem. A & 12 & Yes & Yes & Vac. & Yes & Yes \\
\hline 19 & $2.8 / \mathrm{M}$ & 2 & Hem. A & 12 & Yes & Yes & Vac. & Yes & Yes \\
\hline 20 & $32 / M$ & 6 & Hem. A & 12 & Yes & Yes & Vac. & No & Yes \\
\hline 21 & $35 / M$ & 7 & Hem. B & 12 & Yes & Yes & Vac. & No & No \\
\hline 22 & $19 / \mathrm{F}$ & 42 & Hem. A & 12 & Yes & Yes & Yes & Yes & Yes \\
\hline 23 & $5.3 / \mathrm{M}$ & 11 & Hem. B & 12 & Yes & Yes & Vac. & Yes & No \\
\hline 24 & $15 / M$ & 24 & Hem. B & 12 & Yes & Yes & Vac. & Yes & Yes \\
\hline 25 & $3.8 / M$ & 2 & Hem. B & 12 & Yes & Yes & Vac. & Vac. & Yes \\
\hline 26 & $0.1 / \mathrm{M}$ & $<1$ & Hem. B & 12 & Yes & Yes & Vac. & Yes & Yes \\
\hline
\end{tabular}

Hem: hemophilia, vWD: von Willebrand disease

* Yes: absence of markers for past or active infection. No: $\lg G$ positivity due to past contact with the virus; Vac: IgG positivity due to vaccination

and HIV-2 antibodies and anti-HAV IgM and IgG were tested by enzyme immunoassays. HCV antibodies were tested by second-generation enzyme immunoassays. B19 parvovirus antibodies were tested by $\operatorname{IgM}$ - and $\mathrm{IgG}$ - capture radioimmunoassay" and B19 DNA by nested PCR1². FVIII and FIX inhibitors were locally measured by the Bethesda assay. 


\section{Results}

Patient Characteristics. Baseline coagulation and serological data for each of the 26 study patients are reported in Table 1 . All patients were evaluable for HIV and $\mathrm{HCV}$ infections, whereas 16 were excluded from analysis for HBV infection because they had been vaccinated. Of the 26 patients, 17 were evaluable for HAV infection, with 5 positive for anti-HAV IgG as a consequence of past contact with the virus and 4 vaccinated. Serological evaluation for parvovirus B 19 infection carried out at study entry detected anti-B $19 \lg G$ positivity in 8 patients. Of the remaining 18 evaluable patients, 3 (patients 9,11 and 26) were excluded from the final analysis for B 19 infection because crucial serum samples were not obtained during the first two critical weeks after the first concentrate infusion.

Overall, 212,000 U of FVIII and FIX concentrates were administered during the study period to the 26 patients in the trial. The total amount of FVIII concentrate received by 19 patients was $270,000 \mathrm{U}$ from 25 lots, injected in 121 different infusions (median FVIII usage 3,000 U/patient; range 500-168,500 U) and the median number of FVIII lots administered to each patient was 1 (range 1-6). The 7 patients with hemophilia B were given 102,000 U of FIX concentrate from 15 lots in 55 infusions (median FIX usage 6,500 U/patient; range 2,500-52,500 U) and the median number of lots received by each of these patients was 2 (range 1-6).

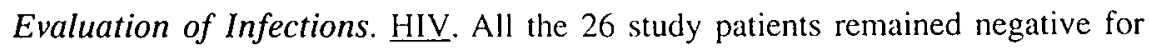
antibodies to HIV-1 and -2 during the entire 12-month follow-up period. For patients 5 and 6 , who did not fully complete the follow-up period, the most recent negative result was obtained 6 and 5 months after the first infusion.

HBV. Ten patients, all treated with FVIII concentrate, were analyzable for HBV infection and none developed serological markers over the 12-month study period.

$\mathrm{HCV}$. None of the 26 patients became anti-HCV positive. All patients were monitored for 12 months, except two (see above) who have not completed the study period.

HAV. No seroconversion was observed during the follow-up period among the 17 patients ( 13 treated with FVIII and 4 with FIX) evaluable for HAV transmission.

ALT. Normal levels of ALT were maintained throughout the study in all patients.

Parvovirus B19. The evaluation was carried out in 15 susceptible patients monitored for 12 weeks following the first exposure to the concentrate (FVIII in 11 and FIX in 4). B19 seroconversion and viremia were observed in $8 / 15$ patients, $5 / 11$ treated with FVIII concentrate and $3 / 4$ treated with FIX concentrate. The analysis of sequential serum samples from these patients revealed the development of anti-B $19 \operatorname{IgM}$ at weeks 1 or 2 after the first infusion and the presence of B 19 DNA at week 1 (Table 2). Table 2 shows the details of the replacement therapy received by the 8 seroconverters during the first week of the study, before the occurrence of B 19 viremia. The amount 
of FVIII administered to each of the 5 patients during this period ranged from 500 to 15,000 $\mathrm{U}$ and derived from 7 different lots. Two of these FVIII lots were also infused in 2 of the 6 susceptible patients who showed no evidence of B 19 infection during the follow-up period (patient 12 received 2,000 U of FVIII concentrate from lot $f$ and patient $173,500 \mathrm{U}$ from lot d). The amount of FIX given during for the first week to the 3 seroconverters with hemophilia $B$ ranged between 3,500 and $19,500 \mathrm{U}$ and derived from 8 different lots, one (lot $n$ ) was given to both subjects 24 and 25 . None of these FIX lots was infused to the remaining susceptible patient who did not seroconvert for B 19 parvovirus during the study.

All seroconverters had a transient drop in hemoglo-

Table 2. Therapy received during the first week of the study by the 8 patients before there was seroconversion or detectable B19 DNA

\begin{tabular}{|c|c|c|c|c|c|}
\hline $\begin{array}{l}\text { Patient } \\
\text { code }\end{array}$ & $\begin{array}{l}\text { FVIII dose } \\
\text { (IU) }\end{array}$ & $\begin{array}{l}\text { FIX dose } \\
\text { (IIU) }\end{array}$ & Lots & $\begin{array}{l}\lg M \\
\text { anti-B19*}\end{array}$ & $\begin{array}{l}\text { B19 } \\
\text { DNA }^{\wedge}\end{array}$ \\
\hline 05 & 3,000 & --- & $a, b$ & Pos & Pos \\
\hline 08 &.-- & 4,000 & $c$ & Pos & Pos \\
\hline 16 & 500 & 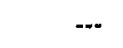 & d & Pos & Pos \\
\hline 18 & 1,500 & --- & e & Pos & Pos \\
\hline 19 & 2,000 & -.- & $f$ & Pos & Pos \\
\hline 22 & 15,000 & .-- & $g, h$ & Pos & Pos \\
\hline 24 & --. & 19.500 & $1, m, n, o$ & Pos & Pos \\
\hline 25 & -.- & 3,500 & $n, p, q$ & Pos & Pos \\
\hline
\end{tabular}

*Seroconversion was observed 1 to 2 weeks after the first infusion of concentrate. - B19DNA was detectable 1 week after the first exposure to the concentrate. bin from pre-infusion levels, ranging between 0.5 and $2.2 \mathrm{gr} / \mathrm{dl}$ (median $1.1 \mathrm{gr} / \mathrm{dl}$ ) and occurring within 2 weeks. This drop could not be explained by concomitant bleeding and hemoglobin levels returned spontaneously to baseline within one month. By that time, anti-B19 $1 \mathrm{gG}$ were detectable in all patients and in 4 of them (patients 5, 22, 24 and 25) B19 DNA was still detectable after 12 weeks. No other clinical manifestation of parvovirus infection was observed in the 8 seroconverters during the study.

Inhibitor Surveillance. During the 12-month follow-up period, the 26 previously untreated patients were exposed to the study concentrate during 1-19 infusion days (median 4). No inhibitor developed in the 21 hemophiliacs with mild or moderate coagulation factor defects ( 16 with FVIII levels $\geq 2 \%$ and 5 with FIX $\geq 2 \%$ ). Among the remaining 5 patients with severe defects, 3 with hemophilia $A$ (patients 5,6 and 18 treated for 16, 2 and 4 exposure days, respectively) and 2 with hemophilia $B$ (patients 4 and 26 , both treated for 6 exposure days), an inhibitor was detected only in patient 5 two months after enrollment. At that time, anti-FVIII antibody was $6 \mathrm{BU} / \mathrm{ml}$ and had developed after 16 exposure days accumulated during 2 treatment courses (overall, 8,500 U of FVIll concentrate from 3 lots). Since the same inhibitor titer was measured at one month after no additional FVIII infusion was given, immunotoleran- 
ce was started with a daily dose of $200 \mathrm{U} / \mathrm{Kg}$. The latest inhibitor, measured 2 months after starting immunotolerance (total FVIII amount administered during immunotolerance $160,000 \mathrm{U}$ ) was $1 \mathrm{BU} / \mathrm{ml}$.

\section{Discussion}

Recently, concentrate manufacturers have adopted with increasing frequency combined virucidal inactivation procedures to improve viral safety of plasma-derived products, particularly with respect to viruses without lipid envelopes. This prospective trial conducted in previously untreated patients infused exclusively with FVIII and FIX concentrates double-inactivated with solvent-detergent and terminal heating at $100^{\circ} \mathrm{C}$ indicates that HIV, HBV and HCV are not transmitted.

Serological surveillance of HAV infection, carried out for the first time in a prospective safety study albeit in a limited number of susceptible patients, indicates that heating at $100^{\circ} \mathrm{C}$ for $30 \mathrm{~min}$. seems to prevent HAV transmission. However, concentrate contamination by $\mathrm{B} 19$ parvovirus is indicated by the observation of B $19 \mathrm{IgM}$ seroconversion in 8 of the 15 susceptible hemophiliacs enrolled in this trial. All seroconversions occurred in close time relationship with the first concentrate infusion (after one to two weeks) and B19 DNA was detected in all cases one week after the first exposure to the concentrate. A transient drop in hemoglobin levels, although slight and clinically irrelevant, was observed in all seroconverters 2 weeks after the infusion, with a recovery within one month. The observed drop in hemoglobin is likely to be related to the inhibitory effect of B 19 parvovirus on erythroid precursors. Apart from the drop in hemoglobin the 8 seroconverters had no clinical syndrome related to parvovirus infection. This finding is consistent with the knowledge that parvovirus infection has minor clinical consequences in immunocompetent individuals and may pose a threat only to immunocompromised hosts who are at high risk to develop chronic infection and severe aplastic anemia because of their decreased ability to clear the virus ${ }^{16}$.

It has been surmised that the development of PCR positivity and IgM antibody does not implicate the occurrence of an active B 19 infection but could only be the expression of the transmission of viral particles still immunogenic but not infectious ${ }^{17}$. B19 infection can be unequivocally demonstrated only by PCR analysis of the DNA extracted from bone marrow erythroid precursors, an unfeasible approach in the setting of this clinical trial. On the other hand, the observed persistence of serum B 19 DNA in 4 seroconverters 12 weeks after the first concentrate infusion despite no further concentrate infusion is more compatible with an active infection rather than with the presence of inactivated B 19 particles inducing immunization. Community - acquired infection with parvovirus B 19 transmitted through the respiratory tract are common in childhood. A study design involving a control group of hemophiliacs not treated with 
concentrates would have been useful to minimize the possible role of community acquired-infections. However, previously untreated hemophiliacs eligible for safety studies and susceptible to B 19 infection are rare and comparable untreated patients necessary to constitute an adequate control group are similarly rare.

The results obtained from the inhibitor survey carried out during the trial are very limited and do not provide definite information about the immunogenicity of $100^{\circ} \mathrm{C}$ heated products and to exclude that this robust virucidal method engenders neoantigen formation. The majority of patients in the study were moderate and mild hemophiliacs who, although previously untreated, are not at very high risk for developing inhibitors. The occurrence of an inhibitor in one of three enrolled patients with severe hemophilia A remains anecdotal for the small number of evaluable patients. Moreover, each study patient received replacement treatment during a limited number of exposure days, perhaps insufficient to elicit the antibody production and hence to fully assess the risk of inhibitor formation. On the other hand, the large scale clinical use of these FVIII and FIX concentrates since their introduction in Italy in 1992 (more than 300 million units) has not induced any inhibitor outbreak among hemophiliacs previously exposed to other sources of FVIII and FIX. This observation contrasts with at least two epidemics of fresh inhibitors which occurred in European hemophiliacs switched to concentrates different from those previously used in terms of virucidal and fractionation methods $^{1 \times-20}$.

This study demonstrates that the double-inactivation procedure based on solvent detergent treatment and heating at $100^{\circ} \mathrm{C}$ is efficient against most lipid-enveloped viruses and the non-lipid-enveloped HAV. On the other hand, evidence of parvovirus B 19 transmission suggests that this extremely resistant virus still contaminate plasma-derived concentrates despite heating at a very high temperature. Since parvovirus B19 is considered a marker useful to monitor residual infectivity of concentrates, there is a need to further improve virucidal methods with the goal of inactivating even those viruses as resistant as the parvovirus.

\section{References}

1. Mannucci PM: The choice of plasma-derived clotting factor concentrates. Balliere's Clinical Hematology 1996;9:273-90.

2. Schimpf K, Brackmann HH, Kreuz W, et al: Absence of anti-human immunodeficiency virus types 1 and 2 seroconversion after the treatment of hemophilia A and B or von Willebrand's disease with pasteurized factor VIII concentrate. N. Engl.J. Med 1989:321:/148-52.

3. Di Paolantonio T, Mariani G, Ghirardini A. et al: Low risk of transmission of the human immunodeficiency virus by a solvent-detergent-trea- 
ted commercial factor VIII concentrate. I. Med Virol 1992:36:71-4.

4. Skidmore SJ, Pissi KJ. Mawson SJ, et al: Serological evidence that dry heating of clotting factor concentrates prevents transmission of non-A, non-B hepatitis. J. Med Virol 1990:30:50-2.

5. Mannucei PM, Schimpf K, Abe T, et al: Low risk of viral infection after administration of vapor heated factor VIII concen trates.

Transfiusion 1992:32:1.34-8.

6. Mannucci PM. Schimpf K, Brettler DB, et al: Low risk for hepatitis in hemophiliacs given a high-purity, pasteurized factor VIII concentrate. Aun Intern Med 1990;1/3:27-32.

7. Mariani G. Di Paolantonio T. Baklaya R. et al: Prospective study of the evaluation of hepatitis $\mathrm{C}$ virus infectivity in a high- purity, solvent/detergent-treated factor VIII concentrate: parallel evaluation of other markers for lipidenveloped and non-lipid-enveloped viruses. Trumsfiusion 1993;33:814-8.

8. Mannucci PM. Gdovin S, Gringeri A, et al: Transmission of hepatitis $A$ to hemophilic patients by factor VIII concentrates reated with organic solvent and detergent to inactivate virus. Ann Inte'n Med 1994:120:1-7.

9. Vermylen J, Peerlinck K: Review of the hepatitis A epidemics in hemophiliacs in Europe. Vor Sung 1994:67:8-11.

10. Hepatitis $A$ among persons with hemophilia who received clotting factor concentrate. $M o r b$ Mortal Wkly Rep 1996:45:29-32.

11. Azzi A. Ciappi S. Zakvrzewska K. el al: Human parvovirus $\mathrm{B} 19$ infection in hemophiliacs first infused with two high-purity, virally attenuated factor VIII concentrates. Am.J. Hemarol 1992:39:228-30.

12. Zakvrzewska K. Azzi A. Patou G. et al: Human parvovirus B19 in clotting factor con- centrates: B19 DNA detection by the nested polymerase chain reaction, $B r . J$. Hacmatol 1992:81:407-12.

13. Arrighi S, Rossi R, Borri MG. et al: "In vitro" and in animal model studies on a double virusinactivated factor VIII concentrate. Thromb Huemost 1995:74:868-73.

14. Mannucci PM, Colombo M: Revision of the protocol recommended for studies of safety from hepatitis of clotting factor con centrates. International Society for Thrombosis and Hemostasis. Thromb Haemost 1989:62:532-4. 15. Rubenstein Al, Rubenstein DB. Coughlin J: Combined solvent-detergent and $100^{\circ} \mathrm{C}$ (boiling) sterilizing dry-heat treatment of factor VIII concentrates to assure sterility. Vox Sang 199/:60:60.

16. Frickhofen N, Abkowitz JL, Safford M: Persistent $B 19$ parvovirus infection in patients infected with human immunodeficiency virus type 1 (HIV-1): a treatable cause of anemia in AIDS. Alm Intern Med 1990;113:926-33.

17. Prowse CV: Parvovirus B19 and blood products. Lancer 1994;343:1101.

18. Peerlinck $K$, Amout J,Gilles JG, ct al: A higher than expected incidence of factor VIII inhibitors in multitransfused hemophilia A patients treated with an intermediate purity pasteurized factor VIII concentrate. Thromb Haemost 1993; 69:115-121.

19. Rosendaal FR, Niewenhuis HK, Van den Berg HM,ct al: A sudden increase in factor VIII inhibitor development in multitransfused hemophilia A patients in the Netherlands. Blood 1993:81:2180-2.

20. Pecrlinck K, Amout J, Di Giambattista M, et al: Factor VIII inhibitors in previously treated haemophilia A patients with a double virusinactivated plasma derived factor VIII concentrate. Thromb Haemostas 1997 (in press). 


\section{Chapter 5}

\section{Development of inhibitors}

- Inhibitors to factor VIII in a family with mild hemophilia: molecular characterization and response to factor VIII and desmopressin.

Thrombosis and Haemostasis 74: 619-621, 1995

- Factor VIII inhibitors in mild and moderate-severity haemophilia A.

Thrombosis and Haemostasis 79: 762-766, 1998

- Safety profile of porcine factor VIII and its use as hospital and home-therapy for patients with hemophilia A and inhibitors: the results of an international survey.

Thrombosis and Haemostasis 75: 25-29, 1996

- Home treatment with recombinant activated factor VII in patients with factor VIII inhibitors: the advantages of early intervention.

British Journal of Haematology 104: 22-26, 1999 


\title{
Inhibitors to factor VIII in a family with mild hemophilia: molecular characterization and response to factor VIII and desmopressin
}

\author{
E. Santagostino, A. Gringeri, L. Tagliavacca, P.M. Mannucci
}

From the Angelo Bianchi Bonomi Hemophilia and Thrombosis Center and Institute of Internal Medicine IRCCS Maggiore Hospital and University of Milan, Italy

Thrombosis and Haemostasis 74:619-621, 1995 


\section{Summary}

Inhibitor development in patients with mild hemophilia is a rare event. We report the occurrence of a persistent, high-responding inhibitor in two affected members of a mild hemophilia A family and discuss the therapeutic approaches employed in these patients in terms of their efficacy and effect on antibody titer. Desmopressin was an effective option for bleeding management, because endogenous factor VIII released by DDAVP was less immunogenic than exogenous factor VIII replacement, which invariably triggered anamnestic responses. Genetic analysis performed to investigate whether or not a peculiar molecular lesion accounted for this particular phenotype identified a G-A transversion at nucleotide 6507 in exon 23. This missense mutation has been already described in mild hemophilia $\mathrm{A}$, but not in patients with inhibitors.

\section{Introduction}

The occurrence of anti-factor VIII (FVIII) inhibitor antibodies in mild hemophilia A is considered a rare event. A recent study (1) which evaluated prospectively the development of inhibitors in 81 previously untreated hemophiliacs infused with recombinant FVIII showed that whereas the prevalence of inhibitors was $28 \%$ in 49 patients with severe hemophilia $\mathrm{A}$ and $13 \%$ in 15 moderate hemophiliacs, no inhibitor developed among 17 patients with mild hemophilia (FVIII greater than $5 \mathrm{U} / \mathrm{dl}$ ). In the past inhibitors have been reported in 10 patients with mild hemophilia $(2-11)$ and in all but two cases $(5,8)$ they were of low titer and transient, usually detected following intensive FVIII replacement therapy. In other cases the onset of inhibitor causes a fall of plasma FVIII levels, a concomitant increased frequency and severity of hemorrhages (11) and an anamnestic increase in titer following replacement therapy. Some inhibitors developing in mild hemophilia show a nonlinear (type II) interaction with FVIII $(2,6,7,10)$ and inactivate FVIII only partially (12), so that plasma FVIII levels may remain measurable in patient plasma.

We describe the occurrence of a high-responding inhibitor in two affected members of a mild hemophilia family and how this situation led to an initial diagnosis of severe hemophilia. The different therapeutic approaches employed in these patients are described and their efficacy and effects on inhibitor titers are compared. DNA analysis was performed to identify the molecular basis of the defect, to see whether or not a peculiar molecular lesion could explain this particular phenotype.

\section{Materials and Methods}

FVIII Coagulant Activity: was assayed by a one-stage method (13).

Anti-human FVIII Antibody: was measured in plasma using the Bethesda assay (14).

Antibody to Porcine FVIII: was determined with a modification of the Bethesda assay (15). 
Molecular Genetic Studies. $10 \mathrm{ml}$ blood sample was used for DNA extraction by standart technique. RNA was isolated by acid guanidinium thiocyanate-phenol-chloroform extraction (16) from peripheral blood lymphocytes purified from $10 \mathrm{ml}$ blood by centrifugation through a layer of Histopaque 1077 (Sigma, St. Louis, MO).

Reserve Transcription and Nested PCR. 200-500 ng of total lymphocyte RNA was used as template for CDNA synthesis with 200 units Moloney murine leukaemia virus reverse transcriptase (Gibco BRL, Paisley, UK) and $50 \mathrm{ng}$ of the appropriate oligonucleotide $3^{\prime}$ primer (17). The mixture was incubated at $42^{\circ} \mathrm{C}$ for $1 \mathrm{~h}$. To amplify the FVIII cDNA, the reverse transcriptase reaction mixture was incubated with $500 \mathrm{ng}$ of primer ( $5^{\prime}$ and $3^{\prime}$ outer nest) and $5 \mathrm{U}$ Taq Polymerase (Perkin-Elmer, Norwalk, CT) and 30 cycles of PCR were carried out $\left(93^{\circ} \mathrm{C} 1 \mathrm{~min}, 58^{\circ} \mathrm{C} 1 \mathrm{~min}, 72^{\circ} \mathrm{C} 5 \mathrm{~min}\right) .2 \mu \mathrm{l}$ of the first round product were amplified with $300 \mathrm{ng}$ of primer ( $5^{\prime}$ and $3^{\prime}$ inner nest), and $5 \mathrm{U}$ Taq polymerase (Promega, Madison, WI). The final products were purified by electrophoretic separation on 1\% agarose gel and absorption to Geneclean II (Bio 101, Vista, CA).

DNA Amplification. DNA was amplified in the same solutions described above but for a single round of $30 \mathrm{cycles}\left(93^{\circ} \mathrm{C} 1 \mathrm{~min}, 61^{\circ} \mathrm{C} 30 \mathrm{~s}, 72^{\circ} \mathrm{C} 3 \mathrm{~min}\right.$ ).

Chemical Mismatch Detection and Sequencing. Each amplified PCR product from the patient was denatured and annealed in a 10:1 ratio with the homologous end labeled probe. The hybrids were divided in two aliquots and treated with either hydroxylamine $\left(2.3 \mathrm{M}, 37^{\circ} \mathrm{C}\right.$ for $\left.2 \mathrm{~h}\right)$ or osmium tetroxide $\left(0.025 \%, 37^{\circ} \mathrm{C}\right.$ for $\left.2 \mathrm{~h}\right)$. These steps modify mispaired cytosine $(\mathrm{C})$ and thymine $(\mathrm{T})$ residues (18). Modified products were then cleaved by piperidine $\left(1 \mathrm{M}, 90^{\circ} \mathrm{C}\right.$ for $30 \mathrm{~min}$ ) and sized on $4 \%$ acrylamide gel electrophoresis followed by autoradiography. The region containing mismatch was sequenced by means of the dideoxy sequencing method modified for direct sequencing of double-stranded PCR products (19).

\section{Case Reports}

Two brothers have been attending our Hemophilia Center since 1979, when severe hemophilia A was diagnosed and anti-FVIII antibody was detected in both, at the ages of 23 and 30 years.

Before referral to the Center G. B. P., aged now 39 years, was infused on 13 different occasions with plasma and cryoprecipitate to treat hemarthrosis and post-extraction dental bleeding. At the time of his first visit in 1979, an inhibitor titer of $26 \mathrm{BU} / \mathrm{ml}$ was measured in plasma and FVIII levels were unmeasurable (Fig. 1). Subsequently, high doses of human FVIII concentrate were administered in the attempt to achieve measurable FVIII levels for treatment of spontaneous joint bleeding (knee shoulder, elbow and ankle). Between 1979 and 1983 FVIII levels of less than $1 \mathrm{U} / \mathrm{dl}$ were 
repeatedly measured before replacement therapy, which was always followed by ananmestic antibody response.

On several occasions replacement with human FVIII could not be adopted because the inhibitor titer was higher than $20 \mathrm{BU} / \mathrm{ml}$. In 1983 the patient experienced a severe hemarthrosis, at a time when anti-human and anti-porcine FVIII antibody titers were 11 and $0.7 \mathrm{BU} / \mathrm{ml}$ respectively. $\mathrm{A}$ course of porcine FVIII concentrate (Hyate C, Speywood) yielded measurable plasma FVIII and bleeding stopped. After one week, anti-human and anti-porcine inhibitor titers peaked to 238 and $83 \mathrm{BU} / \mathrm{ml}$ (Fig. 1). During the next years (1984 to 1991), bleeding was treated with human FVII when the inhibitor was less than 10 $\mathrm{BU} / \mathrm{ml}$, but prothrombin complex concentrate (PCC) and recombinant activated FVII (Novoseven, Novo Nordisk) were used when the antibody Fig. 1. Changes in inhibitor levels in relation to the different treatments.

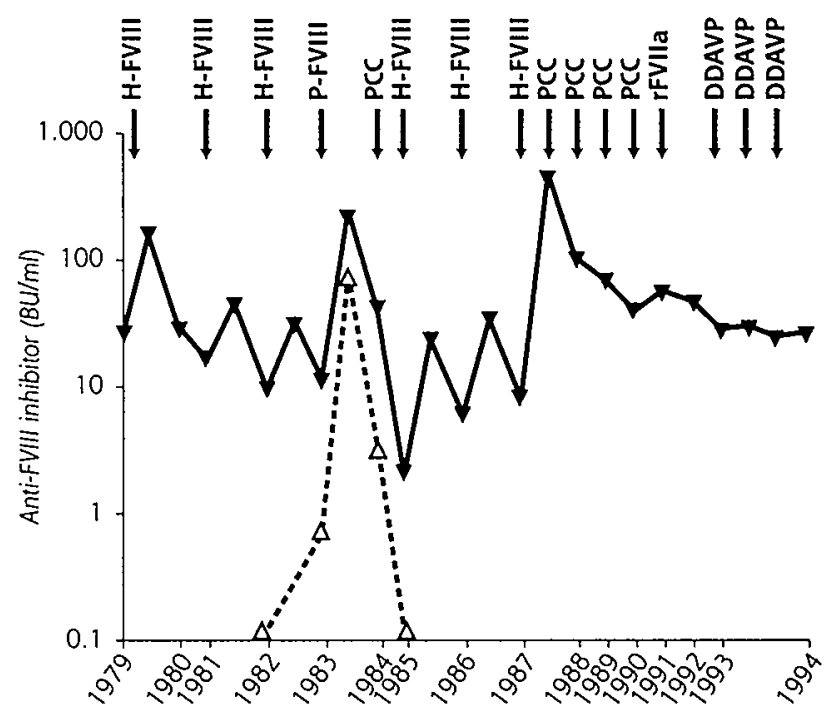

Continued line indicates anti-human FVIII inhibitor. Broken line indicates anti-porcine FVIII inhibitor. Arrows indicate treatment courses with human FVIII concentrate (H-FVIII), porcine FVIII concentrate (P-FVII), prothrombin complex concentrate (PCO, recombinant activated FVII concentrate (rFVIIa) and DDAVP. was higher (maximal historical titer: $455 \mathrm{BU} / \mathrm{ml}$, reached in 1987), with a slight improvement in symptoms (Fig. 1). Recently, after a 2-year period (1991-1993) during which the patient required no therapy, FVIII levels of $9 \mathrm{U} / \mathrm{dl}$ were repeatedly measured in patient plasma, despite antihuman and anti-porcine antibody titers of 28 and $7 \mathrm{BU} / \mathrm{ml}$ (Fig. 1). At this time three bleeding episodes were treated successfully with desmopressin (DDAVP) (Fig. 1). Plasma FVIII increased to $41 \mathrm{U} / \mathrm{dl}$ following the first infusion (DDAVP $0.3 \mathrm{mcg} / \mathrm{kg}$ ) and the response gradually decreased after the next two infusions of the same dose at $24 \mathrm{~h}$ intervals (Fig. 2). A second course of treatment, after a 4-day therapy-free interval, induced a similar pattern of response, with no anamnestic rise in inhibitor titer observed 3 weeks after the first desmopressin infusion (anti-human, FVIII $29 \mathrm{BU} / \mathrm{ml}$ ) (Fig. 2). Subsequently, basal FVIII has been ranging between 7 and $10 \mathrm{U} / \mathrm{dl}$ and spon- 
taneous joint bleedings have been successfully treated with DDAVP with fair clinical responses.

F.P., aged now 46 years, was involved in a car crash when he was 10-year old and received at that time an unknown amount of blood products for severe traumatic bleedings. Before attending our Center in 1979 at the age of 30 years, the patient had no spontaneous bleeding, but he had bled abnormally after dental extractions. At the time

Fig. 2. Response of factor VIII coagulant activity (FVIII: C) to two series of treatment with DDAVP $(0.3 \mathrm{mcg} / \mathrm{kg})$. The vertical arrow indicates each DDAVP infusion.

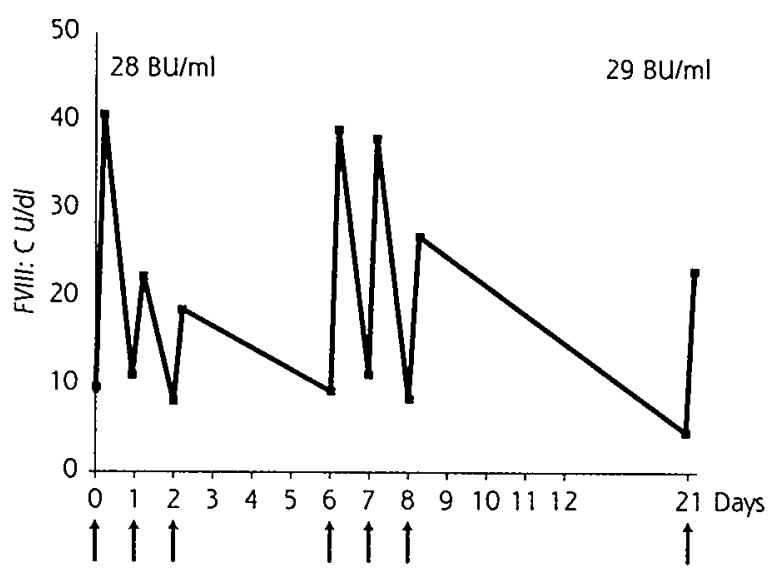

of his first visit, plasma FVIII was unmeasurable and an inhibitor titer of $1 \mathrm{BU} / \mathrm{ml}$ was measured. During the next 12 years (1980-1992), the antibody titer had been always ranging between 1 and $4 \mathrm{BU} / \mathrm{ml}$ before treatment, allowing FVIII replacement therapy. The patient was given cryoprecipitate or high doses of human FVIII concentrate to treat post-traumatic and spontaneous hemarthrosis and episodes of hematuria. Moderate anamnestic response was commonly observed after each treatment with a maximal inhibitor peak of $26 \mathrm{BU} / \mathrm{ml}$ recorded in 1989 following frequent infusions with large amounts of FVIII concentrate for repeated hemarthrosis. In 1993, F.P. was reinvestigated after a prolonged treatment-free interval. He had plasma FVIII levels of $14 \mathrm{U} / \mathrm{dl}$ and an inhibitor titer of $14 \mathrm{BU} / \mathrm{ml}$. A test-infusion of DDAVP was given, with a rise of FVIII to $45 \mathrm{U} / \mathrm{dl}$ after the infusion and no anamnestic response. Basal FVIII levels have been subsequently assayed on various occasions and ranged between 9 and $14 \mathrm{U} / \mathrm{dl}$.

A maternal uncle, previously unknown to us and recently studied, has plasma FVIII level of $12 \mathrm{U} / \mathrm{dl}$, with no measurable inhibitor (less than $0.5 \mathrm{BU} / \mathrm{ml}$ ). Lifelong he had experienced only mild and rare post-traumatic bleeding episodes as expected for the degree of FVIII deficiency.

DNA Studies. Molecular genetic studies were carried out in G.B.P. and the results were confirmed in F.P. The putative promoter, coding sequence and polyadenilation region of the FVIII gene were amplified in 8 overlapping segments either from 
mRNA or genomic DNA (17). Each segment was screened by chemical mismatch analysis to detect and locate any sequence difference between the patient and the control. A mismatch band of $630 \mathrm{bp}$ was detected in a section of reverse transcriptase PCR extending from the $3^{\prime}$ region of the exon 19 to the non-coding $3^{\prime}$ tail of exon 26. Sequence analysis showed a single base pair substitution in exon 23 . The point mutation is a G-A transversion at nucleotide 6507 causing the replacement of arginine by histidine at aminoacid 2150 of FVIII.

\section{Discussion}

The presence in two brothers with hemophilia $\mathrm{A}$ of a persistent high-titer inhibitor masked a mild FVIII defect and led to an initial diagnosis of severe hemophilia. This diagnosis was assumed hecause a high-titer inhibitor and an anamnestic response after FVIII challenge, that occurred particularly in patient G.B.P., typically occur in severe hemophilia.

High doses of human or porcine FVIII concentrates were required to overwhelm the antibody titer and to attain FVIII levels high enough to control bleeding. Sharp rises or the inhibitor always occurred after replacement therapy and on several occasions the presence of high antibody titers led to use FVIII by-passing treatment modalities such as PCC or recombinant FVIIa. When resting FVIII levels became measurable after a prolonged period without exposure to FVIII, we realized that both brothers had mild hemophilia. This assumption was supported by the study of a maternal uncle, who had no inhibitor and mild FVIII deficiency. Even though no detailed study of the antibodv kinetics was done in patients at this stage, it is clear that these antibodies were or became of type II, because their presence in plasma coincided with that of measurable FVIII levels. In the frame of this new situation, DDAVP became an effective option in the management of these patients. Satisfactory hemostasis, in terms of FVIII rise and clinical outcome, was previously reported in two patients with mild hemophilia and inhibitor treated with DDAVP and no anamnestic response was observed in either of them $(9,20)$. Our experience confirms these findings, suggesting that DDAVP represents a less immunogenic alternative to exogenous FVIII.

The finding in a mild hemophilia family of a persistent, high titer inhibitor, which responded differently to exogenous and endogenous FVIII, suggested us that a peculiar molecular lesion might account for this unusual phenotype. Inhibitor formation in severe hemophilia $A$ has been associated with gene deletions $(21,22)$. However, it has been also associated with point mutations (22) and inversion mutations in intron 22 (23), although the latters have been related to a low risk of inhibitor development by other authors (24). Two missense mutations (Arg ${ }^{22 x(y)}$-Gln and Trp ${ }^{2229}$-Cys) have been previously reported in two patients with mild/moderate hemophilia and anti-FVIII 
antibody (22). The missense mutation (Arg ${ }^{2150}$-His) detected in this family, has been already identified in patients with mild/moderate hemophilia $A$, but never associated before to the development of inhibitor (22). Hence, analysis of the molecular defect has not revealed a peculiar pattern in this family with mild hemophilia and an inhibitor characterized by a discrepant response to exogenous and endogenous FVIII.

\section{References}

1. Lusher JM. Arkin S. Abildgaard CF. Schwartz RS, and the Kogenate Previously Untreated Patient Study Group: Recombinant factor VIII for the treatment of previously untreated patients with hemophilia A - Safety, efficacy, and development of inhibitors. $N$ Engl I Med 1993: 328: 453-9.

2. Beck P. Giddings JC, Bloom AL: Inhibitor of factor VIII in mild haemophilia. $B r . J$ Haematol 1969: 17:28.3-8.

3. Strauss HS: Acquired circulating anticoagulants in hemophilia A. N Engl J Med 1969; 281: 866-73.

4. Crowell EB: A factor VIII inhibitor in a mild hemophiliac. Am.J Med Sci 1970; 260: 261-3.

5. Robboy SJ, Lewis EJ, Schun PH. Colman RW: Circulating anticoagulants to factor VIII. Am.I Med 1970; 49: 742-52.

6. Lechner K. Ludwig E. Niessner H, Thaler E: Factor VIII inhibitor in a patient with mild hemophilia A. Hacmostasis 1973: 1: 26/-70. 7. Shapiro SS. Hultin M: Acquired inhibitors to coagulation factors. Semin Thromb Hemost 1975: 1: 336-85.

8. Lowe GDO. Harvie A. Forbes CD, Prentice CRM: Successful treatment with prothrombin complex concentrate of postoperative bleeding in a haemophiliac with a factor VIII inhibitor. Br-Med J 1976; 2: 1110-1.

9. Kesteven PJ, Holland LJ, Lawrie AS, Savidge GF: Inhibitor to factor VIII in mild haemophi- lia. Thomb Haemost 1984; $52: 50-2$.

10. Bovill EG, Burns SL, Golden EA: Factor VIII antibody in a patient with mild hacmophilia. Br.J Haematol 1985:61:323-8. 11. Capel P. Toppet M. Van Remoortel E, Fondu $P$ : Factor VIII inhibitor in mild haemophilia (letter). Br.I Haematol 1986; 62: 786-7.

12. Biggs R. Austen DEG, Denson KWE. Borret R, Rizza CR: The mode of action of antibodies which destroy factor VIII. II. Antibodies which give complex concentration graphs. $\mathrm{Br} J$ Hacmatol 1972; 23: 137-55.

13. Hardisty RM, Macpherson JC: A one-stage factor VIII (anti-haemophilic globulin) assay and its use on venous and capillary plasma Thrombes Diathes Haemorth 1962: 7: 215-21.

14. Kasper CK. Aledort LM. Counts RB. Edson JR, Fratantoni JC, Green D, Hampton JR, Hilgarner MW, Lazerson J, Levine PH, McMillan CW, Pool JG, Shapiro SS, Shulman NR, Van Eys J: A more uniform measurement of factor VIII inhibitors. Thromb Diathes Hacmorh 1975; 34: 869-72.

15. Gatti L, Mannucci PM: Use of porcine factor VIII in the management of seventeen patients with factor VIII antibodies. Thromb Huemost 1984; $51: 379-84$.

16. Chomczynski P. Sacchi N: Single-step method of RNA extraction by acid guanidinium thiocyanate-phenol-chloroform extraction. Anal Biochem 1987; 162: 156-9.

17. Naylor JA, Green PM, Montandon AJ, Rizza 
CR, Giannelli F: Detection of three novel mutations in two hemophilia $A$ patients by rapid screening of the whole essential region of factor VIII. Lancet 1991: 337: 635-9.

18. Montandon AJ, Green PM, Giannelli F, Bentley DR: Direct detection of point mutations by mismatch analysis: application to hemophilia B. Nucleic Acid Res 1989: 17: 3347-58.

19. Green PM, Bentley DR, Mibashan RS. Nilsson IM, Giannelli F: Molecular pathology of hemophilia B. EMBO J.1989; 8: 1067-72.

20. Lowe G, Pettigrew A, Middleton S. Forbes $\mathrm{CD}$, Prentice CRM: DDAVP in haemophilia. Lancet 1977; 2: 614-5.

21. Millar DS, Sternbrecher RA, Weland K, Grundy CB, Martinowitz U, Krawczak M, Zoll B, Whitmore D, Stephenson J, Mibashan RS, Kakkar VV, Cooper DN: The molecular genetic analysis of haemophilia $\mathrm{A}$ : characterization of six partial deletions of the factor VIII gene. Hum Genet 1990: 86: 219-27.

22. Tuddenham EGD, Schwaab R, Seehafer J, Millar DS, Gitschier J. Higuchi M, Bidichandani S. Connor JM. Hoyer LW. Yoshioka A. Peake IR. Olek K, Kazazian HH, Lavergne JM, Giannelli F. Antonarakis SE, Cooper DN: Haemophilia A: database of nucleotide substitutions, deletions, insertions and rearrangements of the factor VIII gene, second edition. Nucleic Acids Res $1994 ; 22: 35 / 1-33$.

23. Tizzano EF, Altisent C, Tusell J, Domenech $M$, Baiyet $M$ : Intron 22 inversions and haemophilia (letter). Lancet 1994; 343:792.

24. Goodeve AC, Preston FE, Peake IR: Factor VIII gene rearrangements in patients with severe haemophilia A. Lancer 1994: 343: 329-30. 


\section{Factor VIII inhibitors in mild and moderate-severity haemophilia $A$}

C.R.M. Hay', C.A. Ludlam², B.T. Colvin', F.G.H. Hill', F.E. Preston', N. Wasseem", R. Bagnall', I.R. Peake', E. Berntorp", E.P. Mauser Bunschoten", K. Fijnvandraat"1, C.K. Kasper" ${ }^{11}$ G. White ${ }^{12}$, E. Santagostino ${ }^{13}$

From the Departments of Haematology, 'Manchester Royal Infirmary, Manchester, 2Royal Infirmary of Edinburgh, ${ }^{3}$ Royal London Hospital, Whitechapel, London, "Birmingham Children's Hospital, Ladywood, Birmingham,

${ }^{5}$ Royal Hallamshire Hospital, Sheffield, UMDS, "Guys Hospital, London, ${ }^{7}$ Dept of Medicine and Pharmacology, University of Sheffield, United Kingdom;

SUniversity Hospital, Malmö, Sweden;

"Van Creveld Kliniek, Academisch Ziekenhuis, Utrecht, Netherlands,

${ }^{10}$ Academic Medical Center, University of Amsterdam, Netherlands;

"Orthopaedic Hospital, Los Angeles, USA,

I2University of North Carolina at Chapel Hill, N Carolina, USA;

${ }_{13}^{3}$ A Bianchi Bonomi Haemophilia Centre, Milan, Italy

Thrombosis and Haemostasis 79: 762-766, 1998 


\section{Summary}

Twenty-six patients with mild or moderate haemophilia $\mathrm{A}$ and inhibitors are described. The inhibitor was detected at a median age of 33 years, after a median of 5.5 bleeding episodes.This usually following intensive replacement therapy. The median presenting inhibitor titre was antihuman $11.6 \mathrm{BU} / \mathrm{ml}$, antiporcine $1.45 \mathrm{BU} / \mathrm{ml}$. Plasma basal factor VIII level declined from a median of $0.08 \mathrm{IU} / \mathrm{ml}$ to $0.01 \mathrm{IU} / \mathrm{ml}$ following the inhibitor development. This caused spontaneous bleeding in 22 and a bleeding pattern similar to acquired haemophilia in 17. Bleeding was often severe and caused two deaths.

The inhibitor disappeared spontaneously, or following immune tolerance induction, in 16 cases after a median of 9 months (range $0.5-46$ ), with a return to the original baseline VIIIC level and bleeding pattern accompanied inhibitor loss. The inhibitor persisted in the remainder of the cases over a median period of 99 months (range $17-433$ months) of follow-up. Inhibitors are an uncommon complication of mild haemophilia which frequently persist and may be associated with severe, life-threatening, haemorrhage.

Forty-one percent of treated haemophilic family members had a history of factor VIII inhibitors, suggesting a familial predisposition to develop inhibitors in these kindreds. Sixteen patients from 11 families were genotyped. Seven different missense mutations affecting the light chain were detected and two in the A2 domain. Five patients from three families had a mutation causing a substitution of $\operatorname{Trp}^{222 y}$ by Cys in the $\mathrm{C} 2$ domain which appears to predispose to inhibitor formation since 7 of the 18 affected individuals have a history of inhibitor development.

\section{Introduction}

The development of a factor VIII inhibitor antibody is a serious complication of replacement therapy which occurs in $20-35 \%$ of patients with severe haemophilia A (13). Patients with major deletions or rearrangements of the factor VIII gene resulting in an absence of circulating factor VIII antigen have a particularly high risk of developing an inhibitor, presumably because exogenous factor VIII is recognised by the immune system as a "foreign protein" (4). These inhibitors reduce the efficacy of factor VIII replacement but have no effect on the clinical presentation or the frequency of haemorrhage.

Inhibitors also arise in patients with mild or moderate severity haemophilia A but are uncommon. The prevalence of inhibitors in this group has been estimated to be between 3 and $13 \%,(1,5,6)$ but very few have been fully described in the literature $(7-17)$. The inhibitors reported commonly arose following intensive replacement therapy and were usually reported to be transient and of low titre $(8,9,11,12,14-17)$. Both type I and type II inhibitor reaction-kinetics have been described $(11,12,15,17)$. A fall in basal 
factor VIII level accompanying the development of the inhibitor was reported in three patients, spontaneous bleeding in five $(15,16,17)$ and soft-tissue haematomas and bruising were reported in one case (15).

A third of new inhibitors reported to the United Kingdom Haemophilia Centre Directors Organisation (UKHCDO) Inhibitor Working Party over the past seven years occurred in patients with mild or moderate severity haemophilia A. Many of these patients developed severe and sometimes life-threatening bleeding and two exsanguinated. The unexpectedly high incidence of these inhibitors, their relatively malign natural history and their hereditary basis was investigated further.

\section{Subjects and methods}

United Kingdom Haemophilia Centre Directors have been sent a brief "tick-box" multipurpose adverse event report card every three months since 1989. This is returned to the Oxford Haemophilia Centre where data retrieval is coordinated and national statistics collated. New inhibitors are reported prospectively and further information sought by the UKHCDO United Kingdom Haemophilia Centre Directors Organisation (UKHCDO) Inhibitor Working Party, using a standard questionnaire. These data, collected between January 1990 and January 1997, were used to calculate the incidence of factor VIII inhibitors arising in patients with severe (VIIIC $<0.02 \mathrm{IU} / \mathrm{ml}$ ), moderate (VIIIC 0.02- $0.05 \mathrm{IU} / \mathrm{ml}$ ) and mild (VIIIC 0.05-0.5 IU/ml) severity haemophilia in the United Kingdom (UK). All patients with mild or moderate severity haemophilia who developed inhibitors in the UK during this period are presented.

Clinical data was also collected retrospectively from US and European clinicians known to have managed such patients and amalgamated with the UK data when describing the natural history, treatment and risk factors for inhibitor development.

Patients were screened for inhibitors when factor VIII recovery declined or the patient began to bleed spontaneously, using the Bethesda assay (18) in 22 cases and the "new Oxford" assay (19) in patients 3 and 4.

Screening for and identification of mutations in the factor VIII gene was carried out as previously described $(20,21)$. Briefly, genomic DNA obtained by standard methods and cDNA obtained by the isolation and reverse transcription of ectopic RNA transcripts from peripheral blood lymphocytes were amplified by polymerase chain reaction (PCR) to yield 8 segments of DNA containing all the essential regions of the factor VIII gene. These segments were then individually screened for sequence changes using fluorescent solid phase mismatch detection (21). Any regions of DNA containing a mismatch were sequenced by means of the dideoxy sequencing method modified for direct sequencing of double stranded PCR product (22).

Summary statistics were calculated using minitab statistical software. 


\section{Results}

Fifty-seven new factor VIII inhibitors were reported to the UKHCDO between January 1990 and January 1997, 16 of which (28\%) arose in patients with mild or moderate severity haemophilia A. The UK registry currently includes 1939 patients with severe, 1615 with moderate and 1546 with mild haemophilia A (23). The annual incidence of inhibitors in the UK is therefore 3.5 per 1000 patients registered with severe haemophilia and 0.84 per 1000 for patients with mild and moderate severity haemophilia.

The clinical features of 26 patients with mild or moderate severity haemophilia A and their inhibitors were fully reported; of these 17 were from the UK. The inhibitor was detected at a median age of 33 years (range 7-71), arising after a median of 5.5 bleeding episodes (range 1-107).

The median presenting antihuman $(\mathrm{H})$ and antiporcine inhibitor titre was $\mathrm{H} 11.6$ $\mathrm{BU} / \mathrm{ml}$ (range 0.5-568) and $\mathrm{P} 1.45 \mathrm{BU} / \mathrm{ml}$ (range $0-61$ ), respectively. This rose to a maximum median titre of $\mathrm{H} 22.5 \mathrm{BU} / \mathrm{ml}$ (range $1.1-1000$ ) and $\mathrm{P} 17.4 \mathrm{BU} / \mathrm{ml}$ (range $0-150$ ) following further treatment. An anamnestic increase in inhibitor titre occurred following factor VIII replacement in $14(70 \%)$ of the 20 patients treated with factor VIII.

Clinical Features. The presence of an inhibitor was suggested by a change in the patient's bleeding pattern in 22 and a post-operative decline in factor VIII recovery and half-life in four patients. This was accompanied by a decline in baseline factor VIII level in 24 patients from a median baseline VIIIC level of $0.08 \mathrm{IU} / \mathrm{ml}$ (range $0.03-0.36$ ) to a median of $0.01 \mathrm{IU} / \mathrm{ml}$ (range 0.0-0.10) (Table 1). Patients 13 and 24 had noncross-reacting inhibitors which did not affect their basal plasma factor VIII levels. The inhibitors in patients 6 and 14 were detected only by a dramatic postoperative decline in factor VIII recovery. In patient 6 , successful immune-tolerance induction was immediately initiated using the Malmö regime (18) and the inhibitor titre never quantified. Patient 14 failed to maintain a circulating factor VIII level from the ninth day following gastrectomy for carcinoma. An inhibitor screen was positive, but the inhibitor was not assayed since he died from uncontrollable GI haemorrhage despite intensive replacement therapy consistently associated with very poor factor VIII recovery.

The development of an inhibitor was accompanied by spontaneous bleeding in 23 of the 26 patients (Table 1). This was characterised by spontaneous haemarthroses and occasional muscle haematoma in five patients, but 17 developed a pattern of bleeding similar to that observed in patients with acquired haemophilia (Table 1). The principal clinical features of this were soft tissue bleeding, with spontaneous and traumatic bruising and muscle haematoma. Gastrointestinal or urinary tract bleeds 
Table 1. Treatment, inhibitor titre, change in basal VIIIC and bleeding pattern

\begin{tabular}{|c|c|c|c|c|c|c|c|}
\hline $\begin{array}{l}\text { PT } \\
N^{0}\end{array}$ & $\begin{array}{l}\text { Age } \\
\text { yrs }\end{array}$ & $\begin{array}{l}\text { Pre-inhib. } \\
\text { Bleeding } \\
\text { Episodes }\end{array}$ & $\begin{array}{l}\text { Basal } \\
\text { VIIIC } \\
\text { IU/ML }\end{array}$ & $\begin{array}{l}\text { Post-inhib } \\
\text { VIIIC } \\
\text { IUIML }\end{array}$ & $\begin{array}{l}\text { Presenting } \\
\text { Anti-Human/Porcine } \\
\text { Titre BU or OU/ML. }\end{array}$ & $\begin{array}{l}\text { Post- } \\
\text { Inhibitor } \\
\text { Treatment\# }\end{array}$ & $\begin{array}{l}\text { Bleeding } \\
\text { Pattern }\end{array}$ \\
\hline 1 & 18 & 8 & 0,05 & 0.01 & $7,3 / 17,4$ & $H, F$ & $c$ \\
\hline 2 & 7 & 107 & 0,05 & 0,01 & $0,5 / 0,0$ & $H$ & b \\
\hline 3 & 53 & 6 & 0,08 & 0.01 & $52.0 / 47.0 \mathrm{ou}$ & $H, P, F$ & c \\
\hline 4 & 35 & 2 & 0.04 & 0.01 & $162,0 / 21 \mathrm{ou}$ & $H, F$ & $c$ \\
\hline 5 & 26 & - & 0.08 & 0,00 & $108,0 / 61,0$ & H. P, F, Iu & 6 \\
\hline 6 & 67 & 7 & 0,06 & 0.01 & SEE TEXT & $H, I$ & SEE TEXT \\
\hline 7 & 48 & 63 & 0,03 & 0.01 & $3,6 / 0,5$ & none & c \\
\hline 8 & 30 & - & 0,14 & 0.01 & $14,0 /--$ & H, F, D & c \\
\hline 9 & 71 & 2 & 0,06 & 0,00 & $1,3 / 0,0$ & $\mathrm{~F}$ & c \\
\hline 10 & 33 & 5 & 0.08 & 0.01 & $23,0 / 5,0$ & $H, P, I^{S}$ & c \\
\hline 11 & 33 & 6 & 0.08 & 0,00 & $8,0 / 1,0$ & H. P & $c$ \\
\hline 12 & 44 & $\cdot$ & 0.04 & 0.00 & $10,0 / 1,0$ & $H, P, I P$ & a \\
\hline 13 & 60 & 2 & 0.10 & 0.10 & $4,0 / 1,0$ & H. P & $a$ \\
\hline 14 & 68 & 8 & 0.12 & 0,00 & SEE TEXT & $H$ & b \\
\hline 15 & 49 & 4 & 0,11 & 0,01 & $67,0 / 1,8$ & $H, P, F$, IP & c \\
\hline 16 & 61 & 5 & 0.36 & 0.01 & $2,0 / 0,0$ & D & c \\
\hline 17 & 60 & 30 & 0.03 & 0,00 & $568 / 16$ & none & c \\
\hline 18 & 19 & 40 & 0.11 & 0.01 & $3,3 / 1.9$ & $\mathbf{H}$ & b \\
\hline 19 & 8 & 1 & 0.06 & 0.00 & $10.21-$. & H, D, IP & c \\
\hline 20 & 23 & 2 & 0.09 & 0.01 & $28,0 / 7,0$ & $H, P, D, F$ & b \\
\hline 21 & 30 & $\cdot$ & 0,12 & 0,01 & $14.0 /--$ & H, D & b \\
\hline 22 & 28 & 10 & 0,08 & 0,00 & $80.0 /--$ & F, D & c \\
\hline 23 & 16 & 4 & 0,05 & 0,05 & $11,2 / 1.1$ & $H, F, D$ & $a$ \\
\hline 24 & 70 & 4 & 0.12 & 0,01 & $12,0 / 0,9$ & $H, P, F, J^{u}$ & $c$ \\
\hline 25 & 19 & 40 & 0.23 & 0.00 & $22,0 / \ldots$ & $H, F, D, \mathbb{P}$ & c \\
\hline 26 & 19 & 3 & 0,23 & 0.05 & 9,0/-- & $F$ & c \\
\hline
\end{tabular}

\# Key to post-inhibitor replacement therapy: $H=$ human VIIIC, $P=$ porcine VIIIC, $F=F E I B A, D=$ DDAVP,

is = successful immune tolerance induction $(I T I), I P=$ partial response to $I T I, 1 \mu=$ Unsuccessful $I T I$

* Key to bleeding pattern: $a=$ unchanged, $b=$ classical severe haemophilia phenotype, $c=$ similar to acquired haemophilia

were also commonly observed in this group, but haemarthroses were relatively uncommon. Bleeding was often severe and sometimes lifethreatening, causing the deaths of patient 14 from uncontrollable gastrointestinal haemorrhage and of patient 24 from retroperitoneal haemorrhage.

Management and Natural History. The frequency of bleeding increased fol- 
lowing inhibitor development, and all but two patients required blood-product replacement therapy which is summarised in Table 1.

Eight patients were successfully treated with DDAVP once adequate circulating factor VIII levels had returned. DDAVP did not cause anamnesis, although five of these patients had high-responding inhibitors.

Immunetolerance induction was attempted in eight patients (Table 1). The Malmö regime (24) was used successfully in two and with a partial response in a further two. The Van Creveld regime (25) was used unsuccessfully in one patient and achieved a partial response in a second. The Bonn regime was used unsuccessfully in one individual and with partial success in a further patient (26).

The inhibitor disappeared spontaneously or following immunetolerance induction in 16 cases after a median interval of 9 months, range 0.5-46 months. None of these inhibitors recurred subsequently during a median follow up period of 37.5 months, range 1-204 months. Inhibitor disappearance was accompanied by a progressive increase in the factor VIII level towards the original baseline value. The inhibitor persisted in 11 patients after a median follow-up period of 99 months, range 17-433 months. There was no obvious link between the factor VIII genotype and the inhibitor titre or natural history. Affected family members were found to be dissimilar in these respects.

Risk Factors for Inhibitor Development. The inhibitors were detected following intensive replacement therapy for surgery, trauma or muscle bleeding in 16/26 cases. No particular bloodproduct was implicated in the development of these inhibitors. Eight had been treated exclusively with cryoprecipitate and twelve with both cryoprecipitate and intermediate-purity factor VIII concentrate. None had been treated with products implicated in recent inhibitor out-breaks (27-29).

A family history of haemophilia A was present in 19 of the patients reported from 11 kindreds (Table 2). These families included 49 individuals with haemophilia A who had been treated with blood products at some time, $20(41 \%)$ of whom had a history of inhibitors including one patient not reported fully for which only basic data are available. Four brother-pairs with moderate haemophilia and inhibitors are reported, including one set of monozygotic twins.

Nine different missense mutations have been identified in 16 patients from eleven families (Table 2). These mutations gave rise to amino acid substitutions in the A2, $\mathrm{Cl}$ and $\mathrm{C} 2$ domains. Substitutions within 100 bases of the $\mathrm{C} 1 / \mathrm{C} 2$ junction were found in nine families and mutations in the A2 domain in the remaining two. Three apparently unrelated UK families have the same Trp ${ }^{222 "}$ Cys mutation and also the same alleles at two factor VIII intragenic VNTRs and so may share a common ancestor. This uncommon mutation results in the substitution of a non polar by an 
Table 2. Natural history, genotype and family history

\begin{tabular}{|c|c|c|c|c|}
\hline \multirow{2}{*}{$\begin{array}{l}\text { PT. } \\
\text { No }^{\circ}\end{array}$} & \multirow{2}{*}{$\begin{array}{l}\text { Elimination } \\
\text { /follow-up } \\
\text { Time (mths) }\end{array}$} & \multicolumn{2}{|c|}{ Genotype } & \multirow{2}{*}{$\begin{array}{l}\text { Family Members with Haemophilia } \\
\text { with or without Inhibitors }\end{array}$} \\
\hline & & NUC. No. & aa-change & \\
\hline 1 & $12 / 133$ & & & No family history of haemophilia A. \\
\hline 2 & $9 / 61$ & $2044 \mathrm{G}-\mathrm{T}$ & Val683.Phe & No family history of haemophilia A. \\
\hline 3 & $8 / 22$ & & & No family history of haemophilia A. \\
\hline 4 & Persists/99 & $6744 \mathrm{G}-\mathrm{T}$ & $\operatorname{Tr} p^{2229-C y s}$ & No family history of haemophilia A. \\
\hline 5 & $26 / 38$ & $6371 \mathrm{~A}-\mathrm{G}$ & Tyr2105-Cys & No family history of haemophilia A. \\
\hline 6 & $0.5 / 6$ & & & No family history of haemophilia A. \\
\hline 7 & Persists/22 & $6853 \mathrm{~T}-\mathrm{A}$ & Phe $2260-11 e$ & Uncle and grandfather lacking inhibitors. \\
\hline 8 & Persists/31 & & & Brother with an inhibitor. No other relatives. \\
\hline 9 & $4 / 25$ & & & No family history of haemophilia A. \\
\hline 10 & $13 / 37$ & ${ }^{6744 G-T}$ & $\operatorname{Trp} 2229-C y s$ & Grandfather and cousin lacking inhibitors. \\
\hline 11 & Persists/119 & $6744 \mathrm{G}-\mathrm{T}$ & $\operatorname{Trp} 2229-C y s$ & [Patients 11 and 12 are brothers and also \\
\hline 12 & $46 / 130$ & $6744 \mathrm{G}-\mathrm{T}$ & $\operatorname{Trp} 2229 \cdot C y s$ & the nephews of patients 13 and 14 . The \\
\hline 13 & $2 / 3$ & $6744 \mathrm{G}-\mathrm{T}$ & $\operatorname{Trp} 2229-C y s$ & kindred includes a further 8 haemophilic \\
\hline 14 & $1 / 1$ & ${ }^{6744} \mathrm{G}-\mathrm{T}$ & $\operatorname{Trp} 2229-\mathrm{Cys}$ & relatives lacking inhibitors (figure)] \\
\hline 15 & $12 / 14$ & $5882 \mathrm{G}-\mathrm{A}$ & Gly2009-Arg & Cousin with haemophilia lacking an inhibitor. \\
\hline 16 & $9 / 15$ & $5595 \mathrm{G}-\mathrm{A}$ & Glu2182.Asp & Brother with haemophilia lacking an inhibitor. \\
\hline 17 & Persists/17 & $6545 \mathrm{G}-\mathrm{A}$ & Arg 2163 -His & Uncle with haemophilia lacking an inhibitor. \\
\hline 18 & $1 / 156$ & & & No family history of haemophilia A. \\
\hline 19 & $6 / 190$ & & & 7 cousins, one with an inhibitor. \\
\hline 20 & Persists/20S & ${ }^{6507 \mathrm{G}-\mathrm{A}}$ & Arg $2150-\mathrm{His}$ & [Patients 20 and 21 are brothers with one \\
\hline 21 & Persists/202 & $6507 \mathrm{G}-\mathrm{A}$ & Arg $2150 . \mathrm{His}$ & haemophilic uncle lacking and inhibitor.] \\
\hline 22 & $12 / 204$ & & & Brother lacking inhibitor. \\
\hline 23 & Persists/433 & & & Brother lacking inhibitor. \\
\hline 24 & Persists/17 & & & Five second-degree relatives lacking inhibitors. \\
\hline 25 & Persists/196 & ${ }^{1834 C-T}$ & Arg $593 . C y s$ & [Patients 25 and 26 are monozygotic twins \\
\hline 26 & $12 / 184$ & ${ }^{183{ }^{\circ} \mathrm{C}-\mathrm{T}}$ & $\operatorname{Arg}^{593} \cdot$ Cys & lacking other haemophilic relative] \\
\hline
\end{tabular}

uncharged polar amino acid and may, therefore, give rise to a conformational change in the $\mathrm{C} 2$ domain. Two mutations result in the replacement of a small hydrophobic residue with an aromatic amino acid or vice versa (Val ${ }^{(\alpha, 3}$ Phe and Phe ${ }^{226(1)} \mathrm{Ile}$ ), while one replaces a small uncharged hydrophilic amino acid with a basic residue (Glye ${ }^{2 \times(x)}$ $\mathrm{Arg}$ ) and two a basic amino acid with another ( $\operatorname{Arg}^{2150} \mathrm{His}$ and $\operatorname{Arg}^{216.8} \mathrm{His}$ ). Three of these mutations, affecting nine individuals, result in the acquisition of a novel Cys residue which may become involved in abnormal disulphide bridges. 
Fig. 1. Family tree showing six generations of an extensive kindred with moderate-severity haemophilia caused by a ${ }^{6744} \mathrm{G}-\mathrm{T}$ mutation resulting in a Trp 2229 -Cys amino acid substitution. 12 family-members have haemophilia $A$ and four have inhibitors

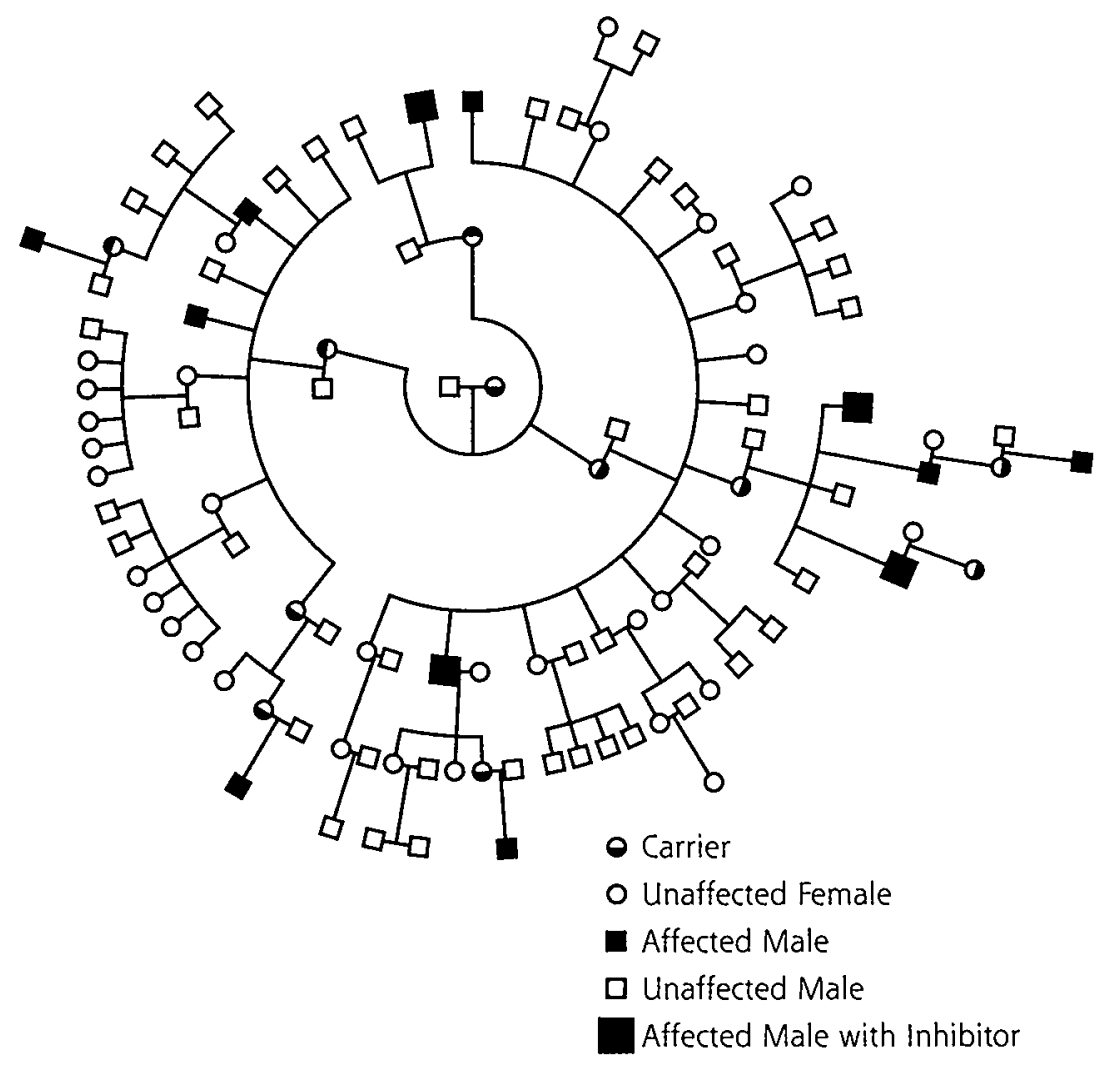

\section{Discussion}

Data collected prospectively over the past six years in the United Kingdom, shows that patients with mild and moderate severity haemophilia A have about a quarter the risk of inhibitor development observed in severe haemophilia. This estimate is consistent with the incidence reported in recently published prospective studies (1-3).

The prevalence of inhibitors amongst the families described in this report is very 
much higher, $41 \%$ of affected family members having a history of inhibitor development. This high prevalence is only partly explained by selection bias. The prevalence of inhibitors amongst the first and second degree relatives of patients reported to us is far greater than would be expected by chance, suggesting that the kindreds described may have a constitutional predisposition to inhibitor development similar in degree to that observed in severe haemophilia.

Kindreds with severe haemophilia caused by mutations associated with severe loss of coding information such as large deletions, inversions and mutations which result in premature translation stops have been shown to have an increased risk of inhibitor formation $(4,30)$. These patients lack circulating factor VIII antigen, and may respond to exogenous factor VIII as a "foreign" protein by forming inhibitor antibodies.

Inhibitor formation in moderate severity haemophilia cannot be explained so easily since these patients have circulating factor VIII, and most have missense mutations $(4,31)$. In some cases the mutation may give rise to conformational changes in the structure of the factor VIII molecule which render the molecule antigenically distinct from "wildtype" factor VIII which would therefore be recognised as "non-self", predisposing the patient to inhibitor formation following factor VIII replacement. Schwaab described such a patient in whom a G-A missense mutation in exon 24 of the factor VIII gene gave rise to moderate severity haemophilia with an VIII:C of $0.07 \mathrm{IU} / \mathrm{ml}$ an VIIIAg of $1.3 \mathrm{U} / \mathrm{ml}$ and a factor VIII inhibitor which arose in adult life (31). Experiments conducted in patient 26 and reported fully elsewhere support this hypothesis (32). His inhibitor antibody was found to react with wild-type factor VIII heavy chain and A2 domain fragments but not with the patient's own factor VIII (32). This suggests that the the $\operatorname{Arg}^{593}$ Cys substitution causing haemophilia in this case results in a structural alteration of the A2 domain such that "wild type" factor VIII is recognised by the patient as "non self" leading to the development of inhibitor antibodies. This is presumably uncommon for mutations giving rise to mild haemophilia.

Nine patients carried missense mutations introducing a new Cys residue (Tyr ${ }^{2105} \mathrm{Cys}$, $\operatorname{Trp}^{22: 0} \mathrm{Cys}$ and $\mathrm{Arg}^{593} \mathrm{Cys}$ ) which may effect the formation of disulphide bridges leading to stable abnormal conformations. Six of these patients are from three apparently unrelated families probably sharing a common ancestor since they have the same mutation and haplotype for two highly polymorphic FVIII intragenic markers. Our findings argue convincingly that their factor VIII mutation strongly predisposes to the formation of factor VIII inhibitor antibodies since these patients are at most distantly related and seven of the 18 affected family members have inhibitors. It is likely that relatively few patients with mild haemophilia will have missense muta- 
tions which predispose towards inhibitor formation by generating a stable immunologically distinct factor VIII. These mutations could then represent a criterion for the prospective identification of kindreds at increased risk.

Most of the mutations detected amongst our patients cause aminoacid changes which result in either a gain or loss of polarity. This may cause these sections of the molecule to become more or less hydrophillic, and are particularly likely to cause conformational changes which lead to loss of factor VIII function and an increased propensity to form factor VIII inhibitors. With two exceptions, the amino acid substitutions were clustered in a restricted region within 100 bases of the junction between the $\mathrm{C} 1$ and the $\mathrm{C} 2$ domain which may represent a "hot spot" for inhibitor development in patients with mild haemophilia. The two remaining mutations affected the A2 domain. These regions are known to bind most of the inhibitory antibodies described in patients with severe haemophilia $(33,34)$.

It is unlikely that the described inhibitors were caused by neoantigens formed during plasma processing since the patients were treated in most cases with low or intermediate-purity products from many different manufacturers and none were treated with any product associated with an unexpectedly high incidence of inhibitors (27-29).

The inhibitors tended to arise relatively early in the patient's treatment history. Two thirds were first detected following intensive replacement therapy for surgery or trauma. Some might have been present earlier at a low level, becoming clinically apparent only after an anamnestic increase in inhibitor titre sufficient to cause a reduction in the baseline VIIIC level.

Most inhibitors came to clinical attention because the factor VIII level fell to $1 \%$ or less following the development of the antibody, presumably because the inhibitor cross-reacts with the patient's own circulating factor VIII. This usually led to spontaneous haemorrhage similar to acquired haemophilia in two thirds of cases. Why the bleeding pattern should differ from that of most patients with congenital haemophilia and inhibitors is unclear. Differences in inhibitor epitope specificity, for example causing steric hindrance of von Willebrand factor binding to platelets may account for the differences in clinical presentation, but this remains to be established $(33,34)$.

Bleeding was often severe, usually requiring replacement therapy and resulting in two deaths. The use of human and porcine factor VIII was limited by anamnesis which occurred in $70 \%$ of patients treated with human factor VIII. FEIBA, recombinant factor VIla and DDAVP did not cause anamnesis even though most of the patients treated with DDAVP suffered a brisk anamnestic response following the use of factor VIII concentrate. DDAVP could only be used when the inhibitor titre had declined and the patient had recovered an adequate level of circulating factor VIII. Immunetolerance induction (ITI) may also be considered, although this strategy was 
successful in only two of the eight patients in whom it was attempted. This response is far less than reported in severe haemophilia, perhaps reflecting the greater age and immunological maturity of patients with mild or moderate severity haemophilia, whose inhibitors usually arise during adulthood.

Although previous reports have emphasised the low-titre and transient nature of the inhibitors described (7-17), our survey has detected high-level inhibitors two thirds of which disappeared spontaneously, or after immunetolerance induction after a median of 12 months, whilst the remainder persisted after a median 99 months of follow-up. Neither persistence of the inhibitor nor inhibitor titre were predicted by the factor VIII genotype, family members being dissimilar in these respects.

These patients develop a severe and persistent bleeding tendency which is relatively or completely refractory to factor VIII replacement therapy and which may be lifethreatening. Recurrence of the inhibitor remains a hazard for patients whose factor VIII inhibitor has disappeared spontaneously. Families potentially at risk may be identified by their family history and factor VIII genotype. This risk should be considered when treating family-members of such patients and DDAVP used wherever possible.

\section{Acknowledgement}

We thank the following for contributing data and samples for DNA analysis from their patients: Dr T Baglin, Addenbrooke's Hospital, Cambridge; Dr P BoltonMaggs, Alder Hey Hospital, Liverpool; Dr P Giangrande, Churchill Hospital, Oxford; Dr M Laffan, Hammersmith Hospital, London; Prof CA Lee, Royal Free Hospital and Medical School, London. Patients 16 and also patients 20 and 21 are reported more fully in references 32 and 17 , respectively.

The factor VIII genotyping of UK patients which took place at UMDS was supported by MRC grant no G9500698MB and supervised by Prof F Giannelli and Dr Peter Green. We are particularly grateful to Professor Giannelli for his help and his constructive criticism of the manuscript.

\section{References}

1. Lusher JM, Arkin S. Abildgaard CF, Schwarz RS: Recombinant factor VIII for the treatment of previously untreated patients with haemophilia A. N Eng.I Med 1993; 328: 453-9.

2. Ehrenforth S, Kreutz W, Scharrer I, Linde R,
Funk M, Gungor $T$ : Incidence of development of factor VIII and IX inhibitors in haemophiliacs. Lancet 1992; 339: 594-8.

3. Addiego J. Kasper CK, Abildgaard C,

Hilgartner M, Lusher J. Glader B, Aledort L: 
Frequency of inhibitor development in haemophiliacs treated with low-purity factor VIII. The Lancet 1993; 342: 402-4.

4. Schwalab R. Brackmann HH, Meyer C. Seehafer J. Kirchgesser M. Hack A. Olek K. Tuddenham EGD. Oldenberg J: Haemophilia A: Mutation type determines risk of inhibitor formation. Thromb Hacmost 1995: 74: (6): 1402-6.

5. Sultan Y, and the French Hemophilia Study Group: Prevalence of inhibitors in a population of 3435 hemophilia patients in France. Thromb Haemost 1992: 67: 600-2.

6. Rizza CR. Spooner RGD: Treatment of haemophilia and related disorders in Britain and Northern Ireland during 1976-80: report on bchalf of the directors of haemophilia centres in the United Kingdom. British Medical Journal 1983; 286: 929-32.

7. Beck P. Giddings JC, Bloom AL: Inhibitor of factor VIII in mild haemophilia. British $J$ Haematol 1969: 17: 283-8.

8. Strauss HS: Acquired circulating anticoagulants in hemophilia A. N Eng. I Med 1969; 281: $866-73$.

9. Crowell EB. A: factor VIII inhibitor in a mild hemophiliac. Am J Med Sci 1970; 260. $261-3$.

10. Robboy SJ, Lewis EJ, Schun PH, Colman RW: Circulating anticoagulants to factor VIII. Am J Med 1970; 49: 742-52.

11. Lechner K, Ludwig E. Niesner $H$, Thaler E: Factor VIII inhibitor in a patient with mild hemophilia A. Haemostasis 1970; 1: 26I-70.

12. Shapiro SS. Hultin M: Acquired inhibitors to blood coagulation factors. Seminars in Thromb Hecemost 1975; 1: 336-85.

13. Lowe GDO, Harvie A. Forbes CD, Prentice CRM: Successful treatment with prothrombin complex concentrate of postoperative bleeding in a haemophiliac with a factor VIII inhibitor. Brit Med I 1976: 2: 1110-1.

14. Kesteven PJ. Holland LJ. Lawrie AS.
Savidge GF: Inhibitor to factor VIII in mild haemophilia. Thromb Haemost 1984: 52: (l): 50-2.

15. Bovill EG, Burns SL, Golden EA: Factor VIII antibody in a patient with mild hacmophilia. Brit I Haematol 1985; 61: 32.3-8. 16. Capel P. Toppet M, Van Remoortel E. Fondue P: Factor VIII inhibitor in mild haemophilia. (letter) Br.J Hacmatol 1986; 62: 786-7.

17. Santagostino E. Gringeri A. Tagliavacca $L$. Mannucci PM: Inhibitors to factor VIII in a family with mild hemophilia: molecular characterisation and response to factor VIII and desmopressin. Thromb Hacmost 1995: 74: (2): 6/9-21.

18. Kasper CK. Aledort LM, Counts RB, Edson JR. Frantoni J. Green D, Hampton JW, Hilgartner $M W$, Lazerson J, Levine PH, McMillan CW, Pool JG, Shapiro SS, Shulman NR, Van Eys J: A more uniform measurement of factor VIII inhibitors. Thrombosis of Diathesis Hacmorthagica 1975; 34: 869-72.

19. Rizza $C$, and Biggs $R$ : The treatment of patients who have factor VIII antibodies. $B$ r I Hacmatol 1973; 2.4: 65-82.

20. Naylor JA, Green PM, Montandon AJ. Rizza CR. Giannelli F: Detection of three novel mutations in two hemophilia $A$ patients by rapid screening of the whole essential region of factor VIII. Lancet 1991: 337:635-9.

21. Montandon AJ, Green PM, Giannelli F, Bentley DR: Direct detection of point mutations by mismatch analysis: application to haemophilia B. Nucleic Acid Res 1989: 17:3347-58.

22. Green PM. Bentley DR. Mibashan RS. Nilsson IM. Giannelli F: Molecular pathology of haemophilia B. EMBO I 1989: 8:1067-72. 23. United Kingdom Haemophilia Centre Directors Organisation. Annual Returns for 1994. Copyrigh UKHCDO 1995. 
24. Nilsson IM, Berntorp E, Zettervall O: Induction of immune tolerance in patients with haemophilia and antibodies to factor VIII by combined treatment with intravenous IgG, cyclophosphamide and factor VIII. $N$ Eng J Med 1988: 318: 947-50.

25. Mauser-Bunschoten EP, Niewenhuis HK, Roosendaal G, van den Berg HM: Low-dose immune tolerance induction in hemophilia $A$ patients with inhibitors. Blood 1995; 86: 983-8. 26. Brackmann HH, Oldenberg J, Schwaab R: Immune tolerance for the treatment of factor VIII inhibitors - twenty years' of the "Bonn Protocol". Vox Sanguinis 1996; 70: (suppl. l): 30-35.

27. Peerlinck K. Arnout J. Gilles JG, SaintRemy JM, Vermylen J: A higher than expected incidence of factor VIII inhibitors in multitransfused haemophilia A patients treated with an intermediate purity pasteurised factor VIII concentrate. Thromb Haemost 1993; 69: $115-8$

28. Mauser-Bunschoten EP, Rosendaal FR, Nieuwenhuis HK, Roosendaal G, Briet E, van den Berg HM: Clinical course of factor VIII inhibitors developed after exposure to a pasteurised dutch concentrate compared to classical inhibitors in haemophilia A. Thromb Hacmost 1994; 71: (6): 703-6.

29. Rosendaal FR: Factor VIII inhibitors on a SD-treated and pasteurised concentrate associated with specific batches and batch characteristics. Thromb Haemost 1997, suppliment; 590 .
30. Tuddenham EGD, Schwaab R, Seehafer J, Millar DS, Gitcher J, Higuchi M, Bidichandani S, Connor JM, Hoyer LW, Yoshioka A, Peake IR, Olek K, Kazazian HH, Lavergne JM, Giannelli F, Antoniarakis SE and Cooper DN: Haemophilia A: database of nucleotide substitutions, deletions, insertions and rearrangements of the factor VIII gene, second edition. Nucleic Acids Research 1994; 22 : 351I33.

31. Schwaab R, Ludwig M, Oldenburg J, Brackmann HH, Egli H, Kochhan L, Olek K: Identical point mutations in the factor VIII gene that have different clinical manifestations of haemophilia A. American I of Human Genetics 1990; 47: 743-744.

32. Fijnvandraat $K$, Turenhout EAM, van den Brink EN, ten Cate JW, Mouril JA, Peters M, Voorberg J: The missense mutation $\mathrm{Arg}^{393}$-Cys is related to antibody formation in a patient with mild haemophilia A. Blood 1997, 89; 4371-77.

33. Scandella $D$, Timmons $L$, Mattingly $M$, Trabold N, Hoyer LW: A soluble recombinant factor VIII fragment containing the A2 domain binds to some human anti-factor VIII antibodies that are not detected by immunoblotting. Thromb Haemost 1992; 67: 665-9.

34. Scandella D, Mattingly M, Prescot R: A recombinant factor VIII A2 domain polypeptide quantitatively neutralises human inhibitor antibodies that bind to A2. Blood 1993; 82: 1767-72-4. 


\title{
Safety profile of porcine factor VIII and its use as hospital and home-therapy for patients with haemophilia-A and inhibitors: the results of an international survey
}

\author{
C. R. M. Hay, J. N. Lozier', C. A. Lee'2, M. Laffan², F. Tradati', \\ E. Santagostino, N. Ciavarella ${ }^{4}$, M. Schiavoni ${ }^{4}$, H. Fukui', A. Yoshiokas, \\ J. Teitel', P. M. Mannucci ${ }^{3}$, C. K. Kasper? \\ From the University Dept of Haematology, Royal Liverpool \\ University Hospital, Prescot St, Liverpool UK; \\ 'Division of Haematology, University of North Carolina at Chapel Hill, NC, USA; \\ 2 Dept of Haematology, Royal Free Hospital and Medical School Pond St, London, UK; \\ ${ }^{3}$ Haemophilia and Thrombosis Centre A. Bianchi Bonomi, Milan, Italy; \\ ${ }^{4}$ Ospedale Consorziale-Policlinico, Bari, Italy; \\ ${ }^{5}$ Dept of Paediatrics, Nara Medical University, Kashihara City, Japan; \\ ${ }^{6}$ Division of Haematology, University of Toronto, St Michaels Hospital, Toronto, Canada; \\ 7University of Southern California and Orthopaedic Hospital, Los Angeles, CA, USA
}

Thrombosis and Haemostasis 75:25-29, 1996 


\section{Summary}

A multicentre retrospective survey was conducted to re-assess the use of porcine factor VIII (HYATE:C), its side effects and the selection of patients for regular of home-therapy. 15,152,000 units of HYATE:C were used by 154 patients. The median inhibitor cross-reactivity to porcine VIIIC of 137 patients was $15 \%, 27 \%$ of patients lacking cross-reactivity. An absent, intermediate or brisk specific antiporcine anamnestic response was observed in 29,40 and $31 \%$ patients respectively. Seven patients were treated on-demand as hometherapy for a median 6.2 , range $1.5-13$ years. 23 further patients were treated regularly in hospital for a median of 3, range 2-7 years. This group used $8.319,000 \mathrm{U}$ of porcine VIIIC for 2,000 bleeding episodes.

The incidence of transfusion reactions was $0.001 \%, 0.64 \%$ and $2.3 \%$. for domiciliary infusions, respectively. The risk of reactions was dose-related. A post-infusion fall in platelet count was common, but usually transient and clinically insignificant. This was also dose-related $(r=-0.64, p=0.002)$. Marked reductions in platelet count were occasionally seen, usually with intensive replacement therapy. The relative lack of side effects observed amongst patients treated at home is attributable to the low, median $33 \mathrm{U} / \mathrm{kg}$, dose used by this group.

A subgroup of inhibitor patients, identifiable by their absent or modest anamnestic response to porcine factor VIII may be treated regularly and safely with this product in small doses, over a period of years.

\section{Introduction}

Polyelectrolyte-fractionated porcine factor VIII (HYATE:C, Speywood Pharmaceuticals Ltd., UK) has been used for the treatment of patients with congenital haemophilia and inhibitors since 1980 (1-4). This product is most commonly used for the management of severe bleeding in patients with intermediate of hightitre inhibitors to human VIIIC, and is often used as second or third-line therapy for patients who fail to respond to human VIIIC or prothrombin complex concentrates (PCCs). The relatively high perceived cost of the product and the risk of side effects such as anamnesis, transfusion reactions and thrombocytopenia have discouraged many clinicians from considering this product as first-line therapy or for less serious bleeding episodes and for regular replacement therapy (2-4, 8-10). Reactions have been reported following $3-7 \%$ of infusions $(2-4,8,9)$. These have usually been described as mild (2-4), although a third of the reactions reported by Gringeri were considered moderate or severe (8). Anaphylaxis appears to be rare (10).

Clinical studies of HYATE: $C$ have described post-infusion reductions in platelet count, but the frequency and severity of this side effect is disputed (1-3,9). Early series report a fall in platelet count after $11 \%$ of fewer infusions (1-3). This contrasts 
with the series of Gringeri et al., in which a fall in platelet count was observed during each of 63 courses of treatment, $16 \%$ of which were accompanied by thrombocytopenia (8). The divergence between these reports was not thought to be accounted for by differences in patient monitoring.

Our experience $(11,12)$ suggested that the side effects of HYATE:C are less frequent and troublesome than has been suggested $(8,11)$, and that a sub-group of inhibitor patients might be treated with porcine factor VIII repeatedly or on-demand $(11,12)$, although the safety of this approach has been questioned (8). This was investigated retrospectively using a comprehensive standardised questionnaire.

\section{Methods}

A standard four-page questionnaire was circulated by CRMH and JNL and with the minutes of the ISTH Factor VIII and IX Scientific Standardisation Subcommittee. Each questionnaire was designed to retrieve the complete treatment history of replacement with porcine VIIIC from single patient.

This included historical peak inhibitor levels, body weight, indication for use, dosage, efficacy, factor VIII increment, inhibitor measurements, cross-reactivity, anamnesis, transfusion reactions and post-infusion changes in platelet count. Additional pages were used for multiply treated patients and respondents were encouraged to provide discharge summaries and computer print-outs of their laboratory and treatment records.

Cross-reactivity was taken as the ratio of anti-human to anti-porcine inhibitor titre measured using the Bethesda method (13) and expressed as a percentage.

Many patients had been treated with human factor VIII before HYATE:C so that it was impossible to be sure whether an absolute rise in anti-human or anti-porcine inhibitor titre was attributable to the treatment with human VIIIC of porcine VIIIC, or both. For this reason, an increase in inhibitor cross-reactivity to porcine factor VIII was taken as evidence of a specific anti-porcine factor VIII anamnestic response and the magnitude of the specific antiporcine anamnestic response was defined in there terms. Brisk and intermediate specific anti-porcine anamnestic responses were defined as more or less than a 3 -fold increase in cross-reactivity, respectively.

The risk of transfusion reactions was related to dose by comparing the incidence of reactions in dose bands 0-50 U/kg, 50-100 U/kg, etc, with $95 \%$ confidence intervals calculated using Poisson tables. Spearman's correlation coefficient was used to investigate the relationship between the post-infusion change in platelet count and the dose of porcine VIIIC administered.

Patients who used HYATE:C as home-therapy were compared with those treated only in hospital. 


\section{Results}

154 patients from 54 centres were reported, treated between 1981 and 1992. These patients had been treated for 2,472 bleeding episodes, including prophylaxis. $15,152,000 \mathrm{U}$ of porcine VIIIC were used, approximately 4,500,000 U (29.7\%) of which were used as home-therapy. Most infusions were of doses less than $50 \mathrm{U} / \mathrm{kg}$. A breakdown of the dosage is given in Table 1.

Table 1. The incidence of transfusion reactions according to dose

$\begin{array}{lccc}\begin{array}{l}\text { Dose-Range } \\ (\mathrm{U} / \mathrm{KG})\end{array} & \begin{array}{l}\text { No. of } \\ \text { Infusions }\end{array} & \begin{array}{l}\text { Reactions } \\ \text { per } 1000 \\ \text { Infusions }\end{array} & 95 \% \mathrm{Cl} \\ <50^{*} & 2942 & 4 & 1.09-10.24 \\ 50-99 & 1331 & 10 & 4.79-18.39 \\ 100-149 & 291 & 82 & 65.22-101.78 \\ >150 & 147 & 82 & 65.22-101.78\end{array}$

" reactions considered "idiosyncratic" rather than dose-related are also included in this estimate.

Fig. 1. Histogram of pre-treatment inhibitor cross-reactivity to porcine VIIIC in 147 patients

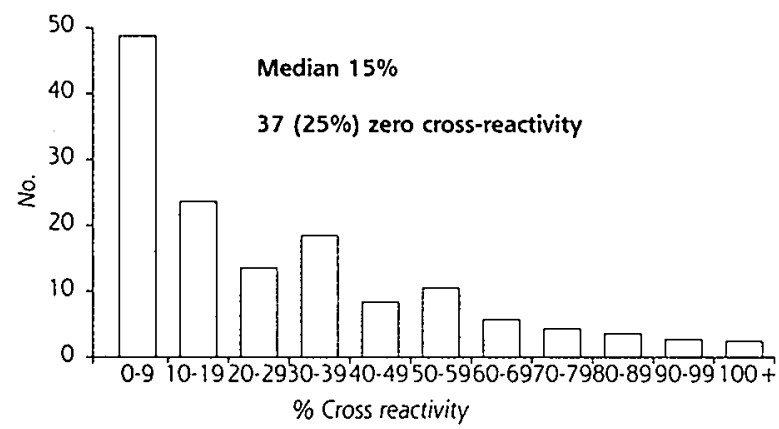

Cross-reactivity. The median pre-treatment cross-reactivity of the 147 patients for whom data was available was $15 \%$, range 0 200\%. 37 patients (27\%) had no measurable cross-reactivity (Fig. 1). $2 \%$ of patients had $>100 \%$ cross-reactivity despite no previous treatment with porcine VIIIC.

Indication for Treatment. The 491 bleeding episodes managed in hospital including 264 haemarthroses, 93 muscle bleeds, 16 episodes of intracranial bleeding, 57 surgical interventions (35 emergency, 22 elective), 13 episodes of trauma and 48 other bleeds. Replacement therapy in these patients for surgery is described in greater detail by Lozier et al. (14). The remaining 1,981 episodes treated outside hospital were routine haemarthroses, prophylaxis or episodes of minor trauma.

Regular Replacement with Porcine VIIIC. Seven patients with high-responding inhibitors and pre-treatment cross-reactivity of $0-30 \%$, used porcine VIIIC routinely, at home, for a median of 6.2, range $1.5-13$ years. In each case, regular replacement with HYATE: $C$ was started at a time when the patients were refractory to human factor VIII but suffering regular haemarthroses with a deteriorating quality of life. Treatment was initiated under close hospital supervision. Home therapy was initiated after several 
months of hospital-based treatment uncomplicated by reactions or anamnesis. Four used $20 \mathrm{U} / \mathrm{kg}$ on-demand every two to four weeks for haemarthroses. Three used 50-60 U/kg every day and then every second day as prophylaxis. The median dose used was used was 33.1 , range $20-60 \mathrm{U} / \mathrm{kg}$. A total of $4,583,000 \mathrm{U}$ of porcine VIIIC, in $3,418 \mathrm{infu}$ sions, were used by this group. Clinical efficacy was reported to be excellent in all of these patients but one, who became resistant to porcine replacement therapy because of the development of a specific anti-porcine factor VIII inhibitor after two years of prophylaxis.

The high-responding anti-human factor VIII inhibitors disappeared in six of these patients during treatment with porcine VIIIC (9). All of these patients developed specific anti-porcine inhibitors. These were detectable on only a single occasion in three, but rose to a peak of $1.5,1.5$ and $2 \mathrm{BU} / \mathrm{ml}$ in a further three patients, disappearing in each case with continued regular porcine factor VIIl replacement therapy. These specific inhibitors did not compromise clinical efficacy which was excellent in six of the seven patients throughout their treatment with HYATE:C. One further patient developed an anti-porcine inhibitor which rose progressively to $6 \mathrm{BU} / \mathrm{ml}$ after two years of prophylaxis with porcine VIIIC causing him to become refractory to HYATE:C. Having lost his original inhibitor, he was successfully established on home-therapy with human VIIIC.

Home-therapy with human factor VIII was reintroduced in four patients, without recurrence of the original high-responding inhibitor, suggesting that they had achieved tolerance to human VIIIC through treatment with porcine VIIIC (9). The remaining three patients refuse treatment with human VIIIC and continue therapy with HYATE:C. Their reasons for refusing human VIIIC include fear or viral infection in two, and life-threatening transfusion reactions to human VIIIC in one.

The original anti-human factor VIII antibody has recurred in only one patient, at a titre of $1.5 \mathrm{BU} / \mathrm{ml}$, after five years treatment on-demand with porcine VIIIC. Intensive replacement therapy with porcine VIIIC for hip arthroplasty was accompanied by the disappearance of this inhibitor which has not recurred during three further years of follow-up. Twenty-three further patients were treated intermittently or regularly on-demand in hospital for a median of 6.5, range 5-24, bleeding episodes over a median period of 3 , range 2-7 years. These patients were given 499 infusions of median dose $99 \mathrm{U} / \mathrm{kg}$, range $22-300 \mathrm{U} / \mathrm{kg}$, totalling $3,735,584 \mathrm{U}$ of porcine VIIIC. An anamnestic increase in crossreactivity to porcine VIIIC was observed following at least one course of treatment in 12 of these patients.

Side Effects. Reactions. The incidence of reactions in a domiciliary setting following a median dose of $33.1 \mathrm{U} / \mathrm{kg}$ was $0.001 \%(\mathrm{n}=2$, both mild). The incidence of reactions amongst the 30 multiply treated in-patients following a median dose of 99 
$\mathrm{U} / \mathrm{kg}$ was $0.64 \%$ ( $\mathrm{n}=24,16$ mild, 8 moderate). The incidence of reactions following unselected in-patient infusions was $2.3 \%$ (70 reactions following 2,980 infusions, 45 mild, 24 moderate, 1 severe). 28 in-patient infusions could not be included in this analysis because the reaction page of the questionnaire was not returned.

Two patterns of transfusion reaction were observed, dose-related and idiosyncratic. The majority were dose-related or occasional. These were isolated, usually occurred with doses $>100 \mathrm{U} / \mathrm{kg}$, and did not recur with subsequent treatment and smaller doses. Although the over-all risk of reactions was low, the incidence of reactions increased significantly with dose (Table 1).

$5 / 154$ patients suffered repeated reactions using doses of $60 \mathrm{U} / \mathrm{kg}$ of less. This suggested an idiosyncratic response. 16 reactions were re-ported in this group, with 2-5 reactions per patient, 14 of which were mild and two of moderate severity. These reactions all occurred within the first five lifetime exposures to porcine VIIIC.

Effect on platelet count. Platelet counts were reported pre and post 175 infusions in 57 individuals following a median dose of $96 \mathrm{U} / \mathrm{kg}$. The platelet count declined by $>20 \mathrm{x}$ $10 \%$ following $61 \%$ of these infusions

Table 2. The anamnestic response following the first treatment episode.

$\begin{array}{lll}\text { RESPONSE } & N(\%) & \text { MEAN (SD) } \\ & \text { TOTAL DOSE U/KG }\end{array}$

BRISK

20

INTERM.

NONE

$\begin{array}{ccr}783 & \text { PRE-TREATMENT } & 3.2 \\ & & 0-61 \\ (688) & \text { POST-TREATMENT } & 88.5 \\ & & 16-500 \\ 763 & \text { PRE-TREATMENT } & 7.5 \\ & & 0-80 \\ (798) & \text { POST-TREATMENT } & 20.4 \\ & & 1-96 \\ 773 & \text { PRE-TREATMENT } & 44 \\ & & 0-100 \\ (881) & \text { POST-TREATMENT } & 26 \\ & & 0-100\end{array}$

from a median of $250 \times 10^{9} / 1$ pre-infusion to $205 \times 10^{\%} / 1$ post-infusion, a median fall of $34 \mathrm{x}$ $10 \%$ l. Larger reductions in platelet count were usually associated with intensive replacement therapy over several days for surgery or trauma. Abnormal bleeding was not reported.

The platelet count was measured pre-infusion and at $30 \mathrm{~min} \mathrm{1,8} \mathrm{min}$ and $24 \mathrm{~h}$ following 21 single infusions in 12 patients. The platelet count fell following $9 / 21$ infusions, reaching a nadir 30 min post-infusion and recovering to pre-treatment values within an hour after all but two infusions. The 30 min post-infusion change in platelet count correlated inversely with the dose $(\mathrm{U} / \mathrm{kg})$ administered $(\mathrm{r}=-0.64, \mathrm{p}=0.002)$. 
Anamnesis. HYATE:C replacement often followed infusion of human VIIIC, preventing a direct assessment of the effect of porcine VIIIC alone on the inhibitor titre. The specific anti-porcine anamnestic response, as reflected by a post-treatment increase in cross-reactivity following the first course of treatment, was evaluable in 65 patients (Table 2). The specific anamnestic response was absent, intermediate or brisk in about a third of patients each. The magnitude of the initial anamnestic response was unrelated to treatment intensity, the three groups having been treated with similar doses of HYATE:C (Table 2). The specific Table 3. The anamnestic response following multiple treatments.

$\begin{array}{lcccc}\text { RESPONSE } & \text { N (\%) } & \begin{array}{c}\text { MEAN (SD) } \\ \text { NO. OF COURSES }\end{array} & \text { SAMPLE } & \begin{array}{c}\text { MEDIAN } \\ \text { RANGE XR \% }\end{array} \\ \text { BRISK } & 4 & 2.33 & \text { INITIAL } & 43 \\ & & & & 6-66 \\ & (7.5) & (0.57) & \text { FINAL } & 236 \\ \text { INTERM. } & 28 & & & 100-604 \\ & & 13 & \text { INITIAL } & 6.7 \\ & (54) & (43) & \text { FINAL } & 0-100 \\ \text { NONE } & 20 & 89.1 & \text { INITIAL } & 48 \\ & & & & 1.5-300 \\ & (38) & (231) & \text { FINAL } & 0.93 \\ & & & & 14 \\ & & & & 0-74\end{array}$
anamnestic response was evaluable in 52 patients who had been treated on at least five occasions with HYATE:C (Table 3). Twenty patients, including all but one of the patients given home-therapy, had no increase in antibody cross-reactivity to porcine VIIIC.

\section{Discussion}

We report almost 2,500 bleeding episodes occurring in 154 patients treated in 54 centres with more than 15,000,000 U of HYATE:C. $80 \%$ of these episodes were routine haemarthroses treated in a domiciliary setting by six centres. Only half of in-patient treatment episodes were for joint bleeding, however, suggesting that many clinicians reserve HYATE:C only for more severe bleeding episodes.

The median pre-treatment inhibitor cross-reactivity was $15 \%, 27 \%$ of patients having no measurable cross-reactivity. Wide variation in pre-treatment cross-reactivity were observed in this group, $2 \%$ of patients having greater than $100 \%$ cross-reactivity. The choice of therapeutic material should, therefore, be based on the clinical circumstances, the current inhibitor titre measured with human and porcine factor VIII, and the past anamnestic response.

Seven patients used small doses of HYATE:C as home-therapy for periods of up to 13 
years. These patients were characterised by their low $0-30 \%$ cross-reactivity, and by the absence of anamnesis or transfusion reactions. About $15 \%$ of inhibitor patients might be suitable for such an approach, since at least $45 \%$ of our patients had $<30 \%$ cross-reactivity and a third had no specific anti-porcine anamnestic response following the use of HYATE:C.

The clinical response was excellent in this group, resulting in a considerable improvement in quality of life. These patients obtain normal or near-normal factor VIII recovery using small doses of HYATE:C. This was therefore an extremely cost-effective form of treatment in this subset of patients who were either refractory of would respond only to large doses of human VIIIC. This approach had the further advantage that six of the patients achieved immune-tolerance to human VIIIC through their treatment with porcine VIIIC. There patients all had high-responding inhibitors which would have been difficult to tolerise conventionally and would have been refractory to factor VIII replacement for a large part of any course of conventional immuno-tolerance induction (12). The perceived risk of side effects such as reactions and thrombocytopenia has discouraged many clinicians from using HYATE:C as home therapy. This survey puts these risks into context and demonstrates that these side effects are largely dose-related. The differences in the incidence of side effects reported in earlier series may reflect differing clinical practices in the centres involved since it is our impression that those centres who tend to treat their patients intensively report a higher incidence of side effects than centres who habitually use more modest doses.

The side effects of treatment were less frequent and troublesome amongst these patients than has been reported by others $(3,8)$. Reactions followed $2.3 \%$ of unselected inpatient infusions, an overall incidence similar to that reported by Brettler (4), though reactions of moderate severity were more frequent in our series. Most reactions appeared to be dose-related insofar as they were isolated and occurred only with larger doses. Although the overall risk of reactions was low, the incidence of reactions correlated strongly with the dose administered (Table 1). The infusion-rate may also be important since large doses tend to be infused more rapidly $(2,12)$. Large doses of HYATE:C should be infused slowly and under hospital supervision, for this reason. Occasional patients (five of 154) suffered repeated idiosyncratic reactions of mild or moderate severity with small doses of HYATE:C. Fortunately, these complications arose early, both in this series and that of Gringeri (8), permitting these patients to be identified and withdrawn from further treatment.

The $0.001 \%$ incidence of transfusion reactions in a domiciliary setting was particularly low. This reflects the small median dose of $33 \mathrm{U} / \mathrm{kg}$ used and the early exclusion from consideration for home-therapy of patients suffering idiosyncratic reactions. After an initial period of closely supervised therapy on-demand those patients who suffer no 
reactions or anamnesis may safely use small doses of porcine VIIC at home.

A fall in platelet count was observed following $60 \%$ of in-patient infusions but was generally clinically insignificant and appeared to recover within an hour in most cases. The platelet count was not monitored following home-therapy. The platelet count was not monitored following home-therapy. The change in platelet count $30 \mathrm{~min}$ post-infusion correlated inversely with the dose of HYATE: $C$ given $(r=-0.64, p=0.002)$. Variation in post-infusion sampling interval probably accounts for the failure of earlier studies to discern a dose relationship, since the effect of HYATE:C on the platelet count is usually very transient $(2-4,8)$. A dose-relationship might be expected, since the effect is caused by residual porcine von Willebrand factor in the concentrate $(18,19)$.

The frequency with which infusion of HYATE:C causes a significant fall in platelet count may have been overestimated in the past since platelets tend only to be monitored during intensive replacement therapy (8), the median dose monitored for platelet count being $96 \mathrm{U} / \mathrm{kg}$. Although thrombocytopenia was occasionally observed, this usually followed intensive replacement therapy for surgery or severe bleeding and severe thrombocytopenia was rare, as reported by others (2-4, 7-9). It is unlikely that the small doses of HYATE:C used for regular replacement therapy would have any significant effect on the platelet count, since the effect is so clearly dose-related.

This survey shows that although most clinicians still reserve porcine VIIIC for the treatment of more serious bleeding episodes, it has a place as first-line therapy in patients with little of no anamnestic response to HYATE: $C$ whose current inhibitor titres suggest that porcine VIIIC would be more effective than other treatment modalities. A subgroup of inhibitor patients may be treated routinely, without side effects, for months or years. Candidates for such an approach may be identified by their low or absent pretreatment cross-reactivity, and by the absence of idiosyncratic reactions or anamnesis to HYATE:C during the first few weeks or months of regular replacement therapy.

\section{Acknowledgements}

We would like to thank the following for contributing data to this study: A. Aronstam, Treloar Haemophilia Centre, England. L. Aledort, Mount Sinai Hospital, New York, NY, USA. T. Baglin, Addenbrooks Hospital, Cambridge, UK. B. Bell, EmoryEggleston, Atlanta, GA, USA. L. Bemiller; Naval Hospital, San Diego, CA, USA. E. Briët, Akademisch Ziekenhouis, Leiden, Holland. R. Bona. St Frances Hospital. Hartford, Connecticut, USA. G. Buchanan, Children's Medical Center; Dallas, TX. USA. B. Bybee, Mountain States, UT, USA. N. Ciavarella, Haemophilia Centre, Bari, Italy. B. Colvin, Royal London Hospital, Whitechapel, London, UK. M. Damiano, Univ. Of Arizona Health Centrer; Tucson, AZ, USA. J. Davies, University of Miami, FL, SA. R. Francesco, St Bortolo Hospital, Vicenza, Italy. E. Fressinaud, Angers, France. H. 
Fukui, Medical University, Kashihara City, Japan. D. Green, Northwestern University, Chicago, IL, USA. I. Gribble, Montoya HC, Univ. of New Mexico, NM, USA. W. Hamna, East Tennessee Comp. Hemophilia Center, Knoxville, TN, USA. H. Hambley, Kings College Hospital, London, UK. M. Hilgartner; New York Hospital, New York, NY, USA. M. Inwood, South W. Ontario Region Haem. Prog. London, Ontario, Canada. R. Janco, Vanderbilt Univ., Nashville, TN, USA. H. Joist, St Louis, University Med. Center; St Louis, MO, USA. P. Jones, Royal Victoria Hospital, Newcastle, UK. C. Kasper; Orthopaedic Hospiral of Los Angeles, Los Angeles, CA, USA. P. Kernoff, Royal Free Hospital and Medical School, London, UK. C. Kisker, Great Plains Haemophilia Center, USA. C. Krill, Children's Hospital of MI, Detroit, Michigan, USA. J. N. Lozier; Univ. of North Carolina at Chapel Hill, NC, USA. D. Mahoney, Baylor College of Medicine, Houston, TX, USA. P. Mannucci, A. Bianchi Bonomi Haemophilia Centre, Milan, Italy. E. Mauser Bunschoten, Van Kreveld Klinic, Bilthoven, Holland. B. McVerry, St James Hospital, Leeds, UK. V. Mitchel, Leicester Royal Infirmary, Leicester; UK. S. Month, Oakland Kaiser; Oakland, CA, USA. I. Olsen, Rochester; NY, USA. R. Parmley, S. Texas Haem. Comp. Clinic, Texas, USA. F. Preston, Royal Hallamshire Hospital, Sheffield, UK. H. Roberts, Univ. of N. Carolina at Chapel Hill, NC, USA. M. Sahud, Merrit Peralta, San Francisco, CA, USA. E. Santagostino, A. Bianchi Bonomi Haemophilia Centre, Milan, Italy. C. Sedano, Hospital Valdecilla, Barcelona, Spain. R. Smith, Southwestern Medical Center, Dallas, TX, USA. D. Cochin, Paris, France. A. Street, Alfred Hospital, Victoria, Australia. J. Sweeney, Haemophilia Center of West New York, New York, NY, USA. K. T. Royal Children's Hospital, Melbourne, Australia. I. Teitel, St Michaels Hospital, Toronto, Ontario, Canada. M. Telfer, Michael Reese Hospital, Chicago, IL, USA. F. Verroust, La Queue Les Yvelines, France. A. Yoshioka, Nara Medical University, Kashihara City, Japan.

\section{References}

1. Middleton S: Polyelectrolytes and preparation of factor VIII:C. In: Unresolved problems in haemophilia. Forbes $C P$. Lowe $G D$ (eds.). MTP Press, Lancaster 1982; pp.109-20. 2. Kernoff PBA. Thomas ND, Lilley PA: Clinical experience with polyelectrolyte-fractionated porcine FVIII concentrate in the treatment of haemophiliacs with antibodies to factor VIII. Blood 1984: 63:31-4l.

3. Gatti L. Mannucci PM: Use of porcine fac- tor VIII in the management of seventeen patients with FVIII antibodies. T/homb Haemost 1984; 51: 379-92.

4. Brettler DB. Forsberg A, Levine PH, Buttler $\mathrm{DB}$, Forsberg A, Levine PH, Aledort LM, Hilgartner MW, Kasper CK, Lusher JM, McMillan $\mathrm{C}$, Roberts $\mathrm{H}$ : The use of porcine factor VIII:C in the treatment of patients with inhibitor antibodies to VIII:C: a multicenter US trial. Arch Imrn Med 1989; 149: 
1381-5.

5. Macfarlane RG, Biggs R, Bidwell E: Bovine antihaemophilic globulin for the treatment of haemophilia. Lancet 1954; $i$ : 316-21.

6. Bennet B, Ratnoff WD: Immunological relationships of antihaemophilic factor of different species detected by specific human and rabbit antibodies. Proc Soc Exp Biol Med 1973; 143: 701-6.

7. Morrison AE, Ludlam CA, Kessler C: Use of porcine factor VIII in the treatment of patients with acquired hemophilia. Blood 1993; 81 (6): 1513-20.

8. Gringeri A, Santagostino E, Tradati F, Giangrande PLF, Mannucci PM: Adverse effects of treatment with porcine FVIII. Thromb Haemost 1991; 65: 245-7.

9. Fukui H, Yoshioka A, Shima M, Mori K, Yorifuji H, Terada S, Morichika S: Multicenter clinical trial of a highly purified porcine factor VIII concentrate (MTI-9002[HYATE:C]) in haemophilia A patients with inhibitors. Japanese J Thrombosis and Hamostasis 1991; $2(6): 487-500$

10. Erskine JG, Davidson JF: Anaphylactic reaction to low-molecular weight porcine factor VIII concentrates. Br Med J 1981; 282: $201 /-2$.

11. Hay CRM, Laurian $Y$, Verroust F, Preston FE, Kernoff PBA: Induction of immune-tolerance in patients with haemophilia $A$ and inhibitors treated with porcine FVIII:C by home therapy. Blood 1900; 76: 882-6.

12. Kernoff PBA: The clinical use of porcine factor VIII. In: Recent advances in haemophilia care. Kasper $K C$ (ed). Alan R Liss Inc 1990; $p p$ 47-56.
13. Kasper CK, Aledorf LM, Counts RB, Edson JR, Frantoni JC. Green D. Hampton JR, Hilgartner MW, Lazerson J, Levine PH, McMillan CW, Pool JG, Shapiro SS, Shulman NR. Van Eys J: A more uniform measurement of factor VIII inhibitors. T/romb Diath Haemorrh 1975; 34: 869-72.

14. Lozier JN, Mannucci PM, Kasper CK, Teitel JM, Hay CRM: The use of porcine factor VIII for surgical procedures in haemophilia A patients with inhibitors. Seminars in Haematology 1993; 30 (2): suppl /.

15. Fiks-Sigaud M, Bendelac L, Parquet $A$, Verroust F. Torchet MF, Berthier AM,

Fressinaud E, Guerois C, Aillaud MF. Boneu B. Derlon A, Subtil E, Bertrand MA, Borg JY, Laurian Y: Comparison of anti-porcine factor VIII inhibitor levels in 63 patients with severe haemophilia A. A French multicentric study. Vox Sang 1993: 64: 210-4.

16. Leyva WH, Knutson AP. Joist HJ:

Disappearance of a high response factor VIII inhibitor in a haemophiliac with AIDS. Am .I Clin Pathol 1099; 89:414-6.

17. Ragni MV, Bontempo FA, Lewis JH: Disappearance of inhibitor to factor VIII in HIV-infected hemophiliacs with progression to AIDS or severe ARC. Transfusion 1989: 29: 447-51.

18. Kernoff PBA: The FVIII-related antigen and antibodies to FVIII. MD Thesis, University of London, 1974.

19. Altieri DC, Capitanio AM, Mannucci PM: Von Willebrand factor contaminating porcine FVIII concentrate (HYATE:C) causes platelet aggregation. Brit J Hacmatol 1986; 63: 703-11. 


\title{
Home treatment with recombinant activated factor VII in patients with factor VIII inhibitors: the advantages of early intervention
}

\author{
Santagostino E, Gringeri A, Mannucci PM. \\ Angelo Bianchi Bonomi Haemophilia and Thrombosis Centre, \\ IRCCS Maggiore Hospital and University of Milan, Italy.
}

British Joumal of Haematology 104; 22-26, 1999 


\section{Summary}

To evaluate the feasibility, efficacy and safety of home treatment with rFVIIa 10 inhibitor patients (all haemophiliacs except one acquired post-partum) self-administered up to four doses of $90 \mu \mathrm{g} / \mathrm{kg}$ rFVIla every $3 \pm 1 \mathrm{hrs}$. The response was rated by the patient as effective (haemorrhage stopped or decreased substantially), partially effective (reduced) or ineffective (unchanged or worsened). Forty-five haemarthroses and 8 haematomas were treated within a median time of $1.0 \mathrm{hr}$. (range 0.3-11.9) since the onset of bleeding, with a median of two rFVIla doses per course (range 14). rFVIIa was effective in 42 episodes (79\%), partially effective in $6(11 \%)$ and failed in $5(10 \%)$. Compared with partially effective and ineffective treatments, effective treatments started earlier (median time: $0.6 \mathrm{vs} 2.7 \mathrm{hrs}, \mathrm{p}=0.02$ ) and required a smaller number of doses (median: 1.5 is $3, p=0.007$ ). The risk of a partially effective or ineffective treatment was smaller for treatments started within $6 \mathrm{hrs}$. since the onset of bleeding than for those which started later (OR: 0.24, 95\% Cl: 0.09-0.63). Mild side effects were reported only after $3 / 113$ self-infusions (2.6\%). Early home treatment with rFVIIa is safe, feasible and effective, inducing and maintaining haemostasis with a small number of doses.

\section{Introduction}

The development of inhibitor alloantibodies to factor VIII (FVIII) is a major complication in the management of haemophilia A, occurring in $25-50 \%$ of severely affected patients (Bray et al, 1994; Lusher et al, 1993; Addiego et al, 1993). Even though inhibitors disappear spontaneously in approximately one third of cases, approximately half of the inhibitors reach high titres and persist unless immunotolerance is successfully induced (Bray et al, 1994; Lusher et $a l, 1993$ ). Patients without haemophilia may also develop autoantibodies to FVIII. Haemostatic treatments used in patients with high responding inhibitors include porcine FVIII and FVIII bypassing agents, such as prothrombin complex concentrate (PCC) or activated PCC (APCC), and, more recently, recombinant activated FVII (rFVIIa). Treatment with porcine FVIII requires monitoring of FVIII plasma levels and is sometime associated with thrombocytopenia and allergic reactions (Gringeri et al, 1991). Although home therapy with porcine FVIII has been successfully used in selected patients (Hay et $a l, 1996$ ), this approach cannot be a feasible and safe alternative for the majority of inhibitor patients. PCC and aPCC have been widely used as first-line agents in high-responding haemophiliacs, being effective in approximately $50-65 \%$ of bleeding episodes (Lusher et al, 1980). However, these products are associated with an increased risk of thrombotic complications (Schimpf et al, 1982). rFVIIa is a new bypassing agent recently evaluated in compassionate use and investigational 
studies (Ingerslev et al, 1996; Lusher et al, 1998c). rFVIIa appears to be effective in 60-90\% of treatment courses encompassing different types of haemorrhages and surgical procedures (Ingerslev et al, 1996; Lusher et al, 1998c). Its mode of action by initiating haemostasis only at the site of tissue injury should minimize systemic activation of coagulation, as demonstrated by a good safety record with respect to thromboembolic events (Hedner \& Glazer, 1992). Other advantages of rFVIIa include viral safety, no anamnestic response, small infusion volumes and short infusion times. The main disadvantages of rFVIIa are its short half-life necessitating repeated infusions at short time intervals and the current paucity of data on optimal dosage and number of doses required. In this study the efficacy, feasibility and safety of a regimen based upon early home treatment with rFVIIa of acute haemorrhages of mild to moderate severity, was evaluated in high titre inhibitor patients.

\section{Methods}

Study Design and Patients. This open uncontrolled trial was designed for early self-treatment of patients with high titre inhibitors using fixed doses of rFVIIa (Novoseven, Novo Nordisk, Denmark) at home. Eligible patients were haemophiliacs with high responding inhibitors (historical inhibitor peak $>10 \mathrm{BU} / \mathrm{ml}$ ) or patients with high titre, acquired anti-FVIII antibodies $(>10 \mathrm{BU} / \mathrm{ml})$. To be enrolled patients had to have already received at least one treatment course with rFVIIa in the hospital without side effects. Patients were also selected on the basis of adequate venous access, ability in self-infusion, capability of assessing the response to therapy and accuracy in reporting side effects. Children with inhibitor could enter the study if the caregivers met the inclusion criteria. Eligible bleeding episodes were mild/moderate haemorrhages, either spontaneous or associated with trauma, whereas patients were encouraged to come to the hospital to treat limb- or life-threatening bleeding episodes. Patients (or caregivers) were recommended to start rFVIla treatment as soon as they experienced the early symptoms of bleeding. All information concerning the type and severity of bleeding, the time period between the occurrence of bleeding and initiation of treatment, timing of rFVIIa infusions, efficacy assessment following each infusion and at the end of treatment course and side effects had to be carefully recorded by patients in the special data collection form. Haemorrhages into target joints, defined as those experiencing frequent bleeds with progressive arthropathy and synovitis, had also to be recorded. No laboratory monitoring was performed.

Home Treatment Regimen. The time between the onset of bleeding and the first rFVIIa infusion had to be less than 12 hours. No other haemostatic drug could be used before or during rFVIIa treatment. Analgesic and/or non steroid anti-inflamma- 
tory drugs could be used and were recorded. rFVIIa was injected at the dose of 90 $\mu \mathrm{g} / \mathrm{Kg}$ b.w. every $3 \pm 1$ hours with up to 4 infusions per bleeding episode. Three hours after each infusion, patients were required to assess the response to treatment and to self-administer a further dose if the response was judged ineffective or partially effective. It was recommended to stop treatment if one of the followings occurred: achievement of an effective response, or two consecutive infusions rated as ineffective.

Efficacy Assessment. The response to rFVIla was defined on the basis of patients' subjective judgement. The degree of severity of the bleeding episode was reported by the patient on a numeric scale (from 0 : very mild, to 4 : extremely severe) before starting treatment. The response to treatment was defined as follow: effective if a definite relief of pain, swelling and mobility occurred, suggesting that haemorrhage had stopped or decreased substantially; partially effective if an improvement in pain, swelling and mobility was perceived, suggesting a slowing of bleeding; ineffective if no relief of symptoms occurred and haemorrhage continued or worsened. Patients were asked to rate the response to rFVIIa three hours after each dose and at the end of each treatment course.

Statistical Analysis. For efficacy analysis, ineffective treatment courses and recurrences of bleeding at the same site within 48 hours since the first rFVIIa infusion were considered treatment failures. Student's t-test and analysis of variance were used to compare different parameters among types of haemorrhages or timing of treatment start. Chi-square and Fisher's exact tests were used to compare the response rates among different types of haemorrhages or different timing of treatment start.

\section{Results}

Among 20 patients with high responding inhibitors regularly followed up at the Haemophilia and Thrombosis Centre in Milan, 10 were enrolled in the trial because they met the inclusion criteria. All patients had severe haemophilia A, but a woman had post-partum acquired inhibitor. The median age at enrolment was 31 years (range: 3-62). The median age at the time of first inhibitor detection was 13 years (range: 2-61). Historical inhibitor peaks ranged from 16 to $16,000 \mathrm{BU} / \mathrm{ml}$. The median inhibitor titre at the time of study entry was $18 \mathrm{BU} / \mathrm{ml}$ (range: $1-870$ ).

From February 1997 to May 1998, overall 59 bleeding episodes were treated at home with a median number of treatment courses per patient of 3 (range: 1-16). Overall $697 \mathrm{mg}$ of rFVIIa (median: $48 \mathrm{mg} /$ patient, range: $4.8-174$ ) were employed in a total of 113 self-infusions (median: 8 infusions/patient, range: 1-29), all considered for safety evaluation. rFVIIa infusions were administered by caregivers in the 
only child enrolled in the study. No patient required hospital admission nor experienced technical problems related to factor injections. Mild side effects occurred after $3 / 113$ infusions ( $2.6 \%$ ), all reported by the same patient who complained of a transient increase of pain at the bleeding site after $3 / 29 \mathrm{rFVIIa}$ injections.

Fifty-three treatment courses $(90 \%)$ were evaluable for efficacy (Table 1). The median amount of rFVIla administered per treatment course was $12.0 \mathrm{mg}$ (range: $4.8-28.8$ ). The median number of rFVIla doses per treatment course was 2 and no statistically significant difference was found in the number of doses required to treat the different types of

Table 1. Time from the onset of bleeding to the beginning of treatment and number of doses per treatment course in 53 bleeding episodes treated at home with rFVIla.

$\begin{array}{lrcc}\text { Bleeding episode } & \text { No. } & \begin{array}{l}\text { Hours from the onset of } \\ \text { bleeding to the first rFVlla } \\ \text { dose, median (range) }\end{array} & \begin{array}{l}\text { No. of } \\ \text { rFVlla doses } \\ \text { median (range) }\end{array} \\ \text { Haemarthroses } & 45(85 \%) & 0.8(0.3-11.9) & 2(1-4) \\ \text { in non-target joints } & 21(40 \%) & 0.5(0.3-11.8) & 1(1-3) \\ \text { in target joints } & 24(45 \%) & 1.25(0.3-11.9) & 2(1-4) \\ \text { Haematomas } & 8(15 \%) & 5.5(0.3-11.8) & 1(1-4) \\ \text { Spontaneous haemorrhage } & 41(77 \%) & 0.5(0.3-11.9) & 2(1-4) \\ \text { Post-traumatic haemorrhage } & 12(23 \%) & 5.5(0.3-11.8) & 3(1-4) \\ \text { Total } & 53(100 \%) & 1(0.3-11.9) & 2(1-4)\end{array}$

bleeding episodes (Table 1). The time spent from the onset of bleeding to the first rFVIIa injection is reported in Table 1: haematomas and post-traumatic haemorrhages were treated significantly later than the other episodes, whereas the time to the beginning of treatment was not significantly different between target and non target joint bleeds. Efficacy data concerning 53 treatment courses are reported in Table 2 , showing that on the whole home treatment with rFVIla was effective in $42(79 \%)$ bleeding episodes and partially effective in $6(11 \%)$. Treatment failures occurred in 5 episodes ( $10 \%$ ). In particular, rFVIla therapy was judged ineffective in 3 haemorrhages that occurred into target joints, whereas the remaining two failures were due to recurrent joint haemorrhages within 48 hours from the first rFVIIa injection (one of these recurrent haemorrhages was into a target joint). Both bleeding recurrencies were treated with APCC. No statistically significant difference was observed in the responses to rFVIIa according to the different types of bleeding episodes. Effective treatment courses started significantly earlier and required a lower number of rFVIIa doses compared to courses with partially effective responses or treatment failures, as shown in Table 3. In particular, the risk of having a partially effective outcome or a treatment failure was significantly lower for courses started within 6 hours from the onset of bleeding than for those started after 6 hours (odds ratio: $0.24,95 \%$ confidence interval: $0.09-0.63$ ). 


\section{Discussion}

It is generally agreed that the early treatment of bleeding in haemophilia, as allowed by self-administration at home, results in a high success rate. However, this ap-proach has not been widely adopted in patients with inhibitors, because this complication renders treatment more difficult and that available products were not safe enough for home infusion. rFVIIa looks promising for home therapy of mild to moderate haemorrhages in inhibitor patients, thanks to its safety profile and the absence of an anamnestic response. This study, designed to evaluate the efficacy and feasibility of this therapeutic modality, employed a regimen based upon fixed doses of rFVIIa injected at regular time intervals, chosen to simplify patient selfadministration at home. The dosage and the time intervals of

Table 2. Response to home treatment with rFVIla in 53 bleeding episodes.
Bleeding episode

Haemarthroses

in non target joints

in target joints

Haematomas

Spontaneous haemorrhage

Post-traumatic haemorrhage

Total
No.

45

21

24

8

41

12

53
Response to rFVlla treatment Effective Partially effective Failure

\begin{tabular}{|c|c|c|}
\hline $36(80 \%)$ & $4 \quad(9 \%)$ & $5(11 \%)$ \\
\hline $18(86 \%)$ & $2(9 \%)$ & $1 * \quad(5 \%)$ \\
\hline $18(75 \%)$ & $2(8 \%)$ & $4^{\wedge}(17 \%)$ \\
\hline $6(75 \%)$ & $2(25 \%)$ & - \\
\hline $34(83 \%)$ & $3(7 \%)$ & $4(10 \%)$ \\
\hline $8(67 \%)$ & $3(25 \%)$ & $1 \quad(8 \%)$ \\
\hline $42(79 \%)$ & $6(11 \%)$ & $5(10 \%)$ \\
\hline
\end{tabular}

* bleeding recurrency at the same site within 48 hours of the first rFVlla injection.

" 3 ineffective treatment courses and 1 bleeding recurrency at the same site within 48 hours of the first dose.

Table 3. Time from the onset of bleeding to the beginning of treatment and number of rFVlla doses per treatment course in 42 effective treatment courses compared to 11 courses with partially effective outcome or treatment failure.

\begin{tabular}{|c|c|c|c|}
\hline Treatment outcome & No. & $\begin{array}{l}\text { Hours from the onset } \\
\text { of bleeding to the first rfVila } \\
\text { dose, median (range) }\end{array}$ & $\begin{array}{l}\text { No, of rFVlla } \\
\text { doses, median } \\
\text { (range) }\end{array}$ \\
\hline Effective & $42(79 \%)$ & $0.6(0.3-11.8)$ & $1.5(1-4)$ \\
\hline Partially effective or failure & $11(21 \%)$ & $2.7(0.3-11.9)$ & $3(1-4)$ \\
\hline$p$ value & & 0.02 & 0.007 \\
\hline
\end{tabular}

injections were chosen

on the basis of data from pharmacokinetic studies of rFVIIa in humans (Hedner, 1996).

Patient reliability and compliance were essential prerequisites for enrolment in this study, because early treatment was strongly recommended and efficacy assessment was based solely on patient judgement. Over 15 months, 59 bleeding episodes, mostly haemarthroses, were managed at home with a small number of rFVIIa infusions by 10 inhibitor patients with no need for hospitalisation. The feasibility and safety of home treatment with rFVIla were excellent. Efficacy was also satisfactory with an effective control of 
haemorrhage in about $80 \%$ of treated episodes. Recurrency at the same bleeding site occurred within 48 hours since the first rFVIla dose in $3.8 \%$ of treatment courses. Two rFVIla infusions were sufficient to achieve a successful outcome in more than half of the bleeding episodes, so that most patients recovered within 6 hours from the first dose. Interestingly, the rate of effective responses as well as the number of doses used was similar in treatment courses for target and non-target joint bleeds, although four of the five failures were observed after treatment of target joint bleeds. The size of the study is inadequate to detect differences among different sites of haemarthroses and between haemarthroses and haematomas.

There is little detailed information about the use of rFVIIa as home therapy, because the results of studies currently undergoing in the USA (Key, 1997), France (Laurian et al, 1998) and Denmark (Ingerslev et al, 1998) have been only published in abstract forms. The preliminary results of the US rFVIIa Home Therapy Study (Key, 1997), which is similar to this study, in terms of treatment regimen and efficacy evaluation criteria, give a rate of effective responses of $92 \%$. Differences in type and severity of treated episodes or the use in the US study of a consolidation dose of rFVIIa after successful outcome might account for the slight difference in success rate between the two studies. In the different home therapy studies, the number of doses required to stop bleeding is quite low, the median value being lower than 2.0 in the Danish (Ingerslev et al, 1998) and our studies, and equal to 2.2 in the US study (Key, 1997) and 2.9 in the French one (Laurian et al, 1998). A recent report (Key \& Laurian, 1998) comparing the US and French studies failed to demonstrate any significant reduction in bleeding recurrence using rFVIIa for consolidation of successful outcomes. The recurrence rate at 48 hours observed by us without consolidation doses $(3.8 \%)$ was lower than that observed in the French study (Key \& Laurian, 1998) (6.1\% using a consolidation dose and $8.2 \%$ without it) and similar to the recurrence rate at 24 hours reported in the US study which uses a consolidation dose (Key \& Laurian, 1998) (4.9\%). Therefore, the results of our study support the views that additional injections may not be necessary to maintain haemostasis after a successful response in home treatment with rFVIIa.

Recently, many efforts have been made to collect data supporting the hypothesis that early treatment with rFVIla could produce a better outcome. Lusher (1998a) analysed the data of three different studies (Lusher et al, 1998c; Key, 1997; Lusher et al, 1998b) in which muscle haematomas were treated with rFVIla allowing a comparison between early versus late intervention. These studies were not strictly comparable in terms of dosages used, however preliminary results strengthen the views that a greater success rate with fewer doses can be achieved with early inter- 
vention. Our study clearly demonstrates the positive correlation existing between effective outcome and early start of rFVIIa therapy. The probability of achieving an effective response was 4 times greater in treatments started within 6 hours since the onset of bleeding than in those started later. The mean cost of a single treatment course with rFVIla in this study was 8,746 \$. Considering that the cost of APCC treatment with two doses per bleeding episode is about $10,000 \$$ in Italy, home treatment of mild/moderate haemorrhages with rFVIIa appears no more expensive than treatment with APCC.

In conclusion, our experience with rFVIIa for home treatment of haemarthroses and haematomas was successful in terms of feasibility, efficacy and safety confirming that selected inhibitor patients, well-instructed and compliant, may benefit from early self-administration of $\mathrm{rFVIIa}$ in the home setting. In these cases rFVIIa may represent a safe first line treatment requiring a small number of doses and allowing a reduction in the number of days spent in hospital and consequently in the related cost.

\section{References}

1. Addiego J, Kasper C, Abildgaard CF, Hilgartner M, Lusher J, Glader B, Aledort L: (1993) Frequency of inhibitor development in haemophiliacs treated with low purity factor VIII. Lancet, 342, 462-464.

2. Bray GL, Gomperts ED, Courter S, Gruppo R, Gordon EM, Manco-Johnson M, Shapiro A, Scheibel E, White G, Lee M Recombinate Study Group: (1994) A multicenter study of recombinant factor VIII (Recombinate): safety, efficacy and inhibitor risk in previously untreated patients with hemophilia A. Blood, 83, 2428-2435.

3. Gringeri A, Santagostino E, Tradati F, Giangrande PLF, Mannucci PM: (1991) Adverse effects of treatment with porcine FVIII. Thrombosis and Haemostasis, 65, 245 247.

4. Hay CRM, Lozier JN, Lee CA, Laffan M, Tradati F, Santagostino E, Ciavarella N.
Schiavoni M, Fukui H, Yoshioka A, Teitel J, Mannucci PM, Kasper CK: (1996) Safety profile of porcine factor VIII and its use as hospital and home-therapy for patients with haemophilia A and inhibitors: the results of an international survey. Thrombosis and Haemostasis, 75, 25-29.

5. Hedner U, Glazer S: (1992) Management of hemophilia patients with inhibitors. Hematology/Oncology Clinics of North America, 6, 1035-1046.

6. Hedner U: (1996) Dosing and monitoring Novoseven treatment. Hacmostasis. 26.

(Suppl. 1). 102-108.

7. Ingerslev J, Freidman D, Gastineau D, Gilchrist G, Johnsson H, Lucas G, McPherson J, Preston E, Scheibel E, Shuman M: (1996) Major surgery in haemophilic patients with inhibitors using recombinant factor VIIa. Haemostasis. 26 , (Stuppl. 1). 118-123. 
8. Ingerslev J. Thykjaer H. Kudsk Jensen $\mathrm{O}$. Fredberg U: (1998) Home treatment with recombinant activated factor VII: results from one centre. Blood Coagulation and Fibrinolysis. 9. (Suppl.1).S107-S/10).

9. Key NS for the US rFVIla Home Therapy Study Group: (1997) Efficacy of recombinant factor VIIa (rFVIIa) when administered in the home to control joint, muscle and mucocutaneous bleeds in hemophiliacs with inhibitors. Thrombosis and Haemostasis, Iume. (Suppl. I). 51. abstract PS-206.

10. Key NS, Laurian Y for the US rFVIla Home Therapy and the French Nosepac Study Groups: (1998) Comparison of two studies on the use of Novoseven in home treatment of mild to moderate bleeding episodes in haemophiliacs with inhibitors. Hacmophilia, 4, 241, abstract 342.

11. Laurian Y, Goudemand J, Negrier C. Vicariot M, Marques-Verdier A. Fonlupt J. Gaillard S. Fressinaud E, Dirat G, Sultan Y, Faradji A,

Clayessens S, Guerois C. Peyney J, Bertrand MA, Digy J.P: (1998) Use of recombinant activated factor VII as first-line therapy for bleeding episodes in haemophiliacs with factor VIII or IX inhibitors (NOSEPAC study). Blood

Coagulation and Fibrinolysis, 9. (Suppl.1). S155SI56.

12. Lusher JM, Shapiro SS, Palascak JE, Rao AV. Levine PH. Blatt PM, for the Hemophilia Study Group: (1980) Efficacy of prothrombin-complex concentrates in haemophiliacs with antibodies to factor VIII: a multicenter therapeutic trial. New England Joumal of Medicine, 303, 421-425. 13. Lusher JM, Arkin S, Abildgaard CF, Schwartz RS. and the Kogenate Previously Untreated Patient Study Group: (1993) Recombinant factor VIII for the treatment of previously untreated patients with haemophilia A. New England Iournal of Medicine, 328. 453-459.

14. Lusher JM: (1998a) Recombinant activated factor VII for treatment of intramuscular haemorrhages: a comparison of early versus late treatment. Blood Coagulation and Fibrinolysis, 9. (Suppl. 1).S1/1-S1/4

15. Lusher JM, Ingerslev J, Roberts $H$, Hedner, U: (1998b) Clinical experience with recombinant factor VIIa. Blood Coagulation and Fibrinolysis. 9.119-128.

16. Lusher JM. Roberts HR, Davignon G, Joist JH, Smith H, Shapiro A, and the rFVIla Study Group: (1998c) A randomised double-blind comparison of two dosage levels of recombinant factor VIIa in the treatment of joint, muscle and mucocutaneous haemorrhages in persons with haemophilia $A$ and $B$, with and without inhibitors. Haemophilia. in press. 17. Schimpf K, Zeltsch C. Zeltsch P: (1982) Myocardial infarction complicating activated prothrombin complex concentrate substitution in a patient with haemophilia A. Lancet; $i i$, 1043. 


\section{Chapter 6}

Summary and prospectives 
$\mathrm{R}$ eplacement treatment is necessary for hemophiliacs throughout their life-spans and the complications associated with the use of the concentrates have an impressive impact on the clinical status of hemophiliacs. At this time, about $30 \%$ of Italian patients with severe hemophilia are HIV-infected (Ghirardini A. et al. National Haemophilia Registry, Italian Group for Congenital Coagulopathies: 1996 Report) and the prevalence is higher if only the adult population is considered. Almost all adult hemophiliacs are chronically infected with HCV. These serious blood-borne infections have not affected hemophilic children who have received safer replacement therapy. However, the occurrence of inhibitors is still the major complication for these children.

The work presented in this thesis was based on the experience at our Center with the clinical management of hemophilia and its heterogeneous complications and on research into this complex, interdisciplinary disease.

\section{Chronic Hepatitis C}

Currently, in many Hemophilia Centers the adult cohort mainly consists of patients with chronic hepatitis $C$ but not infected with HIV, at high risk of liver-related morbidity and mortality. Antiviral treatment of $\mathrm{HCV}$ infection might be of clinical importance in this population. Our experience with interferon alpha therapy in hemophiliacs with chronic hepatitis C (Chapter 2) gave disappointingly low rates (13\%) of sustained virologic responses, in spite of the prolongation of interferon treatment ( $3 \mathrm{MU}$ three times a week) for up to 12 months. In agreement with the findings in other studies (Telfer et al. Thromb Haemost 1995; 74: 1259), we have identified epidemiologic and virologic factors in hemophiliacs that are associated with poor responsiveness, these being long duration of HCV infection, HCV genotype 1 and high viremia levels. These results have prompted a search for other therapeutic agents, such as ribavirine and amantadine. The results of a recent randomized trial in nonhemophilic patients (Reichard $O$. ct al. Lancet 1998; 351: 83) have indicated that combination treatment with interferon and oral ribavirin may offer a better prospect of sustained virological response than interferon alone. We have employed the combined treatment with interferon/ribavirin for hemophiliacs previously unresponsive to interferon monotherapy and the encouraging results of this study, too preliminary to be included in this thesis, provide the basis for using this combined therapy for hemophiliacs not previously exposed to interferon.

The identification of noninvasive markers predicting the severity of the disease among hemophiliacs at risk for end-stage liver disease, indicating those most likely to benefit from treatment, is still a research priority. Given the natural history of chronic hepatitis, an increasing number of hemophiliacs will become candidates for liver transplantation. In these patients transplantation will allow correction of the underlying coagulation 
defect, because both factor VIII and IX are synthesized by hepatocytes. The association of $\mathrm{HCV}$ infection with a number of extrahepatic manifestations has recently changed the prospective of the natural history of the disease. In this framework, the detection of cryoglobulinemia in about one third of our HCV-infected hemophiliacs (Chapter 2) raises concerns about the clinical significance of this complication. Interestingly, none of the patients had clinical signs of systemic vasculitis. Our data demonstrate that the risk of developing cryoglobulins increases with the duration of $\mathrm{HCV}$ infection, but the relevance of this HCV-related disorder still has to be established. A large prospective surveillance study is underway to address this issue, particularly with respect to the possible, long-term evolution towards non-Hodgkin lymphoma, currently being investigated for its association with $\mathrm{HCV}$ infection and cryoglobulinemia.

\section{HIV infection}

Prolonged survival of HIV-infected hemophiliacs has been observed in several series (Phillips AN. et al. Jama 1992; 268: 2662). In our cohon (Chapter 3), 10 years after seroconversion the cumulative survival was $76 \%$ and AIDS-free survival was $71 \%$. Interestingly, HIV infection was more prevalent and associated with shorter survival in patients with hemophilia $\mathrm{B}$, according to the national data provided by the Registry (Schinaia N. et al. Thromb Haemost 1994; 72: 33). Several factors, that influence positively survival and AIDS-free survival in hemophiliacs, have been recognised such as young age and high CD4 cell counts at seroconversion. Currently, the introduction of highly active anti-retroviral therapy (HAART) has further changed the figures for AIDS progression and also for survival. Nevertheless, limited group of patients have never required antiviral treatment to maintain normal CD4 lymphocyte counts. Patients with non-progressive HIV infection offer a unique model to study HIV pathogenesis. Long-term non-progressors (LTNPs) may be a heterogeneous group of patients. A strong immune response against HIV proteins by cytotoxic $T$ lymphocytes and anti-HIV neutralizing antibodies, as well as low viral replication, have been reported in LTNPs from various risk categories by several authors (Cao Y. et al. N Eng J Med 1995; 332:201, Pantaleo G. et al. N Eng J Med 1995; 332: 209). At present, the nature of non-progressive HIV infection still remains elusive. Our study of a homogeneous group of hemophilic LTNPs (Chapter 3) showed that low HIV loads and low replication in peripheral blood (measured as proviral DNA in PBMCs and HIV-RNA in plasma and PBMCs) are the strongest correlates of non-progression. However, no absolute distinction can be made between LTNPs and progressors based exclusively on virologic parameters, supporting the view that there is a continuum between these two otherwise strikingly diverse outcomes of HIV infection. The recent discoveries concerning the suppressive effect of chemokines, produced by immune cells. on HIV replication 
(Cocchi F. et al. Science 1995: 270: 1811) and the identification of chemokine receptors as the second receptor for HIV (Feng Y. $e$ al. Science 1996; 272: 872) suggest there is a protective role of chemokines or their receptors during HIV infection. The hypothesis that protection might be related to the inability of HIV to infect target cells in the absence of the receptor is supported by the results showing homozygous mutations of the chemokine receptor in HIV-exposed but not infected individuals (Samson M. et al. Nature 1996: 382: 722). These findings have led us to study (Chapter 3) the 14 hemophiliacs of our cohort who have escaped HIV infection despite having been given a median of $166,000 \mathrm{U}$ of contaminated concentrate in the period between 1980 and 1985. None of them showed homozygous mutations in the chemokine structural gene. Nevertheless, our data showing a higher production of chemokines in HIV-exposed but not infected hemophiliacs than in unexposed controls, whether hemophiliacs or not, provides evidence on their role as initial effector components of the cellular immune response. The protective direct effect of chemokines has been demonstrated by in vitro experiments showing that supernatant from PBMCs obtained from the exposed but not infected hemophiliacs inhibited HIV infection and the inhibitory effect was abolished by anti-chemokine antibodies. These findings support ongoing research into agents mimicking chemokines and/or blocking cell chemokine receptors. Demonstration of natural resistance to HIV infection encourages study of preventive vaccines able to block viral entry and subsequent spread to cells, providing a specific cytotoxic response.

\section{Other pathogenic agents}

Even though the new generation of hemophiliacs does not have to deal with these serious viral complications, the issue of surveillance is still alive, since absolute viral safety is still not achieved. Plasma-derived products are widely used and the awareness that they still transmit B19 parvovirus (Chapter 4) raises concern about other unknown agents with similar resistance to robust viral inactivation procedures. Recombinant coagulation factors are safer with respect to transmission of conventional viral infections. The next generation of recombinant products will not be processed or formulated with human or animal proteins, thereby minimizing the risk of transmission of agents of heterologous origin and of such non-viral pathogens as prions. Even though recombinant technology has offered the promise of unlimited supply, at the moment, worldwide demand for recombinant products for hemophilia treatment far exceeds supply.

\section{Inhibitor development}

Recombinant products are currently used in developed countries for replacement for hemophilic children, who are under strict surveillance for inhibitor risk. The development of inhibitors changes the therapeutic prospective for these patients, who require 
immune tolerance treatment to eradicate antibodies and bypassing products to treat acute bleeding. Our work on the assessment of safety and efficacy of therapeutic options for high titer inhibitor patients is reported in Chapter 5. Early home treatment with recombinant FVIIa was evaluated in patients of our Center on a self-treatment regimen with fixed doses and with the patients instructed on how to assess treatment efficacy and to detect side effects. Self-administration of recombinant FVIla at home proved to be of excellent feasibility and safety and resulted in a high success rate (79\%) with a small number of doses (median 2), demonstrating the existence of a correlation between early treatment with recombinant FVIIa and effective outcome. Discordant data have been reported about the frequency and severity of side effects after the use of porcine factor VIII (Brettler DB. et al. Arch Intern Med 1989; 149: 1381, Hay CRM. et al. Blood 1990; 76: 882, Gringeri A. et al. Thromb Haemost 1991; 65: 245), making the safety of this treatment questionable. Different dose regimes and treatment modalities were employed in hospitalized patients and in the home setting, making comparison of data unreliable. An international survey (Chapter 5) was used to address this issue through retrospective data collection using a standardized questionnaire. The incidence of transfusion reactions was quantified after the use of porcine factor VIII as home infusions $(0.001 \%)$, infusions in multiply treated inpatients $(0.64 \%)$ and unselected in-patients infusions $(2.3 \%)$. The low rate of side effects observed in patients treated at home was attributable to the low doses used by this group. The common post-infusion fall in platelet counts was usually transient and was judged to be clinically insignificant. Introduction of a viral inactivation step in the manufacturing process for porcine factor VIII is foreseen in the near future to further improve the safety profile of this preparation.

The observation of development of inhibitor in two adult brothers with mild hemophilia A led us to report (Chapter 5) this rare clinical condition, characterized by an unusual behaviour in response to replacement treatment, with anamnestic inhibitor rise after exogenous factor VIII administration and satisfactory response to desmopressin, suggesting a low immunogenicity of endogenous factor VIII. DNA analysis identified a missense mutation in the factor VIII gene. Subsequent data collection from US and European Centers (Chapter 5) has detected 26 patients with mild/moderate hemophilia $A$ and inhibitors, confirming the association of this particular phenotype with relatively few missense mutations in the $\mathrm{A} 2$ and $\mathrm{C} 2$ domains.

The general characterization of anti-factor VIII inhibitors by their specific binding to epitopes mainly located in the A2 and C2 domains (Scandella D. et al. Pro Natl Acad Sci USA 1988; 85: 6152) has led to an experimental approach based upon the use of the recombinant hybrid human/porcine factor VIII molecule. This contains porcine substitutions at human epitope sites, avoiding at the same time the exposure of porcine 
neoepitopes (Lollar P. Thromb Haemost 1999; 82: 505). Furthermore, epitope mapping is the basis for the development of recombinant, human factor VIII molecules with reduced immunogenicity.

The ultimate prospective in the cure of hemophilia is gene therapy. Hemophilia A and $B$ are ideal diseases to be cured by gene therapy for several reasons, including the following: they are single-gene disorders, they require intravenous replacement treatment at frequent intervals, tight regulation of expression is probably unnecessary and tissuespecific expression is probably unimportant.

Considerable interest and enthusiasm have been generated in this research field in recent years, but formidable challeges remain. A variety of approaches have been developed, including viral and nonviral gene delivery systems and different target cells for gene expression. Adequate, sustained levels of factor VIII or IX have not been fully realized. In preclinical studies using hemophilic murine and canine models, immunogenicity resulting from the vectors and/or the new gene product has been cause for concern. Furthermore, there is at least the theoretical concern that certain viral vectors could potentially enter the germ line when administered intravenously. Recently, gene therapy trials have been started in humans with hemophilia aiming at a complete safety evaluation with careful, long-term follow-up. In addition, the issue of development of inhibitor in relation to gene therapy has to be addressed: will chronic exposure to antigen increase the risk of inhibitor or, alternatively, will it have a role to play in the treatment of patients with inhibitor? 
This work was carried out at the Angelo Bianchi Bonomi Hemophilia and Thrombosis Center of the Maggiore Hospital and University of Milan, in 1995-2000. The publication of this thesis has been financed by Istituto Sierovaccinogeno Italiano-ISI, which is gratefully acknowledged.

My deepest thanks to Prof. Pier Mannuccio Mannucci, who directed my training towards hemophilia care and clinical research. His extraordinary knowledge in these fields and his unique attitude to translate experiences and feelings into bright, sharp opinions have been fundamental for my scientific formation and even precious for my personal growth.

I owe a lot to Dr. Alessandro Gringeri with whom I have shared the professional commitments and the pleasure of friendship. Taking care of our patients in the critical years of AIDS epidemic, he taught me never to give up in front of difficulties. His never ending patience is certainly proved by the constant support received during my research as well as dealing with all sort of troubles.

Moreover, I would like to express my thanks to Prof. H.C. Hemker and Prof. S. Beguin for their encouragement and to T. Camphuisen-Engel for her kind help.

I am very grateful to all the physicians, nurses and laboratory staff working with me at the Hemophilia and Thrombosis Center and Hepatology Department for the skilful and friendy co-operation showed in the daily routine of clinic and research.

I greatly appreciate the competent collaboration of all the colleagues of the Hemophilia Centers in Italy and abroad who made possible to carry out fruitful multicentric studies.

I wish to thank Prof. Daniel Zagury for his prominent contribution to AIDS research and friendly support.

My research could not be done without the active contribute of the hemophiliacs who took part with enthusiasm and optimism to clinical trials.

Finally, I want to thank my father for his continuous encouragement and my joyful son, Ivan, who prevented me from being completely absorbed by my work. 
Elena Santagostino was born on 8th June 1962 in Milan. In 1981 she entered the School of Medicine at the University of Milan obtaining the summa cum laude Degree in Medicine in 1987. In the following years, she began her clinical and scientific education at the Haematology and Internal Medicine Departments of Maggiore Hospital and University of Milan, under the leadership of Prof. P.M. Mannucci. In 1990 she obtained the summa cum laude Postdegree in Clinical and Laboratory Haematology at the Speciality School directed by Prof. Mannucci. In 1992 she entered the Speciality School of Internal Medicine directed by Prof. Agostoni at the University of Milan obtaining the Postdegree in Internal Medicine in 1997. In 1989 she started working as research fellow in the clinical field of haemophilia in co-operation with Dr. Gringeri at the Angelo Bianchi Bonomi Haemophilia and Thrombosis Centre of Maggiore Hospital, directed by Prof. Mannucci. Since 1992, she has been working as Clinical Assistant at the above mentioned Haemophilia Centre. She has been engaged in the research concerning epidemiology, natural history and therapy of haemophilia and transfusion-transmitted diseases. Her scientific contribute is represented by studies conducted in the cohort of patients followed at the Haemophilia Centre in Milan, multicenter trials designed in co-operation with the Italian Haemophilia Centres and international clinical trials. 